\title{
GOVERNANÇA REPUBLICANA COMO VETOR PARA A INTERPRETAÇÃO DAS NORMAS DE DIREITO FINANCEIRO
}

Tese de Doutorado apresentada à Banca Examinadora da Faculdade de Direito da Universidade de São Paulo, como exigência parcial para a obtenção do título de Doutor em Direito, sob orientação do Prof. Titular Régis Fernandes de Oliveira

FACULDADE DE DIREITO DA USP SÃO PAULO 
Para minha família, Fabiana, Juliana, Henrique e Vinícius, a quem dedico todo o meu amor. 


\section{AGRADECIMENTOS}

Minha sábia avó Yedda sempre nos dizia que, de tão abençoada por Deus, ela se sentia como uma de suas preferidas. Essa lição de gratidão me faz reconhecer que sou abençoado por estar rodeado de pessoas que me inspiram a procurar melhorar sempre, um pouco a cada dia.

Agradeço a meu eterno mestre e orientador, Régis Fernandes de Oliveira, pela confiança e pelas orientações precisas quanto à direção que eu deveria tomar com a redação da tese. Meu respeito, apreço e admiração foram solidamente construídos ao longo desses mais de dez anos de convivência acadêmica.

Minha gratidão também a Luiz Antônio Guimarães Marrey, Ronaldo Augusto Bretas Marzagão e Paulo Renato Souza, exemplos de homens públicos, com quem tive o privilégio de trabalhar e receber lições diárias de competência, simplicidade e respeito. $\mathrm{O}$ apoio e a compreensão durante a execução do trabalho foram essenciais para a sua conclusão.

Também agradeço aos professores da Universidade de São Paulo, José Maurício Conti, Edmir Netto de Araújo e Valmor Slomski, que passei a considerar como amigos durante o curso.

Muito obrigado a todos os meus amigos, que de alguma forma compartilharam comigo as angústias e realizações que envolvem a elaboração de uma tese de doutorado. Agradecimento especial a Antônio Carlos Cintra do Amaral Filho, Fernando Padula, Gabriel Loretto Lochagin, Gabriela Brandão, Gilmar Ribeiro de Mello, José Augusto Moreira de Carvalho, Rafael Meira, Rubens Rizek, Sérgio Assoni Filho e Victor Fujii, que colaboraram com ideias, reflexões, artigos, críticas e sugestões. 
Meu reconhecimento também aos meus sócios no escritório, em especial ao meu tio, Eduardo, quase um pai para mim, e aos meus colegas de trabalho da Prefeitura de São Paulo, das Secretarias Estaduais de Justiça e Defesa da Cidadania, da Segurança Pública e da Educação.

Agradeço aos meus pais, que me ensinaram o valor do trabalho e da honestidade, e aos meus filhos, Juliana, Henrique e Vinícius. Confesso que a maior dificuldade para a realização deste trabalho foi privar-me por alguns preciosos momentos da companhia deles.

Por fim, minha eterna gratidão à minha esposa, Fabiana, amor da minha vida, cuja doçura, sabedoria e fortaleza são os alicerces da minha família. Sem o seu apoio e incentivo eu não teria conseguido. 


\section{RESUMO}

O mundo corporativo desenvolveu mecanismos para atenuar os conflitos de agência, decorrentes das divergências entre os interesses dos acionistas e dos gestores profissionais. A adoção de práticas de governança corporativa nas sociedades empresariais, em que o capital está pulverizado entre milhares de acionistas que não participam da gestão do negócio, impõe aos gestores um comportamento ético, pautado pela boa-fé, pela transparência, pela prestação de contas, pela eficiência e pela responsabilidade pelos atos de gestão. De outro lado, permite que os acionistas acompanhem e participem do estabelecimento das diretrizes da administração do empreendimento, sempre sob o pressuposto de que o gestor age em nome dos interesses dos proprietários da empresa. No regime republicano estabelecido pela Constituição Federal de 1988 os cidadãos são os titulares da res publica, cabendo ao gestor público a administração da coisa pública em prol dos interesses da sociedade. A gestão dos recursos públicos, regulada pelo Direito Financeiro, deve seguir rigorosamente a lógica republicana, mas neste ponto é possível identificar potenciais conflitos de agência entre os gestores públicos e os cidadãos. Com o objetivo de garantir a melhor aplicação dos escassos recursos financeiros arrecadados junto à sociedade, a Constituição Federal institucionalizou um complexo sistema de preservação do interesse público na gestão financeira estatal, sistema esse descrito neste trabalho, aqui denominado de governança republicana. Esse complexo, constituído de normas e princípios constitucionais, normas infraconstitucionais, mecanismos de controle e planejamento, além de formas de participação social, formam um sistema institucional de proteção à boa aplicação dos recursos financeiros do Estado e devem servir aos aplicadores do direito como vetor para a interpretação das normas de Direito Financeiro.

Palavras-chave: Direito Financeiro, governança corporativa, governança no setor público, finanças públicas, transparência, accountability, princípios da administração, gestão de recursos públicos. 


\begin{abstract}
The corporate world developed mechanisms to lessen agency conflicts due to divergences between shareholders' and professional managers' interests. The adoption of corporate governing practices in corporate businesses (where the capital is spread out among thousands of shareholders, who do not participate in the administration of the business) requires an ethical behavior from the managers; this ethical behavior should be guided by good-faith, transparency, accountability, efficiency and responsibility for the administrative actions. On the other hand, it allows the shareholders to accompany and to participate in the establishment of guidelines for the administration of the enterprise, always under the presupposition that the manager acts on behalf of the interests of the company owner. Under the republican regime, established by the 1988 Federal Constitution, the citizens are the holders of the republic; thus, it is the responsibility of the public administrator to manage the public thing on behalf of the interests of society. The administration of the public resources, which is regulated by the Financial Law, must strictly follow the republican logic, but in this sense it is possible to identify potentials agency conflicts between public administrators and citizens. With the objective of ensuring the best application of the scarce financial resources collected from society, the Federal Constitution institutionalized a complex system of preservation of the public interest in the state financial administration, and this system is described in this work and is here denominated of Republican governance. This complex (which is constituted of norms and constitutional principles, infra-constitutional norms, planning and control mechanisms, besides forms of social participation) forms an institutional protection system for the good application of the State financial resources and it should also be useful to those who apply the law as a vector for the interpretation of Financial Law norms.
\end{abstract}

Key Words: Financial Law, corporate governance, public sector governance, public finances, transparency, accountability, principles of administration, public resources administration. 


\section{SINTESI}

Il mondo corporativo ha sviluppato um meccanismo per attenuare i conflitti di agenzia, derivanti dalle divergenze tra gli interessi degli azionisti e dei gestori professionali. L'adozione di pratiche di governanza corporativa nelle società impresariali, nelle quali il capitale è polverizzato tra migliaia di azionisti che non partecipano alla gestione dell'impresa, impone ai gestori un comportamento etico, in base alla buona fede, alla trasparenza, alla presentazione dei conti, per l'efficienza e per la responsabilità degli atti di gestione. D'altro lato, permette che gli azionisti seguono e partecipano alla fissazione delle direttrici dell'amministrazione dell'impresa, sempre con il presupposto che il gestore agisca in nome degli stessi proprietari. Nel regime repubblicano stabilito dalla Costituzione Federale del 1988, i cittadini sono i titolari della repubblica, toccando al gestore pubblico l'amministrazione della cosa pubblica, in favore degli interessi della società. La gestione delle risorse pubbliche, regolata dal Diritto Finanziario, deve seguire rigorosamente la logica repubblicana, ma in questo punto è possibile indetificare potenziali conflitti di agenzia tra $\mathrm{i}$ gestori pubblici e $\mathrm{i}$ cittadini. Con 1'obiettivo di garantire la migliore applicazione delle scarse risorse finanziare riscosse dalla società, la Costituzione Federale ha istituzionalizzato un complesso sistema di tutela dell'interesse pubblico nella gestione finanziaria statale, il sistema descritto in questo lavoro, qui denominato come governanza repubblicana. Questo complesso, costituito da norme e principi costituzionali, norme infracostituzionali, meccanismi di controllo e di progetto, oltre che a forme di partecipazione sociale, formano un sistema istituzionale di protezione alla buona applicazione delle risorse finanziare dello Stato e devono servire agli esecutori del diritto come vettore per l’interpretazione del Diritto Finanziario.

Parole-Chiavi: Diritto Finanziario, governanza corporativa, governanza nel settore pubblico, finanze pubbliche, trasparenza, contabilità, principi amministrativi, gestione delle risorse pubbliche. 


\section{ABREVIATURAS E SIGLAS}

ANAO - Australian National Office

CIPFA - British Chratered Institute of Public Finance and Accountancy

CVM - Comissão de Valores Mobiliários

GAO - General Accounting Office

IBGC - Instituto Brasileiro de Governança Corporativa

IFAC - International Federation of Accountants

INTOSAI - International Organization of Supreme Audit Institutions

NGP - Nova Gestão Pública

NPM - New Public Management

NSWAO - New South Wales Audit Office

OECD - Organization for Economic Co-operation and Development

QAO - Queensland Audit Office 


\section{SUMÁRIO}

1. INTRODUÇÃO

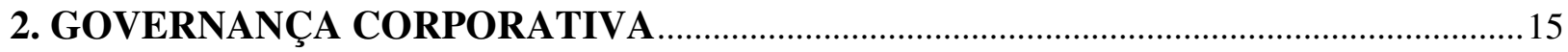

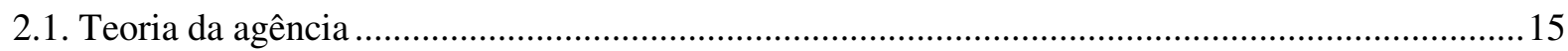

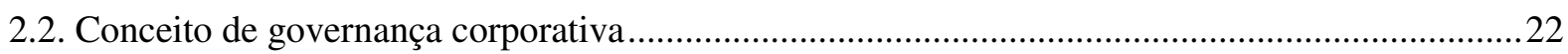

2.3. Aplicação da governança corporativa nas empresas ....................................................................29

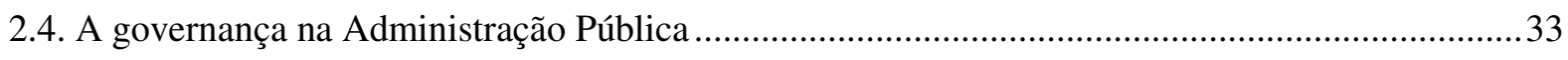

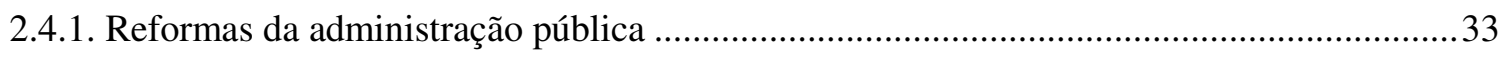

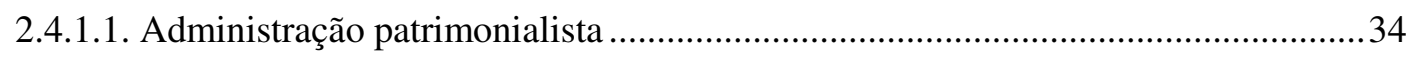

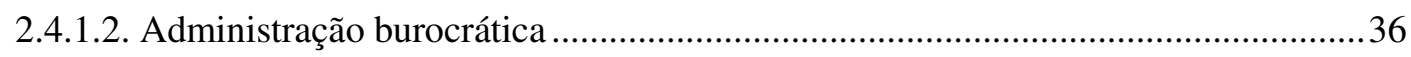

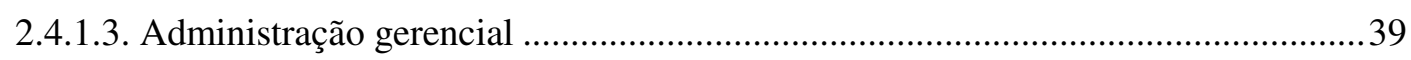

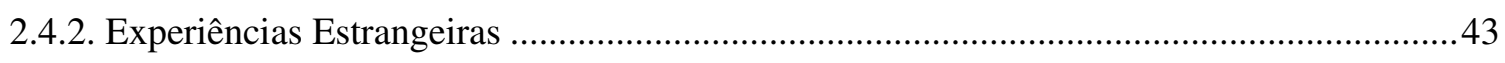

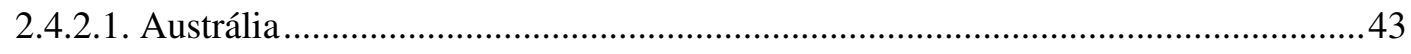

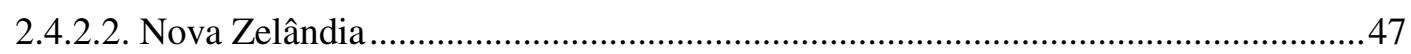

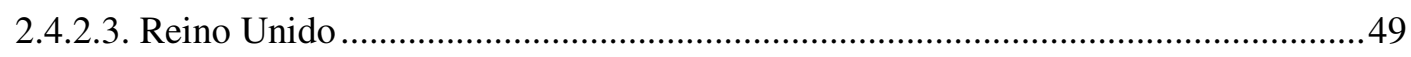

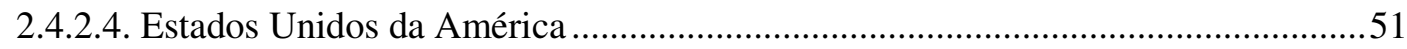

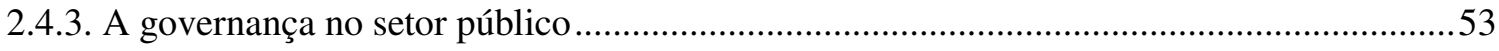

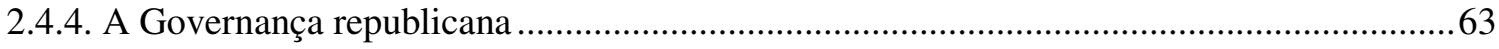

3. PRINCÍPIOS CONSTITUCIONAIS E GOVERNANÇA REPUBLICANA ................... 74

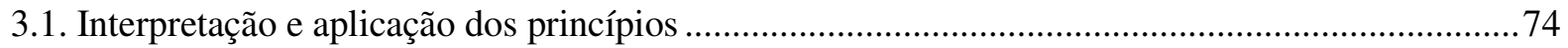

3.2. Princípio da legalidade e governança republicana ........................................................................... 80

3.3. Princípio da moralidade e a governança republicana........................................................................90

3.4. Princípio da eficiência e a governança republicana .........................................................................99

3.5. Princípio da economicidade e governança republicana ..................................................................112

3.6. Princípio da publicidade e da transparência na governança republicana .......................................119

4. GESTÃO FINANCEIRA ESTATAL E GOVERNANÇA REPUBLICANA ...................135

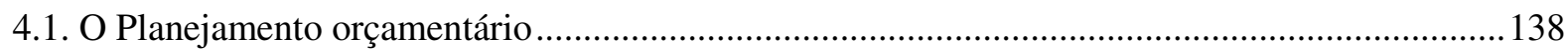

4.2. Eficiência do gasto público e avaliação de resultados ..................................................................149

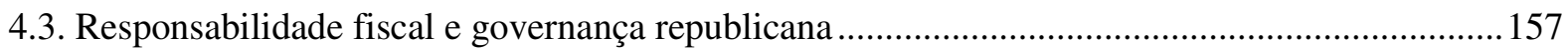


5. CONTROLE DA ADMINISTRAÇÃO E GOVERNANÇA REPUBLICANA 166

5.1. O controle interno 172

5.2. O controle externo 177

5.2.1. O controle externo realizado pelos Tribunais de Contas 183

5.2.1.1. A efetividade das decisões dos Tribunais de Contas 201

5.2.1.2. A governança republicana e os Tribunais de Contas .212

CONCLUSÕES 


\section{INTRODUÇÃO}

A finalidade imediata ou mediata de toda atividade estatal é o bem comum e o desenvolvimento do bem-estar dos cidadãos. A atividade financeira do Estado, por sua vez, torna possível a realização destes objetivos por meio da obtenção e alocação dos recursos econômicos, a serem aplicados de acordo com as prioridades estabelecidas pelos governantes.

O regime democrático de direito, estabelecido pela Constituição Federal de 1988, pressupõe que o Estado deve atuar efetivamente no desenvolvimento econômico e social, reduzindo desigualdades, promovendo o bem-estar coletivo e dos cidadãos individualmente, tendo como diretriz a participação direta da sociedade civil nestes processos. Essa moldura institucional estabelecida pela Carta Magna aumentou sobremaneira a importância do papel do Estado na sociedade e na economia, demandando uma administração pública ágil e extremamente complexa para fazer frente a estes desafios. Acrescente-se a isto as transformações tecnológicas e conjunturais das últimas décadas e fica fácil constatar-se que é preciso prosseguir com as reformas do setor público para adequá-lo às exigências atuais.

$\mathrm{Na}$ atividade financeira do Estado, os desafios são da mesma monta. A crise fiscal decorrente do endividamento público, a globalização e a volatilidade dos sistemas financeiros acrescentam obstáculos às insuperáveis dificuldades com a obtenção dos recursos necessários à implementação de políticas públicas e com a (in)eficiência do gasto público.

Na verdade, a crise do Estado é um fenômeno mundial, cujas causas são numerosas, passando pela ampliação acentuada das funções estatais - o que coincide com a passagem de um Estado liberal para um estado garantidor do bem-estar social (Welfare State) e do desenvolvimento econômico, até o processo intenso de globalização da economia vivido nos últimos anos, que certamente modificou o seu papel. A persistente crise do setor público contribui para reflexões sobre o papel do Estado e a forma como deve realizar suas funções. Mais do que isto, é preciso que o Poder Público estabeleça uma relação de absoluta transparência entre a administração pública e os cidadãos por ela jurisdicionados. 
Ao mesmo tempo em que se buscam novos paradigmas para a gestão pública, a corrida pela eficiência e qualidade deve ser acompanhada de novos padrões de governança no setor público, de modo a oferecer ao cidadão informações que possibilitem sua efetiva participação e a avaliação de desempenho do administrador público.

$\mathrm{Na}$ gestão financeira do Estado está presente, de forma acentuada, a noção da coisa pública ou da res publica. O Estado, para a realização de seus objetivos, retira compulsoriamente da sociedade uma parcela de sua riqueza. Esses recursos, originados do esforço de toda a coletividade, devem ser geridos de modo a produzir o melhor resultado possível para o interesse público. Mais do que isto, os cidadãos são os titulares desse patrimônio, razão pela qual devem participar ativamente da sua gestão.

A boa gestão dos recursos públicos e a efetiva participação da sociedade nesse processo são direitos dos cidadãos e devem ser garantidos por uma estrutura de governança, estabelecida pela própria Constituição Federal.

O conceito de governança é antigo, mas seu estudo e sistematização tiveram inicialmente como objeto o setor privado, mais especificamente as empresas de capital aberto.

$\mathrm{Na}$ evolução das empresas privadas, as corporações deixaram de ser administradas diretamente por seus proprietários e passaram para as mãos de gestores profissionais. Além disso, essa evolução transformou a própria estrutura de propriedade dos grandes conglomerados, que por meio do regime das sociedades anônimas e do mercado de capitais, passaram a ter centenas e até milhares de titulares espalhados pelo mundo.

A consequência dessa pulverização da propriedade é a separação entre gestor e proprietário. $\mathrm{O}$ acionista agora não tem mais a gestão do negócio, como tinha o proprietário da empresa, pois quem a administra são gestores profissionais, escolhidos por um conselho de administração.

Essa relação entre os gestores da empresa e seus acionistas foi, e ainda é, objeto de muita reflexão, pois entre os dois podem surgir conflitos decorrentes de eventual divergência de interesses. É o que a teoria econômica chama de conflitos de agência, onde o interesse do acionista, denominado pela teoria da agência de principal, não coincide com o do gestor, chamado de agente. 
Esses conflitos, no mundo empresarial, são atenuados com a adoção de uma série de mecanismos que direcionam e limitam a atuação do gestor e protegem os interesses dos acionistas. Esse complexo de mecanismos de proteção ao acionista minoritário é chamado de governança corporativa.

É possível vislumbrar conflitos de agência entre os cidadãos e os gestores públicos também. Essa analogia, em um regime republicano como o brasileiro, é perfeitamente possível, uma vez que os gestores públicos representam ou agem em nome do interesse público. Assim, para atenuar os efeitos dessas possíveis divergências é possível defender a adoção de mecanismos de governança pública, especialmente na gestão financeira do Estado.

$\mathrm{Na}$ verdade, esses mecanismos de governança já existem e estão previstos na própria Constituição Federal e na legislação ordinária. Trata-se de um complexo de princípios e dispositivos normativos que devem reger a gestão dos recursos públicos e, portanto, servir de vetor para a interpretação das normas de Direito Financeiro.

Neste trabalho, a partir da explanação teórica da possibilidade de aplicação de conceitos de governança ao setor público, serão apresentados os seus principais instrumentos no que tange à administração financeira e orçamentária do Estado, a fim de demonstrar que o regime democrático de direito, instituído a partir da Constituição de 1988, criou um sistema complexo de governança, onde a sociedade deve ter seus interesses protegidos, em especial aqueles que dizem respeito aos recursos compulsoriamente recolhidos para o financiamento da atividade estatal. Nessa linha, a aplicação do Direito Financeiro deve ser pautada por esse sistema.

O primeiro capítulo será dedicado à apresentação da teoria da agência e seus conflitos, dos conceitos de governança corporativa, da aplicabilidade desses conceitos à Administração Pública e, por fim, à definição de governança aplicada à gestão dos recursos públicos, denominada neste trabalho de governança republicana.

Após esses conceitos introdutórios, é a partir do capítulo 2 que o sistema de governança republicana, voltado às finanças públicas, será apresentado, iniciando-se com alguns dos princípios que regem a Administração Pública. Tais princípios são informadores desse sistema e devem pautar o aplicador do Direito Financeiro na tarefa de interpretação normativa. 
O capítulo 3 trata de aspectos práticos relevantes da gestão fiscal, onde são analisados o planejamento orçamentário, a eficiência no gasto público e, por fim, a responsabilidade fiscal, todos eles sob a ótica do sistema de governança republicana.

O capítulo 4 está dedicado a um dos pilares da governança republicana, qual seja a atividade de controle dos atos da Administração, tanto interno como externo. Com relação ao controle externo, alguma ênfase foi dada aos Tribunais de Contas, em razão de sua importância como guardião da res publica.

Às conclusões foram compiladas algumas proposições lançadas ao longo do trabalho, tudo no sentido de aprimorar o sistema de governança engendrado pela Constituição Federal. 


\section{GOVERNANÇA CORPORATIVA}

\subsection{Teoria da agência}

Da mesma forma que a gestão da res publica, nas democracias modernas, suscita grandes conflitos e debates, a administração de grandes empreendimentos privados e as questões envolvendo as relações entre seus investidores e os seus gestores é tema secular também. Adam Smith, autor de A Riqueza das Nações, já alertava, referindo-se aos gestores profissionais que não possuíam a propriedade do empreendimento que, "sendo administradores do dinheiro dos outros e não do seu próprio, não se pode esperar que fiquem de olho com a mesma vigilância ansiosa com que os sócios de uma parceria privada frequentemente vigiam o próprio dinheiro""1.

$\mathrm{Na}$ esfera privada, a separação entre propriedade e gestão ganha importância à medida que o desenvolvimento das empresas e dos negócios torna-os mais complexos (Slomski et al., 2008, p. 32) e especialmente a partir do desenvolvimento das sociedades por ações, em que a propriedade da empresa é pulverizada entre centenas ou milhares de acionistas. Atualmente, boa parte dos grandes conglomerados empresariais que atuam globalmente são sociedades anônimas, cujos acionistas estão espalhados ao redor do mundo e a administração do empreendimento é exercida por executivos profissionais, remunerados para representar os proprietários na gestão da companhia.

A Teoria da Agência trata basicamente das relações econômicas e administrativas entre o titular de um bem ou direito e os gestores profissionais contratados para administrar tais bens ou direitos. A abordagem que normalmente se faz à teoria da agência é econômica e o foco principal são as relações entre os acionistas de uma companhia e os executivos que administram o empreendimento. Antes de fazer a transposição de conceitos da teoria da agência à gestão pública, é inicialmente necessário compreender os problemas decorrentes desta relação, razão pela qual o enfoque inicialmente será eminentemente econômico, para então abordá-lo pela perspectiva das relações do Estado com os seus cidadãos.

\footnotetext{
${ }^{1}$ SMITH, Adam. An inquiry into the nature and causes of the wealth of Nations. London: Ward, Lock and Tyler, 1776. apud MORCK, Randal. Corporations. Discussion paper - Harvard Institute of Economy Research. Cambridge: HIER, n. 2101, p. 4, Jan. 2006. Disponível em: <http://www.economics.harvard.edu/journals/hier2006>. Acesso em: 14 set. 2009. Tradução nossa.
} 
A Teoria da Agência ou, no original, "Agency Theory" trata das implicações decorrentes de um contrato, sob o aspecto econômico e administrativo, onde o proprietário ou titular de um bem ou de um direito, denominado principal, contrata um terceiro, chamado de agente, para a realização de determinada tarefa, delegando-lhe poderes para tomada de decisões.

A essência da relação de agência é a separação entre propriedade e administração (Schleifer; Vishny, 1997, p. 740). Assim, relação de agência é definida por Michael Jensen e William Meckling (1976, p. 308) como:

[...] um contrato sob o qual uma ou mais pessoas (principal) contrata(m) outra pessoa (agente) para executar algum serviço em nome daquele(s), envolvendo a delegação de algum poder de tomada de decisão ao agente ${ }^{2}$. (tradução nossa)

Ainda limitando-se a análise à perspectiva empresarial, "as relações contratuais são a essência da firma, não só com empregados, mas com fornecedores, clientes, credores, entre outros" (Jensen; Meckling 1976, p. 310). Para Stephen Ross, Randolph Westerfield e Bradford Jordan (1998, p. 34), “A relação de agência existe sempre que o principal contrata o agente para cuidar de seus interesses". Nessa linha, juridicamente pode-se dizer que as relações de agência ocorrem basicamente em contratos em que uma parte delega à outra poderes para que esta aja em nome daquela na gestão de algum interesse ou direito, inclusive podendo tomar decisões, sempre sob a moldura de limites e condições estabelecidos para esta atuação. Com este escopo, podem ser citados como exemplos o mandato, o contrato de representação e o próprio contrato de trabalho.

Dessa relação entre o proprietário (principal) e gestor (agente), podem eventualmente emergir conflitos, desencadeados em razão de possíveis divergências de interesses entre principal e agente (Rozo, 2003, p. 23). Michael Jensen e William Mecklin (1976, p. 308), analisando comportamentos econômicos nas relações de agência, explicam que, "Se ambas as partes desta relação são maximizadoras de utilidade, existe uma boa

\footnotetext{
${ }^{2 " W e}$ define an agency relationship as a contract under which one or more persons (the principal(s)) engage another person (the agent) to perform some service on their behalf which involves delegating some decision making authority to the agent".
} 
razão para acreditar que o agente nem sempre agirá de acordo com os melhores interesses do principal”’3 (tradução nossa).

Eventuais conflitos de interesses entre principal e agente, observados na execução do contrato, são denominados de conflitos de agência.

Eugene Brigham e Joel Houston (1999, p. 17) definem um problema de agência como o "Conflito potencial de interesses entre o agente (o administrador) e (1) os acionistas externos à administração ou (2) os credores (portadores de títulos de dívida)".

Tratando especificamente da gestão de empresas, Michael Hitt, Duane Ireland e Robert Hoskisson (2003, p. 312) explicam que, quando há separação entre propriedade e controle, podem surgir problemas da relação principal-agente ou, mais especificamente, da relação entre os proprietários (acionistas) e os gestores da empresa, tendo em vista os interesses divergentes desses atores em relação aos dos proprietários. $\mathrm{O}$ agente pode, pois, em detrimento dos interesses dos proprietários ou da empresa, tomar decisões que maximizem os seus interesses individuais. Por isso, a relação principalagente pode levar ao oportunismo administrativo ${ }^{4}$ (Akdere; Azevedo, 2006, p. 50), entendido como atitudes ou comportamentos tortuosos em relação à companhia na busca de interesses pessoais (Hitt, Ireland e Hoskisson, 2003, p. 312). Os desvios, por outro lado, podem ser decorrentes simplesmente de deficiências no estabelecimento de diretrizes ou no monitoramento das ações. De todo modo, os conflitos de agência normalmente estão acompanhados da dificuldade de o principal monitorar adequadamente o comportamento do agente $^{5}$.

Stephen Ross et al. (1998, p.34) apresentam um exemplo singelo que demonstra com clareza o potencial conflito de interesses entre principal e agente, quando o primeiro delega ao segundo poderes para a venda de um bem, remunerando-o com uma comissão fixa. O agente, na terminologia utilizada na teoria da agência, terá como incentivo vender o bem para receber a comissão, mas não o fará, necessariamente, pelo melhor preço de mercado, uma vez que bastará a venda para que sua recompensa seja paga. Note-se que, neste exemplo, caso o principal, proprietário do bem, não esteja

\footnotetext{
3“If both parties to the relationship are utility maximizers, there is good reason to believe that the agent will not always act in the best interests of the principal".

4"Managerial opportunism" na acepção dos autores.

${ }^{5}$ Cf. EISENHARDT, Katheleen M. Agency theory: an assessment and review. Academy of Management Review, v. 14, n. 1, p. 61, 1989.
} 
adequadamente informado sobre o mercado do bem a ser vendido ou acerca das providências tomadas pelo seu representante, maior será a chance de que haja divergência concreta entre seus objetivos e os resultados produzidos pelo agente.

É possível concluir que as relações de agência podem envolver um conflito potencial de interesses e uma defasagem entre as informações de que o agente dispõe e as que o principal possui. Esta defasagem, também chamada de assimetria informacional, dificulta o monitoramento das ações pelo principal, uma vez que o agente possui normalmente melhores informações que aquele (Pindyck; Rubinfeld ${ }^{6}$ apud Slomski, 2003, p. 432).

Há várias razões a explicar por que nem sempre a comunicação entre principal e agente é suficientemente clara ou efetiva, tanto para o principal quanto para o agente. Apenas como exemplo, a informação enviada pelo principal ao agente pode ser imprecisa ou insuficiente, deixando obscuros os efetivos objetivos dos proprietários, ou a informação também pode ter sido deliberadamente ocultada pelo agente, como decorrência da divergência de interesses.

Assim, ocorre a chamada assimetria informacional quando a capacidade do principal em monitorar o trabalho do agente fica limitada, comprometida ou interrompida por razões que são do conhecimento apenas do agente, em razão de sua proximidade com a gestão dos negócios (Akdere; Azevedo, 2006, p. 46). De outra banda, também há assimetria informacional quando o principal não logra transmitir ao agente, com clareza e precisão, as diretrizes e os objetivos do negócio.

Em síntese, a teoria econômica apresenta essa relação entre principal e agente, denominada, também, de problema de agência, como um elemento essencialmente contratual $^{7}$, possibilitando a existência de conflito de interesses e/ou de assimetria

\footnotetext{
${ }^{6}$ PINDYCK, R. S.; RUBINFELD, D. L. Microeconomia. Tradução de Pedro Catunda e revisão técnica de Roberto Luis Troster. São Paulo: Makron Books, 1994.

${ }^{7}$ Cf. JENSEN, Michael; MECKLING, William. Theory of the firm: managerial behavior, agency costs and ownership structure. Journal of Financial Economics, [S.1.], v. 3, n. 4, p. 305-360, Oct. 1976, sobre a teoria dos contratos. Os referidos autores definiram a empresa como um complexo de contratos. As relações entre principal e agente são balizadas por contrato, pois supõe-se que os gestores e os acionistas, ao serem deixados por sua conta, procurarão agir segundo seus próprios interesses. Os conflitos e problemas decorrentes desta relação contratual são originados de imperfeições e omissões nos contratos ou de problemas no monitoramento de sua execução, além de deficiências na comunicação e informação. Jensen e Meckling (1976) apontam que a elaboração e execução deste contrato, entre principal e agente, possui custos, denominados como custos de agência. Entre esses custos estão: (1) a própria elaboração do contrato; (2) os custos de monitoramento da execução por parte do principal e (3) os prejuízos ou perdas decorrentes de decisões equivocadas do agente, que falha no seu papel de maximizar o resultado em favor do principal.
} 
informacional, resultante da separação entre a propriedade e o controle (gestão). É na essência desses conflitos que se originam as dificuldades que os investidores encontram em garantir que seus investimentos tenham o retorno desejado ou que decisões do agente acarretem perdas ao principal ${ }^{8}$.

A síntese de José Danúbio Rozo (2003, p. 23) ordena de maneira didática todos os elementos da teoria da agência:

A teoria da agência trata de problemas resultantes dos conflitos de interesse que emergem numa relação de contrato, formal ou informal, quando as partes contratantes possuem informação assimétrica ou há presença de interesse. O principal objetivo dessa teoria é explicar como as partes contratantes efetuam seus contratos de forma a minimizar os custos associados aos problemas de informação assimétrica e incerteza.

Sendo o conflito de agência resultante de imperfeições ou omissões contratuais, soluções para atenuar tais problemas estariam na elaboração de contratos que pudessem pré-estabelecer, de forma clara e mais abrangente possível, as formas de relacionamento, deveres e obrigações das partes, além das possibilidades de contingenciamento, uma vez que é impraticável a inclusão de todas as possibilidades em um instrumento contratual (Yamamoto 2005, p. 26). De fato, qualquer instrumento de ajuste entre principal e agente, por mais completo que se pareça, estará sujeito a incertezas e variantes não previstas, razão pela qual os instrumentos de monitoramento e avaliação da gestão tornam-se indispensáveis para minimizar os problemas de agência ${ }^{9}$.

À luz da teoria da agência e dos conflitos existentes entre principal e agente, é possível traçar um paralelo, ainda utilizando conceitos econômicos, entre as empresas privadas e o Estado.

Nos regimes democráticos de direito, a relação entre o Estado e seus administrados também pode ser caracterizada como uma relação entre agente e principal,

\footnotetext{
${ }^{8}$ Cf. COASE, Ronald. The nature of the firm. Economica, [S.1.], v. 4, p. 386-405, 1937, sobre a teoria da firma e Jensen e Meckling (JENSEN, Michael; MECKLING, William. op. cit., p. 305-360), além de Fama e Jensen (FAMA, Eugene; JENSEN, Michael. Separation of ownership and control. Journal of Law and Economics, [S.1.], v. 26, p. 301-327, June, 1983), precursores da teoria da agência.

${ }^{9}$ Cf. SLOMSKI, Valmor; MELLO, Gilmar Ribeiro de; TAVARES FILHO, Francisco; MACÊDO, Fabrício de Queiroz. Governança corporativa e governança na gestão pública. São Paulo: Atlas, 2008. p. 38. Os autores entendem que, dada a impossibilidade prática de um contrato perfeito, que impeça os conflitos de agência, estes deverão ser minimizados pela atuação na gestão, o que importará necessariamente em perdas para o principal, seja pelos custos das ações de monitoramento e acompanhamento, seja por comportamentos inadequados do agente.
} 
estando de um lado, os políticos e gestores públicos, no papel de agentes, e de outro, os cidadãos, como principais.

Adam Przeworski (2006, p.40) aponta que os conflitos existentes entre cidadão e Estado geralmente decorrem da divergência de interesses entre os administrados, os políticos e os burocratas, assim definidos aqueles que profissionalmente atuam na administração pública. Przeworski (2006, p. 46) identifica três categorias de relações agente/principal: (1) entre o Estado e os agentes econômicos; (2) entre os políticos e os burocratas e (3) entre os políticos e os cidadãos.

De fato, é possível identificar relações de agência entre os governantes e os cidadãos, sendo estes os principais, e aqueles, os agentes. Slomski (2005, p. 30) entende que as entidades públicas devem ser vistas sob a perspectiva da teoria da agência, existindo relações de agência entre gestores e cidadãos. Gambhir Bhatta (2003, p. 7) também defende a existência de relações de agência entre ministros e servidores públicos $^{11}$.

Sendo o cidadão o titular da res publica, é preciso que estejam à sua disposição instrumentos que lhe permitam monitorar as ações dos governantes e minimizar os problemas de agência. Quando se trata dos recursos públicos, aplicados pelos gestores, é preciso implementar um modelo que proporcione ao cidadão transparência e clareza de como estão sendo geridos tais recursos.

Os instrumentos de governança corporativa, quando implementados pelas organizações, permitem aos proprietários e, no caso da Administração Pública, aos cidadãos, o controle e acompanhamento da gestão, minimizando os conflitos de agência.

Alexandre Di Miceli Silveira (2002, p. 14) entende que a Governança Corporativa é um "conjunto de mecanismos de incentivo e controle que visa harmonizar a relação entre acionistas e gestores pela redução dos custos de agência, numa situação de separação de propriedade e controle”. Hitt, Ireland e Hoskisson (2002, p. 311), além de

\footnotetext{
${ }^{10}$ Slomski (SLOMSKI, Valmor. Controladoria e governança na gestão pública. São Paulo: Atlas, 2005. p. 30) aponta que as relações entre Estado e cidadãos são típicas relações de agência, pois três requisitos apontados por Siffert Filho (1996) encontram-se presentes, quais sejam: “(1) o agente (gestor público) dispõe de vários comportamentos possíveis a serem adotados; (2) a ação do agente (gestor público) afeta o bem-estar das duas partes e (3) as ações do agente (gestor público) dificilmente são observáveis pelo principal (cidadão), havendo dessa forma, assimetria informacional”.

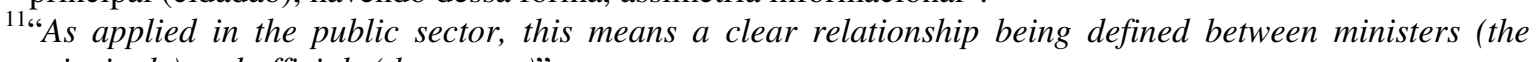
principals) and officials (the agents)".
} 
Antônio Gledson Carvalho (2002, p. 19), entendem que os mecanismos de governança e controle também visam à redução dos problemas de agência, prevenindo para que tais conflitos não venham a causar problemas ou detectando rapidamente os desvios para sua correção.

Para Álvaro Clark de La Cerda (2000, p. 2), pode-se dizer que um sistema de governança corporativa possui dois objetivos essenciais:

[...] prover uma estrutura eficiente de incentivos para a administração, visando à maximização de valor da empresa e estabelecer responsabilidades e outros tipos de salvaguardas para evitar que os acionistas majoritários, membros da diretoria e gestores (insiders) promovam qualquer tipo de expropriação de valor em detrimento dos acionistas minoritários e credores (outsiders).

A governança corporativa, por meio de seus mecanismos de gestão da empresa, visa a minimizar os problemas de agência (Marques, 2007, p. 13). Emerson Pedreira e José Odálio dos Santos (2002, p. 2) descrevem como uma estrutura de governança em uma empresa pode atenuar os potenciais conflitos de agência:

[...] a estrutura de governança deve especificar a atribuição dos direitos e responsabilidades entre os diferentes participantes da empresa - como os dirigentes, acionistas, conselho de administração e outros stakeholders e detalhar as regras e procedimentos para tomada de decisões no que se refere a assuntos corporativos. Por fazer isso, provê a estrutura pela qual os objetivos da companhia são definidos e os meios para atingir seus objetivos e monitorar seu desempenho.

A utilização de instrumentos de governança corporativa no setor público, especialmente quando se trata da gestão de recursos públicos, é mandamental, como se verá, sendo o Direito Financeiro a moldura normativa para a sua concretização. A sociedade, por meio do recolhimento de tributos, financia a ação da Administração Pública e é por essa razão que o arcabouço normativo, que envolve a administração financeira do Estado, prevê o funcionamento de um sofisticado mecanismo de governança corporativa, cujo objetivo maior é a proteção dos interesses dos cidadãos. 


\subsection{Conceito de governança corporativa}

A utilização do termo "governança corporativa" está inicialmente vinculada à atividade empresarial, mais especificamente ao mercado de capitais e às sociedades por ações, cujo desenvolvimento foi acentuado a partir da primeira metade do século XX.

A governança corporativa reflete-se na forma como a companhia é gerida e como se estruturam e se desenvolvem as relações entre os acionistas, os dirigentes da empresa e os demais interessados no seu desempenho (stakeholders ${ }^{12}$ ).

Governança Corporativa é conceito introduzido pelas ciências econômicas e, nas palavras de Alexandre Di Miceli da Silveira (2006, p. 27), pode ser caracterizado como "[...] o conjunto de mecanismos que visam a aumentar a probabilidade de os fornecedores de recursos garantirem para si o retorno sobre seu investimento [...]”.

Para o Instituto Brasileiro de Governança Corporativa (IBGC) (2009):

Governança Corporativa é o sistema pelo qual as organizações são dirigidas, monitoradas e incentivadas, envolvendo os relacionamentos entre proprietários, conselho de administração, diretoria e órgãos de controle. As boas práticas de governança corporativa convertem princípios em recomendações objetivas, alinhando interesses com a finalidade de preservar e otimizar o valor da organização, facilitando seu acesso ao capital e contribuindo para a sua longevidade.

Adriana Andrade e José Paschoal Rossetti (2007, p. 141) entendem que:

[...] a governança corporativa é um conjunto de princípios, propósitos, processos e práticas que regem o sistema de poder e os mecanismos de gestão das empresas, abrangendo: propósitos dos proprietários; sistema de relações proprietários-conselhos-direção; maximização do retorno total dos proprietários, minimizando oportunismos conflitantes com este fim; sistema de controle e de fiscalização das ações dos gestores; sistema de informações relevantes e de prestação de contas às partes interessadas nos resultados corporativos; sistema guardião dos ativos tangíveis e intangíveis das companhias.

\footnotetext{
${ }^{12}$ A conceituação de Stakeholders dada por SLOMSKI, Valmor; MELLO, Gilmar Ribeiro de; TAVARES FILHO, Francisco; MACÊDO, Fabrício de Queiroz. op. cit., p. 5 é: "denominação dada ao conjunto de todas as partes envolvidas em uma empresa. São elas, além dos acionistas, empregados, clientes, fornecedores, credores, governos, entre outros".
} 
Lílian Regina dos Santos (2004, p. 20) sintetiza a definição de Governança Corporativa como:

[...] a capacidade de controlar o comportamento dos agentes de uma organização, de modo a fazer que os seus recursos sejam mobilizados e aplicados de forma eficaz e eficiente e sob níveis de risco adequados para o cumprimento da missão e dos objetivos requeridos pelos acionistas e outros participantes relevantes.

Tratando-se a governança corporativa de um complexo de estruturas e instrumentos que definem as relações entre os acionistas de uma companhia, seus dirigentes e demais interessados, em virtude da extensão e diversidade de seus impactos, sua conceituação varia dependendo da perspectiva e do contexto em que se analisa o fenômeno. É possível focar na dimensão financeira da relação entre o investidor e o gestor. Nesse caso, as estruturas de governança devem garantir o retorno do investimento aos acionistas. Essa é a visão estritamente financeira, apresentada por Andrei Shleifer e Robert Vishny (1997, p. 737), para quem "corporate governance deals with the ways in which suppliers of finance to corporation assure themselves of getting a return their investment" $^{\prime \prime}$. Os autores ainda acrescentam como objeto da governança corporativa a forma como os fornecedores de capital da companhia podem exercer o controle sobre os administradores, assegurando-se de que não empregarão os recursos da empresa em maus projetos. $^{14}$

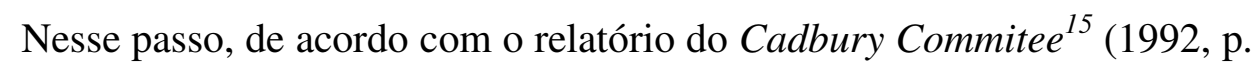
20), "A governança é o sistema e a estrutura de poder que regem os mecanismos através dos quais as companhias são dirigidas e controladas."

\footnotetext{
13“'Governança corporativa ocupa-se dos instrumentos pelos quais os fornecedores de recursos garantem que obterão para si o retorno sobre seus investimentos" (tradução nossa).

14"How do the suppliers make sure that managers do not steal the capital they supply or invest it in bad projects? How do the suppliers of finance control managers."

${ }^{15} \mathrm{O}$ Cadbury Committee foi criado na Grã-Bretanha para a formulação de recomendações para o mercado de capitais britânico, que à época fora atingido com uma série de escândalos empresariais e a quebra de algumas das suas maiores empresas. $\mathrm{O}$ referido comitê, formado por membros oriundos do mercado de capitais, do governo e do Instituto dos Contadores Certificados (INSTITUTO BRASILEIRO DE GOVERNANÇA CORPORATIVA (IBGC). Uma década de governança corporativa: história do IBGC, marcos e lições da experiência. São Paulo: Saint Paul Instituto of Finance; Saraiva, 2006. p. 71), foi assim batizado em referência a Sir Adrian Cadbury, seu presidente. O resultado dos trabalhos deste comitê, denominado The Financial Aspects of Corporate Governance, foi um dos precursores dos diversos códigos de governança instituídos pelo mundo e teve como principais focos a transparência e a prestação de contas.
} 
Todavia, a governança corporativa também envolve outros aspectos, além das relações entre acionistas e gestores. A governança corporativa é definida pelas estruturas que regem a tomada estratégica de decisão e o monitoramento do desempenho em uma corporação (Hitt; Ireland; Hoskisson, 2002, p. 402). Desta forma, é justo ampliar o âmbito de sua investigação aos demais interessados no desempenho da empresa (stakeholders). Assim, não se pode analisar a governança apenas sob a perspectiva dos seus acionistas e gestores, uma vez que o desempenho das corporações afeta direta ou indiretamente outros interessados, que de alguma forma com elas se relacionam, tais como empregados, clientes, fornecedores, governos, comunidade local, credores, entre outros (Slomski et al., 2008, p. 5). Ao contrário do modelo estritamente financeiro de governança, outros modelos incluem em sua conceituação todos aqueles que de alguma forma influenciam ou são influenciados pelos processos institucionais da organização, estejam eles envolvidos ou não na organização da produção e venda de produtos ou serviços (Turnbull, 1997, p. 181).

Dando maior amplitude ao alcance da governança corporativa, a Comissão de Valores Mobiliários (CVM) assim a conceitua:

[...] o conjunto de práticas que tem por finalidade otimizar o desempenho de uma companhia ao proteger todas as partes interessadas, tais como investidores, empregados e credores, facilitando o acesso ao capital. A análise das práticas de governança corporativa aplicada ao mercado de capitais envolve, principalmente: transparência, equidade de tratamento dos acionistas e prestação de contas ${ }^{16}$.

Segundo a Organization for Economic Cooperation and Development

(OECD) (OECD, 2004, p. 11), a governança corporativa pode ser definida como:

[...] a set of relationships between a company's management, its board, its shareholders and other stakeholders. Corporate Governance also provides the structure through which the objectives of the company are set, and the means of attaining those objectives and monitoring performance are determined. Good corporate governance should provide proper incentives for the board and management to pursue objectives that are in the interests of the company and its shareholders and should facilitate effective monitoring ${ }^{17}$.

\footnotetext{
${ }^{16}$ Trecho retirado das COMISSÃO DE VALORES MOBILIÁRIOS (CVM). Cartilha de Recomendações da CVM sobre Governança Corporativa, 2002. Disponível em: <www.cvm.gov.br>.

17،[...] um conjunto de relacionamentos entre a gerência da companhia, seus conselhos, acionistas e outros stakeholders. Governança Corporativa também fornece a estrutura pela qual os objetivos da companhia são estabelecidos, além de determinar os meios para atingi-los e para o monitoramento da performance. A boa
} 
$\mathrm{Na}$ mesma linha, William Witherell (2000, p. 1), ao analisar a importância que o fortalecimento do mercado de capitais tem para o desenvolvimento econômico dos países, comenta que

Governance is more than just board processes and procedures. It involves the full set of relationships between a company's management, its board, its shareholders and its other stakeholders, such as its employees and the community in which it is located ${ }^{18}$.

Também Sérgio de Iudícibus et al. (2003, p. 118) conceituam a governança corporativa como um:

Sistema pelo qual as empresas são dirigidas e controladas, que assegura aos proprietários o governo estratégico da empresa e a efetiva monitoração da diretoria executiva. A relação entre propriedade e controle ocorre por meio do conselho de administração, da auditoria independente e do conselho fiscal, que devem assegurar aos proprietários a equidade (fairness), a transparência (disclosure), a responsabilidade pelos resultados (accountability) e o cumprimento de leis e normas (compliance).

Segundo Marina Mitiyo Yamamoto e José Estevam Prado (2003), o termo "corporate governance" já era utilizado em 1960 para designar as estruturas e funcionamento das sociedades anônimas no mercado de capitais norte-americano, "onde a relação propriedade e administração foi se tornando mais fraca pela pulverização do controle acionário".

O aprofundamento dos estudos acerca da governança corporativa iniciouse nas décadas de 1980 e 1990, diante da necessidade de fortalecimento dos mercados de capitais ao redor do mundo, vítimas de crises causadas por escândalos no mercado corporativo.

Alguns marcos importantes para a compreensão e desenvolvimento dos conceitos e práticas de governança corporativa merecem destaque.

governança deve fornecer incentivos específicos para os conselhos e para os gestores na busca dos objetivos que representam os interesses da companhia e dos acionistas, bem como deve facilitar o efetivo monitoramento dos negócios.” (tradução nossa).

18 “Governança não se restringe a processos e procedimentos dos órgãos de administração. Envolve a gama completa de relações entre os gestores da companhia, o conselho, os shareholders e outros stakeholders, tais como seus empregados e a comunidade na qual se encontra” (tradução nossa). 
O primeiro código de boas práticas em matéria de governança corporativa foi elaborado pelo denominado Comitê Cadbury, cujo relatório foi publicado em 1992 (IBGC, 2006, p. 71).

O Comitê Cadbury, instituído em maio de 1991, contava com representantes de vários setores ligados ao mercado de capitais britânico e das entidades de profissionais de contabilidade. O objetivo precípuo do Comitê foi estabelecer recomendações de governança que propiciassem maior transparência e credibilidade aos relatórios financeiros das companhias abertas do Reino Unido (Cadbury Committee, 1992).

As carências, tanto na confiabilidade dos relatórios contábeis e financeiros, como na capacidade dos sistemas de auditoria de estabelecer salvaguardas suficientes aos acionistas e demais interessados no mercado de capitais, foram detectadas após escândalos corporativos e péssimos resultados de algumas das maiores empresas inglesas no final da década de 1980 (IBGC, 2006, p. 71). O relatório apontou também para a ação insuficiente dos conselhos de administração no monitoramento das companhias, em especial para o descontrole sobre a remuneração de membros da diretoria e para a ausência de um sistema claro de responsabilização de dirigentes empresariais (Cadbury Committee, 1992).

A par da importância que o bom funcionamento do mercado de capitais e a eficiência das empresas têm na posição competitiva dos países, o Comitê Cadbury elaborou o seu relatório final, cujo código de melhores práticas, desenhado para atingir altos padrões de comportamento corporativo em um mercado acionário bastante pulverizado, é o seu ponto principal (Cadbury Committee, 1992).

Além das contribuições iniciais às boas práticas de governança corporativa, em particular em relação à prestação de contas e à transparência, o Relatório Cadbury foi o precursor de outros estudos e códigos relacionados ao tema no próprio Reino Unido e em outros países.

Na França, em 1995, há a publicação do Relatório Vienot, que também estabelece recomendações para aumentar o padrão de governança no mercado francês. Seguiram-se outras experiências em países como Alemanha (1997), Japão (1998) e Estados Unidos (2002), com a edição da Lei Sarbanes-Oxley. Em 2006, segundo o IBGC, os 
códigos de boa governança já estavam presentes em mais de 60 países (IBGC, 2006, p. 7274).

Nos Estados Unidos, a preocupação com a prestação de contas e a transparência da gestão remonta à década de 1920, quando as sociedades por ações se desenvolveram com grande intensidade e os desafios para sua regulação cresciam na mesma proporção.

Em meio a uma série de escândalos que abalaram o mercado de capitais norte-americano $^{19}$, foi editada nos Estados Unidos da América, em 30 de julho de 2002, a Lei Sarbanes-Oxley.

De fato, a onda de falências e escândalos financeiros ocorridos no final da década de 1990 e no início desta década demonstrou que os sistemas de controle e monitoramento das sociedades anônimas nos Estados Unidos da América era deficiente, gerando descrédito no mercado financeiro.

O escopo básico da lei, portanto, foi o de recuperar a credibilidade do mercado de capitais norte-americano (Santos; Leme, 2004), regulamentando as regras de governança das companhias abertas e estabelecendo rígidos padrões de comportamento no que tange à transparência (disclosure), prestação de contas (accountability), conformidade com marcos legais (compliance) e equidade (fairness) (IBGC, 2006, p. 75). Mais do que isto, a Lei define claramente o papel e as responsabilidades de gestores, conselheiros e auditores, incluindo sanções civis e penais para desvios de conduta.

A confiança nos mercados de capitais é ingrediente necessário ao desenvolvimento econômico das nações, daí a razão pela preocupação com a elevação do grau de governança corporativa das companhias abertas.

\section{A Organization for Economic Co-operation and Development (OECD)}

reafirma a importância da boa governança como fator de eficiência e do desenvolvimento econômico dos países (OECD, 2004, p. 11). Por essa razão, a OECD divulgou, em maio de 1999, a primeira versão dos "Principles of Corporate Governance", com recomendações gerais sobre governança corporativa, que foi atualizada em 2001 e 2004 (OECD, 2004), e

\footnotetext{
${ }^{19}$ Dentre os escândalos que geraram enormes prejuízos a acionista e fundos de investimentos e que precederam a edição da Lei Sarbanes-Oxley, destacam-se os casos da empresa Enron, que também envolveu a empresa de auditoria Arthur Andersen, além da quebra de outras companhias, tais como WorldCom, Global Crossing, Adelphia e Tyco, entre outras.
} 
em 2005 lançou as diretrizes para a governança corporativa de empresas sob controle ou influência estatal.

Nos seus princípios, a OECD reforça alguns valores que devem permear a boa governança corporativa. Inicialmente (OECD, 2004, p. 17), a gestão das sociedades deve sempre buscar a transparência e eficiência dos mercados, bem como deve haver discriminação clara entre as responsabilidades de cada um dos gestores ou grupos envolvidos com a gestão.

No segundo tópico de seus princípios (OECD, 2004, p.18), a Organização recomenda a proteção e facilitação ao exercício dos direitos dos acionistas.

No terceiro item (OECD, 2004, p.20), os princípios focam no tratamento equitativo de todos os acionistas, incluindo os minoritários e os estrangeiros, cabendo provê-los de instrumentos de reparação pela violação dos seus direitos.

O quarto tópico dos princípios (OECD, 2004, p. 21) trata dos demais sujeitos com interesse relevante no governo da sociedade (stakeholders), que também devem ter seus direitos preservados, tanto aqueles legalmente consagrados como aqueles decorrentes de relação contratual. Os trabalhadores e os credores da companhia estão incluídos no rol de interessados na gestão da empresa e devem ter à disposição mecanismos de reparação para eventuais violações dos seus direitos.

A transparência deve pautar as relações entre a gestão e os interessados, notadamente no que tange à situação financeira, ao desempenho, às participações sociais relevantes, à política de remuneração dos dirigentes, aos riscos previsíveis, entre outros (OECD, 2004, p.22).

No último tópico (OECD, 2004, p.24), os princípios da OECD recomendam que o governo das sociedades deve assegurar a gestão estratégica da empresa, um acompanhamento e fiscalização eficazes da gestão pelo órgão de administração e a responsabilização do órgão de administração perante a empresa e os seus acionistas, devendo os gestores atuar com diligência e boa-fé, sempre direcionados ao bom desempenho da companhia e aos interesses dos proprietários.

Independentemente de sua aplicação no âmbito privado ou na gestão pública, a governança corporativa pode então ser definida como um complexo de 
mecanismos institucionais, contratuais ou normativos, que permitem que a gestão de determinada organização seja direcionada, monitorada e avaliada pelos seus proprietários ou titulares, pautando-se sempre pela transparência, prestação de contas, eficiência, diligência e boa-fé.

\subsection{Aplicação da governança corporativa nas empresas}

A abrangência dos mecanismos de governança corporativa varia, como já visto, dependendo do enfoque mais ou menos amplo que se faça. Entendendo-se a governança apenas como mecanismo de proteção financeira do investimento realizado pelo acionista, os instrumentos de governança ficam limitados à performance econômica obtida pelo gestor. Porém, se for ampliado o escopo da abordagem, os mecanismos de governança destinam-se a todos aqueles que de alguma forma têm algum interesse no desempenho da empresa, incluindo, além dos acionistas, os empregados, os credores, o governo, a comunidade local, dentre outros.

Essa diferença de abordagem foi identificada por estudiosos do tema, que apontam a existência de diferentes modalidades de governança corporativa. Marina Mityio Yamamoto e José Estevam Prado (2003) apontam a existência de dois modelos de governança: o modelo anglo-americano e o modelo germânico-japonês.

O mercado de capitais, tanto nos Estados Unidos, como na Grã-Bretanha, tem como característica a pulverização das ações, além da grande mobilidade e liquidez, motivo pelo qual o enfoque principal recai sobre o desempenho financeiro da empresa. Já no modelo anglo-americano, por tratar-se de empresas com grande dispersão acionária, o poder individual dos acionistas é fraco e um desempenho insatisfatório da empresa normalmente é visto como motivação para a venda das ações, com consequências, como aquisições hostis ou fusões (Okimura, 2003, p. 26). A proteção dos interesses dos acionistas minoritários nesse modelo é garantida pela transparência e por disposições legais. Os mecanismos de governança estão previstos em um sistema legal (enforcement) que, segundo Fabrício de Queiroz Macedo (2006, p. 23), “intervém e regula de forma eficiente as relações entre credores, acionistas e gerentes das corporações, tendo como objetivo principal para as empresas a criação de valor para os acionistas". 
Já no modelo germânico-japonês há presença de grandes investidores como proprietários de parcela relevante do capital da empresa, atuando como seus controladores. Por essa razão, a administração da companhia normalmente está mais engajada com os interesses do controlador. Rodrigo Takashi Okimura (2003, p. 26) aponta que os grandes investidores podem ser bancos, outras instituições financeiras, empresas de participação, além de estruturas familiares. Ocorre também com frequência a aquisição de parcelas relevantes do capital por fundos de pensão e fundos de investimento. O modelo nipo-germânico de governança tem foco em um investidor de longo prazo, ao contrário do modelo anglo-saxão, cuja liquidez dos papéis é característica das mais relevantes para o aplicador (Tavares Filho, 2006, p.50).

Uma característica importante do modelo nipo-germânico de governança corporativa, apresentada por Fabrício Macêdo (2006, p. 24), é a preocupação com um grupo mais amplo de interesses pelas atividades da companhia, quais sejam, empregados, fornecedores, clientes, credores, comunidade e governo. ${ }^{20}$ Assim, para Fabrício Macêdo (2006, p. 24), "No modelo nipo-germânico, as empresas devem equilibrar os interesses dos acionistas com aqueles de outros grupos que são afetados pelas suas atividades, como, por exemplo, empregados, fornecedores, clientes e comunidade (stakeholders)", ao contrário do modelo anglo-saxão, cujo foco da governança é a defesa dos interesses dos acionistas.

Em ambos os casos, a existência de mecanismos de governança corporativa está diretamente vinculada com a estrutura legal que o Estado estabelece. Para Fabrício Macêdo (2006, p. 26),

\footnotetext{
A base fundamental é a de que a proteção legal (ou a sua falta) determinaria os diferentes modelos de governança corporativa existentes nos diferentes países e seria um fator determinante para o desenvolvimento do mercado de capitais e de seus agentes, e dessa forma influenciaria a estruturação dos mecanismos de financiamento das empresas. Os países de ambiente legal com origem no direito comum, como, por exemplo, os Estados Unidos e o Reino Unido, teriam uma melhor proteção legal para os investidores - e consequentemente mercado de capitais mais desenvolvidos - enquanto os países de ambiente legal com origem no Direito Civil francês, como, por exemplo, o Brasil, teriam pior proteção aos investidores.
}

\footnotetext{
${ }^{20}$ Também denominados de "stakeholders".
} 
Essa opinião é corroborada por Rafael La Porta et al. (2000) e Andrei Schleifer e Robert Vishny (1997, p. 770), que entendem que a ausência de leis apropriadas ou a fragilidade no sistema judiciário torna a proteção legal aos investidores menos eficaz. Esse é o caso específico do Brasil, onde, segundo Alexandre Di Miceli Silveira (2002, p. $31)$,

[...] a alta concentração da propriedade e do controle das companhias, aliada à baixa proteção legal dos acionistas, faz com que o principal conflito de agência no país se dê entre acionistas controladores e minoritários, e não entre acionistas e gestores, como nos países de origem anglo-saxônica com estrutura de propriedade pulverizada.

Independentemente do modelo ou da abrangência de seus instrumentos, o certo é que alguns fundamentos da boa governança corporativa são comuns a qualquer sistema e se adaptam perfeitamente para a transposição ao setor público.

Os Princípios básicos, presentes no Código das Melhores Práticas de Governança Corporativa do IBGC (2004) são:

- $\quad$ transparência (Disclosure);

- $\quad$ equidade (Fairness);

- $\quad$ prestação de contas (Accountability);

- $\quad$ responsabilidade corporativa.

A transparência, segundo o IBGC (2004, p. 9), é

[...] mais do que 'a obrigação de informar'. A Administração deve cultivar o 'desejo de informar', sabendo que da boa comunicação interna e externa, particularmente quando espontânea, franca e rápida, resulta um clima de confiança, tanto internamente, quanto nas relações da empresa com terceiros. A comunicação não deve restringir-se ao desempenho econômico-financeiro, mas deve contemplar também os demais fatores (inclusive intangíveis) que norteiam a ação empresarial e que conduzem à criação de valor.

Ainda segundo o IBGC (2004, p. 10), a equidade

Caracteriza-se pelo tratamento justo e igualitário de todos os grupos minoritários, sejam do capital ou das demais "partes interessadas" (stakeholders), como colaboradores, clientes, fornecedores ou credores. Atitudes ou políticas discriminatórias, sob qualquer pretexto, são totalmente inaceitáveis. 
A Prestação de Contas (accountability) é o dever que os agentes da governança têm de "prestar contas de sua atuação a quem os elegeu e responder integralmente por todos os atos que praticarem no exercício de seus mandatos" (IBGC, 2004, p. 10).

Por fim, em razão da Responsabilidade Corporativa, o Código das Melhores Práticas (IBGC, 2004, p. 10) expressa que

Conselheiros e executivos devem zelar pela perenidade das organizações (visão de longo prazo, sustentabilidade) e, portanto, devem incorporar considerações de ordem social e ambiental na definição dos negócios e operações. Responsabilidade Corporativa é uma visão mais ampla da estratégia empresarial, contemplando todos os relacionamentos com a comunidade em que a sociedade atua. A "função social" da empresa deve incluir a criação de riquezas e de oportunidades de emprego, qualificação e diversidade da força de trabalho, estímulo ao desenvolvimento científico por intermédio de tecnologia, e melhoria da qualidade de vida por meio de ações educativas, culturais, assistenciais e de defesa do meio ambiente.

Já Fabrício Macêdo (2006, p. 21), além dos princípios acima, incorpora o cumprimento das leis (compliance) e a ética (ethics) como fundamentos da governança corporativa.

Considerando-se que as escolhas realizadas pelo agente, por delegação do titular do bem ou direito, não são absolutamente previsíveis e que podem haver conflitos de interesses, a adoção de mecanismos de governança corporativa é imprescindível para a prevenção destes eventuais problemas e para a rápida correção de rumos, por meio de controle e monitoramento.

O Estado, tendo de um lado os seus cidadãos e de outro os agentes públicos, responsáveis pela gestão da coisa pública, deve garantir o pleno funcionamento de mecanismos de governança que permitam a efetiva participação e monitoramento dos cidadãos em relação às ações e decisões tomadas pelos governantes.

Os mecanismos de governança corporativa aplicados às empresas privadas em muito se assemelham aos princípios e fundamentos que regem a Administração Pública. Deveras, fundamentos como a transparência, o dever de prestar contas, a equidade, a responsabilização dos agentes, o estrito cumprimento das leis e a ética são preceitos previstos na Constituição Federal ou em outros diplomas legais e regem 
o comportamento do Administrador Público na maioria dos regimes democráticos de direito.

Sob qualquer prisma que se observe a relação entre o Estado e seus cidadãos, não é possível negligenciar quanto a prestação de contas ampla e transparente por parte dos agentes públicos, a fim de que se possibilite avaliação sobre o desempenho dos gestores públicos, norteando a ação estatal para o bem público, com eficácia e eficiência. Neste sentido, a administração pública deve pautar-se por critérios semelhantes aos da governança corporativa.

\subsection{A governança na Administração Pública}

A perfeita compreensão dos instrumentos de governança corporativa no setor público e, mais especificamente, na gestão financeira do Estado, demanda preliminarmente uma introdução sobre as profundas modificações ocorridas nas últimas décadas na administração pública.

Além da utilização de instrumentos gerenciais que permitem racionalizar e modernizar a ação administrativa do Estado, uma das mais importantes facetas das reformas que se iniciaram em meados da década de 70 (século XX), e que prosseguem ainda hoje, é a ênfase da gestão pública no atendimento aos cidadãos, não só visando à prestação de serviços públicos de qualidade, mas também para permitir maior participação destes na formulação, implantação e monitoramento das políticas públicas.

\subsubsection{Reformas da administração pública}

Historicamente, compreende-se que a Administração Pública, dentre avanços e retrocessos, atravessou e continua a percorrer uma longa trilha rumo ao seu funcionamento ideal. Assim, Luiz Carlos Bresser Pereira (2000, p. 63) esclarece que

[...] existem três formas de administrar o Estado: a 'administração patrimonialista', a 'administração pública burocrática' e a 'administração pública gerencial'. A administração patrimonialista é do Estado, mas não é pública, na medida que não visa ao interesse público. É a administração típica dos estados que antecederam o capitalismo industrial, mais particularmente das monarquias absolutas que antecederam imediatamente o capitalismo e a democracia. É a administração que 
confunde o patrimônio privado do príncipe com o patrimônio público. Sobrevive nos regimes democráticos imperfeitos através do clientelismo. A administração pública burocrática é aquela baseada em um serviço civil profissional, na dominação racional-legal weberiana e no universalismo de procedimentos, expresso em normas rígidas de procedimento administrativo. A administração pública gerencial também pode ser chamada de 'nova gestão pública' (new public management).

Cronologicamente, os gráficos abaixo dão uma ideia da evolução da gestão pública no mundo e no Brasil.

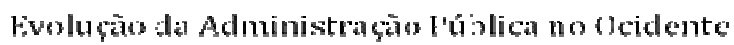

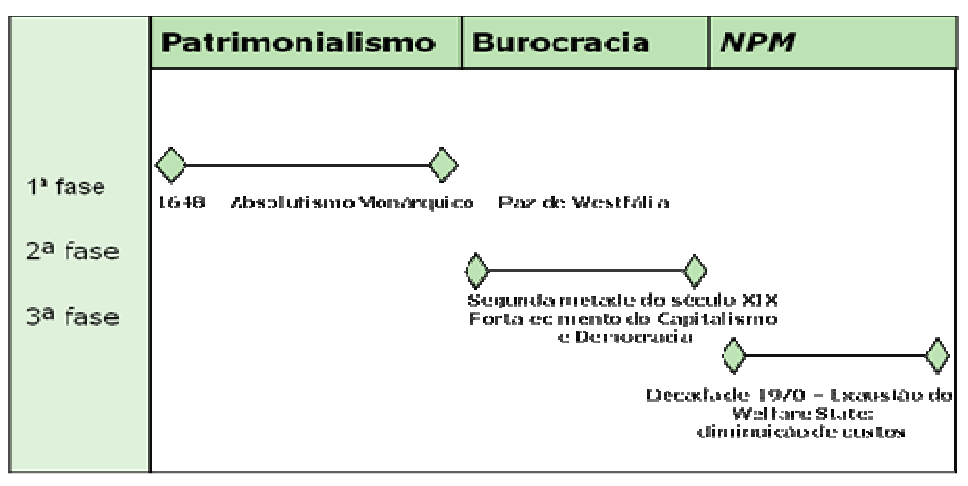

Evolução da Administração Pública Brasileira

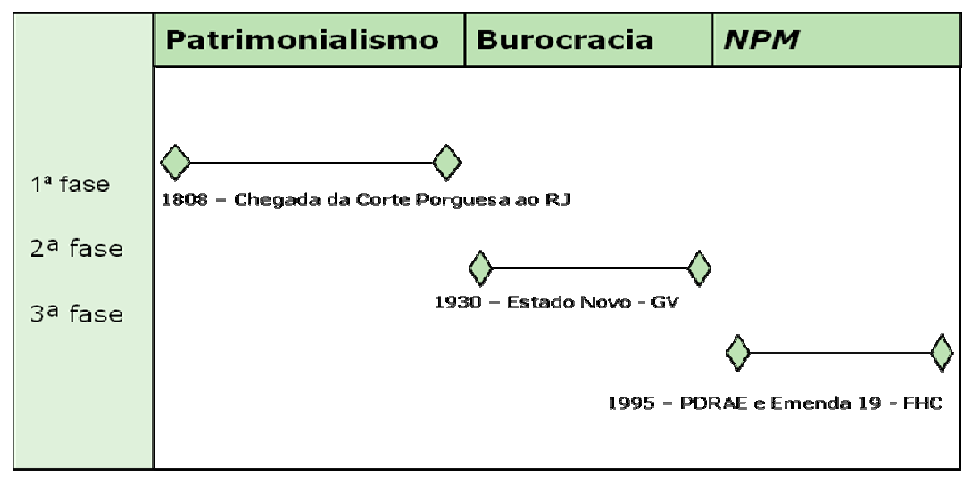

\subsubsection{Administração patrimonialista}

A administração patrimonialista, segundo Caio Marini (2004, p. 2-3), identifica-se com a gestão dos recursos públicos, que não permite diferenciar o que é interesse público e o que é interesse privado. Nessa linha, o Estado é a longa manus do soberano, que utiliza o seu poder para, egoisticamente, influenciar o comportamento dos seus súditos e, com isso, favorecer tão somente a si próprio ou a seus aliados em detrimento do interesse público. O resultado disso é a corrupção, o clientelismo e o nepotismo. 
Historicamente, pode-se afirmar que o modelo de gestão patrimonialista nem sempre foi o vigente, tomadas as devidas proporções, pela existência da República na antiga Roma, antes da sua transformação em Império. No entanto, cumpre salientar que a invasão bárbara fez sucumbir qualquer resquício que se contrapusesse ao patrimonialismo, já que neste vigia a hereditariedade. Dessa forma, os reis bárbaros acumulavam as riquezas obtidas dos seus súditos e consumiam todo o seu tesouro sem prestar contas, isto é, sem qualquer tipo de controle seja para algum órgão externo, seja para os próprios súditos.

Com isso, a administração patrimonialista foi a primeira forma de gestão do Estado Moderno e perdurou até a segunda metade do século XIX, quando foi pouco a pouco cedendo espaço para a administração burocrática ${ }^{21}$.

Em outras palavras, a decadência do modelo patrimonialista foi o resultado de um longo fortalecimento, tanto da nova burguesia e, mais tarde, do sistema capitalista, como da democracia e da sociedade civil, a qual, desde então, não mais admitiu a confusão de gastos com despesas pessoais dos monarcas com as propriamente de interesse público.

Como decorrência da história europeia, principalmente a lusitana, a administração patrimonialista no Brasil apenas teve início propriamente com a transferência da corte Imperial de Lisboa para o Rio de Janeiro. Assim, aponta Caio Marini (2004, p. 2), foi neste período que D. João VI determinou a criação dos Ministérios de Negócios do Reino, de Negócios Estrangeiros e da Guerra, e de Negócios da Marinha e Ultramar.

O mesmo Marini (2004, p. 3) relata que, nesse período inicial da administração pública brasileira, "a estrutura administrativa caracterizava-se por sua simplicidade: poucos órgãos com muita abrangência”. Ademais, Caio Marini (2004, p. 3) revela que, devido à pífia estrutura existente, o Estado foi essencial para o desenvolvimento da gestão dos negócios governamentais, a qual, segundo este autor, era marcada por um modelo agressivamente centralizado e pela inexistência de parâmetros, diretrizes e métodos científicos de gestão. Caio Marini (2004, p. 3) também denuncia que,

[...] no Brasil, o patrimonialismo fora implantado pelo Estado colonial português, quando o processo de concessão de títulos, de terras e poderes quase absolutos aos senhores de terra legará à posteridade uma prática político-adminstrativa em que o público e o privado não se distinguirão

\footnotetext{
${ }^{21}$ Cf. BRESSER-PEREIRA, Luiz Carlos. Construindo o Estado republicano: democracia e reforma da gestão pública. Tradução: Maria Cristina Godoy. Rio de Janeiro: Ed. FGV, 2009.
} 
perante as autoridades. Assim, torna-se 'natural' desde o período colonial (1500-1822), perpassando pelo período Imperial (1822-1889) e chegando mesmo à República Velha (1889-1930) a confusão entre o público e o privado em nossa sociedade. Entende-se como apanágios do patrimonialismo o paternalismo, o clientelismo e o favoritismo, característicos, ainda hoje, da política nacional; momento em que os 'coronéis' (grandes e médios fazendeiros e comerciantes) exerciam o poder de mando sobre grande parcela da população, intermediando-lhes o uso da terra, garantindo-lhes 'ocupação', 'proteção' e concedendo-lhes pequenos favores pessoais em troca de lealdade nas eleições e nas disputas políticas. Dentre as práticas do patrimonialismo, foi (e ainda é) comum a construção, com dinheiro público, de melhorias em propriedades particulares (tais como açudes, casa de veraneio, piscinas etc., ou ainda a concessão de emprego aos correligionários mais leais, sem concurso público).

\subsubsection{Administração burocrática}

Segundo conceito fornecido por Bresser Pereira (2000, p. 63), "a administração pública burocrática é aquela baseada em um serviço civil profissional, na dominação racional-legal weberiana e no universalismo de procedimentos, expresso em normas rígidas de procedimento administrativo".

Em relação ao contexto histórico em que se deu o surgimento da administração pública burocrática, informa Cecília Vescovi de Aragão (1997, p. 105) que ela

[...] veio substituir as formas patrimonialistas de gestão e ganha importância em função da necessidade de maior previsibilidade e precisão no tratamento das questões organizacionais. Apresenta-se como reação ao nepotismo e subjetivismo, que tiveram lugar nos primeiros anos da Revolução Industrial.

É preciso lembrar que o fortalecimento do modelo burocrático de gestão pública coincide com a transição do modelo econômico liberal para o modelo mais intervencionista, característico do período posterior à crise de 1929, caracterizado como Estado de Bem-Estar Social (Welfare State) ${ }^{22}$. Nessas circunstâncias, o Estado passa a ter papel mais atuante na economia e na própria prestação de serviços, acarretando aumento de seu tamanho e de suas atribuições. Esse quadro permanece até a década de 1950, quando o

\footnotetext{
${ }^{22}$ Cf. ARAGÃO, Cecília Vescovi de. Burocracia, eficiência e modelos de gestão pública: um ensaio. Revista do Serviço Público, Brasília, ano 48, n. 3, p. 105, set./dez. 1997.
} 
modelo intervencionista do Welfare State começa a dar sinais de esgotamento, com o início das crises fiscais e com o superdimensionamento do aparelho estatal.

Em seguida, nas décadas de 70 e 80 do século XX, esclarece Cecília Aragão (1997, p. 105) que

[...] a tendência neoliberal passa a enfatizar a fragilidade da solução estatal para garantia do bem-estar social e da estabilidade econômica, preconizando a solução de mercado e fundamentando a ideia de Estado mínimo, com redução de sua estrutura administrativa. O cenário econômico engloba mudanças nos padrões de competição, em função da alteração do paradigma tecnológico, assim como a intensificação da globalização financeira. Aguça-se o movimento de esgotamento do padrão de acumulação fortalecido no pós-guerra.

Por conseguinte, verifica-se que a reforma burocrática da administração pública, de inspiração weberiana, é um verdadeiro marco na evolução do trato estatal em relação aos interesses públicos. Nesse diapasão, Bresser Pereira (2000, p. 64) observa e critica que,

[...] através da Reforma Burocrática, ocorrida na Europa no século passado, nos Estados Unidos no início deste século, e no Brasil nos anos 30, nos quadros do liberalismo, mas não da democracia, estabeleceu-se a administração pública burocrática. A Reforma Burocrática foi um grande avanço ao romper com o patrimonialismo e estabelecer as bases para o surgimento da administração profissional. Foi uma verdadeira reforma porque se antepôs à administração patrimonialista e criou as instituições necessárias à racionalização burocrática e, mais especificamente, ao surgimento de uma burocracia profissional.

Caio Marini (2004, p. 5), por sua vez, noticia que

[...] o modelo de administração burocrática foi introduzido no Brasil a partir da segunda metade dos anos 30, na tentativa de enfrentar os problemas decorrentes da forte cultura patrimonialista dominante. O país vivia um contexto caracterizado por um modelo de desenvolvimento autóctone centrado na industrialização e um tipo de Estado com forte orientação nacionalista, centralizador e baseado no estatismo dirigista.

Conforme Caio Marini (2004, p. 7), uma das primeiras tentativas de reforma administrativa no Brasil foi a edição do Decreto-Lei 200, em 1967, cujas características marcantes eram propiciar mais agilidade ao aparelho estatal, bem como 
propiciar a descentralização administrativa por meio do fortalecimento da administração indireta.

Ainda segundo Caio Marini (2004, p. 8), o equívoco cometido com a edição do Decreto-Lei 200 foi flexibilizar a administração sem, contudo, fortalecer as estruturas de controle, "enfraquecendo desta forma, o núcleo central do aparelho estatal responsável pela formulação das políticas públicas. De certa forma prevaleceu a máxima da flexibilização pela flexibilização". A consequência desta iniciativa foi - ao mesmo tempo que permitiu a utilização de formas mais flexíveis de gestão - a disseminação do mau uso de tais práticas, obrigando a reversão da tendência de centralização.

Em seguida, quanto ao período militar ${ }^{23}$, ilustra Marini (2004, p. 9) que foi criada, durante a década de 70 do século passado, a "SEMOR - Secretaria da Modernização, incorporada ao Ministério do Planejamento que passou a receber a denominação de Ministério do Planejamento e Coordenação Geral, com a responsabilidade de integrar o tripé: Planejamento - Orçamento - Gestão", que teve relevante papel na reorganização das áreas de recursos humanos e desenvolvimento organizacional.

Inúmeras foram as iniciativas de reforma da gestão pública nas décadas de 1970 e 1980. Uma das que gozou de maior popularidade foi a criação do Programa Nacional de Desburocratização ${ }^{24}$, pelas mãos de Hélio Beltrão, que viria a ser o Ministro da Desburocratização. A ideia central era a simplificação burocrática, inclusive com a redução de exigências formais da máquina administrativa para os cidadãos.

Finalmente, Marini (2004, p. 10) evidencia que, após o final da década de 70, “as atividades de gestão pública tiveram diversos destinos conforme o humor dos 'reformadores de organograma' de plantão (SEAD, SAF, Ministério do Trabalho e da

\footnotetext{
${ }^{23}$ Ainda em relação à estrutura da burocracia durante o período militar, Gilda Portugal Gouvêa (GOUVÊA, Gilda Portugal. Burocracia e elites burocráticas no Brasil. São Paulo: Paulicéia, 1994. p. 149) contextualiza que, “[...] com o golpe de 1964, o 'grupo' estruturalista foi derrotado, e as novas gerações de técnicos que chegaram a Brasília, principalmente após a criação do Banco Central, não foram mais expostas àquela dualidade de pensamento, pois a orientação monetarista imprimiu as diretrizes da política econômica pelas duas décadas seguintes. $\mathrm{Na}$ realidade, pouco a pouco, a burocracia ligada aos órgãos do Governo da área econômica foi perdendo o seu elemento político unificador que era o projeto naciona1-desenvo1vimentista (mesmo dentro de posições pró ou contra), e este espírito passa a ser substituído exclusivamente por um componente supostamente neutro, ou seja, o conhecimento técnico. Esta lógica se baseia na crença de que a solução dos problemas depende de medidas que partam de um diagnóstico imparcial e de recomendações que se fundamentem num profundo e detalhado conhecimento da matéria, elaborado portanto por especialistas. Dentro desta lógica, o único critério valorativo que se admite é a defesa do interesse público."

${ }^{24}$ Cf. MARINI, Caio. Gestão pública no Brasil: temas preservados e temas emergentes na formação da agenda. In: CONGRESSO DA ASSOCIAÇÃO DE ESTUDOS BRASILEIROS BRASA - Brazilian Studies Association, 7., p. 9, jun. 2004. Disponível em: <http://institutopublix.com.br/docs/brasabrasil.pdf>. Acesso em: 01 jul. 2009.
} 
Administração, SAF outra vez, MARE, SEAP e agora SEGES outra vez de volta ao recanto original: o Planejamento)".

\subsubsection{Administração gerencial}

As décadas de 1970 e 1980 foram marcadas pelo agravamento das crises econômicas e fiscais do Estado. $\mathrm{O}$ aumento das funções do Estado, as crescentes demandas da sociedade e o ambiente de internacionalização, que mais tarde iria desaguar na globalização da economia, colocaram a administração pública em crise aguda. Situa Maria das Graças Rua (1997, p. 141) que,

[...] embora a crise econômica e a crise fiscal pudessem ser contornadas com a redefinição do papel do Estado na economia e com o corte de políticas sociais, o mesmo não se aplicava à crise de governabilidade e aos desafios da globalização. Na verdade, não apenas o Estado passou a contar com menos recursos, mas também passou a dispor de menos poder efetivo. Logo, a solução não poderia se limitar à esfera econômica, mas deveria se estender ao modelo político-administrativo.

Dessa maneira, as mudanças indispensáveis "impunham a presença de quadros criativos, flexíveis e capazes de inovar, competitivos e comprometidos em melhorar o seu desempenho, orientados para a sociedade em lugar de auto-referidos, dotados da motivação resultante da capacidade de acreditar no que estivessem realizando" (Rua, 1997, p. 142).

Acredita-se que, em função da necessidade de aplicar novas medidas que modernizassem a administração pública, ainda que através de tentativas e erros, a administração pública gerencial surgiu.

A administração pública gerencial, também conhecida por nova gestão pública (NGP) ou "new public management" (NPM) tem como objetivo, nas palavras de Bresser Pereira (2006, p. 36),

[...] construir um Estado que responda às necessidades de seus cidadãos; um Estado democrático, no qual seja possível aos políticos fiscalizar o desempenho dos burocratas e estes sejam obrigados por lei a lhes prestar contas, e onde os eleitores possam fiscalizar o desempenho dos políticos e estes também sejam obrigados por lei a lhes prestar contas. Portanto, é essencial uma reforma política que dê maior legitimidade aos governos, o 
ajuste fiscal, a privatização, a desregulamentação e uma reforma administrativa que crie os meios de se obter uma boa governança.

Assim, a origem da administração pública gerencial, como afirmado, decorre da importação de mecanismos utilizados pelos agentes privados em suas atividades para obter o lucro.

Nessa linha, alguns fundamentos da administração privada foram adaptados para implementação na gestão pública. Trata-se, então, de uma concepção econômica, com forte ênfase na eficiência administrativa, na avaliação de custos, na produtividade e na definição do cidadão como um cliente a ser atendido com rapidez e qualidade.

Mark Bevir et al. (2003, p. 1-2) afirmam que

[...] o movimento da NGP teve início na década de 70, e os primeiros participantes foram o Reino Unido, com a primeira ministra Margaret Thatcher, e nos Estados Unidos com o governo municipal de Sunnyvale, na Califórnia. Na sequência, juntaram-se ao movimento os governos da Nova Zelândia e Austrália.

O estabelecimento de instrumentos de governança na gestão pública está intimamente ligado à instituição de novos modelos gerenciais. Nesse ponto, cumpre revisitar as lições de Bresser Pereira (2006, p. 242-3), que traçam algumas características da NGP:

- descentralização do ponto de vista político, transferindo-se recursos e atribuições para os níveis políticos regionais e locais;

- descentralização administrativa, através da delegação de autoridade aos administradores públicos, transformados em gerentes cada vez mais autônomos;

- organizações com poucos níveis hierárquicos, ao invés de piramidais;

- pressuposto da confiança limitada e não da desconfiança total;

- controle a posteriori, ao invés do controle rígido, passo a passo, dos processos administrativos;

- administração voltada para o atendimento do cidadão, ao invés de autorreferida. 
É possível concluir que as reformas administrativas têm escopo maior do que a mera reorganização administrativa. Em verdade, as transformações na gestão pública são a única resposta possível para a mudança nas relações entre o Estado e a sociedade. Trata-se, segundo Bresser Pereira (2006, p. 242), de "legitimação da burocracia perante as demandas da cidadania”.

No Brasil, como reporta Maria da Graça Rua (1997, p. 143), a administração gerencial também teve como característica a tentativa de compatibilizar a aplicação dos métodos do setor privado ao público, paralelamente ao que ocorria no mundo.

Nesse sentido, pondera Raimundo Augusto Cardoso de Miranda (2004, p. 8),

[...] faz-se necessário o desenvolvimento das instituições no sentido de ampliar os mecanismos de 'governança', que pode ser vista como o exercício da autoridade econômica, política e administrativa para gerenciar um país em todos os níveis. Compreende os mecanismos, processos e instituições por meio dos quais os cidadãos e grupos articulam seus interesses, exercitam seus direitos legais, cumprem com suas obrigações e mediam suas diferenças.

As reformas direcionam a administração à maior flexibilidade para a participação de entidades privadas e da sociedade civil. Além disso, a ênfase passa do procedimento para o resultado. Além dos objetivos econômicos de otimização dos recursos financeiros, busca-se a eficiência dos serviços públicos e a ampliação da participação social. $^{25}$

A reforma gerencial da administração pública, durante o Governo Fernando Henrique, iniciou em 1995, com o Plano Diretor da Reforma do Aparelho do Estado (PDRAE), ocasião em que o Poder Executivo submeteu ao Congresso uma Emenda Constitucional ao capítulo sobre Administração Pública na Constituição de 1988.

Porém, conforme lembra Bresser Pereira (2002, p. 19),

[...] muitas mudanças institucionais não requereram emendas constitucionais formais, como foi o caso da criação das três instituições básicas da reforma, as agências reguladoras, as agências executivas e as

\footnotetext{
${ }^{25}$ Cf. MOISÉS, Rodrigo Gabriel. Reforma do estado e os novos modelos. Revista Eletrônica Faculdade
} Montes Belos, Goiás, v. 1, n. 2, p. 51-61, nov. 2005. 
organizações sociais, e, também, uma política eficaz de remuneração para servidores públicos, recrutamento e seleção anuais de novos dirigentes para as carreiras de Estado e a eliminação de privilégios excessivos que os servidores públicos estatutários tinham adquiridos pela lei do Regime Jurídico Único.

Ainda de acordo com o Bresser (2002, p. 20),

[...] a reforma de 1995 adotou uma abordagem gerencial da gestão pública e uma abordagem social-democrática e social-liberal do papel do Estado. É gerencial porque extrai a inspiração da gestão de empresas privadas, e porque adota a promoção de autonomia e responsabilidade das agências públicas como estratégia básica para atingir mais eficiência e qualidade. É democrática, porque pressupõe a governança democrática, faz do controle social pela sociedade civil uma forma principal de responsabilidade política, e requer transparência das agências públicas. É social-democrática, porque afirma o papel do Estado de garantir a proteção eficaz dos direitos sociais. É social-liberal, porque acredita no mercado como um excelente agente de alocação de recursos e vê a terceirização de serviços e a competição controlada como excelentes ferramentas de responsabilidade.

Assim, as reformas gerenciais iniciadas na década de 1990 orientaram o Poder Público para alguns princípios que fortalecem a governança pública, a saber: enfoque no resultado; autonomia e responsabilização; construção de boas parcerias; trabalho em rede; gestão da informação; transparência, diálogo público e avaliação. ${ }^{26}$

Neste contexto, fortalecer a governança é promover a capacidade do governo de formular e implementar políticas públicas e de decidir quais as mais adequadas. Para isto, são necessários o fortalecimento da inteligência estratégica governamental e a adoção de novas práticas de interlocução e participação.

\subsubsection{Experiências Estrangeiras}

A governança no setor público tem sido objeto de muitos estudos e experiências e o tema está na agenda de diversos países, além de estar intimamente relacionado com as reformas na gestão pública surgidas nos últimos 20 anos. A necessidade de reformulação da gestão pública e os desafios econômicos e sociais com que

\footnotetext{
${ }^{26}$ Cf. BRESSER-PEREIRA, Luiz Carlos. Reforma da nova gestão pública: agora na agenda da América Latina, no entanto... Revista do Servidor Público, ano 53, n. 1, jan./mar. 2002.
} 
se defrontam os governos exigem instrumentos mais eficazes e transparentes, o que vem sendo alcançado com a adoção de práticas de governança.

Das inúmeras experiências ao redor do mundo ${ }^{27}$, alguns países ganharam maior destaque, sobretudo porque foram precursores na reforma do setor público e também na adoção de práticas de governança pública. Bresser Pereira (2006, p. 242) cita que os países que sofreram reformas mais profundas na gestão pública, a partir da década de 1980, foram a Austrália, a Nova Zelândia, o Reino Unido e, por fim, os Estados Unidos da América, cuja característica principal é a prevalência das experiências de inovação da gestão entre os entes federados, com a adesão tardia e menos intensa do governo central.

\subsubsection{Austrália}

A Austrália é um dos países que mais investiram, nos últimos 30 anos, na reformulação do serviço público e na implementação de novas ferramentas de gestão. Essa preocupação com a qualidade do serviço público esteve sempre acompanhada da utilização de mecanismos de governança.

As empresas públicas australianas, desde 1996, foram submetidas a um padrão de boas práticas de governança corporativa, nos moldes do que já era exigido das companhias privadas (BUTLER, 1999, p. 2). Também em 1996 foi editada, pelo governo federal australiano, a publicação "Ethical and Values in the Australian Public Service", reforçando os valores de probidade, integridade e honestidade na gestão federal dos serviços públicos (BUTLER, 1999, p. 3).

Os novos padrões de governança exigidos na administração pública australiana são, em verdade, resultado de uma profunda reflexão dos estudiosos e profissionais da gestão pública, o que acabou concretizado em uma grande quantidade de estudos e documentos que tratam do assunto e que ajudam a pautar o comportamento do administrador público daquele país. Vale salientar que os escritórios de auditoria externa, tanto de âmbito federal (ANAO - Australian National Audit Office), como de alguns dos

\footnotetext{
${ }^{27}$ Cf. (1) Oscar Oszlak (OSZLAK, Oscar. Building capacities for governance in Argentina. Asian Review of Public Administration, v. 11, n. 1, Jan./June 2000), sobre governança na Argentina; (2) Elizabeth Watson (WATSON, Elizabeth. Public-sector corporate governance: British Columbia's best-practices reforms. Ivey Business Journal, Mar./Apr. 2004), sobre experiências de governança na província de British Columbia, no Canadá e também o orçamento do Canadá, que demonstra o grau de transparência e accountability voltado aos cidadãos; (3) sobre experiências na Holanda, DAR-Government Audit Policy Directorate/The Netherlands Ministry of Finance. Government Governance: Corporate Governance in the public sector, why and how? Hague: DAR, 2000. Disponível em: <http//www.minfin.nl>. Acesso em: 14 out. 2009.
} 
entes federados (NSWAO - New South Wales Audit Office e o QAO - Queensland Audit Office), têm papel fundamental na disseminação da cultura de governança na gestão pública australiana. Esses escritórios de auditoria, cuja função precípua é exercer o controle externo da administração pública, enfatizam, no exercício de suas atividades, a avaliação de performance da gestão, a transparência, a prestação de contas, a liderança e a avaliação de riscos. Mais do que isto, os escritórios de auditoria produzem vasto material técnico acerca de temas relacionados à governança ${ }^{28}$, disseminando essa cultura entre gestores públicos e a própria sociedade.

As transformações do setor público australiano e, especialmente, a adoção de instrumentos de governança, que visam à prestação de contas, eficiência e transparência, são explicitados em termos de princípios por meio de legislação específica (ANAO, 1999, p. 5). É o caso do Financial Management and Accountability Act, de 1997, do Auditor-General Act, também de 1997, e do Public Service Act.

Além da legislação, a moldura institucional de governança é formada pelos sistemas de controle interno, pela auditoria externa, pelos códigos de ética e por sistemas de gestão financeira e de recursos (ANAO, 1999, p. 6).

Embora as iniciativas tenham sido inicialmente dirigidas às agências públicas que tenham orçamento próprio, o certo é que os princípios gerais de governança foram estendidos a todas as esferas da administração pública, seja ela direta ou indireta (Ryan, Ng, 2000, p. 15).

Os vários documentos que tratam da governança no setor público australiano fundamentam-se em princípios basilares de comportamento para o gestor público. Tais princípios, claramente definidos nos relatórios da ANAO (1997 e 1999) refletem a preocupação com a gestão transparente, segura e eficaz. São eles: (1) liderança; (2) ambiente administrativo; (3) administração de risco; (4) monitoramento; (5) prestação de contas e (6) legislação ${ }^{29}$.

\footnotetext{
${ }^{28} \mathrm{Cf}$. ANAO: (1) Applying principles and practice of corporate governance in budget funded agencies (1997) e (2) Corporate governance in commonwealth authorities and companies (1999); NSWAO: Performance audit report on corporate governance (1997a, 1997b) e QAO: Corporate governance: beyond compliance (QAO, 1999).

${ }^{29}$ Princípio introduzido no relatório de 1999 (ANAO, Australian National Audit Office. Corporate governance in commonwealth authorities and companies. Discussion Paper, 1999. Disponível em: $<$ http://www.anao.gov.au>. Acesso em: 03 jul. 2009).
} 
A liderança é qualidade necessária ao gestor público, sendo essencial o papel do dirigente na condução das políticas públicas. $\mathrm{O}$ ambiente administrativo, por sua vez, deve prever a clara definição de papéis entre os agentes, além das responsabilidades de cada um. A gestão pública também deve estar amparada por eficiente sistema de planejamento e controle. A gestão de riscos, definida como o processo de identificação, análise e mitigação de riscos capazes de obstar o alcance dos objetivos, deve ainda pautar a gestão pública. $\mathrm{O}$ administrador público deve também monitorar permanentemente a execução e implementação das políticas públicas, por meio de revisões periódicas, garantindo a contínua perseguição dos objetivos e metas. A prestação de contas é dever de qualquer gestor público e princípio fundamental de governança. Por fim, tais pilares só serão efetivos se estabelecidos por meio de legislação clara e inequívoca (Ryan, Ng, 2000, p. 15-16).

A transposição das teorias de governança corporativa aplicadas ao setor privado diretamente ao setor público não é adequada, como visto, tendo em vista uma série de peculiaridades e diferenças entre os objetivos, os agentes e a amplitude de cada uma das esferas. Na experiência australiana tal dificuldade foi considerada, sendo certo que as práticas adotadas levam em conta as características da administração pública, o que se verifica com clareza nos próprios princípios norteadores propostos pela ANAO e pelas demais autoridades australianas. De fato, o NSWAO’s Performance Audit Report on Corporate Governance reconhece a maior complexidade na prestação de contas no setor público, bem como considera os diferentes objetivos e estruturas de cada ente público, o que por si só já se afigura como absoluta incompatibilidade com o setor privado. Conforme observam Christine Ryam e Chew Ng (2000, p. 16), enquanto a governança corporativa na iniciativa privada tem mais foco no aspecto da conformidade ${ }^{30}$, no setor público a tendência é a ênfase na performance, dimensão esta que inclui a gestão de riscos e a liderança. Realmente, o NSWAO’s Performance Audit Report on Corporate Governance reforçou a ideia de que liderança e a administração de risco são elementos fundamentais da estrutura global de governança corporativa.

O governo australiano ainda possui, no âmbito de sua política de cooperação e ajuda a países em desenvolvimento, programas específicos para a governança pública. Patrícia Lyon (2000, p. 88) descreve as quatro áreas estratégicas em que o

\footnotetext{
${ }^{30}$ Para os autores, "conformance", qual seja, o foco no ambiente administrativo, no monitoramento e na prestação de contas.
} 
programa australiano da Australian Agency for International Development atua, auxiliando países a estabelecer um sistema de governança pública, sempre sob a premissa de que tais ferramentas são fundamentais para o desenvolvimento econômico e social dessas nações. As quatro áreas estratégicas do programa de auxílio ao desenvolvimento são: gestão econômica e financeira; gestão do setor público; direito e justiça e sociedade civil. Vale dizer que, com referência à gestão econômica e financeira, um dos aspectos abrangidos pela política de parceria da agência australiana é a administração financeira do poder público, onde um dos pontos fortes do programa é transferência das experiências e tecnologia do governo australiano nas áreas de contabilidade pública, planejamento orçamentário e auditoria.

Além dos aspectos relacionados diretamente à gestão financeira, o governo australiano auxilia os países com reformas na estrutura governamental, na legislação correlata e na capacitação de políticos e servidores públicos, tendo como foco a gestão de serviços públicos voltados inteiramente ao interesse público.

Há também iniciativas para disseminar a implementação de mecanismos de boa governança, como, por exemplo, o manual de boas práticas de governança, editado pela CPA Austrália ${ }^{31}$, voltado para os governos locais. O material indica de forma prática quais são os princípios da boa governança, quais as vantagens de sua implementação e quais os passos para sua adoção (CPA Austrália, 2005).

\subsubsection{Nova Zelândia}

A Nova Zelândia, assim como outros países ao redor do mundo, promoveram reformas no setor público, motivadas pelo aumento dos gastos públicos e a necessidade de dar mais eficiência e eficácia às políticas públicas (Scott et al., 1990, p. 142-143) e a adesão a práticas de governança, portanto também esteve acompanhada de profundas reformas na gestão pública.

A gestão pública na Nova Zelândia também sofreu com os mesmos males que a maioria dos países ocidentais no pós-guerra, o que culminou em um quadro de grande ineficiência, centralização e descontrole do Estado (Richardson, 2006. p. 216).

\footnotetext{
${ }^{31}$ CPA Austrália (Certified Public Accountants) é entidade que agrega profissionais, por ela certificados, que atuam nas áreas da gestão e contabilidade públicas.
} 
Em meados da década de 1980 o governo da Nova Zelândia iniciou uma grande reforma do Estado, transferindo atividades de prestação de serviços para empresas pertencentes ao Estado, mas que gozam de maior agilidade e flexibilidade ${ }^{32}$ (Scott et al. 1990, p. 143-144), racionalizando as atividades estatais remanescentes por meio de nova moldura legal $^{33}$ (Scott et al., 1990, p. 159). Mais do que isto, o processo culminou com a privatização de várias empresas estatais atuantes em setores econômicos onde o setor privado teria mais eficiência, gerando recursos para o ajuste fiscal necessário e reduzindo o peso do Estado (Scott et al., 1990, p. 152-153).

Os objetivos da reforma, segundo Ruth Richardson (2006, p. 217) foram:

- melhorar a relação custo-eficiência na produção de bens e serviços pelo setor público;

- melhorar a qualidade desses bens e serviços;

- tornar a atuação do setor público, como provedor de bens e serviços, mais sensível às necessidades dos consumidores;

- dar aos representantes eleitos maior controle sobre a utilização do dinheiro dos contribuintes;

- $\quad$ aumentar a transparência do setor público e

- $\quad$ restringir os gastos públicos em geral, dentro dos limites de uma administração fiscal responsável.

Nesse sentido, o processo de reformas do setor público na Nova Zelândia, como resume Bresser Pereira (1998, p. 55), foi voltado para "aumentar a eficiência" e "melhorar a accountability (responsabilização) dos serviços públicos em relação ao Executivo e ao Parlamento, embora muita preocupação tenha sido expressa acerca dos custos sociais implicados na manutenção de um setor público ineficiente".

Uma das peculiaridades do processo de reestruturação dos serviços públicos naquele país foi a aplicação, na primeira fase de reformas ${ }^{34}$, de princípios da gestão empresarial para a gestão pública. June Pallot (1998, p. 2), embora aponte a

\footnotetext{
${ }^{32}$ Também denominadas SOE's - "State-Owned enterprises"

33“"New Public Finance Act", aprovada pelo Parlamento em julho de 1989 e o "State Sector Act", de abril de 1988.

${ }^{34}$ June Pallot (PALLOT, June. New public management reform in New Zealand: the collective strategy phase. International Public Management Journal, v. 1, n. 1, p. 1-18, 1998) denomina esta primeira fase de "managerialist phase", que vai de 1978 a 1995, caracterizada pela adaptação de práticas da gestão de empresas para a gestão pública.
} 
necessidade de considerar as peculiaridades entre a administração pública e privada, relaciona algumas práticas gerenciais que são próprias da gestão privada, mas que, adaptadas à gestão pública, possibilitaram a melhor eficiência na prestação de serviços públicos. A partir de 1992, Pallot (1998, p. 3) aponta para a última fase de mudanças na gestão pública da Nova Zelândia, com ênfase na estratégia global do governo e foco nas políticas de longo prazo. Para Pallot (1998, p. 3), a contabilidade teve um papel importante na introdução dessa nova fase da gestão pública na Nova Zelândia, com mudanças na administração contábil e financeira que permitiram elevar o grau de transparência e accountability.

A década de 1980 foi marcada por crises fiscais na Nova Zelândia (Scott et al, 1990, p. 139), que tinha também sua gestão pública regulada por diplomas legais desatualizados e incapazes de promover as mudanças necessárias. Além das alterações legislativas já citadas, era necessária uma norma que estabelecesse princípios gerais de responsabilidade na gestão das finanças públicas. A par dessa necessidade, o Parlamento da Nova Zelândia aprovou, em 1994, sua Lei de Responsabilidade Fiscal ${ }^{35}$, que fixou princípios gerais que devem nortear o gestor público em relação às finanças. Dentre os princípios de gestão responsável, que acabaram por inspirar também o legislador brasileiro, como se verá mais adiante, destacam-se (1) a prudência e a razoabilidade no trato com as dívidas públicas e com os riscos fiscais; (2) o equilíbrio entre receitas e despesas e (3) a adoção de políticas consistentes para controlar a estabilidade das alíquotas de impostos ${ }^{36}$. Porém, a Lei de Responsabilidade Fiscal da Nova Zelândia tem, como uma de suas características mais marcantes, a preocupação com a transparência, a prestação de contas e a proteção do interesse público, caracterizando-a como um importante instrumento de governança pública. Apenas para ilustrar, Ruth Richardson (2006, p. 226) relata a existência de sofisticados relatórios financeiros na Nova Zelândia. Além de relatórios por setor estatal, contabilizados pelo regime de competência, a Nova Zelândia é o único país que elabora anualmente um balanço consolidado para o setor público.

\footnotetext{
${ }^{35}$ Fiscal Responsability Act.

${ }^{36}$ Cf. CAMARGO, Guilherme Bueno de. A guerra fiscal à luz da Lei Complementar 101, de 4 de maio de 2000. 2005. Dissertação (Mestrado) - Faculdade de Direito, Universidade de São Paulo, São Paulo, 2005.
} 


\subsubsection{Reino Unido}

As reformas do setor público britânico iniciaram-se no período da gestão de Margareth Thatcher, com a adoção de técnicas gerenciais (Abrucio, 2006, p. 179). Porém, como aponta Kate Jenkins (2006, p. 201), várias reformas foram tentadas desde o último século, muito embora as mais relevantes tenham sido levadas a cabo nos últimos 30 anos. $^{37}$

De fato, o período mais importante das reformas ocorreu durante o governo conservador, eleito em 1979. Tais mudanças tinham como foco a racionalização e a modernização do serviço público britânico, por meio da redução da máquina estatal e da implantação de instrumentos de controle do desempenho. Trata-se do que Fernando Abrucio (2006, p. 182) chamou de gerencialismo puro, cuja preocupação era tornar a administração pública mais parecida com a gestão privada. Um dos instrumentos característicos desse processo, citado por Bresser Pereira (1998, p. 53), foi o "Efficiency Unit", órgão que cuidava de avaliar a eficiência do serviço público britânico. Essa unidade, como relata Kate Jenkins (2006, p. 205), produziu em 1986 um relatório chamado “Aperfeiçoando o gerenciamento no governo: os próximos passos", em que se iniciou um processo de descentralização administrativa com delegação às agências executivas da competência de prestar o serviço público, com ênfase na qualidade e eficiência ${ }^{38}$ (Jenkins, 2006, p. 205).

Essa abordagem sofreu críticas e evoluiu para um novo patamar, em que a eficiência deveria ser pensada em termos de qualidade dos serviços públicos prestados à sociedade (Bento, 2003, p. 90).

Prosseguindo nessa evolução, o governo britânico lança, na gestão do Primeiro Ministro John Major, a Carta de Compromisso com os Cidadãos ${ }^{39}$, que, como relata Leonardo Bento (2003, p. 90-91),

\footnotetext{
${ }^{37}$ Jenkins (JENKINS, Kate. A reforma do serviço público no Reino Unido. In: BRESSER-PEREIRA, Luiz Carlos; SPINK, Peter. Reforma do Estado e administração pública gerencial. 7. ed. São Paulo: FGV, 2006. p. 201) ressalta a Comissão Real estabelecida em meados dos anos 60, cujo relatório final, denominado "Relatório Fulton”, "deixou subsídios significativos para o serviço público moderno".

${ }^{38}$ A autora aponta que atualmente quase $75 \%$ do contingente de servidores públicos britânicos atua nas 108 agências executivas, que podem ser pequenas unidades ou grandes centros com até 40 mil servidores (2006, p. 205-213).

39" Citizen's Charts". Jensen (JENKINS, Kate. op. cit., p. 213), conta que hoje há mais de 50 cartascompromisso publicadas, definindo metas e monitoramento dos serviços públicos por área.
} 
[...] consiste na declaração de metas e serviços visados pelo governo relativamente ao cidadão, estendendo ao público o direito de acesso e controle do sistema de gerenciamento de informação desenvolvido nas primeiras etapas da reforma administrativa inglesa. Trata-se de avaliar os programas sociais e as políticas públicas segundo informações prestadas pelos seus próprios "clientes".

Kate Jensen (2006, p. 213) relata que os sinais de melhoria na prestação de serviços públicos são claros, tanto em rapidez como em eficiência e honestidade.

Com relação à adoção de práticas de governança, o Relatório Cadbury, de 1992, resultado do trabalho do Cadbury Committee, apesar de dirigido às corporações privadas do Reino Unido, trouxe inspiração para que se iniciasse uma reflexão sobre a governança no setor público.

Destarte, ao estabelecer alguns princípios para a governança no setor privado, quais sejam, (1) a transparência, (2) a accountability e (3) a integridade, o relatório demonstrou que seria possível a abordagem deste tema na gestão pública. Assim, foi inspiração para que o British Chartered Institute of Public Finance and Accountancy (CIPFA), em 1995, lançasse as premissas para a governança no setor público, aplicando os mesmos princípios previstos no Cadbury Report, mas de forma adequada às peculiaridades da administração pública.

Atualmente, a prestação de serviços públicos na Grã-Bretanha tem como referência as recomendações de good governance estabelecidas em um documento (CIPFA, 2004) que indica princípios como transparência, clareza, rígido estabelecimento dos papéis e responsabilidades dos agentes públicos, controle de performance, gestão de riscos e ampla prestação de contas à sociedade.

\subsubsection{Estados Unidos da América}

As reformas gerenciais na administração pública norte-americana iniciaram-se tardiamente em relação à Grã-Bretanha, Austrália e Nova Zelândia. Há várias razões a explicar esse atraso. Bresser Pereira (1998, p. 61), citando Pollit (1993) ${ }^{40}$, aponta, como uma possível causa, o grau de extremo pluralismo político característico do sistema

${ }^{40}$ POLLIT, Christopher. Managerialism and the public service. 2. ed. Oxford: Blackwell, 1993. 
norte-americano, em contraste com a concentração de poder político no caso britânico. Outra possível razão, levantada por Richard Stilmann II (2003, 19-21) é a própria tradição da formação do povo norte-americano, que originariamente escapou da opressão do Velho Mundo para ser livre em um mundo novo. Essa, segundo o autor, é a gênese do liberalismo norte-americano e a crença da sociedade contra um Estado controlador e centralizador.

A despeito da fragilidade gerencial nos serviços públicos, a partir da década de 1970 o Estado norte-americano também começou a sofrer os impactos das transformações globais de âmbito econômico e social, que exigiram do Estado maior atuação, especialmente para fazer face aos direitos de bem-estar conquistados pela população. É a partir daí que também o setor público norte-americano é obrigado a promover reformas. Fernando Abrucio (2006, p. 179) aponta que foi a partir da década de 1970 que a crise do Estado se acentuou, com dificuldades fiscais e problemas na gestão pública. Nesse quadro, segundo o autor (2006, p. 179), "o modelo gerencial, importado da iniciativa privada, foi o fio condutor das reformas". De fato, a crise do Estado norteamericano, iniciada na década de 1970, acentuou-se, ficando crítica em 1990 (Osborne e Gaebler, 1997, p. 1), tornando as mudanças indispensáveis.

Uma das características mais marcantes das mudanças gerenciais na administração pública norte-americana é que, ao contrário da maioria dos demais países que as empreenderam, ela se deu inicialmente nas esferas descentralizadas da federação, em especial nos municípios e condados, como relata Bresser Pereira (2006, p. 243). De fato, municípios e regiões dos Estados Unidos da América foram responsáveis pelas experiências pioneiras de reforma administrativa do setor público daquele país. David Osborne e Ted Gaebler (1997) relatam várias experiências de sucesso espalhadas pelo país, que acabaram inspirando o governo federal, na gestão Clinton ${ }^{41}$, a adotar práticas gerenciais na administração pública federal. Osborne e Gaebler (1997, p. 3) citam o exemplo da cidade de Visalia, na Califórnia, que adotou nos anos 1980 um sistema mais flexível de orçamento e planejamento estratégico, que permitiu economia de recursos e maior agilidade. Outro exemplo eloquente trazido por Osborne e Gaebler (1997, p. 154) é o da cidade de Sunnyvale, na Califórnia. Lá iniciou-se o processo de transformação pela

\footnotetext{
${ }^{41}$ BRUDNEY, Jeffrey L.; WRIGHT, Deil S. Revisiting administrative reform in the American States: the status of reinventing government during the 1990s. Public Administration Review, v. 62, n. 3, p. 353, May/Jun. 2002 relatam que somente em 1993, após a obra de Osborne e Gaebler (original de 1992), portanto, é que o governo Clinton iniciou um processo de reforma da gestão pública nacional, com o "National Performance Review", que incorporou vários conceitos trazidos no livro.
} 
ênfase no desempenho dos serviços públicos, com a implantação de mecanismos para avaliação capazes de aferir os resultados do trabalho de cada uma de suas unidades, recompensando seus administradores com base em seus sucessos, revelando, assim, uma das características dos modelos de gestão norte-americanos: a valorização da meritocracia.

Essa característica de valorização da meritocracia é apontada por Richard Stillman II (2003, p. 30), que acredita na ocorrência de quatro vertentes na reforma do serviço público norte-americano, todas implícitas nos argumentos das reformas administrativas correntes: (1) a meritocracia, focada na promoção da efetividade organizacional das instituições públicas para o bem público geral; (2) a eficiência, que visa a produzir mais retorno com menos custos, como nos negócios; (3) a participação do setor privado, com a meta de livrar os administradores públicos de formalidades burocráticas e (4) a participação, com o objetivo de incentivar os cidadãos e alcançar a governança voltada à sociedade. Stillman II (2003, p. 37) aponta para três fases distintas da evolução da gestão pública norte-americana: (1) a primeira, coincidente com a Constituição de 1787; (2) a segunda, que vai de 1883 a 1940, em que se construiu, de fato e de direito, um Estado administrativo e (3) a terceira e última, ainda em andamento, no século 21, com as ideias de reforma do serviço público.

\subsubsection{A governança no setor público}

A adoção de práticas de governança corporativa em sociedades ou instituições contribui para atenuar os conflitos existentes entre aquele que administra os interesses de terceiros e os respectivos titulares desses interesses. É neste ponto que as práticas de governança pública apresentam-se como ferramenta útil, capaz de aproximar o cidadão do Estado, democratizando sua participação nas questões que lhe afetam. O Banco Mundial aponta que (1992, p. 9) sistemas ruins de governança pública causam problemas comuns aos países, tais como (1) falta de clareza na separação entre o público e o privado, com tendência à alocação de recursos públicos em favor de interesses privados; (2) excessivas regras, regulações, requisitos de licenciamentos e outros obstáculos ao desenvolvimento dos mercados, encorajando a intermediação privada nos interesses públicos, (3) além de má alocação de recursos e estabelecimento de prioridades inconsistentes com o desenvolvimento. 
Procurar-se-á demonstrar que a moldura normativa já existente forma um sistema coerente de governança pública, criando ao gestor o dever de transparência, prestação de contas e eficiência, restando comprovar se de fato tal estrutura tem sido suficiente e se tem sido efetivamente observada e aplicada.

Considerando o protagonismo do cidadão, como destinatário e participante da ação estatal, conforme o desenho institucional implantado pela Constituição Federal, a aplicação integral dos instrumentos de governança no setor público, em especial na gestão financeira do Estado, ganha relevância e deve orientar o comportamento dos gestores públicos e dos aplicadores do direito.

A CPA Austrália ${ }^{42}$ (2005, p. 4) explica que a adoção de mecanismos de governança no setor público aumenta a confiança da população no governo e nos serviços públicos prestados. Além disso, a boa governança propicia melhor produtividade, eficiência e eficácia da gestão pública, bem como aumenta a consciência, tanto da sociedade como dos gestores públicos, do papel do governo na busca permanente pelo atendimento ao interesse público e aos cidadãos.

Utilizando o exemplo da gestão de empresas privadas, a boa governança corporativa proporciona aos proprietários (acionistas ou cotistas) a gestão estratégica de sua empresa e a efetiva monitoração da direção executiva. Os mecanismos de governança corporativa na gestão privada contam, geralmente, com órgãos de execução e monitoramento que asseguram o controle da propriedade sobre a gestão. São eles: (1) a Diretoria executiva, (2) o Conselho de Administração, (3) o Conselho Fiscal e (4) a Auditoria Independente. Neste passo, é possível vislumbrar semelhanças entre as estruturas que sustentam a governança corporativa em uma empresa privada e as instituições presentes nos regimes democráticos de direito, onde os cidadãos escolhem, por meio do voto, os (1) governantes (chefes dos Poderes Executivos da União, Estados e Municípios), os (2) representantes nos parlamentos (Senadores, Deputados Federais, Estaduais e Vereadores), contando com a fiscalização dos (3) Tribunais de Contas (da União, dos Estados e dos Municípios, nos casos do Rio de Janeiro e São Paulo) e do (4) Ministério Público (da União e dos Estados).

Rosalvo Streit e Luis Klering (2004, p. 7), ao compilarem várias conceituações e definições do que é a governança pública, concluem que, apesar da

\footnotetext{
${ }^{42}$ Certified Public Accountants é uma entidade certificadora de profissionais da área de contabilidade e finanças.
} 
amplitude e variações do tema, algumas ideias centrais são recorrentes entre os mais diversos autores. Indicam, portanto, que o conceito faz referência (1) à existência de estruturas, mecanismos e regulamentações para o exercício da administração pública; (2) a uma nova prática de gestão, onde a ênfase se dá nos aspectos da participação, transparência, integridade e accountability; (3) a uma nova forma ou estrutura de administração pública, com maior flexibilidade, estrutura em rede, interdependência e regulação e (4) à definição clara de objetivos conjuntos e de responsabilidades entre os diversos atores. Assim sendo, a governança pública, segundo os autores (2004, p. 7), pode ser entendida como:

[...] o governo visando objetivos coletivos de uma sociedade, com o enfoque na coordenação autônoma, interdependente e responsável de diferentes instituições, redes e atores sociais, utilizando estruturas, mecanismos e regulações justas, coerentes, consistentes e aceita pela sociedade.

Para o Banco Mundial (World Bank, 1992, p.1), a governança no setor público pode ser definida como the manner in which power is exercised in the management of a country's economic and social resources for development ${ }^{43}$, sendo que, na opinião da instituição, a eficiência ou ineficiência dos sistemas de governança de um país ajudam a definir o seu desenvolvimento econômico.

Em trabalho apresentado pela Organização das Nações Unidas (2002, p.53-54), afirma-se que a governança "trata da interação entre o setor público e a sociedade, e de como esta se organiza para a tomada de decisão coletiva, de modo a que sejam providos mecanismos transparentes para que tais decisões se materializem”.

Paulo Henrique Ramos Medeiros e Tomás de Aquino Guimarães (2005, p.453) relacionam o conceito de governança à capacidade do governo de implementar suas políticas, além de se referir aos mecanismos legais e gerenciais para reforçar as instituições da sociedade civil e para tornar os governos mais abertos, responsáveis, transparentes e democráticos.

Já Bresser Pereira (2001, p. 12) define a governança como "um processo dinâmico pelo qual se dá o desenvolvimento político, onde a sociedade civil, o Estado e o governo organizam e gerem a vida pública”. Ainda segundo Bresser Pereira (1998, p.33),

\footnotetext{
${ }^{43}$ Governança é definida como "a maneira pela qual o poder é exercido na administração dos recursos sociais e econômicos de um país para o seu desenvolvimento" (tradução nossa).
} 
"governança é a capacidade financeira e administrativa, em sentido amplo, de um governo implementar políticas".

De todo modo, a nova concepção da administração pública e o papel relevante reservado ao cidadão determinam que os instrumentos de governança permeiem as ações do Poder Público. Nesse sentido, Eli Diniz (1996, p. 13) entende que a governança "Refere-se ao conjunto de mecanismos e procedimentos para lidar com a dimensão participativa e plural da sociedade, o que implica expandir e aperfeiçoar os meios de interlocução e de administração do jogo de interesses".

Fazendo-se distinção entre a multiplicidade de conceitos de governança, Gambhir Bhatta (2003, p. 5-6) explica que enquanto a governança trata da aquisição e distribuição de poder na sociedade, a governança corporativa denota a maneira em que as corporações são governadas e administradas, destacando que os princípios de governança corporativa, normalmente associados à gestão privada, são totalmente aplicáveis no setor público $^{44}$.

Leonardo Bento (2003, p. 85), ao tratar da governança pública, entende que esta "diz respeito aos pré-requisitos institucionais para a otimização do desempenho administrativo, isto é, o conjunto dos instrumentos técnicos de gestão que assegure a eficiência e a democratização das políticas públicas". Para Bento (2003, p. 86), "uma governança eficiente aumenta a legitimidade da política estatal e, portanto, a governabilidade do país, assim como é aumentada por esta". Ainda segundo o autor (2003, p. 87) a questão da governança "Implica, outrossim, normas que favoreçam a redução dos custos de transação, a produtividade, a flexibilidade, a descentralização, a participação, o mix ótimo entre o público e o privado, e a responsabilização dos governos e administradores por suas ações”.

A International Federation of Accountants (IFAC), por meio de seu comitê para o setor público (Public Sector Committee - PSC), elaborou abrangente estudo (IFAC, 2001) acerca dos aspectos que envolvem a governança no setor público, traçando recomendações para o estabelecimento de mecanismos institucionais de transparência, prestação de contas e participação. Gilmar Mello (2006, p. 39-40), comentando as

\footnotetext{
${ }^{44}$ Outra conceituação é dada por Lynn Jr., Heinrich e Hill (LYNN JR., Laurence E.; HEINRICH, Carolyn J.; HILL, Carolyn J. Studying governance and public management: challenges and prospects. Journal of Public Administration Research and Theory, v. 10. n. 2, p. 239, 2000) que entendem que a governança compreende estruturas e processos orientados à atividade administrativa que criam restrições e controles e que conferem ou permitem autonomia e discrição por parte dos atores administrativos para alcance de seus propósitos.
} 
recomendações propostas pelo $\mathrm{IFAC}^{45}$, destaca que o setor público deve perseguir os seguintes princípios de gestão: 1) transparência, à medida que os atos de gestão devem necessariamente alcançar o interesse público; 2) integridade, uma vez que ao administrador público compete agir sempre com honestidade na gestão da coisa pública e 3) responsabilidade na prestação de contas, também denominada accountability, que nada mais é do que a obrigação de informar a sociedade sobre sua gestão, para que esta possa realizar a avaliação de desempenho, efetivar os necessários controles, quando for o caso, e responsabilizar os agentes pelos seus atos.

Outra definição é dada por Hans Timmers (2000, p. 9), que chama a governança corporativa no setor público de governança governamental. Ao defini-la, enfatiza os mecanismos de proteção ao inter-relacionamento entre a administração, o controle e a supervisão. Também relaciona a governança à eficiência e eficácia na ação governamental e, por fim, inclui no conceito a transparência e a prestação de contas, inclusive com a evidenciação dos benefícios de cada política pública para a sociedade ${ }^{46}$. Hans Timmers (2000, p. 9) deixa claro que os sistemas de governança pública têm como um de seus escopos dar proteção para que o Estado possa alcançar os seus objetivos. Esta proteção se dá por meio de um ciclo estruturado do Estado, em que funcionam paralelamente o planejamento, o controle, o monitoramento e os processos de prestação de contas.

Baseado na definição de Timmers (2000, p. 10), a estrutura de governança governamental deve possuir alguns elementos essenciais, atuando conjuntamente sob o comando das instituições do Estado: (1) o primeiro elemento do ciclo de governança governamental, denominado "management", diz respeito à estrutura organizacional e às ações executivas para a consecução dos objetivos governamentais e implementação das políticas públicas; (2) o controle e a supervisão devem compor sistemas capazes de garantir que as ações sigam o curso correto, seja em relação à consecução dos objetivos, seja em relação ao cumprimento dos princípios da administração ou mesmo em relação à conformidade com o interesse público e, por fím, (3) a responsabilidade na prestação de contas (accountability), onde o Poder Público deve

\footnotetext{
${ }^{45}$ INTERNATIONAL FEDERATION OF ACCOUNTANTS - IFAC. Governance in the public sector: a governing body perspective. New York: 2001. p. 12. Disponível em: <http://www.ifac.org/Members/DownLoads/Study_13_Governance.pdf>. Acesso em: 24 mar. 2009.

${ }^{46}[. .$.$] government governance is defined as safeguarding the interrelationship between management, control$ and supervision by government organizations and by organizations set up by government authorities, aimed at realizing policy objectives efficiently and effectively, as well as communicating openly thereon and providing an account thereof for the benefit of the stakeholders.
} 
prover informações detalhadas e amplas, com absoluta transparência, das ações, resultados, custos e responsabilidades na implementação das políticas.

Pat Barret (2002, p. 6) destaca os princípios aos quais as entidades do setor público devem aderir para efetivamente aplicar os elementos de governança corporativa e alcançar as melhores práticas: liderança, integridade e compromisso (relativos a qualidades pessoais), responsabilidade em prestar contas, integração e transparência.

A utilização do termo governança, como se vê, varia dependendo da perspectiva da qual se analisa o tema. Dada a multiplicidade de modelos de governança existentes, bem como de diferentes abordagens para o assunto, não é possível estabelecer um padrão único de governança no setor público ${ }^{47}$.

Mark Bevir, Rod Rhodes e Patrick Weller (2003, p. 24) também chamam a atenção para a amplitude e elasticidade do conceito de governança, salientando que o termo tem um significado diferente na França ou na Inglaterra, por exemplo, tendo em vista as diferenças entre as estruturas governamentais, culturais, linguísticas e a própria forma com que o termo é empregado em cada caso.

Tratando-se a governança, como se percebe, de um conceito amplo, é preciso delimitar o enfoque que se pretende dar ao tema, tendo em vista que este trabalho tem como objeto a moldura normativa que rege a atividade financeira do Estado, encarada sob a perspectiva da governança. Embora reconhecendo que a doutrina aponta para a existência de múltiplas conceituações e diferenciações entre a governança no setor público e a governança corporativa aplicada nas companhias mercantis, para o escopo deste trabalho é importante destacar alguns mecanismos e princípios comuns da boa governança no setor público, aqueles capazes de garantir ao cidadão a gestão republicana dos recursos públicos.

\footnotetext{
${ }^{47}$ Cf. MARQUES, Maria da Conceição da Costa. Corporate governance in the public sector in Portugal: principles, elements and conceptual framework. Califórnia: An International Meeting of the American Accounting Association, 2005. p. 13) e INTERNATIONAL FEDERATION OF ACCOUNTANTS IFAC. Governance in the public sector: a governing body perspective. New York: 2001, cit., p. 2). Segundo Santiso (Good governance and aid effectiveness: the world bank and conditionality. The Georgetown Public Policy Review, v. 7, n. 1, p.5, 2001), apesar do uso crescente do conceito de boa governança, os seus contornos permanecem incertos, pois ainda não há uma inequívoca e operacional definição do conceito. Esta multiplicidade de definições gerou uma confusão quanto aos limites do conceito.
} 
Com base no estudo 13, do PSC/IFAC (2001, p. 5), destacam-se alguns conceitos e recomendações importantes para a delimitação do tema deste trabalho, reforçando que, apesar de haver estruturas normativas diferentes entre um país e outro ou entre entes federados, é possível identificar alguns princípios comuns de boa governança que podem ser aplicados a qualquer órgão do setor público:

Transparência é requisito para garantir a confiança da sociedade nos processos de tomada de decisão e nas ações do gestor público, o qual deve propiciar informações claras, acuradas e amplas.

A integridade, caracterizada pela honestidade e probidade do gestor público, deve permear a gestão dos recursos públicos.

Por fim, a accountability, vista como o dever que tem o gestor público de prestar contas e, consequentemente, ser responsabilizado pelos seus atos.

Ainda segundo o estudo do IFAC (2001, p. 12-13), é possível estabelecer, a partir dos princípios acima, quatro dimensões que concretizam a boa governança no setor público: (1) padrões de comportamento; (2) estruturas e processos organizacionais; (3) controle e (4) relatórios externos.

São os padrões de comportamento que definem como será o exercício da liderança e a difusão dos valores e da cultura na organização. Neste aspecto, o estudo do IFAC (2001, p. 14) recomenda que as entidades públicas adotem códigos de conduta, onde estejam formalmente explicitados os comportamentos éticos esperados para o gestor público, colaborando para garantir a honestidade e probidade na gestão da coisa pública.

As estruturas e processos organizacionais precisam propiciar a salvaguarda dos recursos públicos, que devem ser aplicados dentro de critérios de eficiência e eficácia. Além disso, a moldura normativa que regula a atuação da gestão pública deve estar apta a garantir a transparência de todas as atividades da administração, assim como precisa definir com clareza os papéis e as responsabilidades de cada agente público (IFAC, 2001, p. 14).

Ao controle da administração compete seguir padrões contábeis e estabelecer medidas de performance para a administração. Além disso, os mecanismos de controle, interno e externo, devem estar aptos para a gestão de riscos (IFAC, 2001, p. 14). 
Por relatórios externos, o IFAC (2001, p. 14) denomina toda a produção de informações colocadas à disposição da sociedade e dos órgãos de controle externo, permitindo ampla transparência.

A CPA Austrália (2005, p. 4) define os princípios da integridade, transparência e accountability como fundamentais para a boa governança pública.

John Graham, Bruce Amos e Tim Plumptre (2003, p. 3-4) citam os cinco princípios da boa governança definidos pelo Programa de Desenvolvimento das Nações Unidas: (1) participação do cidadão na tomada de decisão e nas ações governamentais; (2) visão estratégica e perspectiva de longo prazo voltada para o desenvolvimento humano; (3) processos voltados para a eficiência e eficácia; (4) accountability e transparência e (5) equidade e cumprimento das leis e regras estabelecidas.

O Banco Mundial (1992, p. 12), em relatório que relaciona a governança pública ao desenvolvimento, também aponta a transparência e a accountability como dimensões da governança, o que é corroborado por Pat Barret (2001, p. 6), que também entende que as organizações do setor público devem ser transparentes e responsáveis por suas atividades. Os cidadãos, como destinatários da ação estatal, são titulares do direito de serem informados acerca da aplicação dos recursos públicos e dos resultados que estão sendo alcançados com estes recursos.

A despeito de todos os enfoques dados à governança no setor público, bem como da aplicação dos instrumentos de governança corporativa, hoje disseminada nas grandes empresas de capital aberto, é preciso identificar os aspectos mais relevantes para a boa gestão financeira do Estado, considerando que a aplicação dos recursos públicos deve visar aos interesses da sociedade, titular da res publica. Nesse sentido, os instrumentos democráticos estabelecidos pela Constituição Federal de 1988 e a legislação pertinente à gestão financeira da Administração Pública formam uma moldura institucional capaz, ao menos em tese, de garantir a boa gestão dos recursos públicos. Cabe, então, identificar os mecanismos institucionais, normativos e administrativos, capazes de garantir à sociedade a proteção de seus interesses na gestão dos recursos públicos, permitindo o monitoramento da gestão e a efetiva participação dos cidadãos.

Fernando Abrúcio (2004, p. 75) apresenta o conceito de accountability democrática, que se configura na "construção de mecanismos institucionais por meio dos 
quais os governantes são constrangidos a responder ininterruptamente por seus atos ou omissões perante os governados". Abrúcio (2004, p. 75) aponta para a estreita relação entre a accountability democrática e as reformas na gestão pública, enfatizando que o enfoque do tema tem sido a análise de "como o aperfeiçoamento das instituições estatais pode contemplar, ao mesmo tempo, a melhoria do desempenho dos programas governamentais e sua maior transparência e responsabilização do poder público frente à sociedade".

A gestão financeira do Estado deve conciliar eficiência econômica e o exercício da democracia (Abrúcio, 2004, p. 79). De fato, vários estudos apontam para a relevância dos instrumentos de governança para o desenvolvimento social e econômico ${ }^{48}$. Para isso, é preciso que exista uma estrutura normativa adequada para o exercício dos institutos democráticos, bem como é indispensável que os mesmos sejam aplicados com efetividade.

Considerando-se a atividade financeira do Estado, objeto do Direito Financeiro, alguns princípios da boa governança no setor público exercem papel fundamental para a efetivação dos preceitos republicanos e democráticos.

Fernando Abrúcio (2004, p. 81) aponta três princípios orientadores da democracia:

Primeiro: o governo deve emanar da vontade popular. Segundo: os governantes devem prestar contas ao povo, responsabilizando-se perante ele. E terceiro: o Estado deve ser regido por regras que delimitem seu campo de atuação em prol da defesa de direitos básicos do cidadão, tanto individuais quanto coletivos.

Ainda segundo o raciocínio de Fernando Abrúcio (2004, p. 81), a esses três vetores democráticos correspondem formas de accountability, ou seja,

[...] a responsabilização política ininterrupta do Poder Público em relação à sociedade. A primeira delas é o processo eleitoral, garantidor da

\footnotetext{
${ }^{48} \mathrm{Cf}$. World Bank (WORLD Bank. Governance and development. Washington-DC: World Bank Publications, 1992. p. 9-12); (BARRETT, Pat. Corporate governance in the public sector context. Canberra, 2001. p. 6-11. Disponível em: $<$ http://www.anao.gov.au/uploads/documents/Corporate_Governance_in_the_Public_Sector_Context.pdf >. Acesso em: 29 jun. 2009); HUTHER, Jeff; SHAH, Anwar. Applying a simple measure of good governance to the debate on fiscal decentralization. Social Science Research Network, Nov. 1999. Disponível em: $<$ http://papers.ssrn.com/sol3/papers.cfm?abstract_id=620584>. Acesso em: 20 jul. 2009. Conforme Grindle (2004, p.533-534), considerando que a boa governança pode reduzir a corrupção, melhorar a prestação de contas, propiciar melhor gestão dos recursos públicos, de fato tais mecanismos podem ser essenciais para a redução da pobreza.
} 
soberania popular. A segunda é o controle institucional durante os mandatos, que fornece os mecanismos de fiscalização contínua dos representantes eleitos e da alta burocracia com responsabilidade decisória. Por fim, a terceira forma de accountability democrática relaciona-se à criação de regras estatais intertemporais, pelas quais o poder governamental é limitado em seu escopo de atuação [...].

Os princípios de governança pública que serão abordados neste trabalho são aqueles que estão relacionados com a gestão financeira do Estado e que exercem papel relevante como instrumento de garantia dos direitos republicanos, os quais serão analisados mais adiante.

A cada um dos fundamentos de governança pública a seguir indicados, aplicados à gestão financeira do Estado, corresponde um princípio constitucional ou preceito legal que, se corretamente interpretado e aplicado, garante à sociedade efetividade ao princípio republicano.

O dever de prestar contas à sociedade e a responsabilização do agente público por seus atos (accountability) é um dos pilares mais importantes da governança pública, especialmente em matéria de finanças públicas, onde o bom uso dos recursos públicos é essencial para os interesses da sociedade.

A prestação de contas, por sua vez, não pode prescindir de ampla transparência dos atos da gestão. O cidadão deve ter acesso a informações claras, precisas e completas dos objetivos da gestão, do planejamento orçamentário, da execução orçamentária e financeira, da situação fiscal de cada ente público, incluindo os riscos fiscais e o endividamento público, dos custos dos serviços públicos prestados e dos resultados alcançados. É preciso também que o administrador público coloque à disposição da sociedade medidas de performance da gestão e do alcance dos objetivos propostos. $\mathrm{O}$ controle de performance deve envolver, portanto, os aspectos relacionados à eficiência e à eficácia na alocação dos recursos públicos. Para tal, a gestão financeira deve estar suportada pelo uso de ferramentas de planejamento estratégico, gestão de riscos, indicadores de desempenho e monitoramento permanente. A responsabilidade na gestão dos recursos públicos deve ser aprimorada por meio de ação planejada e transparente que possibilite prevenir riscos e corrigir desvios capazes de afetar o equilíbrio das contas públicas. 
Como decorrência dos pressupostos acima, outro pilar da governança em matéria de finanças públicas é a atividade de controle, interno e externo. O cidadão é titular do direito de acompanhar a aplicação dos recursos que a sociedade, por meio do recolhimento dos tributos, colocou à disposição do Estado. Mais do que isto, é preciso que a atividade de controle previna ou corrija eventuais distorções.

O controle externo, realizado pelos órgãos competentes, tem como função a fiscalização técnica e independente da gestão pública. Além do controle recíproco realizado entre os Poderes, os Tribunais de Contas e o Ministério Público têm papel relevante na fiscalização financeira dos órgãos públicos.

O controle interno, por sua vez, deve ser capaz não apenas de identificar eventuais desvios, mas principalmente de acompanhar o desempenho da gestão pública, a fim de aprimorar permanentemente a performance, além de prestar contas à sociedade.

A interpretação do ordenamento vigente pós Constituição de 1988 permite acrescentar a estes pilares a efetiva participação do cidadão na gestão e o dever de cumprimento das regras e princípios por parte do gestor público.

O constituinte de 1988 engendrou um sistema político e institucional que prevê a participação efetiva do cidadão na vida pública, não apenas na atividade política, com a escolha de seus representantes e nas possibilidades de participação indireta ${ }^{49}$, mas também no cotidiano das ações governamentais, na prestação dos serviços públicos e na tomada de decisões relevantes que afetem os interesses da coletividade. Por outro lado, todo o sistema democrático pressupõe que o agente público ou político aja com integridade e honestidade. Na governança corporativa aplicada às empresas privadas, este dever é designado em inglês como "compliance", que significa agir em conformidade com as regras, princípios e valores estabelecidos. Obviamente que ao gestor público compete, além de agir de acordo com as normas, regras e valores estabelecidos, observar a ética e atuar sempre em prol do interesse público. É a partir dessas premissas que o administrador deverá ser responsabilizado pelos seus atos.

O feixe de fundamentos e preceitos acima formam o que se pode chamar de um sistema de governança capaz de garantir ao cidadão e à sociedade a boa gestão dos recursos públicos. Tais elementos estão inter-relacionados e têm, como já dito, fundamento constitucional e legal, devendo ser aplicado pelos diversos órgãos e instituições do Estado.

\footnotetext{
${ }^{49}$ Plebiscito, Referendum e Iniciativa Popular, entre outras.
} 
Assim, nos capítulos seguintes abordar-se-á como este sistema de governança, que será adiante chamado de governança republicana apenas para não gerar confusão com os outros conceitos de governança pública, governança corporativa, governança democrática e outros já abordados, está institucionalizado em nosso ordenamento jurídico e como ele opera entre os diversos órgãos do Estado.

Com enfoque exclusivo na gestão financeira do Estado, serão abordados a seguir, jurídica e administrativamente, a accountability, a transparência e os mecanismos de controle da administração, sempre sob os pressupostos da eficiência do uso dos recursos, do monitoramento do desempenho e dos resultados alcançados, da participação efetiva do cidadão e da conduta de ética e de respeito do administrador pelas normas, regras e valores estabelecidos (compliance).

\subsubsection{A Governança republicana}

O Estado democrático é, na verdade, uma associação obrigatória de seus cidadãos, onde estes elegem seus dirigentes e representantes, sob a disciplina da Constituição Federal e, mediante contribuições pecuniárias, necessárias à prestação dos serviços públicos e investimentos, financiam a ação estatal.

A famosa frase de Abraham Lincoln, "governo do povo, pelo povo e para o povo", sintetiza bem o conceito republicano de democracia nos moldes contemporâneos, presente na Constituição Federal de 1998, em que o Parágrafo único, do artigo $1^{\circ}$, preconiza que "Todo o poder emana do povo, que o exerce por meio de representantes eleitos ou diretamente [...]", nos termos estabelecidos pela própria Carta.

O cidadão é o titular da coisa pública e todos os agentes públicos ${ }^{50}$, eleitos ou não, são representantes diretos ou indiretos dos interesses coletivos desses cidadãos. Muito embora se possa dizer que a República é o oposto da Monarquia ${ }^{51}$,

\footnotetext{
${ }^{50}$ Agente público, nos termos do art. $2^{\text {o }}$ da Lei n. 8.429/92, é todo aquele que exerce, ainda que transitoriamente ou sem remuneração, por eleição, nomeação, designação, contratação ou qualquer outra forma de investidura ou vínculo, mandato, cargo, emprego ou função nas instituições mencionadas no art. $1^{\circ}$ daquele diploma legal. Neste caso, a administração direta, indireta ou fundacional de qualquer dos Poderes da União, dos Estados, do Distrito Federal, dos Municípios, de Território, de empresa incorporada ao patrimônio público ou de entidade para cuja criação ou custeio o erário haja concorrido ou concorra com mais de cinquenta por cento do patrimônio ou da receita anual, além de entidade que receba subvenção, benefício ou incentivo, fiscal ou creditício, de órgão público bem como daquelas para cuja criação ou custeio o erário haja concorrido ou concorra com menos de cinquenta por cento do patrimônio ou da receita anual.

${ }^{51}$ OLIVEIRA, Cristina Godoy Bernardo de; BARBOSA, Suzana Mesquita; BAGNOLI, Vicente. História do direito. Rio de Janeiro: Elsevier, 2009. p. 145.
} 
modernamente é possível considerar que a característica essencial dos regimes republicanos é a possibilidade de participação do povo no governo, sendo a sociedade a destinatária do interesse público, incluindo o patrimônio público.

Nos regimes democráticos de direito, a efetiva participação do cidadão na vida pública ocorre não apenas com o direito à escolha de seus representantes e governantes, mas também por meio da atuação direta em órgãos de representação, audiências públicas, acesso a canais de comunicação, bem como pelo monitoramento das atividades dos gestores, além de outros instrumentos de participação popular ${ }^{52}$.

A par do protagonismo do cidadão frente ao Estado, José Afonso da Silva (2008, p. 106) entende que

\begin{abstract}
A Democracia que o Estado Democrático de Direito realiza há de ser um processo de convivência social numa sociedade livre, justa e solidária (art. $3^{\circ}, \mathrm{II}$ ), em que o poder emana do povo, que deve ser exercido em proveito do povo, diretamente ou por representantes eleitos (art. $1^{\circ}$, parágrafo único); participativa porque envolve a participação crescente do povo no processo decisório e na formação dos atos de governo [...].
\end{abstract}

Lygia Bandeira de Mello Parente (2006, p. 207) compreende que

[...] essa participação cidadã se transforma em ampliação das possibilidades de acesso dos setores populares aos atos de gestão, segundo uma perspectiva de desenvolvimento da sociedade civil e de fortalecimento dos mecanismos democráticos, e contribui para garantir a execução eficiente dos programas de compensação social que surgiram no contexto das políticas de ajuste estrutural.

Marcos Augusto Perez (2004, p. 35) defende que a moldura institucional concebida pela Carta Constitucional de 1988 estabelece "um verdadeiro princípio jurídico, o princípio da participação, que passa a ser encarado como pré-requisito da perfeita

\footnotetext{
${ }^{52}$ PARENTE, Lygia Bandeira de Mello. Participação social como instrumento para a construção da democracia: a intervenção social na administração pública brasileira. In SOUZA JUNIOR, José Geraldo de (Org.). Sociedade democrática: direito público e controle externo. Brasília: Tribunal de Contas da União, 2006. p. 209 enumera alguns mecanismos de participação previstos na Constituição brasileira tais como: plebiscito, referendo, iniciativa legislativa popular. Outros exemplos de instrumentos de participação social existentes na Constituição são: a ação popular, o habeas corpus, o habeas data, o mandado de segurança e o mandado de injunção. Cita-se ainda a formação de conselhos e a instituição de ouvidorias no âmbito da Administração Pública, bem como a existência e a atuação dos diversos grupos de pressão, que estão garantidos na forma de direitos de reunião, de associação, de petição, de sindicalização. Além disso, há a
} 
concretização da ordem democrática" e que está diretamente vinculado ao modelo republicano brasileiro ${ }^{53}$.

Seguindo ensinamento de Roque Carrazza (1999, p. 43), para se buscar a exata definição do nosso modelo republicano é preciso interpretar a Constituição Federal brasileira, não havendo nenhuma relevância, para o objeto deste trabalho, o estudo comparativo das características específicas de outros países ou das origens da República. Segundo ele (Carrazza, 1999, p. 43), é a Constituição Federal "que traça o perfil e as peculiaridades da República brasileira”.

Ainda para não afastar a discussão do enfoque proposto, não se discutirá o conceito de República sob a perspectiva da forma de governo, mas apenas os valores relativos ao papel do Estado na defesa dos interesses dos cidadãos como titulares da res publica ou o Estado como protetor supremo dos interesses materiais e morais dos cidadãos, fundado nos preceitos da igualdade, da representatividade por mandato transitório, sempre em nome do povo e de seus interesses, sob pena de responsabilização pelos atos que afrontem o interesse público (Carrazza, 1999, p. 44-56). Partindo desses pressupostos, o princípio republicano, do qual decorre o direito de que a coisa pública seja sempre gerida em prol da sociedade, tem fundamental importância quando se trata da gestão financeira do Estado. Ao tecer suas considerações especificamente sobre o controle das finanças públicas e os direitos fundamentais, Ricardo Lobo Torres (2000, p. 499) ensina que

Os direitos fundamentais têm uma relação profunda e essencial com as finanças públicas. Dependem, para a sua integridade e defesa, da saúde e do equilíbrio da atividade financeira do Estado, ao mesmo tempo em que lhe fornecem o fundamento da legalidade e da legitimidade. Os direitos

possibilidade de participação em conselhos de gestão de serviços públicos e também por meio de novas formas de interação hoje disponíveis na internet (blog, twitter, facebook, etc.).

${ }^{53}$ Cf. BREDER, Jane Carvalho. Controle social: um modelo em construção: contribuições do Tribunal de Contas da União. In: SOUSA Jr., José Geraldo (Org.). Sociedade democrática, direito público e controle externo. Brasília: Tribunal de Contas da União, 2006. p. 191: “A Constituição Federal, deste modo, trouxe normas que conferem ao cidadão e à sociedade civil organizada o direito à informação e de petição (artigos $5^{\circ}$, XXXIII/XXXIV; 31, §3º e 162); à participação nos colegiados de órgãos públicos relacionados aos seus interesses profissionais ou previdenciários; na administração pública direta e indireta, como usuários; na fixação da política agrícola; na proteção do patrimônio cultural; na defesa e preservação do meio ambiente; e na assistência à saúde e do adolescente (artigos $10 ; 37, \S 3^{\circ} ; 187 ; 216, \S 1^{\circ} ; 225 ;$ e $227, \S 1^{\circ}$ ); à participação direta nos processos político-decisórios e legislativos (artigos. 14, I-III; 29, XII-XIII; e 61, $\S 2^{\circ}$ ); à participação comunitária na gestão democrática e descentralizada da seguridade social, da saúde, assistência social e ensino público (arts. 194, parágrafo único, VII; 198, III; 204, II; e 206, VI); à provocação do controle judicial dos atos da Administração, mediante ação popular (art. $5^{\circ}$, LXXIII), Lei n $^{\circ}$ 4.717/1995), ação civil pública (art. 129, III/Lei no 7.347/1985) e outros meios (art. 5º incisos LXVIII/art. 647 do CPP; LXIX; LXX/Lei n 1.533/1951; LXXI; LXXII, e art. 103, IX); e à provocação do controle externo em face de irregularidades $\left(\right.$ art. $74, \S 2^{\circ}$ ). 
fundamentais se relacionam com os diversos aspectos das finanças públicas.

A relação entre as finanças públicas e os direitos fundamentais está vinculada à própria existência do Estado. De fato, o cidadão recolhe tributos e espera receber do Estado a proteção de seus direitos fundamentais. Nesse sentido, Ricardo Lobo Torres defende que

[...] o tributo, categoria básica da receita do Estado de Direito, é o preço da liberdade, preço que o cidadão paga para ver garantidos os seus direitos e para se distanciar do Leviatã, deixando de lhe entregar serviços pessoais. Por outro lado, tributo nasce no espaço aberto pela autolimitação da liberdade, por incidir sobre a riqueza produzida pela liberdade de iniciativa (art. $5^{\circ}$, XIII, da Constituição Federal) ou sobre o próprio direito de propriedade, observada a sua função social (art. $5^{\circ}$, XXII XXI, CF). Toda a temática das isenções e dos incentivos fiscais afeta os direitos fundamentais, tendo em vista que o benefício concedido a alguns é sempre suportado pelos outros cidadãos.

Mais do que a importância da atividade financeira do Estado como instrumento garantidor dos direitos fundamentais do cidadão, é preciso ressaltar a relevância das finanças públicas na perspectiva republicana. Ricardo Lobo Torres (2000, p. 499) ressalta que

[...] também o patrimônio público ganha dimensão constitucional, uma vez que qualquer cidadão é parte legítima para propor ação popular que vise a anular ato que lhe seja lesivo (art. $5^{\circ}$, LXXIII, CF); os bens patrimoniais do Estado, mesmo os disponíveis, estão afetados pela 'evidência pública' e constituem 'direito ou interesse legítimo a favor de terceiros', o que torna difícil distingui-los dos bens comuns e coletivos.

Se de um lado a garantia à propriedade privada é um direito fundamental erigido na Constituição Federal ${ }^{54}$, nenhum sentido haveria em deixar de fora do rol de direitos fundamentais, ainda que não expresso, a garantia de que os recursos públicos angariados pela tributação da sociedade sejam bem geridos pelo administrador público. Assim como na atividade de arrecadação dos tributos, o Estado submete-se a uma série de limitações ao poder de tributar decorrentes do princípio republicano (Carrazza, 1999, p. 62-65), verdadeiro direito fundamental denominado de estatuto do contribuinte, a atividade financeira estatal também está balizada por princípios e normas tendentes à preservação de 
direito fundamental do cidadão de que os recursos públicos sejam geridos em favor dos interesses da sociedade.

Na acepção de Regis de Oliveira (2008, p. 65), a "atividade financeira é, pois, a arrecadação de receitas, sua gestão e a realização do gasto, a fim de atender às necessidades públicas". As finanças públicas, assim, podem ser vistas como o suporte material à garantia dos direitos fundamentais e também como o estrato financeiro do patrimônio público, cujo titular é o cidadão, decorrência direta do princípio republicano.

Ricardo Lobo Torres (2000, p. 500) reforça a ideia afirmando que "as finanças públicas, em todas as suas dimensões - tributária, patrimonial, monetária, orçamentária, promocional, etc. - encontram-se em permanente e íntimo contato com os direitos fundamentais". Porém, se as finanças públicas estão diretamente vinculadas aos direitos fundamentais, bem como se as limitações ao poder de tributar do Estado configuram-se em direito fundamental decorrente do princípio republicano, a gestão desses recursos públicos deve estar, pois, protegida também como um direito fundamental.

Por fim, Ricardo Lobo Torres (2000, p. 501) complementa, afirmando que

[...] também os gastos públicos estão inteiramente voltados para os direitos humanos. O serviço público, financiado com o dinheiro do Estado, neles encontra o seu fundamento e a sua finalidade. As prestações positivas do Estado para a segurança dos direitos fundamentais, que compõem o status positivus libertatis, bem como a garantia do mínimo existencial, representada pelas prestações no campo da educação, saúde e assistência social e até a proteção dos direitos difusos, como acontece com o meio ambiente e os bens culturais, demandam o aporte de recursos públicos substanciais.

Essa concepção se aproxima do que Bresser Pereira (2009, p. 127) chama de direito republicano, que nada mais é do que "o direito que todos os cidadãos têm ao uso público da res publica - do patrimônio público - inclusive o fluxo de recursos envolvidos nas receitas do Estado e das organizações públicas não estatais”. Para o autor (1997, p. 7), os direitos de cidadania são resultado da luta pela afirmação e, historicamente, os direitos assegurados pelo Estado em favor do cidadão são: (1) os direitos civis e políticos, que defendem o cidadão "contra um Estado autoritário e oligárquico"; (2) os direitos sociais, 
"contra os ricos ou poderosos" e (3) os direitos republicanos, que protegem o cidadão "contra os aproveitadores ou privatizadores da res publica".

Na evolução dos direitos fundamentais conquistados pelos cidadãos, Bresser Pereira (2009, p. 127-130) aponta inicialmente os direitos à liberdade e à propriedade, chamados direitos civis; após isso, o direito de votar e de ser eleito, considerados direitos políticos, o direito ao trabalho, à educação, à saúde e a uma renda mínima; em uma terceira fase, classificados como direitos sociais, e mais recentemente o direito a que a res publica continue a serviço de todos em vez de ser controlada por interesses privados, o que ele denomina de direitos republicanos.

É a partir da década de 1970 que foram cunhadas expressões como "privatização do Estado"55 e rent-seeking" (Bresser Pereira, 2009, p. 129). Para Bresser Pereira (2009, 129-130), "Reformar o Estado, proteger o patrimônio público, tornar os funcionários governamentais mais eficientes e responsáveis passaram a ser problemas centrais em ciência política”.

A questão central dos direitos republicanos está na concepção do que é o interesse público ou da sociedade, tendo em vista que há sempre um feixe de interesses coexistindo muitas vezes de forma contraditória. Bresser (2009, p. 134-135) entende que o sentido de interesse público de uma sociedade é formado a partir de um consenso, com base nos valores cívicos que permeiam aquela sociedade. Para Bresser (2009, p. 138), o interesse público existe como um conceito positivo: é o interesse sancionado pelo Parlamento e pelos tribunais na forma de direito positivo.

De fato, a identificação do que é o interesse público no caso concreto não é empreitada simples, pois que os múltiplos interesses envolvidos em cada ato ou atividade da administração pública podem estar contrapostos. Entretanto, é possível estabelecer para cada situação real, tratando-se da gestão financeira do Estado, interesses comuns baseados nos valores e princípios previstos na Constituição Federal e nas normas inferiores.

Embora a concepção de direitos republicanos proposta por Bresser Pereira (2009, p. 130-131) envolva o patrimônio ambiental, o patrimônio cultural e o

\footnotetext{
${ }^{55}$ Segundo Bresser, esta expressão foi utilizada pela primeira vez pelo cientista político Luciano Martins em 1978.

${ }^{56}$ Bresser cita esta expressão, utilizada pela economista Anne Krueger em 1974, que designa a busca de rendimentos extramercados mediante o controle do governo.
} 
patrimônio econômico público, o escopo deste trabalho limita-se a este último, especificamente no que se refere aos recursos financeiros.

Diferentemente dos direitos civis e sociais, cuja proteção é normalmente dirigida contra o Estado, nos direitos republicanos a defesa do cidadão se volta também contra o particular que se apropria indevidamente do patrimônio. Nesse sentido, uma das formas mais comuns de apropriação indevida, embora não a única, é a corrupção.

Segundo Vilmar Agapito Teixeira (2006, p. 345),

[...] a corrupção é um modo de influir nas decisões públicas que fere no íntimo o próprio sistema democrático. Este tipo privilegiado de influência, reservado àqueles que possuem meios de exercê-la, conduz ao desgaste do mais importante elemento do sistema, sua legitimidade.

Régis de Oliveira (2008, p. 243), em profundo estudo sobre a corrupção, anota que esta prática lesa os direitos fundamentais e sua "consequência evidente é a agressão aos direitos humanos, bem como compromete o crescimento econômico" (Oliveira, 2008, p. 246).

Porém, o direito republicano, em verdade, é mais do que proteção à sociedade contra os aproveitadores ou privatizadores da res publica, mas é o direito que tem o cidadão de que a coisa pública seja sempre gerida em favor da coletividade, o que pressupõe também a gestão eficiente e eficaz do patrimônio público, a efetiva participação do cidadão nessa gestão e a responsabilização dos agentes públicos pelos seus atos. Para a efetivação desses pressupostos é imperativo que o gestor público aja com transparência e que existam sistemas de monitoramento e controle da gestão, não só para os aspectos relacionados ao desempenho, mas também para a garantia da boa condução dos interesses públicos.

Em termos de gestão financeira, os instrumentos normativos e administrativos existentes formam um sistema de proteção social que, funcionando perfeitamente, garantem à sociedade que os direitos republicanos sejam preservados.

Embora os conceitos de governança corporativa tenham sido profundamente analisados na gestão de empreendimentos privados, não resta dúvida de que a organização da administração pública nos regimes democráticos está fundamentada 
em pilares que propiciam a transparência, a prestação de contas, a responsabilização, a equidade, o cumprimento das normas e a busca pela eficiência administrativa. Trata-se, em verdade, de uma decorrência do princípio republicano estabelecido na Constituição Federal, que coloca o cidadão como o titular da coisa pública (res publica) ${ }^{57}$.

Os dispositivos normativos e instrumentos gerenciais garantidores dos direitos republicanos em matéria de finanças públicas serão designados neste trabalho, como dito, para efeitos didáticos, como governança republicana.

A gestão do setor público tem seus alicerces fixados nos princípios previstos no artigo 37 da Constituição Federal. Tais princípios, conjugados com diplomas legais específicos, estabelecem uma moldura normativa que regerá o comportamento do administrador público, garantindo que o interesse público seja protegido e constantemente monitorado.

As práticas de governança fundamentam-se em princípios estruturais que devem permear integralmente as ações da organização, quais sejam: transparência, responsabilidade pelos resultados e pela prestação de contas (accountability), além de equidade e ética (cumprimento das normas e moralidade). Também é possível identificar perfeitamente analogias com os próprios princípios que regem a administração pública brasileira, previstos na Constituição Federal de 1988.

Assim, é conveniente reforçar que, em matéria de gestão financeira do Estado, a Carta Constitucional estruturou, sob a égide de um regime democrático de direito, um sistema de governança, aqui denominado de governança republicana, que parametriza a ação do gestor público, direcionando-o para (1) a gestão eficiente dos recursos, (2) a prestação de contas e responsabilização pelos seus atos, (3) a transparência, (4) a equidade, (5) a ética e (6) a efetiva participação do cidadão.

No âmbito das finanças públicas, a governança republicana, portanto, pode ser definida como um complexo de normas e instrumentos gerenciais sistematizados que garantem ao cidadão que a gestão financeira do Estado seja realizada de acordo com o interesse público, pautada sempre pela transparência, pelo permanente monitoramento e

\footnotetext{
${ }^{57}$ O Professor Régis de Oliveira (OLIVEIRA, Régis Fernandes de. Curso de direito financeiro. 2. ed. São Paulo: Ed. Revista dos Tribunais, 2008. p. 478), ao tratar da Responsabilidade Fiscal, afirma que a "transparência é reflexo e consequência dos princípios republicano e democrático".
} 
pela efetiva participação social. O esquema abaixo ilustra bem o funcionamento dos instrumentos de governança republicana em matéria de finanças públicas:

\section{GOVERNANÇA REPUBLICANA EM MATÉRIA DE FINANÇAS PÚBLICAS}

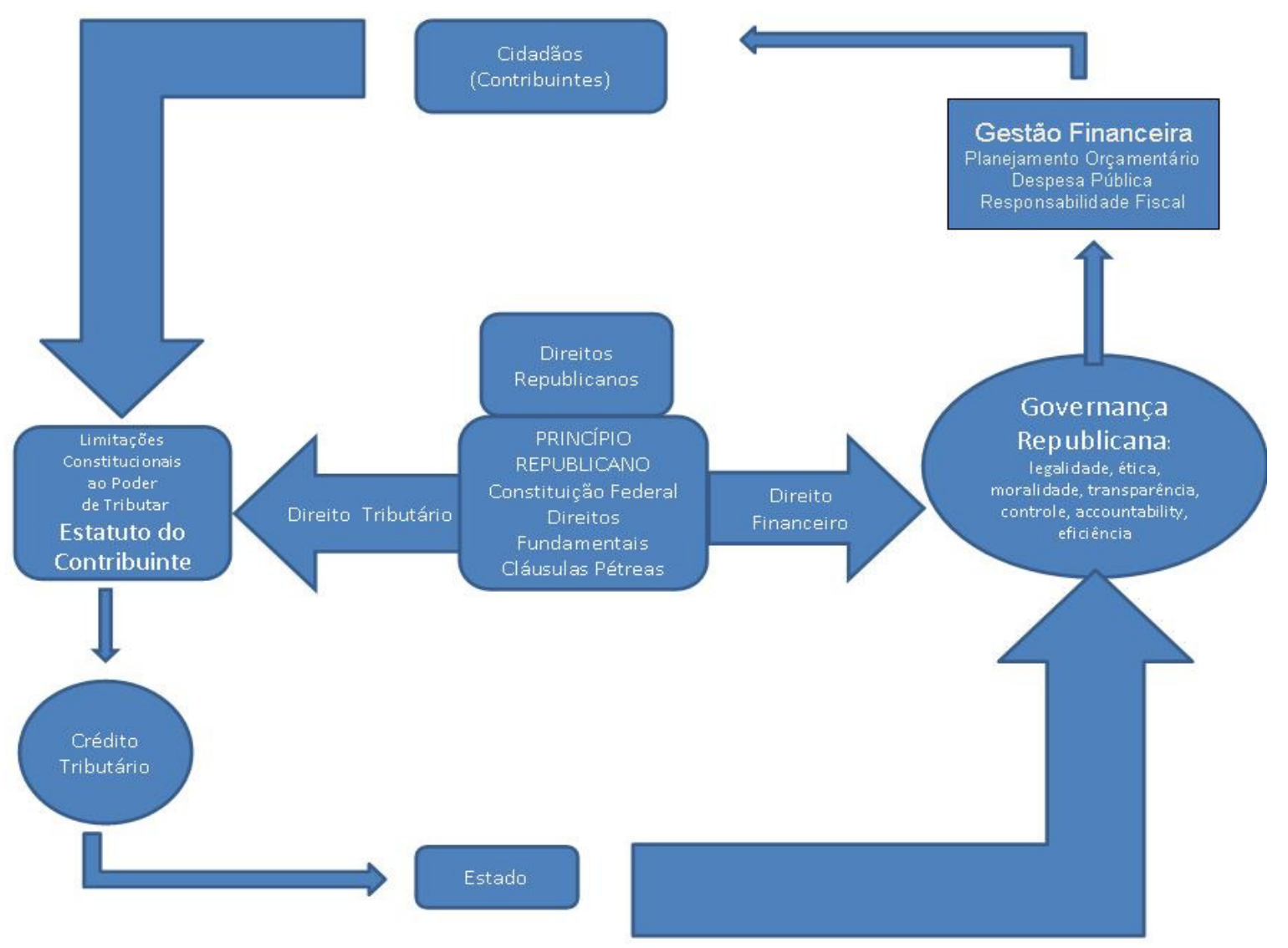

Figura 1 - A Governança Republicana e as Finanças Públicas

O diagrama acima mostra, de forma simplificada, o funcionamento das estruturas de governança republicana na gestão financeira do Estado. De um lado, a tributação da sociedade, limitada constitucionalmente pelo que alguns autores denominam de estatuto do contribuinte ${ }^{58}$, que nada mais é do que um complexo de direitos

\footnotetext{
${ }^{58}$ Cf. Humberto Ávila, (ÁVILA, Humberto. Estatuto do contribuinte: conteúdo e alcance. Revista Diálogo Jurídico, ano 1, v. 1, n. 3, p. 1, jun. 2001), para quem "a expressão 'Estatuto do Contribuinte' denota um conjunto de normas que regula a relação entre o contribuinte e o ente tributante", e Roque Carrazza (CARRAZZA, Roque Antonio. Curso de direito constitucional tributário. 12. ed. São Paulo: Malheiros Ed., 1999).
} 
fundamentais que garantem ao cidadão o respeito aos princípios republicano e democrático insculpidos na Constituição Federal ${ }^{59}$. Uma vez arrecadados tais recursos, o Estado os administra visando ao bem-estar da sociedade, inclusive para a garantia dos demais direitos fundamentais do cidadão e para a prestação de serviços públicos e investimentos. A boa gestão dos recursos públicos constitui-se também em verdadeiro direito fundamental decorrente do princípio republicano, qual seja, o direito republicano de que a gestão financeira do Estado seja permanentemente voltada aos interesses da sociedade, envolvendo eficiência, transparência, monitoramento, controle, prestação de contas, responsabilização dos agentes públicos pelos seus atos e participação social.

Para a garantia efetiva desses direitos republicanos, o sistema democrático brasileiro estabeleceu, por meio de normas constitucionais e infraconstitucionais, um sistema de governança republicana, cujo pleno funcionamento permite a boa gestão financeira do Estado. E para que este sistema de governança republicana funcione de maneira adequada, é preciso que os princípios constitucionais norteadores da administração pública, bem como as normas de direito financeiro, sejam interpretados de acordo com as premissas anteriormente apresentadas, quais sejam, o cidadão é o titular da res publica, cabendo aos agentes públicos gerir as finanças públicas de acordo com os interesses da sociedade, submetendo-se integralmente a um regime de governança republicana, cujos aplicadores do direito deverão considerar como vetor de interpretação das normas de Direito Financeiro.

\footnotetext{
${ }^{59}$ Nesse sentido, Lygia Bandeira de Mello Parente (PARENTE, Lygia Bandeira de Mello. op. cit., p. 209) rememora as lições de Bonavides (2003), que "a exequibilidade da Constituição vai depender de quanto o seu texto corresponde ao equilíbrio real de forças políticas e sociais em determinado momento. Não basta uma Constituição bem escrita para que seja cumprida e obedecida. Há possibilidade de se travar, pelas vias do direito e com base na Constituição, uma batalha própria, capaz de melhorar as condições sociais, por meio da garantia do exercício de direitos individuais e de cidadania a todos, da forma mais abrangente possível. Nesse sentido, uma ordem jurídica bem estabelecida pode ser instrumento significativo de melhoria social". A autora (op. cit., p. 209) reforça que "a Constituição Federal, ao atribuir ao Brasil a forma de Estado Democrático de Direito, condiciona que as decisões estatais sejam fundadas na vontade popular e subordinadas aos direitos e garantias fundamentais, em especial àqueles que dizem respeito à liberdade, igualdade e justiça". Para ela (op. cit., p. 209), "o conceito de Estado Democrático de Direito aplicado à Administração Pública brasileira garante a todos os indivíduos o exercício amplo do poder político. Essa interpretação também encontra respaldo em normativos da Organização dos Estados Americanos, que reconhece a participação social como um dos componentes da democracia, onde o Estado passa a ter o encargo de administrar a aplicação dos princípios constitucionais de uma democracia participativa e a sua conformação jurídica com os princípios da soberania popular”.
} 


\section{PRINCÍPIOS CONSTITUCIONAIS E GOVERNANÇA REPUBLICANA}

\subsection{Interpretação e aplicação dos princípios}

No modelo de ordenamento jurídico adotado no Brasil, de inspiração kelseniana, a interpretação das normas infraconstitucionais deve se dar em perfeita consonância com os preceitos contidos na Constituição, por ela consistir na norma fundamental e de maior hierarquia jurídico-normativa.

A Constituição Federal Brasileira de 1988 estabelece como princípios aplicáveis à Administração Pública, direta e indireta, de qualquer esfera da Federação, a legalidade, a impessoalidade, a moralidade, a publicidade e a eficiência, no caput de seu artigo 37. Esses são, portanto, os princípios-chaves que devem ser observados pela Administração Pública em geral.

Decorre disto a necessidade de que a aplicação das normas relativas ao Direito Administrativo ocorra em conformidade com tais princípios e, ainda, com os subprincípios deles decorrentes. Da mesma forma, normas relativas ao Direito Financeiro devem ser interpretadas e aplicadas tendo como norte os princípios constitucionais dirigidos à Administração Pública.

Neste capítulo, portanto, pretende-se analisar alguns princípios constitucionais que regem as boas práticas da Administração Pública e, assim, demonstrar que a governança republicana possui fundamento constitucional, devendo servir de vetor para interpretação das normas de Direito Financeiro.

José Afonso da Silva (2004, p. 119) afirma que a palavra princípio é equívoca. Em sua obra, o autor tenta distinguir o sentido da palavra princípio, quando utilizada de diferentes formas em três conceitos correlatos, quais sejam, (i) normas 
constitucionais de princípio, (ii) normas constitucionais de princípios gerais, e (iii) princípios gerais do direito constitucional ${ }^{60}$.

Luís Roberto Barroso (2009, p. 317), por sua vez, ao abordar a normatividade dos princípios, não apresenta um conceito fechado de princípios, mas enumera como características dos princípios as seguintes: “(i) expressam valores ou fins a serem alcançados; (ii) indicam estados ideais e comportam realização por meio de variadas condutas; (iii) podem entrar em rota de colisão com outros princípios ou encontrar resistência por parte da realidade fática, hipóteses em que serão aplicados mediante ponderação.” Além disso, o autor (2009, p. 316-317) assevera ainda que os princípios, com sua flexibilidade, dão margem à realização da justiça do caso concreto e que, "no ambiente pós-positivista de reaproximação entre o Direito e a Ética, os princípios constitucionais se transformam na porta de entrada dos valores dentro do universo jurídico”.

Raquel Melo Urbano de Carvalho (2008, p. 30), ao abordar a evolução da noção de princípios na ciência jurídica, traz a definição de princípios consagrada por Robert Alexy ${ }^{61}$ :

Robert Alexy aduz que os valores se diferenciam dos princípios exatamente em razão da normatividade jurídica dos últimos, definidos como "mandamentos de otimização, que estão caracterizados pelo fato de que podem ser cumpridos em diferentes graus e que a medida devida do seu cumprimento não só depende das possibilidades reais, mas também das jurídicas".

\footnotetext{
${ }^{60}$ Segundo José Afonso da Silva (SILVA, José Afonso da. Aplicabilidade das normas constitucionais. 6. ed. São Paulo: Malheiros Ed., 2004. p. 119-120), "Quando falamos em normas definidoras de princípios institutivos, a palavra "princípio" se apresenta na acepção própria de começo ou início, isto é, são normas que contêm o início ou o esquema de determinado órgão, entidade ou instituição, deixando a efetiva criação, estruturação ou formação para a lei complementar ou ordinária (...). Diferentes são as normas constitucionais de princípios ferais, ou normas-princípios. Estas são, segundo Crisafulli, "as normas fundamentais de que derivam logicamente (e que, portanto, já se manifestam implicitamente) as normas particulares regulando imediatamente relações e situações específicas da vida social". Mais adequado seria chamá-las de normas fundamentais (a Constituição de 1988 as chama de princípios fundamentais), de que as normas particulares são mero desdobramento analítico. (...) profundamente diversos são os princípios gerais do direito constitucional. "A ciência do direito constitucional [diz Pinto Ferreira] induz da realidade histórico-social os lineamentos básicos, os grandes princípios constitucionais, que servem de base à estruturação do Estado (...)"

${ }^{61}$ ALEXY, Robert. Teoria de los derechos fundamentales. Madrid: Centro de Estudios Constitucionales, 1997, p. 86 e 138, apud CARVALHO, Raquel Melo Urbano de. Curso de direito administrativo. Salvador: Juspodivm, 2008. p. 30.

Humberto Ávila (ÁVILA, Humberto. Teoria dos princípios: da definição à aplicação dos princípios jurídicos. São Paulo: Malheiros Ed., 2009. p. 37) também cita a contribuição de Alexy para a definição de princípios: "Alexy, partindo das considerações de Dworkin, precisou ainda mais o conceito de princípios. Para ele os princípios jurídicos consistem apenas em uma espécie de normas jurídicas por meio da qual são estabelecidos deveres de otimização aplicáveis em vários graus, segundo as possibilidades normativas e fáticas" (Apud, ALEXY, Robert. Zum Begriff des Rechtsprinzips, Argumentation und Hermeneutik in der Jurisprudenz, Rechstheorie, Separata 1/65).”
} 
Consoante já mencionado, a aplicação das normas jurídicas deve ser realizada em consonância com os princípios contidos na Constituição Federal. Essa necessidade é reconhecida amplamente pela jurisprudência, que admite, inclusive, a mitigação da aplicação de determinados preceitos normativos como forma de concretização do conteúdo dos princípios constitucionais ${ }^{62}$.

Assim, em função da preponderância da observância dos princípios constitucionais sobre o conteúdo das normas jurídicas, serão abordados, adiante, os conceitos específicos dos princípios constitucionais informadores da governança republicana no Direito Financeiro, de modo a possibilitar a interpretação e a aplicação das respectivas normas em consonância com o estabelecido na Carta Constitucional.

Com a finalidade de diferenciar regras de princípios, Humberto Ávila (2009, p. 76) leciona que

\begin{abstract}
As regras podem ser dissociadas dos princípios quanto ao modo como contribuem para decisão. Os princípios consistem em normas primariamente complementares e preliminarmente parciais, na medida em que, sobre abrangerem apenas parte dos aspectos relevantes para uma tomada de decisão, não têm a pretensão de gerar uma solução específica, mas de contribuir, ao lado de outras razões, para a tomada de decisão [...] Já as regras consistem em normas preliminarmente decisivas e abarcantes na medida em que, a despeito da pretensão de abranger todos os aspectos relevantes para a tomada de decisão, têm a aspiração de gerar uma solução específica para o conflito entre razões.
\end{abstract}

No que concerne à interpretação de princípios jurídicos, em geral, Humberto Ávila apresenta considerações de suma importância. Inicialmente, o autor (2009, p. 31-32) preceitua que “a interpretação não se caracteriza como um ato de

\footnotetext{
${ }^{62}$ STJ: PROCESSO CIVIL E ADMINISTRATIVO. RECURSO ESPECIAL. SUS. CUSTEIO DE TRATAMENTO MÉDICO. MOLÉSTIA GRAVE. DIREITO À VIDA E À SAÚDE. BLOQUEIO DE VALORES EM CONTAS PÚBLICAS. POSSIBILIDADE. ART. 461 DO CPC.

1. A Constituição Federal excepcionou da exigência do precatório os créditos de natureza alimentícia, entre os quais incluem-se aqueles relacionados com a garantia da manutenção da vida, como os decorrentes do fornecimento de medicamentos pelo Estado.

2. É lícito ao magistrado determinar o bloqueio de valores em contas públicas para garantir o custeio de tratamento médico indispensável, como meio de concretizar o princípio da dignidade da pessoa humana e do direito à vida e à saúde. Nessas situações, a norma contida no art. $461, \$ 5^{\circ}$, do Código de Processo Civil deve ser interpretada de acordo com princípios e normas constitucionais, sendo permitido, inclusive, a mitigação da impenhorabilidade dos bens públicos.

3. Recurso especial não provido.

(REsp n ${ }^{\circ} 824.164$ - RS, Segunda Turma, Relator Ministro João Otávio de Noronha, DJ 04.05.2006, v.u.).
} 
descrição de um significado previamente dado, mas como um ato de decisão que constitui a significação e os sentidos de um texto”.

Carlos Maximiliano (2008, p. 1) introduz as lições contidas em sua obra clássica afirmando que "a hermenêutica jurídica tem por objeto o estudo e a sistematização dos processos aplicáveis para determinar o sentido e o alcance das expressões do Direito”.

Ao distinguir a hermenêutica das atividades de interpretação e de aplicação do Direito, o autor (2008, p. 1) assevera que "a Hermenêutica é a teoria científica da arte de interpretar”. No que tange às demais atividades, aduz o autor (2008, p. $5-7)^{63}$ :

A aplicação do Direito consiste no enquadrar um caso concreto em a norma jurídica adequada. Submete às prescrições da lei uma relação da vida real; procura e indica o dispositivo adaptável a um fato determinado. Por outras palavras: tem por objeto descobrir o modo e os meios de amparar juridicamente um interesse humano (...) Interpretar é explicar, esclarecer, dar o significado de vocábulo, atitude ou gesto, reproduzir por outras palavras um pensamento exteriorizado; mostrar o sentido verdadeiro de uma expressão; extrair, de frase, sentença ou norma, tudo o que na mesma se contém.

Neste sentido, cumpre, preliminarmente, trazer à colação o conceito de interpretação contido na obra de Gilmar Ferreira Mendes, Inocêncio Mártires Coelho e Paulo Gustavo Gonet Branco (2008, p. 56), in verbis:

[...] a interpretação de qualquer norma jurídica é uma atividade intelectual que tem por finalidade precípua - estabelecendo o seu sentido - tornar possível a aplicação de enunciados normativos, necessariamente abstratos e gerais, a situações da vida, naturalmente particulares e concretas. ${ }^{64}$

\footnotetext{
${ }^{63}$ Importante ressaltar que a obra de Maximiliano, a despeito de sua importância para a doutrina, foi escrita antes da vigência da Constituição Federal de 1988, em um tempo em que o Direito Público ainda não tinha a evolução atual.

${ }^{64}$ Luís Roberto Barroso (BARROSO, Luís Roberto. Curso de direito constitucional contemporâneo. 1. ed. 3. tir. São Paulo: Saraiva, 2009. p. 269-270) afirma que a interpretação jurídica "consiste na atividade de revelar ou atribuir sentido a textos ou outros elementos normativos (como princípios implícitos, costumes, precedentes), notadamente para o fim de solucionar problemas. Trata-se de uma atividade intelectual informada por métodos, técnicas e parâmetros que procuram dar-lhe legitimidade, racionalidade e controlabilidade. A aplicação de uma norma jurídica é o momento final do processo interpretativo, sua incidência sobre os fatos relevantes. Na aplicação se dá a conversão da disposição abstrata em uma regra concreta, com a pretensão de conformar a realidade ao Direito, o ser ao dever ser. É nesse momento que a norma jurídica se transforma em norma de decisão".
} 
A interpretação das normas constitucionais, nelas incluídas as normas que instituem princípios, por sua posição de supremacia sobre todos os demais ramos do Direito, considerando que a Constituição expressa a vontade superior do povo, rege-se de forma diferente da interpretação das normas infraconstitucionais, que têm por norte os preceitos mais elevados, contidos na Carta Magna.

Não obstante, diversos métodos interpretativos podem ser utilizados com vistas a aplicação das normas jurídicas, entre os quais podemos citar os mais comuns, a seguir: (i) interpretação gramatical, literal ou semântica; (ii) interpretação histórica; (iii) interpretação sistemática; e (iv) interpretação teleológica.

Independentemente do método a ser utilizado pelo intérprete, há uma série de princípios informadores da interpretação constitucional que auxiliam na aplicação das normas infraconstitucionais de forma consentânea com os preceitos contidos na Carta Magna.

Com efeito, devem as normas infraconstitucionais ser interpretadas e aplicadas com base nos princípios da supremacia da Constituição, da presunção de constitucionalidade das leis e atos normativos, da interpretação conforme a Constituição, da unidade da Constituição, da razoabilidade e da máxima efetividade das normas constitucionais.

Com fundamento nesses princípios, que regem a interpretação normativa no ordenamento jurídico nacional, serão analisados os princípios constitucionais que regem a atividade da Administração Pública - e os sub-princípios deles decorrentes - e que, especificamente, no que concerne ao Direito Financeiro, indicam a necessidade de o Poder Público adotar a governança republicana como mecanismo essencial para a gestão pública.

Humberto Ávila (2009, p. 97), que debruçou-se sobre a questão da eficácia dos princípios com profundidade, afirma que ${ }^{65}$

\footnotetext{
${ }^{65}$ Ainda a respeito da aplicação dos princípios, no entendimento de Humberto Ávila (ÁVILA, Humberto. Teoria dos princípios: da definição à aplicação dos princípios jurídicos, cit., 98-99), "em primeiro lugar, relativamente às normas mais amplas (sobre-princípios), os princípios exercem uma função definitória, na medida em que delimitam, com maior especificação, o comando mais amplo estabelecido pelo sobreprincípio axiologicamente superior". (...) "em segundo lugar, e agora em relação às normas de abrangência mais restrita, os (sobre) princípios exercem uma função interpretativa, na medida em que servem para interpretar normas concluídas a partir de textos normativos expressos, restringindo ou ampliando seus sentidos". E conclui o autor que "essas considerações qualificam os princípios como decisões valorativas objetivas com função explicativa (objektive Wertentsheidung mit erläuternder Funktion), nas hipóteses em que orientam a interpretação de normas constitucionais ou legais".
} 
Os princípios, por serem normas imediatamente finalísticas, estabelecem um estado ideal de coisas a ser buscado, que diz respeito a outras normas do mesmo sistema, notadamente das regras. Sendo assim, os princípios são normas importantes para a compreensão do sentido das regras.

Nesse sentido, a lógica do sistema de governança republicana é a aplicação de princípios e normas voltadas à gestão financeira do Estado de modo a garantir que os interesses da sociedade prevaleçam. Eventualmente, se alguma norma ou ação afronte o princípio republicano, a efetiva aplicação dos princípios deve exercer sua função bloqueadora, garantindo a proteção à res publica ${ }^{66}$.

Com isso, o autor (2009, p. 99-100) considera essencial destacar "a eficácia externa que os princípios têm", explicando que, "como eles estabelecem indiretamente um valor pelo estabelecimento de um estado ideal de coisas a ser buscado, indiretamente eles fornecem um parâmetro para o exame da pertinência e da valoração”. Nesse diapasão, o autor exemplifica que "o princípio da segurança jurídica estabelece um ideal de previsibilidade da atuação estatal, mensurabilidade das obrigações, continuidade e estabilidade das relações entre o Poder Público e o cidadão" 67.

No caso da gestão financeira do Estado, onde as questões envolvidas são normalmente de ordem econômica, a questão do atendimento ao interesse público está atrelada à lógica das decisões mais eficientes e menos custosas (Anderson, 1979, p. 719) ${ }^{68}$.

Observa-se, assim, que, até mesmo sob a ótica da teoria política, as decisões da Administração Pública não devem decorrer pura e simplesmente de um juízo valorativo, econômico e político. Com efeito, para que atendam devidamente ao interesse público, as decisões do Poder Público devem ser balizadas por princípios que, por sua

\footnotetext{
${ }^{66} \mathrm{Na}$ lição de Humberto Ávila (ÁVILA, Humberto. Teoria dos princípios: da definição à aplicação dos princípios jurídicos, cit., p. 99), “os princípios exercem uma função bloqueadora, porquanto afastam elementos expressamente previstos que sejam incompatíveis com o estado ideal de coisas a ser promovido. Por exemplo, se há uma regra prevendo a abertura de prazo, mas o prazo previsto é insuficiente para garantir efetiva protetividade aos direitos do cidadão, um prazo adequado deverá ser garantido em razão da eficácia bloqueadora do princípio do devido processo legal".

${ }^{67}$ Humberto Ávila (Id. Ibid., p. 101) afirma, ainda, que, dado que os princípios descrevem um estado de coisas a ser buscado, não definem previamente os meios passíveis de serem adotados para produzir efeitos que contribuirão para promover o estado buscado.

68“"In many models of policy evaluation, efficiency is regarded as tantamount to rationality. The problem of policy is 'solved' when it can be demonstrated that one alternative yields an optimum level of benefits over costs. As we have noted, rationality is often defined in an instrumental sense, as 'goal-directed behavior' in policy theory. Yet, some conceptions of policy rationality carry the matter even further. They argue that the efficient solution to a policy problem is also the solution that is necessarily in the public interest. In fact, latent in the logic of much of contemporary political economy, whether founded on neoclassical or utilitarian premises, is the notion that to solve for the problem of efficiency is simultaneously to solve for the problems of authority and of justice".
} 
própria essência, não são objetivamente delimitáveis, de modo que possam ser constantemente atualizados ao grau de maturidade institucional do ordenamento jurídico vigente e da sociedade contemporânea, bem como às necessidades sociais, o que poderá ser extraído dos princípios que serão melhor explorados a seguir.

\subsection{Princípio da legalidade e governança republicana}

A doutrina nacional afirma que o surgimento do princípio da legalidade foi o resultado de uma reação ao Absolutismo europeu. Nesse sentido, leciona Maria Sylvia Di Pietro (2009, p. 63) que o princípio da legalidade

[...] nasceu com o Estado de Direito e constitui uma das principais garantias de respeito aos direitos individuais. Isto porque a lei, ao mesmo tempo em que os define, estabelece também limites da atuação administrativa que tenha por objeto a restrição ao exercício de tais direitos em benefício da coletividade.

A Declaração dos Direitos do Homem e do Cidadão, de 1789, também faz menção à legalidade, ao tratar da liberdade dos cidadãos, em seu artigo $4^{\circ}$, asseverando que os limites à liberdade dos seres humanos somente podem ser estabelecidos por lei ${ }^{69}$.

No ordenamento jurídico nacional, o princípio da legalidade possui status constitucional. Seu fundamento último está assentado no artigo $5^{\circ}$, II, da Constituição Federal Brasileira, que estabelece como garantia fundamental dos cidadãos, protegida por cláusula pétrea e, portanto, imodificável, que "ninguém será obrigado a fazer ou deixar de fazer alguma coisa senão em virtude de lei”.

Na esfera do Direito Administrativo, por sua vez, a Constituição Federal de 1988 estabeleceu o princípio da legalidade como princípio constitucional aplicável aos atos da Administração Pública, no caput de seu artigo 37.

Ainda antes da promulgação da Constituição Federal de 1988, a lei da ação popular ( $n^{\circ} 4.717$, de 29.06.1965) já tratava como nulos os atos lesivos ao patrimônio das entidades mencionadas naquele diploma normativo em casos de ilegalidade de objeto,

\footnotetext{
${ }^{69}$ "La liberté consiste à pouvoir faire tout ce qui ne nuit pas à autrui : ainsi l'exercice des droits naturels de chaque homme n'a de bornes que celles qui assurent aux autres Membres de la Société, la jouissance de ces mêmes droits. Ces bornes ne peuvent être déterminées que par la Loi."
} 
assim considerado como aquele vício que ocorre quando o resultado do ato importa em violação da lei, de regulamento ou de outro ato normativo ${ }^{70}$.

Cumpre, ainda, mencionar a lição de Celso Antônio Bandeira de Mello (2009, p. 100), que a respeito do princípio da legalidade comenta que:

O princípio da legalidade contrapõe-se, portanto, e visceralmente, a quaisquer tendências de exacerbação personalista dos governantes. Opõese a todas as formas de poder autoritário, desde o absolutista, contra o qual irrompeu, até as manifestações caudilhescas ou messiânicas típicas dos países sub-desenvolvidos. O princípio da legalidade é o antídoto natural do poder monocrático ou oligárquico, pois tem como raiz a ideia de soberania popular, de exaltação da cidadania. Nesta última se consagra a radical subversão do anterior esquema de poder assentado na relação soberano-súdito (submisso).

Assevera também, Celso Antônio Bandeira de Mello (2009, p. 101), que "na conformidade da máxima oriunda do Direito inglês, que no Estado de Direito, quer-se o governo das leis, e não o dos homens; impera a rule of law, not of men”.

Consoante anteriormente afirmado, segundo o princípio geral da legalidade, previsto no artigo $5^{\circ}$, II, da Constituição Federal, ninguém é obrigado a fazer coisa alguma senão em virtude de determinação legal.

Contudo, segundo o princípio da legalidade estrita, aplicável à Administração Pública e previsto no artigo 37, caput, da Constituição Federal, somente é admitido que o Poder Público faça o que esteja expressamente previsto em lei.

Com efeito, a doutrina tradicional assenta que, no direito brasileiro, toda atuação administrativa é respaldada na lei e que mesmo a competência discricionária só existe quando autorizada por lei, referindo-se apenas a alguns elementos do ato administrativo relativos ao mérito do ato, diante da necessária avaliação da conveniência e da oportunidade para sua produção.

Neste sentido, cumpre citar o entendimento do Supremo Tribunal Federal:

A Administração Pública, em toda a sua atividade, está sujeita aos mandamentos da lei, deles não se podendo afastar, sob pena de invalidade do ato e responsabilidade de seu autor. Qualquer ação estatal

\footnotetext{
${ }^{70}$ Cf. MEIRELLES, Hely Lopes. Direito administrativo brasileiro. São Paulo: Malheiros Ed., 2009. p. 89.
} 
sem o correspondente amparo legal, ou que exceda ao âmbito demarcado pela lei, é injurídica e expõe-se à anulação, pois, a eficácia de toda atividade administrativa está condicionada ao atendimento da lei: na Administração Pública não há liberdade nem vontade pessoal, e só é permitido fazer o que a lei autoriza. (RE 195227/DF Rel. Min. Maurício Correa, DJU 06/12/1996 pg. 48727)

Raquel Melo Urbano de Carvalho (2008, p. 53) destaca que o princípio da legalidade poderia ser reinterpretado como princípio da juridicidade, uma vez que o administrador está vinculado ao Direito como um todo, incluindo-se, além da mera observância das leis formais e de sua regulamentação, os princípios jurídicos, as normas e valores constitucionais.

Hely Lopes Meirelles (2009, p. 89) também apregoa o alargamento da extensão do princípio da legalidade, salientando que

[...] a legalidade, como princípio de administração (CF, art. 37, caput), significa que o administrador público está, em toda a sua atividade funcional, sujeito aos mandamentos da lei e às exigências do bem comum, e deles não se pode afastar ou desviar, sob pena de praticar ato inválido e expor-se a responsabilidade disciplinar, civil e criminal, conforme o caso.

Após destacar que o princípio da legalidade é precisamente aquele que qualifica o Estado de Direito, com o qual nasceu o próprio Direito Administrativo, Celso Antônio Bandeira de Mello (2009, p. 100) aduz que "a Administração Pública só pode ser exercida na conformidade da lei e que, de conseguinte, a atividade administrativa é atividade sublegal, infralegal, consistente na expedição de comandos complementares à lei”.

É importante ressaltar, ainda, que o princípio da legalidade estrita no Direito Administrativo vem sofrendo modificações recentemente. Com efeito, o chamado pós-modernismo ocasionou uma mudança de paradigmas no Direito Administrativo, que passou a valorizar ainda mais os direitos do homem, admitindo-se uma espécie de retorno do humanismo em substituição ao rigor exagerado das formas.

Assim, passou-se a enfatizar os motivos e a finalidade dos atos administrativos em detrimento do formalismo exacerbado em sua produção. 
Destarte, a Administração Pública passou a estar submetida não apenas ao princípio da legalidade como também deve ser exigida legitimidade para a produção de atos administrativos. Nota-se, portanto, que, cada vez mais o princípio da legalidade, aplicável à Administração Pública, alcança maior importância e tem seu conteúdo mais alargado, consoante será demonstrado adiante.

Contrariando, de certa forma, essa tendência de alargamento do princípio da legalidade, Hely Lopes Meirelles (2009, p. 89) observa que "na Administração Pública não há liberdade nem vontade pessoal". Na esteira do entendimento do autor, pode-se dizer, portanto, que, enquanto a lei para o particular significa "pode fazer assim", para o administrador público significa "deve fazer assim". Aduz, ainda, Hely Lopes Meirelles (2009, p. 90) que, "enquanto na administração particular é lícito fazer tudo que a lei não proíbe, na Administração Pública só é permitido fazer o que a lei autoriza”.

Celso Antônio Bandeira de Mello (2009, p. 100), por sua vez, ensina que,

[...] para avaliar corretamente o princípio da legalidade e captar-lhe o sentido profundo cumpre atentar para o fato de que ele é a tradução jurídica de um propósito político: o de submeter os exercentes do poder em concreto - o administrativo - a um quadro normativo que embargue favoritismos, perseguições ou desmandos. Pretende-se através da norma geral, abstrata e por isso mesmo impessoal, a lei, editada, pois, pelo Poder Legislativo - que é o colégio representativo de todas as tendências (inclusive minoritárias) do corpo social -, garantir que a atuação do Executivo nada mais seja senão a concretização desta vontade geral.

Contudo, consoante mencionado, o conteúdo do princípio da legalidade administrativa, cada vez mais, tem se alargado, de modo que compreenda não apenas a legalidade estrita, mas a juridicidade, assim consideradas todas as normas e princípios jurídicos aplicáveis à Administração Pública, e também a legitimidade na produção dos atos administrativos, considerando os motivos, a finalidade e a eficiência em sua produção.

Absorve-se, da lição acima, que o princípio da legalidade tem conteúdo que deve pautar o gestor público e o aplicador do direito, tendo como beneficiário o cidadão e a sociedade, à medida que protege o administrado contra abusos, desmandos, favorecimentos e injustiças por parte do agente público. Por essa razão, o princípio da legalidade compõe o sistema de proteção à res publica, aqui denominado de governança republicana. 
O objetivo último do princípio da legalidade é restringir a atuação da Administração Pública ao quanto previsto na legislação vigente, o que, em última análise, consiste na consecução de ações que visem ao atendimento e à preservação do interesse público. Destarte, considerando que o interesse público é indisponível e, em regra, possui status de supremacia sobre os demais bens e interesses, a atuação da Administração Pública deve se dar em perfeita consonância com as normas estabelecidas no ordenamento jurídico pátrio, reduzindo a subjetividade inerente aos atos de gestão nas tomadas de decisões que ensejem a aplicação de recursos públicos, o estabelecimento de metas e prioridades e a adoção de políticas públicas que produzem efeitos - positivos ou não sobre toda a sociedade, ressaltando que os recursos públicos são limitados e as necessidades públicas são infinitas (Kramer, 1983, p. 1000).

Além disso, o fato de o princípio da legalidade figurar na Constituição Federal de 1988 como garantia individual e, portanto, cláusula pétrea, também indica o ideal protetivo deste princípio, que consiste em uma forma de assegurar segurança jurídica às relações sociais, considerando que os cidadãos têm a garantia de que o Administrador não irá atuar em desconformidade com a legislação e, caso o faça, seus atos poderão ser prontamente anulados. Utilizando expressão em inglês para designar de forma ampla o princípio da legalidade, poder-se-ia denominá-lo de compliance, que significa um comportamento pautado pelas normas e regras vigentes, pela ética e pela boa-fé. É, na verdade, o que se espera do gestor público em geral e, particularmente, daquele que gere os recursos públicos.

O princípio da legalidade é aplicável a toda a Administração Pública, em todas as esferas federativas e a todos os servidores públicos, dos mais baixos aos mais altos cargos ocupados junto ao Poder Público, sob pena de responsabilização civil, administrativa e até mesmo penal em casos de descumprimento.

Consoante anteriormente mencionado, o princípio da legalidade constitui garantia individual constitucionalmente assegurada a todos os cidadãos. Por essa razão, o referido princípio destina-se, como mencionado, a todos os gestores públicos, seja da Administração Pública direta ou indireta, que mantenham ou não vínculos efetivos com o Poder Público. Neste sentido, o conceito de agente público já citado anteriormente pode ser adotado para indicar aqueles que se submetem ao princípio da legalidade. 
Este princípio também se destina, lato sensu, a todos aqueles que, de alguma forma, utilizem ou administrem recursos públicos, dada a necessidade de prestação de contas da aplicação regular de tais recursos estabelecida no artigo 70, parágrafo único, da Constituição Federal e o fato de que qualquer aplicação de recursos públicos em dissonância com a legislação implica em responsabilização dos agentes que assim agirem.

Porém, pode-se dizer, ainda, que o princípio da legalidade aplicável à Administração Pública também é dirigido aos administrados, em sentido lato, uma vez que eles são os beneficiários últimos do referido princípio e, assim, a observância do princípio da legalidade tem também por finalidade assegurar aos cidadãos que a Administração Pública não se portará de forma contrária ao estabelecido na legislação, conforme anteriormente asseverado.

Em reforço, o conteúdo do princípio da legalidade aplicável à Administração Pública não se restringe pura e simplesmente à letra da lei, mas também aos princípios administrativos, constitucionais e às regras de conduta comumente exigíveis do administrador público.

Hely Lopes Meirelles (2009, p. 89) reforça a ideia de que a obediência do gestor público ao princípio da legalidade é mais do que o estrito cumprimento da lei, mas sim a absoluta submissão aos princípios e à ética:

Cumprir simplesmente a lei na frieza de seu texto não é o mesmo que
atendê-la na sua letra e no seu espírito. A administração, por isso, deve
ser orientada pelos princípios do Direito e da Moral, para que ao legal
se ajunte o honesto e o conveniente aos interesses sociais. Desses
princípios é que o Direito Público extraiu e sistematizou a teoria da
moralidade administrativa (grifo nosso).

Há, portanto, uma clara intersecção entre o princípio da moralidade administrativa e o princípio da legalidade aplicável à Administração Pública, ensejando a legitimação dos atos praticados pela Administração Pública em favor dos cidadãos.

Isso não é uma exclusividade do direito brasileiro. Com efeito, a doutrina internacional também trata dessa questão há décadas. Presley Melton (1939, p. 836) apregoava que o administrador público era responsável por manter os mecanismos internos da Administração operando corretamente e também por conduzir os negócios do governo com o máximo de eficiência e o mínimo de atritos. 
O citado autor (1939, p. 839) também aduz que, em função do regime jurídico da Administração Pública, é responsabilidade de oficiais, a quem podemos chamar autoridades, aferir se o trabalho é realizado, constantemente, com o máximo de eficiência.

Melton (1939, p. 840) já criticava a visão de administradores que consideravam os órgãos administrativos e a atividade por eles desempenhada como um fim em si mesmo, louvando a necessidade de que os administradores tenham sempre em mente os objetivos e finalidades institucionais do órgão como condição para o desempenho eficiente das atividades no seio da Administração Pública ${ }^{71}$.

Gordon Clapp (1937, p. 111), por sua vez, ressalta que as características da boa administração pública são "virile morale, creative thinking, a free flow of workable ideas, honest effort, and loyalty to high ideals of public service”. Acrescenta ainda, o autor, que tais características apenas encontram-se presentes onde os seus destinatários, isto é, os administradores públicos, desde que comprometidos, deem cumprimento às normas estabelecidas pelos seus superiores.

Não há dúvida de que o cumprimento da lei e dos dispositivos constitucionais representa o consenso mínimo do interesse público, uma vez que cabe aos representantes eleitos a aprovação dessas normas. Não obstante, Steven Cohen e William Eimicke (1995, p. 98) dissertam sobre a competência e o poder político do governo de fazer as leis e fazê-las ser cumpridas em prol do interesse público:

The discussion of public ethics and where they come from goes to the very heart of the American philosophy of government, beginning with the writings of John Locke. By most accounts, the framers of the U.S. Constitution and Bill of Rights were strongly influenced by Locke's Second Treatise of Government. In it, Locke argues that government is created by the people and remains accountable to them. Government has the political power to make and enforce laws, but only for the public good.

\footnotetext{
${ }^{71}$ MELTON, Presley W.. Administration in a Federal Government Bureau. American Political Science Association, v. 33, n. 5, p. 840, out. 1939: "in his zeal for compliance with orderly procedure and intricate regulations, he may lose sight of the functions of the bureau. I know of no better way of bringing the worth of a bureau down to the deadest level of mediocrity and routine than by letting the business manager gain the upper hand completely. Some business managers have such a limited interest in what the bureau is really set up to do, but are so deeply engrossed in the method of doing it and in making sure that the method will keep them and the bureau out of trouble, that they get into the habit of anticipating troubles which never materialize. They forget that the regulatory agencies of the government - the General Accounting Office, the Civil Service Commission, the Budget Bureau, the Procurement Division - were set up to facilitate the work of the operating agencies, and are not an end in themselves. Perhaps this reaching out for more authority is simply a human trait confined by no means to government executive officers. The really competent executive officers in government, as in industry, are those who keep in mind constantly the objectives for which their bureau was set up and cooperate with the bureau chiefs in constantly reviewing and revising the administrative machinery whose purpose is helping achieve those objectives".
} 
E os autores (1995, p. 108) concluem, tendo por referência as vinte e uma regras sobre conduta dos administradores públicos estabelecidas por Carol Lewis (Lewis, Ethics Challenge, pp. 164-78), optando por reduzir tais regras a apenas cinco:

\author{
1. Obey and implement the law; \\ 2. Serve the public interest; \\ 3. Avoid doing harm; \\ 4. Take individual responsibility for the process and its consequences; \\ 5. Treat incompetence as an abuse of office.
}

Verifica-se, portanto, que o conceito de “compliance" adotado na doutrina internacional assemelha-se muito ao conjunto de princípios que regem a Administração Pública no ordenamento jurídico brasileiro, em especial os princípios da legalidade, da moralidade, da supremacia do interesse público e da eficiência.

Pode-se, ainda, registrar que o conjunto de regras de conduta adotado no “compliance” norte-americano também se assemelha a um padrão que deve ser buscado no direito público brasileiro, o da proteção à confiança do administrado, segundo o qual se pretende fortalecer a crença do cidadão de que as ações da Administração Pública sejam pautadas sempre pelo que estabelece o ordenamento jurídico nacional, dirigida ao atendimento do interesse público e evitando-se prejuízos à sociedade.

É forçoso reconhecer que o "compliance” assentado pela doutrina internacional acima citada coaduna-se perfeitamente com o ordenamento jurídico brasileiro atual, não apenas em uma dimensão relacionada à ética, mas também considerando a recente reforma administrativa e a mudança de foco da atuação da Administração Pública, que passou da burocracia tecnocrática para a atuação em serviço dos cidadãos.

Sob o aspecto da gestão financeira do Estado, o princípio da legalidade tem função primordial na governança republicana, pois que estabelece para o agente público os limites de sua atuação. Esses limites, diga-se, foram produzidos dentro do processo democrático, o que confere a legitimidade necessária para a atuação estatal e maior segurança ao cidadão, titular da res publica, mas que não participa diretamente da administração dos recursos públicos. 
Wilhelm Speck (2000, p. 152-153), ao tratar dos aspectos do controle de legalidade da atividade financeira do Estado, considera que

O controle da legalidade é implementado através de uma comparação das normas legais com as aplicações reais dos recursos. Os textos normativos mais importantes são aqueles referentes à definição periódica do orçamento federal. Normas permanentes de segmentação do orçamento para determinadas finalidades são outro marco legal que normatiza a aplicação de recursos orçamentários. Outros textos são igualmente relevantes, como o artigo 37 da Constituição, referente ao processo de contratação de pessoal, bem como de bens e serviços, pelo Estado. Finalmente, os princípios gerais da administração podem servir de referência para avaliar determinados procedimentos. O controle contábil visa comparar essas normas legais com a prática administrativa, apontando falhas e identificando responsáveis.

Sendo o princípio da legalidade um dos pilares da governança republicana, cabe ao aplicador do direito a sua observância como um dos vetores de interpretação das normas e atos relacionados com a atividade financeira do Estado.

Com referência à aplicação do princípio da legalidade, consoante as lições de Maria Sylvia Di Pietro (2009, p. 64), além dos artigos 37, caput, e $5^{\circ}$, II, da Constituição Federal,

[...] a observância do referido preceito constitucional é garantida por meio de outro direito assegurado pelo mesmo dispositivo (artigo $5^{\circ}$ da Constituição Federal), em seu inciso XXXV, em decorrência do qual 'a lei não excluirá da apreciação do Poder Judiciário lesão ou ameaça de lesão', ainda que a mesma decorra de ato da Administração. E a Constituição ainda prevê outros remédios específicos contra a ilegalidade administrativa, como a ação popular, o habeas corpus, o habeas data, o mandado de segurança e o mandado de injunção; tudo isso sem falar no controle pelo Legislativo, diretamente ou com auxílio do Tribunal de Contas, e no controle pela própria Administração.

A despeito da intensa adoção, na Administração Pública, de métodos gerenciais da iniciativa privada, em nome de maior agilidade e flexibilidade da gestão, as amarras impostas pelo princípio de legalidade respondem ao anseio da sociedade de que os administradores públicos se submetam à lei em benefício do interesse público ${ }^{72}$. A

\footnotetext{
${ }^{72}$ Cf. Kramer (KRAMER, Fred A.. Public management in the 1980 s and beyond. Implementing Governmental Change. Annals of the American Academy of Political and Social Science, v. 466, p. 102, mar. 1983), que entende que "public managers, however, have substantially less power to determine the basic goals of their agencies. Politics continually sets and resets program goals. Of course, as political
} 
submissão à lei e, de forma ampliativa, aos princípios, valores e regulamentos, aproximando-se do conceito de compliance, é a garantia de que os recursos públicos terão gestão justa e eficiente.

Theodore M. Smith (1975, p. 736-738) constatou que, em países em desenvolvimento, os gestores públicos não estavam acostumados à ideia de eficiência na gestão da coisa pública. Não obstante, as dificuldades enfrentadas pela máquina administrativa até hoje existentes, de contratação de pessoal qualificado, remuneração condizente com a atuação e manutenção dos servidores em seus quadros, são fatores que atrasam a evolução da Administração Pública. De fato, é preciso estabelecer instrumentos hábeis à ampliação do compliance na Administração Pública. A efetiva aplicação das sanções decorrentes da própria legislação, em caso de eventual descumprimento, e também os incentivos, com a finalidade de dirigir as ações da Administração para o objetivo adequado são caminhos para a boa gestão de recursos públicos.

Dessa forma, observa-se que o excesso de amarras ao administrador público, decorrente, entre outros fatores, da necessidade de observância do princípio da legalidade estrita, segundo o qual ao administrador público não é lícito fazer aquilo que não for expressamente autorizado por lei, não é uma questão exclusivamente brasileira.

Contudo, com a recente reforma administrativa e a necessidade de maior eficiência na gestão pública, além do foco da Administração Pública ter sido dirigido mais aos cidadãos do que às formalidades, o Direito Administrativo brasileiro tem sido constantemente atualizado pela doutrina e pela jurisprudência nacional, transformando-se a abordagem formalista em uma concepção mais consentânea com o interesse público, sempre em favor do atendimento pleno e eficaz das demandas da sociedade. Importante é que, em matéria de Direito Financeiro, o princípio da legalidade, aplicado e interpretado em conjunto com os demais princípios da administração, formam um sistema de governança republicana que protege os interesses da sociedade e do cidadão.

actors, career managers in the public sector can greatly influence the goals of their organizations. Few citizens, however, expect public managers - the often pejorative 'bureaucrats' - to run things. Rather than running things, citizens expect public managers to operate their agencies efficiently. Somehow, they seem to believe, if things operate efficiently, the agencies will also be effective". 


\subsection{Princípio da moralidade e a governança republicana}

Em um ordenamento jurídico de inspiração positivista como o brasileiro, a distinção entre o direito e a moral é constantemente abordada na doutrina e difundida nos cursos de Introdução ao Estudo do Direito, logo no início dos cursos de graduação.

Costuma-se distinguir entre o objeto do estudo da ciência do direito da moral comum, indicando-se como critério distintivo a existência de sanção por descumprimento das normas do Direito, aplicada por autoridades competentes legalmente instituídas na função de coibir o descumprimento das normas jurídicas, enquanto eventual descumprimento de normas morais não enseja aplicação de sanções, mas apenas gera sentimentos de natureza íntima nos indivíduos.

Reconhece-se, no entanto, que entre as esferas da moral e do direito há uma intersecção de normas que facilmente podem ser classificadas como oriundas tanto da moral como do direito, isto porque comumente o conteúdo de algumas normas morais, consideradas de fundamental importância pelos membros da sociedade, é inserido em normas jurídicas, tornando-se obrigatórias e passíveis também de sanções jurídicas em caso de descumprimento.

No direito brasileiro, contudo, a moralidade recebeu status de princípio constitucional, com sua inserção no caput do artigo 37 da Constituição Federal de 1988, como princípio que deve reger as atividades da Administração Pública direta e indireta de quaisquer dos entes federativos.

Não se pode admitir, no ordenamento jurídico brasileiro, que condutas imorais estejam em acordo com os preceitos jurídico-normativos. Neste sentido, cita-se a lição de Gilmar Ferreira Mendes e outros (2008, p. 56):

[...] pode-se dizer que a reverência que o direito positivo presta ao princípio da moralidade decorre da necessidade de pôr em destaque que, em determinados setores da vida social, não basta que o agir seja juridicamente correto; deve, antes, ser também eticamente inatacável. Sendo o direito o mínimo ético indispensável à convivência humana, a obediência ao princípio da moralidade, em relação a determinados atos, significa que eles só serão considerados válidos se forem duplamente conformes à eticidade, ou seja, se forem adequados não apenas às exigências jurídicas, mas também às de natureza moral. A essa luz, portanto, o princípio da moralidade densifica o conteúdo dos atos jurídicos, e em grau tão elevado que a sua inobservância pode configurar improbidade administrativa e acarretar-lhe a suspensão dos direitos 
políticos, a perda da função pública, a indisponibilidade dos bens e o ressarcimento ao erário, sem prejuízo da ação penal cabível, se a sua conduta configurar, também, a prática de ato tipificado como crime, consoante o disposto no $\S 4^{\circ}$ do art. 37 da Constituição.

Ainda no que concerne à distinção entre moral e direito e, especificamente, no ramo do Direito Administrativo, Maria Sylvia Zanella Di Pietro (2009, p. 75) recorda que

Antiga é a distinção entre moral e direito, ambos representados por círculos concêntricos, sendo o maior correspondente à moral e, o menor, ao direito. Licitude e honestidade seriam os traços distintivos entre o direito e a moral, numa aceitação ampla do brocardo segundo o qual non omne quod licet honestum est (nem tudo o que é legal é honesto).

A relação - muitas vezes íntima - entre direito e moral, especificamente no que tange à licitude e à honestidade da conduta no ramo do Direito Administrativo, por sua vez, pode ser explicada como originária do jusnaturalismo. Com efeito, o Direito Natural informa os princípios que embasam a moralidade administrativa, pois a conduta do gestor público e a aplicação das normas jurídicas devem ser pautadas pela honestidade e pela justiça.

Deve-se citar, ainda, que com a inserção da conduta do desvio de poder como ato ilegal - e não apenas imoral - na legislação nacional, o campo da moralidade administrativa foi reduzido, uma vez que algumas condutas de cunho moral passaram a ser avaliadas também sob a ótica da legalidade. Contudo, isso não impede que o direito positivo brasileiro continue reconhecendo a moralidade como um princípio ${ }^{73}$.

Embora nem todos os autores brasileiros aceitem a existência do princípio da moralidade administrativa, como bem destaca Maria Sylvia Di Pietro (2009, p. 75), sua autonomia sempre foi defendida por autores como Hely Lopes Meirelles e José Cretella Júnior, sendo certo que Diogo de Figueiredo Moreira Neto (2009, p. 104) assevera que a autonomia do princípio da moralidade administrativa foi inquestionavelmente reforçada pela explicitação conferida pela nova ordem constitucional, no artigo 37, caput, da Constituição Federal de 1988, afirmando a moralidade como um aspecto específico e singular do princípio da licitude.

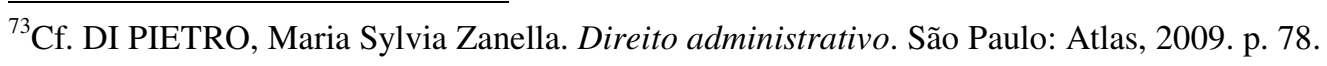


Para Hely Lopes Meirelles (2009, p. 90), Maurice Hauriou foi o sistematizador do conceito de moralidade administrativa. Para esse autor, a conduta externa do homem é delimitada pela moral comum. Por outro lado, o mesmo autor elucida que a conduta interna do administrador público é conformada pela moral administrativa em razão das determinações da sua instituição e, principalmente, do bem comum. Hauriou (1921, p. 424) define, ainda, a moralidade administrativa como o conjunto de regras de conduta tiradas da disciplina interior da Administração.

Deve-se registrar, no entanto, que moralidade administrativa é um conceito jurídico em aberto e não há definição objetiva de seu conteúdo, podendo-se aferir no que consiste o referido princípio a contrario senso.

Assim, Diogo de Figueiredo Moreira Neto (2009, p. 104-106) alerta para a distinção entre moralidade administrativa e moralidade comum, preceituando que “enquanto a moral comum é orientada por uma distinção puramente ética, entre o bem e o mal, distintamente, a moral administrativa é orientada por uma diferença prática entre a boa e a má administração”.

O citado autor entende a moralidade administrativa como uma espécie diferenciada da moral comum, que também atua como uma peculiar derivação dos conceitos de legitimidade política e de finalidade pública, uma vez que é a partir da finalidade, sempre legislada, que a moralidade é prevista em abstrato e, a partir da legitimidade, como resultado da aplicação, que ela se define em concreto $^{74}$.

Com a finalidade de delinear melhor o conteúdo do princípio da moralidade administrativa, o que será de grande valia no estudo da adoção de práticas de governança republicana aos atos de administração financeira do Poder Público, insta citar, uma vez mais, a lição de Diogo de Figueiredo Moreira Neto (2009, p. 105):

Portanto, para que o administrador vulnere este princípio, basta que administre mal os interesses públicos, o que poderá ocorrer basicamente de três modos: $1^{\circ}$ - através de atos com desvio da finalidade pública, para perseguir interesses que não são aqueles para os quais deve agir; $2^{\circ}-$ através de atos sem finalidade pública; $3^{\circ}$ - através de atos com deficiente finalidade pública, reveladores de uma ineficiência grosseira no trato dos interesses que lhe foram afetos.

\footnotetext{
${ }^{74}$ Cf. MOREIRA NETO, Diogo de Figueiredo. Curso de direito administrativo. 15. ed. Rio de Janeiro: Forense, 2009. p. 105.
} 
Em termos operacionais, a utilização de meios ilegítimos, como a traição da finalidade, tipificará formas de má administração da coisa pública e caracterizará a imoralidade administrativa, trazendo, como consequência, a anulação do ato.

[...] Para bem compreender o correto alcance dessa regra moral na Administração Pública, é preciso considerar que o dever cometido a seus agentes não é apenas o da mera gestão dos interesses públicos a eles confiados, mas, além dele, há, como se afirmou, o de bem administrá-los. Assim, enquanto a observância da moral comum é suficiente para qualquer administrador privado, o administrador público se sujeita, por acréscimo, a outras regras, estejam elas descritas ou não, que dele exigem fidelidade ao fim institucional de cada ato praticado na gestão da coisa pública - a moral administrativa.

Destarte, verifica-se que a moralidade administrativa, além de não se confundir com a simples moralidade comum e constituir princípio aplicável à Administração Pública por expressa disposição constitucional, implica, necessariamente, a boa gestão da coisa pública.

Assim, práticas de administração pública que não se conformem com a boa gestão e aplicação dos recursos públicos ensejam o questionamento - e eventuais sanções - à observância do princípio constitucional da moralidade administrativa.

Consoante anteriormente mencionado, o princípio da moralidade administrativa decorre do próprio princípio da legalidade. Nesse mesmo sentido, pode-se citar o entendimento de Celso Antônio Bandeira de Mello (2009, p. 120), para quem o princípio da moralidade significa um reforço ao princípio da legalidade e será tido como "transgredido quando houver violação de moral social que traga consigo menosprezo a um bem juridicamente tutelado".

$\mathrm{Na}$ tentativa de enumerar alguns bens jurídicos tutelados pelo princípio da moralidade administrativa, Maria Sylvia Di Pietro (2009, p. 77) esclarece que, dentre eles, podem ser destacados a moral, os bons costumes, as regras de boa administração, os princípios de justiça e equidade e a ideia comum de honestidade. Os quatro últimos, como se percebe, são bens jurídicos aplicáveis à gestão financeira do Estado, o que faz do princípio da moralidade outro pilar da governança republicana. 
Do princípio da moralidade administrativa podem ser extraídos alguns sub-princípios implícitos, tais como o dever de lealdade e a boa-fé, importantes para a boa gestão financeira e para a governança republicana ${ }^{75}$.

Hely Lopes Meirelles (2009, p. 93), por seu turno, ressalta que a moralidade administrativa se compara à boa-fé objetiva do Direito Privado, que é tida como um modelo de comportamento adequado a ser exigido de qualquer pessoa. $\mathrm{O}$ autor diferencia a moralidade administrativa da boa-fé subjetiva, que, nas palavras do autor, "denota estado de consciência ou convencimento individual de obrar em conformidade ao Direito”.

José Guilherme Giacomuzzi (2002, p. 291-303) defende a existência de dois distintos conteúdos para as "moralidades" previstas no artigo $5^{\circ}$ e no artigo 37 da Constituição Federal. Em relação à moralidade prevista no artigo $5^{\circ}$, Giacomuzzi afirma que a sua previsão no Direito brasileiro não é novidade, mas sim uma substituição do termo desvio de finalidade, que até então era pacificamente utilizado tanto no aspecto doutrinário quanto no legal. Na esfera constitucional, o autor relata que o Brasil provavelmente é um dos únicos, senão um dos dois únicos (já que o outro caso seria a Constituição colombiana) a prever esse princípio expressamente.

Giacomuzzi (2002, p. 297) critica veladamente a utilização do termo moralidade administrativa pelos juristas brasileiros ao afirmar, v.g., que "a jurisprudência que se seguiu à Constituição Federal de 1988 revela a nebulosidade e a falta de critérios racionais para apreender o real significado da moralidade administrativa”.

Giacomuzzi (2002, p. 298) destaca ainda que a moralidade administrativa sempre foi protegida no Brasil, principalmente após a edição da Lei da Ação Popular, o que é confirmado em sua exposição de motivos, a qual recorda ser o desvio de finalidade um dos seus objetos a serem combatidos.

Para concluir o seu pensamento sobre a moralidade do artigo $5^{\circ}$ da Constituição Federal, Giacomuzzi (2002, p. 299) esclarece que, no seu entendimento, “a moralidade administrativa do artigo $5^{\circ}$ é a legalidade interna do ato”.

\footnotetext{
${ }^{75}$ Cf. Celso Antonio Bandeira de Mello (MELlo, Celso Antônio Bandeira de. Curso de direito administrativo. São Paulo: Malheiros Ed., 2009. p. 119-120), para quem, "Segundo os cânones da lealdade e da boa-fé, a Administração haverá de proceder em relação aos administrados com sinceridade e lhaneza, sendo-lhe interdito qualquer comportamento astucioso, eivado de malícia, produzido de maneira a confundir, dificultar ou minimizar o exercício de direitos por parte dos cidadãos.
} 
Quanto à moralidade administrativa do artigo 37 da Constituição Federal, o autor (2002, p. 302) elucida que “[...] a principal - não a única - função da moralidade administrativa é veicular ao Direito Público o princípio da boa-fé, que vem do Direito Privado. A boa-fé objetiva, principalmente, porque a subjetiva está consubstanciada na improbidade administrativa, prevista no $\S 4^{\circ}$ do mesmo artigo 37 ”.

O princípio da moralidade administrativa dirige-se, inicialmente, aos administradores, investidos na função de gerir a coisa pública e cuja atividade deve ser voltada ao atendimento adequado do interesse público e das necessidades sociais. Trata-se, portanto, de norma a ser observada pelos administradores em benefício da coletividade, dos administrados.

Contudo, Maria Sylvia Di Pietro (2009, p. 77) preceitua que o princípio deve ser observado não apenas pelo administrador, mas também pelo particular que se relaciona com a Administração Pública. Neste sentido, cumpre ressaltar que o princípio da moralidade administrativa, de fato, deve ser observado por particulares também nas relações travadas com a Administração Pública. Pode-se citar também, como exemplo, as empresas concessionárias de obras e serviços públicos, que atuam em nome do Estado e, assim como o administrador, devem observar o princípio da moralidade administrativa na gestão tanto de recursos como de bens públicos que estiverem sob sua responsabilidade.

É íntima a relação entre moralidade e probidade administrativa, uma vez que a probidade administrativa também enseja a boa gestão da coisa pública e implica o cuidado do administrador público na conservação de bens públicos e sua correção na aplicação de recursos públicos, restando claro que os atos de improbidade administrativa são, em essência, atos de imoralidade administrativa.

A lei de improbidade administrativa ( $\mathrm{n}^{\circ}$ 8.429, de 02.06.1992), que dispõe sobre sanções aplicáveis aos agentes públicos nos casos de enriquecimento ilícito no exercício de mandato, cargo, emprego ou função na administração direta, indireta ou fundacional e dá outras providências, é mais um exemplo de integração de valores morais às normas jurídicas.

Com efeito, a referida lei, além de tipificar como atos de improbidade administrativa aqueles que causem prejuízo ao erário ou enriquecimento ilícito do agente público em detrimento do erário, também considera ato de improbidade administrativa as 
ações atentatórias aos princípios da Administração Pública - entre os quais se insere o princípio da moralidade - e, ainda, qualquer ação ou omissão que viole os deveres de imparcialidade, legalidade, honestidade e de lealdade às instituições, sendo certo que estes dois últimos também são considerados deveres inerentes à moralidade administrativa, conforme mencionado anteriormente.

Para Manoel de Oliveira Franco Sobrinho (1992, p. 248), a aferição de ato administrativo que afronta a moralidade comum social depende da análise da produção de seus efeitos, considerando, portanto, que "estará fora da moral comum social aquele ato administrativo que na sua eficácia: 1 . infringe a motivação; 2 . escapa da finalidade; 3 . não se apoia na exação”.

No que tange ao desfazimento do ato produzido em contrariedade à moralidade administrativa, José Afonso da Silva (2008, p. 336) comenta que:

[...] pode-se pensar na dificuldade que será desfazer um ato, produzido conforme a lei, sob o fundamento de vício de imoralidade. Mas isso é possível, porque a moralidade administrativa não é meramente subjetiva, porque não é puramente formal, porque tem conteúdo jurídico, a partir de regras e princípios da Administração. A lei pode ser cumprida moralmente ou imoralmente. Quando sua execução é feita, por exemplo, com o intuito de prejudicar ou de favorecer alguém deliberadamente, por certo que se está produzindo um ato formalmente legal, mas materialmente ofensivo à moralidade administrativa.

De qualquer forma, pode-se dizer que a atuação do administrador público em afronta às orientações legais e à má administração da coisa pública pode ensejar a apuração da observância da moralidade administrativa, com o consequente desfazimento do ato e apuração de responsabilidades. Contudo, reconhece-se a dificuldade para a aferição do descumprimento do princípio em comento, dado o caráter fluido e aberto do conceito normativo de moralidade administrativa anteriormente mencionado.

Cumpre registrar que a doutrina majoritária entende que o ato produzido em contrariedade à moralidade administrativa está sujeito à invalidação, conforme preceituam Celso Antonio Bandeira de Mello (2009, p. 119-120), Maria Sylvia Di Pietro (2009, p. 78) e Hely Lopes Meirelles (2009, p. 91).

Em relação ao controle de sua aplicação, Maria Sylvia Di Pietro (2009, p. 76) explica, em sua obra, que antigamente alguns, considerando a moral administrativa 
como algo relacionado à disciplina interna da Administração, entendiam que seu controle também só podia ser feito internamente, excluída a apreciação pelo Poder Judiciário, a quem competiria apenas examinar a legalidade dos atos da Administração; não o mérito ou a moralidade em sua produção.

Com efeito, tratando a legislação nacional de diversas questões relacionadas à moralidade e à probidade administrativas no exercício das funções de administrador público, o controle da moralidade administrativa pelo Poder Judiciário é plenamente admissível.

Como exemplo, além da lei de improbidade administrativa anteriormente citada, pode-se mencionar, entre outros, o artigo $2^{\circ}$ da lei da ação popular $\left(n^{\circ} 4.717\right.$, de 29.06.1965), que trata do desvio de finalidade; o artigo $2^{\circ}$, parágrafo único, IV, da Lei de processo administrativo ( $\mathrm{n}^{\circ}$ 9.784, de 29.01.1999), que determina a observância, nos processos administrativos, dos padrões éticos de probidade, decoro e boa-fé; e o artigo $9^{\circ}$ da lei $\mathrm{n}^{\mathrm{o}} 1.079$, de 10.04.1950, que classifica os crimes contra a probidade na Administração como crimes de responsabilidade.

Da mesma forma, o Egrégio Tribunal de Justiça de São Paulo (RDA 89, 134), em acórdão relatado pelo Des. Cardoso Rolim e também citado por Hely Lopes Meirelles (2009, p. 92), decidiu que “o controle jurisdicional se restringe ao exame da legalidade do ato administrativo; mas por legalidade ou legitimidade se entende não só a conformação do ato com a lei, como também com a moral administrativa e com o interesse coletivo".

A prática de atos em consonância com a moralidade administrativa também está sujeita ao controle de fidelidade funcional, especialmente com relação à gestão e utilização de recursos públicos. Com efeito, Maria Sylvia Di Pietro (2009, p. 741) destaca que o artigo 70 da Constituição Federal prevê a existência do controle de fidelidade funcional dos agentes da administração responsáveis por bens e valores públicos.

Este é um dos sentidos mais próximos da gestão financeira do Estado e, como se pode concluir, deve ser vetor de interpretação das normas de Direito Financeiro, por ser elemento do sistema de governança republicana. 
Manoel de Oliveira Franco Sobrinho (1974, p. 229) explorou bastante a questão da moralidade aplicada ao Direito Financeiro e, ao tratar da problemática envolvendo contas públicas, moralidade e responsabilidade, afirmou que

[...] no direito comparado, o que variam são os sistemas de fiscalização e controle. Todos, no entanto, levando a um mesmo fim. Objetivando duas situações. Uma de boa e legal exação na aplicação dos dinheiros públicos. Outra de vinculação funcional à responsabilidade no trato das coisas financeiras. Atuando sempre o princípio da moralidade. Princípio que aqui aparece consubstanciando regras que conduzem à licitude administrativa.

Ao estudar o sistema brasileiro, Manoel de Oliveira Franco Sobrinho (1974, p. 230) afirma que a "eticidade do Estado já deixou de ser um pressuposto, para ser uma condição de tranquilidade social no processo do desenvolvimento econômico".

A importância da observância ao princípio da moralidade administrativa no controle e fiscalização das contas públicas é acentuada por Manoel de Oliveira Franco Sobrinho (1974, p. 234), que argumenta que

[...] a extensão na fiscalização das contas públicas atende sobretudo o princípio da moralidade na Administração. O problema de discernir razões não é de transcendência metafísica, mas simplesmente problema de alta política administrativa. De modo geral, todos os organismos públicos integrados no corpo do Estado estão sujeitos à fiscalização financeira. Da mesma maneira, todos os organismos privados com participação estatal hão de sujeitar-se aos mecanismos de controle quando legais.

Considerando que o gestor público deve agir sempre com vistas ao interesse público e que cabe a ele a boa gestão financeira, protegendo a res publica com a melhor alocação possível dos escassos recursos públicos, não resta dúvida de que a moralidade, em todas as suas acepções, deve permear a sua conduta, cabendo às estruturas de governança republicana a garantia de efetiva aplicação deste princípio. 


\subsection{Princípio da eficiência e a governança republicana}

O princípio da eficiência foi inserido na Constituição Federal brasileira de 1988 apenas com a reforma administrativa ocorrida em 1998, por intermédio da Emenda Constitucional n ${ }^{\circ}$ 19, de 04.06.1998, que alterou a redação do caput do artigo 37 da Constituição, incluindo a eficiência dentre os demais princípios que devem reger a administração pública.

Odete Medauar (2006, p. 129) rememora que o princípio da eficiência não foi uma novidade trazida pela Emenda Constitucional $\mathrm{n}^{\circ} 19$ para o ordenamento jurídico brasileiro. Com efeito, relata a autora que tanto a Lei Orgânica do Município de São Paulo, quanto a Lei 8.987 de 1995, já o previam expressamente ${ }^{76}$.

Destarte, como se mencionou anteriormente, a eficiência na atuação do Poder Público já era uma construção doutrinária e, inclusive, já havia sido incorporada a diplomas normativos vigentes anteriormente à Emenda Constitucional no 19/98, sendo certo que sua inclusão na Constituição Federal, após dez anos de sua promulgação, garantindo-lhe status de princípio constitucional aplicável à Administração Pública, somente consolidou sua importância no Direito Constitucional e Administrativo pátrios.

O referido princípio tem relação íntima com a ideia de governança republicana aqui apresentada, sendo outro de seus pilares. Com efeito, para o Banco Mundial (1992), como já visto, “governança é a maneira pela qual o poder é exercido na administração dos recursos sociais e econômicos de um país para o seu desenvolvimento".

Com relação à concepção doutrinária do princípio, deve-se mencionar que Diogo de Figueiredo Moreira Neto (2005, p. 106) expõe que o princípio da eficiência é classificado como um princípio substantivo, que decorreu da "convergência de duas linhas de pensamento”. De fato, sobre a origem do conceito de eficiência não residir na Ciência do Direito, o autor assevera:

\footnotetext{
${ }^{76}$ Lei Orgânica do Município de São Paulo, de 4.4.1990:

Art. 123.

Parágrafo único. Ao usuário fica garantido serviço público compatível com sua dignidade humana, prestado com eficiência, regularidade, pontualidade, uniformidade, conforto e segurança, sem distinção de qualquer espécie.

Lei 8.987/95:

Art. $6^{\circ}$.

Parágrafo $1^{o}$. Serviço adequado é o que satisfaz as condições de regularidade, continuidade, eficiência, segurança, atualidade, generalidade, cortesia na sua prestação e modicidade das tarifas.
} 
[...] de um lado, o conceito de eficiência foi elaborado fora da Ciência do Direito, a partir da Revolução Industrial, ocasião em que começou a ser definido como a relação entre um produto útil e aquele teoricamente possível com os meios empregados, daí passando à Economia, onde se aproximou e até certo ponto se confundiu com o conceito de produtividade, ou seja, de uma relação mensurável ou estimável entre produto e insumos, daí chegando à administração privada e pública.

Não obstante, Moreira Neto $(2005,106)$ esclarece a origem do preceito na doutrina, indicando que a ideia jurídica de eficiência precedeu a Emenda Constitucional $n^{\circ}$ 19/98:

[...] de outro lado, destaca-se sua origem em estudos jurídicos doutrinários de vanguarda, desenvolvidos desde meados do século XX, por juristas do porte de Raffaele Resta e de Guido Falzone, no sentido de superar o conceito de poder-dever de administrar, afirmado pela administração burocrática, empenhada apenas em lograr a eficácia, para estabelecer, como um passo adiante, o dever da boa administração, que passou a ser respaldado pelos novos conceitos gerenciais, voltados à eficiência da ação administrativa pública.

Com efeito, a ideia de eficiência na atuação da Administração Pública decorre intrinsecamente da concepção de Administração Pública gerencial que tem sido recentemente adotada com a mudança de paradigmas a que se sujeitou o Direito Administrativo nas últimas décadas ${ }^{77}$. Adriana da Costa Ricardo Schier (2007, p. 47), ao se referir ao Plano Diretor da Reforma do Estado, observa, ainda, que

[...] no contexto da Reforma do Aparelho do Estado Brasileiro, verificouse, como se viu, a tentativa de implantar, no âmbito da Administração Pública, mecanismos da iniciativa privada. Tal intento pode ser verificado, principalmente, pelo conteúdo que foi atribuído ao princípio da eficiência, inserido no artigo 37, caput, da Constituição Federal de 1988, pela Emenda Constitucional n ${ }^{\circ} 19$ de 1998. Com efeito, a recepção desse princípio, no âmbito público, implica a busca pelo eficiente, determinado pelo que é mais lucrativo, menos oneroso.

Consoante mencionado anteriormente (no tópico referente ao princípio da legalidade), com a reforma do Estado, a atuação da Administração Pública passou a ser

\footnotetext{
${ }^{77}$ Cf. MOREIRA NETO, Diogo de Figueiredo. Curso de direito administrativo: parte introdutória, parte geral e parte especial. Rio de Janeiro: Forense, 2005.
} 
dirigida ao cidadão, em detrimento do formalismo excessivo que regia os atos praticados pelo Poder Público.

Neste sentido, Raquel Melo Urbano de Carvalho (2008, p. 192) destaca que "a modernização do Estado impõe-se a despeito da limitação dos recursos do erário e da impossibilidade de se onerar cada vez mais, via tributação, o cidadão-contribuinte".

Assim, o atendimento ao interesse público e aos administrados, como foco principal da atuação administrativa, enseja maior celeridade na atuação da Administração Pública e, ainda, o alcance de resultados concretos que beneficiem a população. Em decorrência disso, surgiram as ideias de deslegalização, instrumentalidade das formas, eficiência, gestão voltada a resultados, avaliações de desempenho e racionalização da atividade administrativa que culminaram pela inclusão do princípio da eficiência no texto constitucional, dez anos após sua promulgação.

Da mesma forma, José dos Santos Carvalho Filho (2008, p. 25) recorda que o princípio da eficiência era anteriormente denominado como qualidade do serviço prestado, no projeto que foi convertido na Emenda Constitucional no 19 de 1998.

Especificamente no que concerne à eficiência pública, Alexandre Santos de Aragão (2004, p. 1) leciona:

A eficiência não pode ser entendida apenas como maximização do lucro, mas sim como um melhor exercício das missões de interesse coletivo que incumbe ao Estado, que deve obter a maior realização prática possível das finalidades do ordenamento jurídico, com os menores custos possíveis, tanto para o próprio Estado, especialmente de índole financeira, como para as liberdades públicas dos cidadãos.

É também elucidativa a conceituação de eficiência administrativa por Diogo de Figueiredo Moreira Neto (2005, p. 107), que a compreende como

[...] a melhor realização possível da gestão dos interesses públicos, em termos de plena satisfação dos administrados com os menores custos para a sociedade, ela se apresenta, simultaneamente, como um atributo técnico da administração, como uma exigência ética a ser atendida, no sentido weberiano de resultados, e como uma característica jurídica exigível, de boa administração dos interesses públicos. 
Diógenes Gasparini (2004, p. 20) também discorre sobre a eficiência administrativa:

[...] conhecido entre os italianos como dever de boa administração, o princípio da eficiência impõe à Administração Pública direta e indireta a obrigação de realizar suas atribuições com rapidez, perfeição e rendimento, além, por certo, de observar outras regras, a exemplo do princípio da legalidade.

Raquel Melo Urbano de Carvalho (2008, p. 183) destaca que são requisitos para a concretização do princípio da eficiência tanto "uma gestão com efetiva participação democrática", como a "adequação técnica aos fins da Administração" e "um planejamento adequado da atividade pública seguido de uma execução aperfeiçoada, sujeita ao controle que assegure presteza, perfeição e rendimento funcional”.

Cumpre, ainda, citar Emerson Gabardo (2002, p. 146-147) que também discorre sobre o assunto:

O princípio constitucional da eficiência administrativa, expressado na Constituição Federal de 1988 pela Emenda Constitucional no 19/98, já era implícito à estrutura do regime republicano. Sua natureza jurídica é, portanto, inconteste, haja vista não só a sua formalização constitucional, mas, principalmente, a sua característica de princípio constitucional, cuja ontologia é inafastavelmente normativa. Assim sendo, o princípio não deve ser considerado uma mera transposição de um parâmetro da administração privada, nem implica uma derrogação de qualquer outro princípio constitucional, notadamente o da legalidade.

Verifica-se completamente plausível a existência de várias formas de aplicação tópica do princípio da eficiência administrativa, tanto como parâmetro de interpretação, quanto diretriz de organização e atividade administrativas. Na qualidade de mecanismo de controle dos atos administrativos e de responsabilização funcional do agente público, a explicitação da eficiência passa a incrementar o exercício da autotutela e a fiscalização social da atividade administrativa.

E, por fim, a respeito da possibilidade de controle da eficiência dos atos praticados pela Administração Pública e sua interpretação sistemática com os demais preceitos constitucionais, o autor conclui (2002, p. 147):

Torna-se clara a possibilidade de controle jurisdicional dos atos administrativos a partir da análise de sua eficiência, de forma independente, embora imbricada com os demais princípios constitucionais explícitos e, até mesmo, os implícitos, como o da 
razoabilidade e o da finalidade. Desse modo, amplia-se a possibilidade de acompanhamento da Administração por parte do Ministério Público, haja vista que a averiguação de ineficiência prescinde da existência de metas específicas, bem como pode ser realizada tanto a posteriori, como preventivamente à atuação administrativa, reforçando, portanto, o dever de sindicabilidade de quaisquer atos da Administração pelo Poder Judiciário.

Dalton Santos Morais (2004, p. 176), por sua vez, postula que

[...] a eficiência administrativa, como corolário da economicidade, tem uma vertente de maximização do recurso público a ser despendido pela Administração Pública, pelo que, para ser eficiente, a atividade administrativa empreendida deverá trazer benefícios para a coletividade compatíveis com o montante de recursos públicos despendidos.

Trata-se de princípio que deve ser utilizado como vetor de interpretação, a balizar o aplicador do direito. E não poderia ser diferente, pois se o princípio da eficiência não estivesse positivado em nosso ordenamento, tal omissão não autorizaria o agente público a agir de maneira ineficiente, ou seja, a eficiência é mandamental para o gestor público, independentemente da sua inserção no texto constitucional. Por essa razão, a existência do princípio no texto constitucional tem como finalidade direcionar o gestor para esse comportamento, permitindo, assim, o seu monitoramento e o controle institucional de sua aplicação.

Nessa linha, Dalton Santos Morais (2004, p. 189) reforça que

[...] a eficiência administrativa passa a ser vetor de interpretação de todas as demais normas de direito administrativo vigentes em nosso ordenamento jurídico, pois essa é uma das funções primordiais dos princípios de direito, ante sua impregnação por valores socialmente reconhecidos como mais importantes em determinado tempo e lugar.

Destarte, verifica-se que entre os bens jurídicos tutelados pelo princípio da eficiência administrativa, os recursos públicos ganham destaque no entendimento doutrinário, quanto à gestão e sua aplicação eficiente em prol da coletividade.

Conceito importante para a compreensão do alcance do princípio da eficiência é a chamada "reserva do possível", cuja definição pode ser encontrada em 
específico trabalho de Dalton Santos Morais (2004, p. 165), que trata da relação entre "os custos da atividade administrativa e o princípio da eficiência". Para o referido jurista, a reserva do possível é

[...] a construção doutrinária segundo a qual, havendo a fixação de um direito subjetivo passível de sindicabilidade judicial, o único limite a sua implementação recai sobre as reservas materiais, ou seja, as possibilidades econômicas e financeiras do Estado para tanto. ${ }^{78}$

Nessa linha, conclui o autor (2004, p.173-174) que "os direitos só existem se há recursos públicos suficientes para sua implementação pelo Estado”.

Raquel Melo Urbano de Carvalho (2008, p. 191) também observa que a reserva do possível "surge como elemento condicionador do prisma sob o qual deve ser compreendido o princípio da eficiência na Administração Pública brasileira".

Infere-se, portanto, que a cláusula da reserva do possível impõe limites à eficiência da gestão pública, ao passo que, embora a Administração deva atuar sempre de forma célere e eficaz no atendimento das necessidades públicas e do interesse público primário, não se pode exigir que todas as necessidades dos administrados sejam atendidas, dado que essas são infinitas, porém os recursos públicos para seu atendimento são limitados.

Além da finitude dos recursos públicos, a Administração Pública está sujeita a limitações fiscais e financeiras impostas pela legislação vigente, sendo certo que é necessário compatibilizar, inicialmente, a aplicação dos princípios da legalidade e da eficiência administrativa e, em um segundo momento, passar à ponderação dos interesses que exigem atendimento pelo Poder Público, de modo que sejam estabelecidas prioridades de atendimento com os recursos públicos escassos sob gestão do administrador público.

Com relação aos destinatários do princípio da eficiência administrativa, José dos Santos Carvalho Filho (2008, p. 25) assevera que

\footnotetext{
${ }^{78} \mathrm{Na}$ obra, o citado autor também menciona um julgado do Supremo Tribunal Federal (ADPF/MC - DF. Rel. Min. Celso de Mello. DOJ 29.04.2004. Disponível em: <www.stf.gov.br>) que estabelece: "condicionamentos impostos pela cláusula da "reserva do possível”, ao processo de concretização dos direitos de segunda geração - de implantação sempre onerosa - (que) traduzem-se em um binômio que compreende, de um lado, (1) a razoabilidade da pretensão individual/social deduzida em face do Poder Público e, de outro, (2) a existência de disponibilidade financeira do Estado para tornar efetivas as prestações positivas dele reclamadas".
} 
[...] o princípio da eficiência não alcança apenas os serviços públicos prestados diretamente à coletividade. Ao contrário, deve ser observado também em relação aos serviços administrativos internos das pessoas federativas e das pessoas a elas vinculadas.

Não obstante, da mesma forma que o princípio da legalidade, o princípio da eficiência administrativa destina-se a todos os gestores públicos, seja da Administração Pública direta ou indireta, que mantenham ou não vínculos efetivos com o Poder Público.

O referido princípio é também exigível de todos aqueles que, de alguma forma, utilizem ou administrem recursos públicos, dada a necessidade de prestação de contas da aplicação regular de tais recursos estabelecida no artigo 70, parágrafo único, da Constituição Federal e o fato de que qualquer aplicação de recursos públicos de forma ineficiente implica a responsabilização dos agentes que aplicaram tais recursos.

Por fim, deve-se registrar que o princípio da eficiência aplicável à Administração Pública também é dirigido aos administrados, em sentido lato, uma vez que eles são os beneficiários últimos da observância do referido princípio.

Ao tratar da possibilidade de se exigir da Administração Pública “qualidades intrínsecas de excelência”, Diogo de Figueiredo Moreira Neto (2005, p. 106) esclarece que elas "haverão, por certo, de ser numerosas, sendo, assim, imprescindível defini-las através de parâmetros objetivos, previamente fixados, destinados à aferição dos resultados alcançados pela ação administrativa".

Questão controvertida é a solução de conflitos entre os princípios da eficiência e da legalidade.

Para Alexandre Santos de Aragão (2004, p. 3), trata-se de privilegiar uma "legalidade finalística e material" em detrimento da antiga "legalidade meramente formal e abstrata”. No que tange à relação entre os princípios da proporcionalidade e da eficiência, Alexandre Santos de Aragão (2004, p. 4) revela existir um "conflito positivo”, porquanto os conhecidos requisitos do primeiro (necessidade e adequação) só podem ser cumpridos no caso concreto caso a solução adotada pelo administrador público seja a mais "eficiente e menos onerosa possível realização dos objetivos constitucionais que estiverem em jogo”. 
Do mesmo modo, Alexandre Santos de Aragão (2004, p. 5) enfatiza:

[...] não se trata de descumprir a lei, mas apenas de, no processo de sua aplicação, prestigiar os seus objetivos maiores em relação à observância pura e simples de suas regras, cuja aplicação pode, em alguns casos concretos, se revelar antiética àqueles. Há uma espécie de hierarquia imprópria entre as meras regras contidas nas leis e os seus objetivos, de forma que a aplicação daquelas só se legitima enquanto constituir meio adequado à realização destes.

Por sua vez, Humberto Ávila ${ }^{79}$, também citado por Raquel Melo Urbano de Carvalho (2008, p. 190), explana:

[...] não há o dever absoluto de escolher o meio que cause menos custo administrativo (Vewaltungsaufwand). A medida adotada pela administração pode ser a menos dispendiosa e, apesar disso, ser a menos eficiente. Só porque a medida é econômica não quer dizer que, em face da consideração de todas as circunstâncias deva ser adotada. Em segundo lugar, essas ponderações apontam para o dever de a administração escolher o meio menos dispendioso somente no caso de ficarem alteradas (ceteris paribus) a restrição dos direitos dos administrados e o grau de realização dos fins administrativos.

Diógenes Gasparini (2004, p. 21) entende que o desempenho das atividades da Administração Pública em prol dos interesses dos administrados em particular e da coletividade em geral deve ser rápido, sendo certo que qualquer procrastinação não seria passível de justificação, assentando que essa atitude pode levar a Administração Pública a indenizar os prejuízos que o atraso pode ter ocasionado ao interessado num dado desempenho estatal.

O referido autor rememora, ainda, antigo julgado do Supremo Tribunal Federal (RDA no 97, p. 177) em que ficou decidido que "a administração pública responde civilmente pela inércia em atender a uma situação que exige a sua presença para evitar a ocorrência danosa”.

Quanto aos aspectos perfeição e rendimento do princípio da eficiência e a relação custo-benefício que envolva quaisquer ações públicas, Diogenes Gasparini (2004,

\footnotetext{
${ }^{79}$ Revista Eletrônica de Direito Administrativo Econômico, Salvador, n. 4. (CARVALHO, Raquel Melo Urbano de. Curso de direito administrativo. Salvador: Juspodivm, 2008).
} 
p. 21) é cristalino ao pontuar que "a realização cuidadosa das atribuições evita desperdício de tempo e de dinheiro públicos, tão necessários na época atual”.

É, portanto, passível de responsabilização a atitude da Administração Pública em dissonância com o princípio da eficiência. Da mesma forma, em caso de condenação do Poder Público a indenizar um particular em função de atitude desidiosa, morosa e/ou ineficiente, há possibilidade de ação de regresso da Administração Pública contra o agente responsável, motivo pelo qual se pode mencionar a possibilidade de responsabilização civil, administrativa (no âmbito disciplinar) e até mesmo penal em situações em que a ação do agente público se enquadre no rol de crimes contra a Administração Pública, inseridos no Código Penal.

A respeito do controle da observância, pelo Poder Público, do princípio da eficiência administrativa, Caio Tácito (1992, p. 51) aponta que

[...] a par do controle externo, afeto ao Congresso Nacional, a Constituição impõe a cada qual dos Três Poderes a manutenção de sistemas de controle interno, destinados a avaliar o cumprimento de metas e programas de governo, a legalidade dos atos e a avaliação dos resultados, quanto à eficácia e eficiência da gestão.

No caso da eficiência com a gestão de recursos públicos, os sistemas de controle interno são de extrema importância, pois que eventuais ineficiências podem ser detectadas com maior rapidez e imediatamente serem tomadas as correções de rumo.

Com referência ao controle judicial, José dos Santos Carvalho Filho (2008, p. 26) menciona que

[...] atualmente, os publicistas têm apresentado vários estudos sobre a questão concernente ao controle da observância do princípio da eficiência. A complexidade que envolve o tema é compreensível: de um lado, há que se respeitar as diretrizes e prioridades e, de outro, não se pode admitir que o princípio constitucional deixe de ser respeitado e aplicado. Os controles administrativo (de caráter interno e processado pelos próprios órgãos administrativos) e legislativo são reconhecidamente legítimos e indubitáveis à luz dos artigos 74 e 70 da Lei Maior, respectivamente. O controle judicial, entretanto, sofre limitações e só pode incidir quando se tratar de comprovada ilegalidade. 
Raquel Melo Urbano de Carvalho (2008, p. 198) sugere que "a efetividade deve ser interpretada no sentido de princípio positivado em exclusivo benefício do cidadão, ampliativo de seus direitos, configurando mais um dever e parâmetro de controle da atividade administrativa pública”.

É, portanto, digno de nota que a doutrina não é unânime ao afirmar a possibilidade de controle judicial da observância, pelo Poder Público, do princípio da eficiência administrativa. Isto decorre, inicialmente, do conflito existente entre o mecanismo de checks and balances adotado pela Constituição Federal brasileira, por meio do qual todos os três Poderes têm atribuições de controle recíproco, cada um na esfera de suas atribuições, e da impossibilidade de invasão da esfera de competências de um Poder da República por meio de mecanismos limitados de controle a cargos dos demais Poderes $^{80}$.

Com efeito, a análise da eficiência na atuação da Administração Pública, especialmente em relação à implementação de políticas públicas sob responsabilidade do Poder Executivo, pode levar os demais Poderes a invadirem, ainda que minimamente, a esfera de competências do Executivo, passando a avaliar o mérito administrativo das escolhas realizadas pelo governo e as ações adotadas para a implementação de políticas públicas por ele estabelecidas, especialmente considerando que as necessidades públicas são infinitas, enquanto os recursos, por sua vez, são escassos.

É, contudo, cada vez mais comum que os Tribunais de Contas e o Poder Judiciário analisem o conteúdo das ações de governo, com vistas a examinar sua eficácia prática, extrapolando os antigos controles de simples legalidade ou financeiro que lhes eram atribuídos.

Isso, por um lado, coaduna-se melhor com o modelo de Estado gerencial adotado recentemente na Administração Pública nacional, com a desburocratização do Estado e a gestão pública dirigida a resultados que atendam, de forma eficaz, aos anseios dos cidadãos. Por outro lado, isso sempre será motivo de questionamento, dada a impossibilidade dos Poderes Judiciário e Legislativo invadirem a esfera de competência do Poder Executivo, dotado de legitimidade democrática para a escolha dos programas de governo e das políticas públicas que pretende implementar.

\footnotetext{
${ }^{80}$ Cf. ARAÚJO, Edmir Netto de. Curso de direito administrativo. 4. ed. São Paulo: Saraiva, 2009.
} 
Não obstante, o Poder Judiciário, invariavelmente, poderá ser provocado a manifestar-se contra atos atentatórios ao princípio da eficiência em ações de improbidade administrativa, por força do disposto no artigo 11 da lei $\mathrm{n}^{\circ} 8.429$, de 02.06.1992 ${ }^{81}$.

Com relação ao conteúdo do ato de improbidade administrativa contido no dispositivo legal acima citado, a doutrina majoritária e a jurisprudência concordam ao afirmar que o rol estabelecido, tanto no caput como em seus incisos, é meramente exemplificativo e, destarte, qualquer ato atentatório a princípios da Administração Pública pode constituir ato de improbidade administrativa.

Desta feita, tratando-se a eficiência de um princípio constitucional a ser observado no âmbito de toda a Administração Pública, competirá ao Judiciário avaliar, em cada caso concreto submetido à sua apreciação, se a inobservância ao princípio da eficiência ocorreu e, em caso afirmativo, se constituiu ato de improbidade administrativa.

Entretanto, a crítica que pode ser feita reside na ausência de objetividade na definição do que exatamente constitui a eficiência administrativa, o que torna sua aferição dificultosa e, eventualmente, a ação dos órgãos de controle pode carecer de uniformidade, gerando insegurança aos administradores públicos. Cabe ressalvar que o controle sistemático da eficiência possibilita a comparação entre situações análogas, o que facilita o acompanhamento da gestão pública, razão pela qual, mais do que as consequências jurídicas da responsabilização do agente público ineficiente, a obrigatoriedade de observância do princípio da eficiência, por meio de monitoramento permanente, interno e externo, é ferramenta de gestão, apta a propiciar diagnóstico mais preciso da alocação dos recursos públicos.

Neste sentido, deve-se, ainda, destacar que cada vez mais a Administração Pública tem se utilizado da avaliação de custo/benefício antes de tomar decisões quanto à implementação de políticas e o atendimento de determinadas necessidades, como forma de tornar mais eficaz a aplicação dos recursos públicos.

\footnotetext{
${ }^{81}$ Lei no 8.429, de 02.06.1992: Art. 11. Constitui ato de improbidade administrativa que atenta contra os princípios da administração pública qualquer ação ou omissão que viole os deveres de honestidade, imparcialidade, legalidade, e lealdade às instituições, e notadamente: I - praticar ato visando fim proibido em lei ou regulamento ou diverso daquele previsto, na regra de competência; II - retardar ou deixar de praticar, indevidamente, ato de ofício; III - revelar fato ou circunstância de que tem ciência em razão das atribuições e que deva permanecer em segredo; IV - negar publicidade aos atos oficiais; $V$ - frustrar a licitude de concurso público; VI - deixar de prestar contas quando esteja obrigado a fazê-lo; VII - revelar ou permitir que chegue ao conhecimento de terceiro, antes da respectiva divulgação oficial, teor de medida política ou econômica capaz de afetar o preço de mercadoria, bem ou serviço.
} 
José dos Santos Carvalho Filho (2008, p. 27) facilita a compreensão do princípio em comento ao distinguir precisamente os termos eficiência, eficácia e efetividade. Neste sentido, leciona o autor:

A eficiência não se confunde com a eficácia nem com a efetividade. A eficiência transmite sentido relacionado ao modo pelo qual se processa o desempenho da atividade administrativa: a ideia diz respeito, portanto, à conduta dos agentes. Por outro lado, eficácia tem relação com os meios e instrumentos empregados pelos agentes no exercício de seus misteres na administração; o sentido aqui é tipicamente instrumental. Finalmente, a efetividade é voltada para os resultados obtidos com as ações administrativas; sobreleva nesse aspecto a positividade dos objetivos. O desejável é que tais qualificações caminhem simultaneamente, mas é possível admitir que haja condutas administrativas produzidas com eficiência, embora não tenham eficácia ou efetividade. De outro prisma, pode a conduta não ser muito eficiente, mas, em face da eficácia dos meios, acaba por ser dotada de efetividade. Até mesmo é possível admitir que condutas eficientes e eficazes acabem por não alcançar os resultados desejados; em consequência, serão despidas de efetividade.

No que concerne à relação entre o princípio da eficiência e o Direito Financeiro, deve-se retomar, inicialmente, a lição de Raquel Melo Urbano de Carvalho (2008, p. 186-187), que afirma que não se pode mensurar as ações da Administração Pública com os mesmos critérios que orientam a atuação privada, sendo certo que não se pode medir valores que gozam de maior proteção no ordenamento jurídico pátrio em nome do cumprimento de metas exclusivamente financeiras.

Sob o aspecto da gestão financeira, o equilíbrio fiscal do Estado e a imposição de regras de responsabilidade fiscal à Administração Pública coadunam-se perfeitamente com a aplicação do princípio da eficiência à Administração Pública, pois as condutas da Administração Pública em consonância a responsabilidade fiscal permitem que sejam atendidas as necessidades primordiais da coletividade, o que, em essência, garante maior eficiência à aplicação dos recursos públicos, dadas as infindáveis necessidades sociais.

Ainda com relação à gestão dos recursos públicos, pode-se citar, uma vez mais, Raquel Melo Urbano de Carvalho (2008, p. 182), que aduz, ao tratar do controle sobre sua aplicação que

[...] encontra-se na Constituição da República, artigo 74, II, a regra segundo a qual cabe aos Poderes Legislativo, Executivo e Judiciário 
manter, de forma integrada, sistema de controle interno. A finalidade é de comprovar a legalidade e avaliar os resultados, quanto à eficácia e eficiência, da gestão orçamentária, financeira e patrimonial dos órgãos e entidades da administração federal, bem como da aplicação de recursos públicos por entidades de direito privado.

Segundo a mesma autora (2008, p. 185), o novo modelo (gerencial) reduz a importância do procedimento e ganha espaço o efetivo controle dos objetivos inicialmente fixados, pois "além da preocupação em obter a redução dos custos, tem-se um cuidadoso controle financeiro e de produtividade exercido em contrapartida à autonomia na gestão dos recursos reconhecida a quem exerce a atividade administrativa”.

Destarte, deve-se ressaltar que são as normas de Direito Financeiro, em especial as relativas à responsabilidade fiscal, que permitem que a Administração Pública busque a eficiência na gestão e aplicação de recursos públicos, dado que a cláusula da reserva do possível denota a difícil realidade prática enfrentada cotidianamente pelo Poder Público.

Outrossim, o estabelecimento de metas, prioridades e vedações fiscais relaciona-se intimamente com o modelo de Estado gerencial, voltado a resultados e que exige a avaliação do desempenho, da eficácia prática, decorrente das ações praticadas pela Administração Pública.

Por todo o exposto, com relação ao novo modelo de Estado gerencial, voltado a resultados práticos de suas atividades, ao atendimento do interesse público, à maior transparência, à atuação efetiva dos administrados mediante ampliação dos canais de democracia participativa, e à adoção de mecanismos que garantam maior eficiência na aplicação dos recursos públicos, a utilização de mecanismos de governança junto à Administração Pública, consoante será demonstrado no curso do presente trabalho, coaduna-se perfeitamente com os dispositivos normativos que regem o Direito Financeiro.

Neste sentido, pode-se citar Francisco Pedro Jucá (2008, p. 71-72) que indica que, atualmente, requer-se uma "Administração competente e de qualidade, como hoje se discute na Europa, onde se busca a qualidade de serviços e a eficiência de gestão em padrões de exigência típicos do mundo corporativo, norteado pela satisfação da sociedade e do cidadão”, o que o autor exemplifica ao referir à "obrigatoriedade da profissionalização da burocracia estatal”. 
É, portanto, inegável que a efetiva aplicação dos mecanismos de governança republicana por parte da Administração Pública garante a profissionalização em sua atuação, por meio da qual se busca conferir maior eficiência aos atos praticados pelo Poder Público, em especial, na gestão dos escassos recursos públicos.

\subsection{Princípio da economicidade e governança republicana}

A doutrina tradicional resistia à ideia de admitir a economicidade como um princípio efetivamente aplicável à Administração Pública, até sua positivação por meio da Constituição Federal de 1988. Nesse sentido, Jacoby Fernandes (1996, p. 154-156) aduz que o princípio da economicidade galgou um novo patamar com o advento da Carta de 1988.

É de rigor destacar que a avaliação da economicidade dos atos da Administração Pública foi conferida aos Tribunais de Contas, na qualidade de órgãos de controle externo, auxiliares do Congresso Nacional, por disposição contida no artigo 70 da Constituição Federal, cujo caput preceitua:

Art. 70. A fiscalização contábil, financeira, orçamentária, operacional e patrimonial da União e das entidades da administração direta e indireta, quanto à legalidade, legitimidade, economicidade, aplicação das subvenções e renúncia de receitas, será exercida pelo Congresso Nacional, mediante controle externo, e pelo sistema de controle interno de cada Poder.

Com efeito, Jacoby Fernandes (1996, p. 155) afirma que, até então, tanto a doutrina tradicional como a jurisprudência refutavam a possibilidade de que houvesse a revisão judicial do ato administrativo que ultrapassasse o aspecto da legalidade, o que impedia a apreciação do mérito e, por consequência, da própria economicidade. No entanto, o autor revela que, agora, com os artigos 70, 71 e 75 da Carta Maior, "a caixapreta do ato administrativo está aberta para os órgãos de controle. O instrumento da auditoria operacional é nitidamente de mérito e, pouco a pouco, vai sendo utilizado”.

Jacoby Fernandes (1996, p. 156) registra que, apesar da sua legalidade, o critério para aferir se um ato é ou não "antieconômico" é a sua maior ou menor inteligência ao visar à realização do interesse público. 
O autor também aponta que a economicidade como princípio administrativo não nasceu com a Constituição Federal de 1988, remetendo ao artigo 14 do Decreto-Lei $\mathrm{n}^{\mathrm{o}} 200$, de $1967^{82}$, que considera, ainda, não ter sido pioneiro no tema. Assim, o autor (1996, p. 154) assenta que "o princípio da economicidade existe há quase trinta anos e há mais de sete compete ao controle externo fiscalizar a sua efetivação”. Porém, recorda $\left(1996\right.$, p. 155) ${ }^{83}$ :

A doutrina estrangeira registra, mas recusa-se a adotá-lo como princípio do direito, recomendando cognominá-lo de "norma fundamental de economicidade" ou preceito de otimização, considerando que o mesmo não diz o que tem de ser otimizado, mas apenas que deve ser.

Brown Ribeiro (2003, p. 36) define economicidade como a "minimização dos custos dos recursos utilizados na consecução de uma atividade, sem o comprometimento dos padrões de qualidade”.

O ex-Ministro do Tribunal de Contas da União Paulo Affonso Martins de Oliveira (1989, p. 99), por sua vez, definiu economicidade como sendo "a qualidade do que é econômico. Em sentido lato, a arte de bem administrar ou administrar com racionalidade".

O Tribunal de Contas da União (1988, p. 183) costuma assentar que pelo princípio da economicidade, balizado pela razoabilidade, deve-se averiguar a relação entre custo e benefício, o que permitiria ao aplicador do direito verificar, no caso concreto, se houve ou não malversação de verba pública, sendo certo que esse princípio deve ser utilizado como instrumento de aferição da relação entre gasto público e benefício auferido,

\footnotetext{
${ }^{82}$ Art. 14. O trabalho administrativo será racionalizado mediante simplificação de processos e supressão de contrôles que se evidenciarem como puramente formais ou cujo custo seja evidentemente superior ao risco.

${ }^{83}$ A mesma observação foi feita por Francisco Carlos Ribeiro de Almeida (ALMEIDA. Francisco Carlos Ribeiro de. O controle dos atos de gestão e seus fundamentos básicos. Revista do Tribunal de Contas da União, Brasília, n. 80, p. 21, abr./jun. 1999), que afirma que "economicidade é princípio constitucional vazio, como acontece também com a igualdade. Enuncia a necessidade de adequação e equilíbrio entre o mínimo de despesa e o máximo de receita, nas melhores condições possíveis. Não passa de enunciado formal, porque não traz em si qualquer conteúdo ou determinação material, embora tenha por objetivo o controle dos aspectos materiais, da execução orçamentária. O jurista alemão Hans Herbert von Arnim, num livro dos mais completos e profundos sobre o assunto, intitulado Wirtschaftlichkeit als Rectsprinzip (Economicidade como Princípio Jurídico), recusa-lhe o status de princípio de direito, preferindo apelidá-la de "norma fundamental de economicidade" (Wirtschaftlichkeitsgrundsatz), caracterizando-a como um "preceito de otimização"(Optimierungsgebot), tendo em vista que não diz "o que deve ser otimizado, senão apenas que deve ser otimizado."
} 
quando então poder-se-á verificar se determinado fato ou ato administrativo atingiu seu objetivo maior, qual seja, garantir o atendimento do interesse público ${ }^{84}$.

O órgão de controle externo federal aduz, ainda, que o princípio da economicidade deve ser utilizado não somente como critério para avaliar o custo-benefício de um gasto, mas também para conferir o equilíbrio financeiro de contratos administrativos e, consequentemente, para aplicar sanções ao administrador, em caso de sua inobservância, uma vez que o art. 71, VIII, da Constituição Federal prevê aplicação de 'multa proporcional ao dano causado ao erário’ aos responsáveis.

O controle da economicidade conduz, portanto, ao controle da eficiência na gestão financeira e na execução orçamentária, consubstanciada na minimização de custos e gastos públicos e na maximização dos resultados almejados pela atuação pública.

Em relação ao princípio da economicidade, Paulo Affonso Martins de Oliveira defende que (1989, p. 99-100) “está diretamente ligado às Empresas Públicas, com o objetivo de minimizar custos e maximizar lucros”. Afirma o autor que este mandamento,

[...] tal como previsto na Constituição, vai muito além do existente na legislação ordinária (Decreto-Lei $n^{\circ}$ 200/67). Exige-se, hoje, do controle externo, o exame daquele princípio em todos os atos submetidos a julgamento do Tribunal de Contas e não somente na dispensa de controle na hipótese de custo do processo superar o risco do ato fiscalizado.

Assim, pode-se deduzir que, consoante afirmado pelo citado autor, "o princípio da economicidade associa o menor custo com o resultado obtido (custo-benefício)”.

Verifica-se, portanto, que os objetivos do princípio da economicidade consistem na avaliação do custo-benefício das medidas adotadas pela Administração Pública ao implementar suas políticas públicas.

Com efeito, tem se tornado cada vez mais comum, conforme anteriormente assentado no decorrer deste trabalho, que os órgãos de controle avaliem não apenas as despesas realizadas pela Administração, como também o resultado prático alcançado com a aplicação de recursos públicos, tais como o número de pessoas atendidas, entre outros diversos parâmetros que são analisados nas atividades - cada vez mais complexas - de controle dos gastos da Administração Pública.

\footnotetext{
${ }^{84}$ Referência: acórdão proferido nos autos da TC-012.085/96-0 - MMA - Possibilidade de introdução de modificações em contrato administrativo já pactuado - Relator Min. Lincoln Magalhães da Rocha.
} 
Jacoby Fernandes (1996, p. 157-158), em sua obra, cita exemplos práticos de controle da aplicação do princípio da economicidade ${ }^{85}$. Destaca-se que a aferição da observância ao princípio da economicidade é essencialmente mais frequente no âmbito de auditorias operacionais realizadas por Tribunais de Contas, que adentram o mérito dos atos administrativos, ao avaliar a eficiência, o custo-benefício e as alternativas possíveis aos atos praticados pelo Poder Público.

Não obstante, cumpre citar que há precedente do Superior Tribunal de Justiça $^{86}$, que demonstra que o Poder Judiciário também avalia, quando provocado, se as ações praticadas pela Administração Pública obedeceram ao princípio da economicidade, uma vez que referido princípio possui fundamento constitucional.

\footnotetext{
85“No âmbito do Distrito Federal, participamos de uma atuação notável do TCDF, que envolveu uma estatal local. Para desempenhar suas atividades, essa instituição possuía uma frota de veículos que se envolviam em acidentes com grande frequência: colisões, capotamentos, extremamente comuns. Acolhendo sugestão do Ministério Público que atua junto à Corte, decidiu o Tribunal promover diligências internas constatando que o volume de acidentes em determinado lapso de tempo superava o número de veículos da frota. Por economicidade estudou-se até a possibilidade de extinção da frota, fato que não chegou a ser efetivado porque outras providências, como a realização de perícias obrigatórias e a firme atuação no sentido de ordenar que motoristas passassem a recompor o erário, quando fossem os causadores do acidente, reduziu drasticamente o número de ocorrências. Foi precisamente o rigor na condução do processo de TCE (Tomada de Contas Especial), que gerou a mudança significativa". Mais adiante, o citado autor relata, ao se referir à decisão $\mathrm{n}^{\circ}$ 065 de 1995 (1 $1^{\text {a }}$ Câmara, julgado na sessão de 28.3.95) e à decisão no 95 de 1995 (Plenário, Rel. Min. Homero Santos, julgado na sessão de 8.3.95): "No TCU, examinando atos praticados por uma estatal federal de grande porte, típicos da atividade econômica, foi instaurada TCE, por terem sido consideradas lesivas ao erário as seguintes condutas: compra de mercadorias por preço superior ao praticado no mercado, aquisição de mercadorias em embalagens que faziam referência a partido político, comercialização de produtos por preços inferiores ao "preço de valoração dos estoques" definidos por uma portaria normativa, venda de grandes quantidades de produtos para uma empresa já sabidamente inadimplente com a estatal, venda de produtos não autorizada e que, na verdade, ao contrário do que alegava a direção do órgão, não estavam abaixo do padrão exigido pelas normas internas para consumo, pagamento de sobrestadia na importação de produtos, entre outras".

${ }^{86}$ ADMINISTRATIVO - RECURSO ORDINÁRIO EM MANDADO DE SEGURANÇA - CONCURSO PARA ADMISSÃO EM ATIVIDADES NOTARIAIS E REGISTRAIS - VACÂNCIA DE SERVENTIA EM RAZÃO DE FALECIMENTO DE SEU TITULAR ANTES DA HOMOLOGAÇÃO DE CONCURSO.

1. O art. 39 e $\$ 2^{\circ}$ da Lei 8.935/94 estabelece que ocorre a extinção da delegação a notário ou a oficial de registro com a morte do seu titular, cabendo à autoridade: declarar vago o respectivo serviço, designar o substituto mais antigo para responder pelo expediente e abrir concurso.

2. O edital do XXXVIII Concurso Público para Admissão nas Atividades Notariais e Registrais da Corregedoria-Geral de Justiça do Estado do Rio de Janeiro, no item 8.1., previu que os candidatos classificados seriam convocados para a escolha da serventia de sua preferência dentre aquelas publicadas no edital e as que vagassem até a data da homologação do concurso.

3. Hipótese dos autos em que o falecimento do titular da serventia ocorreu em 08/05/2006, a declaração de vacância em 29/05/2006 e a homologação do concurso em 23/05/2006.

4. A extinção da delegação ocorre, efetivamente, com o evento morte, ainda que posterior a declaração de vacância, ato administrativo meramente formal, que teve o condão apenas de declarar a existência de fato ocorrido anteriormente.

5. Ato da Corregedoria-Geral que ofereceu à escolha o $11^{\circ}$ Ofício de Registro de Imóveis da Capital do Rio de Janeiro que não contrariou a Lei 8.935/94, a Constituição Federal e tampouco aos princípios: do direito à disputa do serviço mediante prévia comunicação em edital; da publicidade; o democrático e o da isonomia. Ao contrário, atentou para o princípio da economicidade e da continuidade do serviço público, quando permitiu que um candidato, devidamente concursado, pudesse ocupar serventia vaga antes da homologação do concurso.

6. Recurso ordinário não provido.

(RMS 24928/RJ - Segunda Turma - Relatora Min. Eliana Calmon - Dje 18.04.2008 - v.u.).
} 
Constata-se, portanto, que a economicidade na prática de atos administrativos constitui qualidade reconhecida pelos órgãos de controle externo e judicial dos atos administrativos, o que impede que sua regularidade seja aferida pura e simplesmente a partir de uma avaliação formal da legalidade de tais atos. Segundo Francisco Carlos Ribeiro de Almeida (1999, p. 21),

A norma do art. 70 da Constituição Federal de 1988 distingue entre a fiscalização formal (legalidade) e a material (economicidade), sintetizadas no controle da moralidade (legitimidade), isto é, estabelece o controle externo sobre a validade formal, a eficácia e o fundamento da execução orçamentária. Mas o controle da legalidade não se exaure na fiscalização formal, senão que se consubstancia no próprio controle das garantias normativas ou da segurança dos direitos fundamentais; o da economicidade tem, sobretudo, o objetivo de garantir a justiça e o direito fundamental à igualdade dos cidadãos; o da legitimidade entende com a própria fundamentação ética da atividade financeira. De modo que o estudo sobre o papel institucional do Tribunal de Contas deve-se iniciar necessariamente pelo exame do relacionamento entre as finanças públicas e os direitos fundamentais.

Na mesma esteira, o referido autor enfatiza que

[...] a economicidade, que adquire voz constitucional no capítulo do controle (art.70), é, embora lá esteja implícita, um dos mais importantes princípios do orçamento público. Na Constituição da Espanha chega a aparecer na Declaração de Direitos e Deveres do Cidadão (art. 31, 2). Na Alemanha a Lei do Orçamento Federal (BHO), de 1969, diz, no art. $7^{\circ}$, que: '1. Devem ser observados na elaboração e na execução do orçamento os princípios da economicidade, da eficácia e da economia. 2. Devem ser realizados exames segundo o custo/benefício das medidas com a significação financeira relevante'; o regulamento daquela lei define a economicidade como a 'relação favorável entre os meios e os fins, que consiste em obter um certo resultado com a menor utilização de meios possíveis ou o melhor resultado possível com a utilização de certos meios'.

Não obstante, Caldas Furtado (2009, p. 334) conceitua controle de economicidade como a "verificação posterior (ex post) da eficiência". ${ }^{87}$ Para esse autor, "a

\footnotetext{
${ }^{87}$ “Nesse aspecto da fiscalização, analisa-se a eficiência na gestão financeira, operacional e patrimonial, através do exame da relação custo/benefício". O doutrinador passa, então, a tratar do Tribunal de Contas, o qual, no exercício dessa atividade, "quando detectar custos de bens e serviços registrados na contabilidade de ente público em valores acima dos razoavelmente aceitáveis, tendo em vista os preços de mercado - fato que caracteriza o denominado excesso de custos ou sobrepreço -, deve imputar débito contra o responsável (ordenador de despesas), objetivando a reparação do dano ao erário, por ocasião do respectivo julgamento das contas de gestão ( $\mathrm{CF}, 71$, II, e $\S 3^{\circ}$ ). Igual procedimento deve ser adotado no caso de glosa de despesa referente à compra de bens ou pagamento de serviços inexistentes (denominadas de obras fantasmas)".
} 
economicidade deve ter, à luz do Texto Constitucional, artigo 70, caput, aplicação maior, alcançando, além do simples exame das aquisições de bens e serviços pelo Poder Público”.

No que tange à importância do princípio da economicidade, Diogo de Figueiredo Moreira Neto (2005, p. 107) entende que,

[...] embora referido a propósito da execução da fiscalização contábil, financeira e orçamentária, o princípio da economicidade deve ser entendido como um princípio geral de Direito Administrativo, em razão de sua amplitude no desempenho da administração pública introversa.

De fato, a relação existente entre os princípios da economicidade e da eficiência é íntima, uma vez que se insere no princípio da eficiência a avaliação de custobenefício das medidas adotadas pela Administração Pública e, portanto, a maximização dos resultados alcançados pelas atividades da Administração que enseje o menor custo possível.

Por economicidade entende-se a devida consideração entre a relação de custo-benefício em prol das finanças públicas. Regis de Oliveira (1990, p. 94) a conceitua por meio da ponderação de "se saber se foi obtida a melhor proposta para a efetuação da despesa pública, isto é, se o caminho perseguido foi o melhor e mais amplo, para chegar-se à despesa e se ela fez-se com modicidade, dentro da equação custo-benefício". Já o Tribunal de Contas da União ${ }^{88}$ (TCU) conceitua essas dimensões, como:

- economicidade: minimização dos custos dos recursos utilizados na consecução de uma atividade, sem comprometimento dos padrões de qualidade.

- efetividade: relação entre os resultados (impactos observados) e os objetivos (impactos esperados).

- eficácia: grau de alcance das metas programadas em um determinado período de tempo, independentemente dos custos implicados.

- eficiência: relação entre os produtos (bens e serviços) gerados por uma atividade e os custos dos insumos empregados em um determinado período de tempo. O resultado expressa o custo de uma unidade de produto final em um dado período de tempo. Analogamente ao conceito de eficácia, pode-se estabelecer o grau de eficiência relativa de um programa, projeto ou atividade comparando-o com as metas e custos programados ou com dados de outras iniciativas que perseguem os mesmos objetivos. Nesse caso, somente serão comparáveis iniciativas

\footnotetext{
${ }^{88}$ TRIBUNAL DE CONTAS DA UNIÃO. Manual de Auditoria de Natureza Operacional, 2000.
} 
que, além dos objetivos, possuam as mesmas características de programação.

De fato, os conceitos de eficiência e economicidade estão interligados. Magno Antônio da Silva (2008, p. 71-84) assevera que, caso fosse possível expressar matematicamente o conceito de eficiência aplicado às Licitações Públicas, ter-se-ia a eficiência (E) como função direta da economicidade (e), da celeridade (c) e da qualidade (q), conforme o esquema a seguir: $\mathrm{E}=f(\mathrm{e}, \mathrm{c}, \mathrm{q})^{89}$.

A avaliação da economicidade dos atos administrativos, assim como da eficiência, não é fácil, uma vez que inexistem definições claras e objetivas do que seriam atos "econômicos" ou "antieconômicos". Entretanto, embora não existam indicações claras a esse respeito, a avaliação da economicidade deve seguir critérios objetivos e não subjetivos, razão pela qual deve ser sempre devidamente motivada.

Com relação à atuação das Cortes de Contas no controle da economicidade dos gastos públicos, Caio Tácito (1992, 45-53) aponta ser o Tribunal de Contas um meio preventivo de "garantia da boa gestão orçamentária" e que deve atuar “como fiscal da exação nas obrigações financeiras assumidas pelo Poder Público”. E elucida o autor:

O controle a ser exercido pelo Congresso Nacional, com o auxílio do Tribunal de Contas, vai além da legalidade. Dirige-se também à legitimidade e economicidade da gestão financeira, dilatando-se ao exame da aplicação de subvenções e aos casos de renúncia de receitas, ou seja, aos favores de incentivos fiscais (artigo 70 da Constituição Federal).

Destarte, é imprescindível reconhecer que, dada a amplitude do controle sobre a observância do princípio da economicidade pela Administração Pública, constitui referido princípio um instrumento importantíssimo no que concerne ao conhecimento da sociedade do conteúdo das políticas públicas e das atividades desenvolvidas pela Administração, tornando-as mais transparentes e democráticas, tendo em vista a possibilidade de questionamento popular de seu conteúdo, eficácia e economia.

\footnotetext{
${ }^{89}$ Neste raciocínio, afirma que "Nota-se, em linhas gerais, apesar da sutileza conceitual de cada termo, que a preocupação central da economia, da eficiência e da eficácia reside na redução de custos operacionais e na qualidade dos produtos ou serviços colimados. Percebe-se, então, que os conceitos expostos, no quadro supracitado, estão interligados."
} 
No que concerne à aplicação do princípio da economicidade no Direito Financeiro, Paulo Affonso Martins de Oliveira (1989, p. 82) afirma, especialmente considerando a alternância de governos inerente ao regime democrático adotado no Brasil, que

[...] há projetos que se desenvolvem durante longo tempo ou anos e que, na tradição política brasileira, um governo procura terminar os seus planos de obras dentro do seu mandato, compelido pela possibilidade que o sucessor, ao rever prioridades, adie ou reduza a intensidade do que vinha sendo feito, com graves prejuízos para o país e para o erário. Embora tenha havido grande melhoria de conduta nesse aspecto, isso ainda ocorre, em especial no âmbito dos Estados e Municípios. Tal comportamento não será mais admitido em razão mesmo do princípio da economicidade.

Ressalte-se, outrossim, que disto decorre a atuação da Administração Pública voltada aos cidadãos e ao atendimento precípuo do interesse público, da coletividade.

A aplicação do princípio da economicidade no Direito Financeiro cingese, portanto, à execução financeira e orçamentária pela Administração Pública, o que implica dizer que na atividade de aplicação de recursos públicos e no comprometimento do orçamento público com determinados programas e atividades, a Administração Pública deve sempre avaliar o custo-benefício envolvido, equacionando a realidade de escassez de recursos à infinidade de necessidades sociais a serem atendidas por sua atuação. Sua observância pelos agentes públicos, portanto, reflete-se em exercício da governança republicana.

\subsection{Princípio da publicidade e da transparência na governança republicana}

A publicidade constitui princípio aplicável à Administração Pública, por força do que dispõe o artigo 37, caput, da Constituição Federal de 1988.

Mais especificamente sobre a forma da publicidade de atos, campanhas e programas públicos, o $\S 1^{\circ}$ do artigo acima citado estatui:

$\S 1^{\circ}$ - A publicidade dos atos, programas, obras, serviços e campanhas dos órgãos públicos deverá ter caráter educativo, informativo ou de orientação social, dela não podendo constar nomes, símbolos ou imagens que caracterizem promoção pessoal de autoridades ou servidores públicos. 
Verifica-se, portanto, que o constituinte teve por objetivo, ao consagrar a publicidade como princípio constitucional aplicável à Administração Pública, assegurar que os administrados tenham conhecimento pleno das atividades praticadas pelo Poder Público e, munidos das informações necessárias, possam atuar também no controle das ações administrativas e, assim, exercer seu direito de participação popular, inerente ao modelo de Estado Democrático de Direito adotado no país e consentâneo à governança republicana.

A esse respeito, cabe citar a lição de Orion Augusto Platt Neto, Flávio da Cruz, Sandra Rolim Ensslin e Leonardo Ensslin (2007, p.78-79), in verbis:

Extrai-se do princípio da publicidade que o povo tem o direito de conhecer os atos praticados na administração pública, passo a passo, para o exercício do controle social, derivado do exercício do poder democrático. Destaca-se o "caráter educativo, informativo ou de orientação social" das divulgações, exigido pelo artigo 37 da CF/88 que revela a preocupação da assembleia constituinte com a compreensibilidade das informações para o controle social.

Os autores aduzem, ainda, que o ordenamento jurídico brasileiro prevê, de maneira complementar, várias normas que disciplinam a prestação de contas dos gestores públicos ao poder público e à comunidade em geral, o que também traduz a necessidade de divulgação das informações referentes à aplicação dos recursos públicos à sociedade, em clara externalização do princípio da publicidade ora comentado.

Esse aspecto é ressaltado pelo artigo $5^{\circ}$, XXXIII, da Constituição Federal, que estabelece:

Art. $5^{\circ}$.

XXXIII - Todos têm direito a receber dos órgãos públicos informações de seu interesse particular, ou de interesse coletivo ou geral, que serão prestadas no prazo da lei, sob pena de responsabilidade, ressalvadas aquelas cujo sigilo seja imprescindível à segurança da sociedade e do Estado.

Não obstante, insta ressaltar que as exceções à aplicação do princípio da publicidade, relativas à preservação da intimidade, encontram-se elencadas no artigo $5^{\circ}$, LX, da Constituição Federal, que se refere às hipóteses de sigilo, da seguinte forma: “a lei 
só poderá restringir a publicidade dos atos processuais quando a defesa da intimidade ou o interesse social o exigirem”.

$\mathrm{Na}$ hipótese, portanto, de conflito de interesses entre a preservação da privacidade dos cidadãos e a obrigatoriedade de publicidade dos atos, faz-se necessário que haja uma ponderação efetiva dos valores envolvidos, de modo a se atingir uma solução consentânea com os princípios que regem o ordenamento jurídico pátrio.

Outrossim, tanto a decretação de sigilo como a quebra dele deverão ser devidamente justificados, de modo que se demonstre os critérios adotados para a ponderação dos valores envolvidos, uma vez que tanto a privacidade como a publicidade possuem fundamento constitucional.

Do princípio da publicidade, consoante será demonstrado adiante, decorre a exigência de transparência dos atos praticados pela Administração Pública, como forma de concretizar o direito de acesso às informações relativas à gestão pública e de participação popular inerentes ao Estado Democrático de Direito.

Consoante mencionado, o princípio da transparência decorre diretamente do princípio constitucional da publicidade. Com efeito, embora não seja um princípio constitucional expresso, a doutrina o considera como um princípio implícito, dado o modelo de Estado adotado no Brasil e a positivação da publicidade e do dever de prestação de contas da aplicação dos recursos públicos no ordenamento jurídico brasileiro.

Neste sentido, pode-se citar a lição de Ricardo Lobo Torres (2001, p. 135), in verbis:

\begin{abstract}
A transparência fiscal é um princípio constitucional implícito. Sinaliza no sentido de que a atividade financeira deve se desenvolver segundo os ditames da clareza, abertura e simplicidade. Dirige-se assim ao Estado como à Sociedade, tanto aos organismos financeiros supranacionais quanto às entidades não governamentais. Baliza e modula a problemática da elaboração do orçamento e da sua gestão responsável, da criação de normas antielisivas, da abertura do sigilo bancário e do combate à corrupção.
\end{abstract}

Ricardo Lobo Torres (2001, p. 139) também contextualiza a necessidade de observância ao princípio da transparência em função da globalização, ressaltando a importância da transparência, na condição de instrumento que garante informações 
objetivas e claras à sociedade e como mecanismo de superação das contradições em um contexto global $^{90}$. Realmente, é importante registrar que a transparência passou a ser uma exigência constante em um mundo globalizado, de modo que alguns organismos internacionais adotaram, inclusive, a transparência como elemento norteador em suas relações, passando a exigir de países soberanos que sua atuação - seja em âmbito interno ou externo - seja consentânea com tal princípio ${ }^{91}$.

Para Sérgio Assoni Filho (2009, p. 85),

${ }^{90}$ Para Lobo Torres (TORRES, Ricardo Lobo. O princípio da transparência no direito financeiro. Revista de Direito da Associação dos Procuradores do Estado do Rio de Janeiro, Rio de Janeiro, v. 8, p. 139, 2001), “A globalização traz diversas consequências no plano da transparência fiscal, principalmente em decorrência da ambivalência que a cerca. A globalização produz a riqueza no plano universal e a pobreza no domínio local. Fortalece a cidadania mundial, pela afirmação dos direitos fundamentais; mas cria a miséria e a pobreza para a maior parte da população, o que postula a abertura da cidadania local à dimensão reivindicatória dos direitos sociais, sujeitos à concessão legislativa e ao reconhecimento orçamentário. Torna ameaçadores os riscos fiscais, assim pela insegurança dos capitais voláteis quanto pela diminuição da carga tributária das multinacionais. A transparência fiscal, como mecanismo de superação das contradições da globalização, entra simultaneamente no discurso das entidades supranacionais e das organizações locais”.

${ }^{91}$ Neste sentido, Ricardo Lobo Torres (TORRES, Ricardo Lobo. op. cit.) noticia que "O Banco Mundial, acusado de conduta opaca na concessão de empréstimos aos países em desenvolvimento, principalmente em virtude dos efeitos negativos sobre o meio ambiente, começa a mudar a sua posição a partir dos anos 90, na procura de maior transparência. Por pressão de organizações não-governamentais internacionais o Banco Mundial adotou em 1994 a política de abertura das informações (information disclosure policy), ao fito de colocar no domínio público os documentos antes considerados confidenciais e de incentivar a participação pública e o debate sobre o processo de desenvolvimento. O Fundo Monetário Internacional aprovou, em 16.4.98, o "Code of Good Pratices on Fiscal Transparency - Declaration of Principles", que "representa o modelo de transparência fiscal que é julgada apropriada para assegurar ao público e ao mercado que o desenho claro da estrutura e das finanças do governo é eficaz e que a saída da política fiscal pode ser estabelecida de forma confiável". O Code of Good Pratices contém quatro grandes princípios, com inúmeras subdivisões. A OCDE, da qual não participa o Brasil, também vem exercendo profícua atividade na defesa da transparência fiscal. Elaborou o modelo de Convenção, estampando no art. $9^{\circ} \mathrm{o}$ princípio arm's length, que teve por objetivo evitar a elisão fiscal nos preços de transferência. Divulgou e coordenou publicações sobre as leis de responsabilidade fiscal adotadas por diversos países, inclusive a Nova Zelândia e a Austrália. Vem se destacando no combate à corrupção, como se pode ver pela "Convenção para o Combate ao Suborno dos Funcionários Públicos Estrangeiros nas Transações Comerciais Internacionais".

Também Hélio Saul Mileski (MILESKI, Helio Saul. Transparência do poder público e sua fiscalização. Revista Interesse Público Especial, ano 4, v. esp. 2002. Responsabilidade Fiscal) cita a posição do FMI quanto à transparência: "O princípio da transparência dos atos de gestão fiscal assumiu tal relevância no concerto das nações, que o Fundo Monetário Internacional (FMI) resolveu elaborar um Manual sobre transparência fiscal, com disponibilização franqueada eletronicamente, contendo princípios específicos e normas referentes às boas práticas de gestão fiscal, com estas representando um padrão de transparência fiscal que é considerado, pelo FMI, apropriado para garantir ao público e aos mercados de capital que existe um quadro suficientemente completo da estrutura e das finanças do governo para permitir a avaliação fidedigna da solidez da posição fiscal dos países. Este Manual reflete o conteúdo do Código de Boas Práticas para a Transparência Fiscal, o qual tem estrutura organizacional fundada em quatro princípios gerais: (a) o primeiro princípio geral - Definição Clara de Funções e Responsabilidades - refere-se à especificação da estrutura e das funções do governo e o resto da economia; (b) o segundo princípio geral Acesso Público à Informação - enfatiza a necessidade de que se divulguem informações fiscais abrangentes a intervalos bem definidos; (c) o terceiro princípio geral - Abertura na Preparação, Execução e Prestação de Contas do Orçamento - cobre o tipo de informação divulgada a respeito do processo orçamentário e (d) o quarto princípio geral - Garantias de Integridade - trata da qualidade das informações fiscais e da necessidade de submetê-las a um escrutínio independente". 
Transparência e responsabilidade são termos que se relacionam vigorosamente no que concerne à gestão fiscal, pois vislumbrar uma forma de governo qualificada como democrática significa, antes de mais nada, ter em mente que todos os recursos financeiros estatais pertencem à coletividade, pois são obtidos, criados, geridos e gastos pelo EstadoAdministração em nome do interesse público. Nesta qualidade, eles são os meios materiais que servem de instrumento ao atendimento das necessidades públicas, portanto, sua utilização requer total comprometimento dos agentes estatais com a estrita consecução desta finalidade.

Em âmbito nacional, a legislação nacional tem, cada vez mais, dado ênfase à transparência na atuação da Administração Pública. Como exemplos, podem-se citar a Lei de Responsabilidade Fiscal, que será adiante melhor explorada, e o Código de Conduta da Alta Administração Federal, elaborado pela Comissão de Ética Pública ${ }^{92}$ e aplicável às autoridades da Administração Pública Federal. O referido documento, datado de 21.08.2000, expressa a preocupação da Administração Pública Federal com a clareza e a transparência das normas éticas aplicáveis às autoridades federais e dos atos praticados por tais autoridades. Neste sentido, pode-se citar trecho da exposição de motivos $n^{\circ} 37$, de 18.08.2000 ${ }^{93}$, que fundamenta a assinatura do referido documento:

Este Código, antes de tudo, valerá como compromisso moral das autoridades integrantes da Alta Administração Federal com o Chefe de Governo, proporcionando elevado padrão de comportamento ético capaz de assegurar, em todos os casos, a lisura e a transparência dos atos praticados na condução da coisa pública.

O princípio da transparência está positivado em outros ordenamentos, sendo que Ricardo Lobo Torres (2001, p. 140) relata, como exemplo, o projeto de lei italiano que cria o estatuto do contribuinte ${ }^{94}$. Também cumpre registrar que no Direito brasileiro a grande evolução na aplicação do princípio da transparência ocorreu com a edição da Lei de Responsabilidade Fiscal - LRF (Lei Complementar $\mathrm{n}^{\circ}$ 101, de 04.05.2000), que traz um capítulo especialmente destinado à 'transparência, controle e

\footnotetext{
${ }^{92}$ Criada por decreto de 26.05.1999.

${ }^{93}$ EXPOSIÇÃO DE MOTIVOS No 37, DE 18.8.2000. Aprovado em 21.8.2000. Câmara dos Deputados. Disponível em: <http://www.planalto.gov.br/ccivil_03/Codigos/codi_conduta/Cod_conduta.htm>.

${ }^{94}$ “Na Itália, o Senado aprovou, em 22.4.98, o projeto de lei do Governo em matéria de estatuto do contribuinte, que, entre outros, estampou o princípio da clareza e transparência dos dispositivos tributários, a proibição de retroatividade, a vedação de instituição de novos tributos por decreto-lei, a simplificação dos atos da administração financeira e a proteção da boa fé”.
} 
fiscalização' (artigos 48 a 59) ${ }^{95}$. De fato, ao fortalecer a transparência, a fiscalização e os instrumentos de controle, a LRF adotou posicionamento de valorização da cidadania e de participação da sociedade no monitoramento da gestão fiscal do Estado, configurando-se, assim, em instrumento de controle social, apto a colaborar no aprimoramento da gestão.

A transparência é abordada de maneira enfática na LRF, especialmente no Art. 48, que estabelece como instrumentos de transparência da gestão fiscal os planos, orçamentos e lei de diretrizes orçamentárias, as prestações de contas e o respectivo parecer prévio, o relatório resumido da execução orçamentária e o relatório de gestão fiscal ${ }^{96}$, e, ainda, as versões simplificadas desses documentos. Estabelecendo a obrigatoriedade de ampla divulgação, inclusive em meios eletrônicos de acesso público. A transparência será assegurada também mediante incentivo à participação popular e realização de audiências públicas, durante os processos de elaboração e de discussão dos planos, lei de diretrizes orçamentárias e orçamentos (LRF, Art. 48, Parágrafo único).

Desta feita, cumpre mencionar que, em âmbito interno, a transparência passou a ser adotada como importante instrumento de gestão fiscal e de controle, pela população, da aplicação dos recursos públicos na elaboração de políticas públicas,

\footnotetext{
${ }^{95}$ Orion Augusto Platt Neto, Flávio da Cruz, Sandra Rolim Ensslin e Leonardo Ensslin (PLATT NETO, Orion Augusto et al. Publicidade e transparência das contas públicas: obrigatoriedade e abrangência desses princípios na administração pública brasileira. Contabilidade Vista \& Revista, Belo Horizonte, v. 18, n. 1, p. 75-94, jan./mar. 2007) afirmam que "No ano de 2000, com a publicação da Lei Complementar n' 101, de 4 de maio, conhecida como Lei de Responsabilidade Fiscal (LRF), a exigência de transparência recebeu um novo reforço no âmbito estatal brasileiro. A LRF possui um capítulo sobre o tema, intitulado de "Transparência, Controle e Fiscalização" (artigos 48 a 59), enquanto que sua $1^{\text {a }}$ seção trata da Transparência da Gestão Fiscal, abrangendo os artigos 48 e 49.

${ }^{96} \mathrm{O}$ relatório de acompanhamento da gestão fiscal é composto por oito anexos, estabelecidos pela LRF e assim descritos: anexo I - demonstrativo da despesa com pessoal; anexo II - demonstrativo da dívida consolidada; anexo III - demonstrativo das garantias e contragarantias de valores; anexo IV demonstrativo das operações de créditos; anexo V - demonstrativo da disponibilidade de caixa; anexo VI demonstrativo dos restos a pagar; anexo VII - demonstrativo da despesa com serviços de terceiros; e anexo VIII - demonstrativo dos limites. O relatório resumido de execução orçamentária, já previsto na Constituição Federal de 1988, disciplinado pela LRF e pela Portaria no 560, abrangerá todos os Poderes e o Ministério Público e sua composição se dará por meio dos seguintes anexos: anexo I - balanço orçamentário; anexo II - demonstrativo da execução das despesas por função e subfunção; anexo III demonstrativo da receita corrente líquida; anexo IV - demonstrativo das receitas e despesas previdenciárias do regime geral de previdência social; anexo $\mathrm{V}$ - demonstrativo das receitas e despesas previdenciárias do regime próprio dos servidores públicos; anexo VI - demonstrativo do resultado nominal; anexo VII demonstrativo do resultado primário; anexo VIII - demonstrativo do resultado primário da união; anexo IX - demonstrativo dos restos a pagar por poder e órgão; anexo $\mathrm{X}$ - demonstrativo das receitas e despesas com manutenção e desenvolvimento do ensino; anexo XI - demonstrativo das receitas de operações de crédito e despesas de capital; anexo XII - demonstrativo da projeção atuarial do regime geral de previdência social; anexo XIII - demonstrativo da projeção atuarial do regime próprio de previdência social dos servidores públicos; anexo XIV - demonstrativo da receita de alienação de ativos e aplicação de recursos; anexo XV demonstrativo das despesas com saúde; anexo XVI - demonstrativo da receita líquida de impostos e das despesas próprias com saúde; e anexo XVII - demonstrativo da receita de impostos e das despesas próprias com saúde.
} 
programas e atividades que, consoante mencionado anteriormente, destinam-se, essencialmente, ao atendimento das necessidades públicas.

Helio Saul Mileski (2007, p. 89) também trata da transparência no âmbito da gestão fiscal, referindo-se a ela como um princípio orçamentário que também constitui um importante elemento de governabilidade, in verbis:

Portanto, a transparência fiscal é o mais novo e importante elemento de governabilidade do Estado, passando a constituir-se também em princípio orçamentário, na medida em que o processo orçamentário é fator essencial para a gestão fiscal. É este procedimento, de recentíssima incorporação ao direito financeiro, que será objeto de estudo no presente trabalho: a transparência fiscal.

Com efeito, embora a transparência decorra diretamente do princípio da publicidade, amplamente aplicável à Administração Pública, para o presente trabalho, importa o viés fiscal da transparência. Assim, a transparência, embora possa ser traduzida como o dever da Administração de fornecer informações relevantes, claras e objetivas aos administrados sobre quaisquer de seus atos, nesta oportunidade será adotada como aplicável essencialmente à gestão fiscal e à aplicação dos recursos públicos, seara em que mais se assemelha, consoante acima citado, com os aspectos de governança republicana.

A transparência, como se viu, pode ser traduzida como o dever da Administração Pública de fornecer aos cidadãos informações claras, relevantes e objetivas sobre quaisquer de seus atos, em decorrência lógica do princípio da publicidade, amplamente aplicável à Administração Pública, por força de disposição constitucional. Não obstante, na seara fiscal a transparência envolve, necessariamente, não apenas o fornecimento de informações claras a respeito das prioridades e metas estabelecidas pela Administração para aplicação dos recursos públicos em ações e programas indicados no orçamento fiscal, como também a necessidade de prestação de contas da gestão e aplicação desses recursos, bem como dos resultados atingidos pelos programas estabelecidos.

Neste sentido, cumpre citar a lição de Helio Saul Mileski (2007, p. 93), para quem o dever de transparência transborda a mera obrigação de publicação dos atos e informações sobre a gestão pública. De fato, para a concretização da governança republicana é preciso que o cidadão tenha acesso a informações completas e inteligíveis sobre o andamento das ações de governo, sendo possível à sociedade avaliar a execução 
dos programas e investimentos e a alocação dos recursos públicos. Mais do que isto, ao cidadão deve ser possível acessar informações detalhadas sobre as ações específicas de seu interesse, ou seja, de seu bairro, de sua comunidade, da escola do seu filho, do transporte público próximo de sua residência, além das demais questões a ele concernentes.

Nesse sentido, nas palavras de Hélio Saul Mileski (2007, p. 101),

Transparência não significa divulgar por divulgar, dar acesso a informação por dar. O sentido da transparência é promover a participação popular nos atos de governo, democratizando a gestão fiscal, a fim de que o cidadão, tendo conhecimento da ação governamental, possa contribuir para o seu aprimoramento e exercer um controle sobre os atos de governo, agindo em colaboração ao sistema oficial de controle da atividade financeira do Estado.

Resta claro que a transparência não enseja pura e simplesmente a divulgação de informações à sociedade, sendo este apenas um dos seus aspectos. Com efeito, para que a transparência se concretize é essencial que as informações sejam verdadeiras, relevantes, claras e objetivas, de modo que sejam compreensíveis por parte da população destinatária e permitam, assim, que a finalidade do referido princípio seja atingida, permitindo o exercício do controle e da participação popular sobre a gestão pública. A transparência não se concretiza mediante um atendimento meramente formal - e burocrático - do dever de divulgação de informações. Ao contrário, para que seja exercitada de forma legítima, é preciso que sejam conferidos às informações divulgadas os atributos da clareza e da simplicidade ${ }^{97}$. Isto se aplica não apenas às informações financeiras, como também a todos os atos praticados pela Administração Pública, inclusive de conteúdo normativo, dada a abrangência da aplicação do princípio da transparência.

Segundo Ricardo Lobo Torres (2001, p. 149), a transparência também pode ser concretizada mediante incentivo à participação popular e à realização de

\footnotetext{
${ }^{97}$ Para Orion Augusto Platt Neto et al. (op. cit.) “A transparência, como princípio da gestão fiscal responsável, pressupõe a publicidade e a compreensibilidade das informações. Esse aspecto também é destacado pelo Tribunal de Contas do Estado de Santa Catarina, que enfatiza que o princípio da transparência é mais amplo que o da publicidade, pois "a mera divulgação sem tornar o conteúdo compreensível para a sociedade não é transparência, como também não o é a informação compreensível sem a necessária divulgação". A transparência na LRF aparece como um "mecanismo para que a sociedade possa tomar conhecimento das contas e ações governamentais". Os referidos autores também exploram a transparência, apontando os três diferentes elementos que a compõem: "A partir da análise desenvolvida, intui-se que a transparência pressupõe três elementos ou dimensões: a publicidade, a compreensibilidade e a utilidade para decisões. Cada elemento complementa e interage com os outros para que a transparência seja plenamente propiciada".
} 
audiências públicas, com fundamento no que estatui a Lei de Responsabilidade Fiscal, em seu artigo 48.

Observa-se, portanto, que a doutrina nacional é pacífica ao afirmar que a transparência transcende a simples publicidade, assentando que, para que exista transparência efetiva, é necessário que a divulgação das informações à sociedade ocorra em momento oportuno, de forma clara, objetiva, compreensível e, ainda, que as referidas informações sejam relevantes para o exercício da cidadania por parte dos administrados.

No que concerne aos destinatários do princípio da transparência, Ricardo Lobo Torres (2001, p. 150) ${ }^{98}$ assevera que o referido princípio dirige-se tanto à Administração Pública como aos administrados, que deverão observá-lo.

Como mencionado anteriormente, a transparência é um mecanismo essencial à participação popular decorrente do modelo de Estado Democrático de Direito adotado na Constituição Federal de 1988. Neste sentido, cabe trazer a lição de Sérgio Assoni Filho (2009, p. 52) a respeito da essencialidade da participação popular em um regime democrático, in verbis:

O advento da forma democrática de governo, baseado na participação popular desempenhada de maneira direta pelos administrados, é fruto da superação da ideia de "representação" como a única forma possível de o povo influir na tomada de decisões governamentais nas atuais sociedades complexas.

A evolução institucional antes apontada, conjugando representação parlamentar e participação cidadã na gestão dos assuntos estatais, tem reflexos imediatos na Administração Pública, visto que esta é tornada irradiadora dos círculos do poder político, pois o exercício deste poder a partir dos próprios cidadãos-administrados traz à tona o legítimo interesse público, com a existência deste novo canal de expressão dos anseios sociais na cena política.

Têmis Limberger (2007, p. 259) também é enfática ao apontar a importância da transparência em regimes democráticos:

Um dos grandes objetivos das democracias da atualidade é possibilitar uma rede de comunicação direta entre a administração e os administrados que resulte em um aprofundamento democrático e em uma maior transparência e eficiência da atividade administrativa.

\footnotetext{
98“"A sociedade deve agir de tal forma transparente que no seu relacionamento com o Estado desapareça a opacidade dos segredos e da conduta abusiva fundada na prevalência da forma sobre o conteúdo dos negócios jurídicos. O Estado, por seu turno, deve revestir a sua atividade financeira da maior clareza e abertura, tanto na legislação instituidora de impostos, taxas, contribuições e empréstimos como na feitura do orçamento e no controle da sua execução".
} 
Sérgio Assoni Filho (2009, p. 256-258) conclui que a transparência, que permite que os cidadãos participem ativamente da gestão da coisa pública, é o instrumento necessário para a determinação das prioridades sociais e, consequentemente, para o atendimento do legítimo interesse público ${ }^{99}$.

Verifica-se, portanto, a relevância da análise do grau de transparência dos atos praticados pela Administração Pública, uma vez que dela decorre a efetividade dos instrumentos de governança republicana, bem como o nível de evolução da democracia em um determinado país.

A transparência na gestão pública está intimamente ligada à accountability $^{100}$, ou seja, ao dever de prestação de contas e respectiva responsabilização do agente público. Citando Ruth Richardson, Ricardo Lobo Torres (2001, p. 148) esclarece:

\footnotetext{
${ }^{99}$ Neste sentido, preceitua (ASSONI FILHO, Sérgio. Transparência fiscal e democracia. Porto Alegre: Nuria Fabris, 2009. p. 256-258) que "Por esse caminho, a participação cidadã na gestão da coisa pública dá ensejo a uma aproximação entre sociedade civil e Estado-Administração, com a partilha do poder decisório no que tange à determinação do que seja socialmente relevante, pois o exercício deste poder, a partir dos próprios cidadãos-administrados, traz à tona o legítimo interesse público, conquistando espaço na cena política a real expressão dos anseios sociais (...). Até porque essa estrutura poliárquica de exercício do poder requer que a constante aceitação de críticas, uma vez que a unanimidade é praticamente inatingível nas modernas sociedades complexas, de modo que a participação cidadã está fundada na busca pelo atingimento de uma espécie de consenso decisório referente aos rumos a serem seguidos pela Administração Pública em benefício da coletividade. Assim sendo, tal partilha tem como principal resultado prático alcançar a legitimidade no processo de tomada de decisões governamentais, materializada na atuação dos agentes públicos comprometida com os anseios populares captados junto ao corpo social. Dessa forma, o governo qualificado como democrático deve tornar a gestão estatal verdadeiramente de domínio público (...), tendo em vista que o cidadão comum ganha maiores subsídios para participar racionalmente na determinação das escolhas coletivas e, simultaneamente, o aparato estatal aprimora a sua percepção das necessidades sociais efetivas. A visibilidade dos atos e decisões governamentais tem como finalidade alcançar a transparência da gestão pública, no sentido de que esta última deve ser reconhecida pela busca efetiva de participação popular na determinação dos objetivos traçados pelos gestores, como fruto de um embate argumentativo ocasionado no meio social, do qual decorrem as propostas para implementação das políticas públicas."

${ }^{100}$ Orion Augusto Platt Neto et al. (PLATT NETO, Orion Augusto et al. op. cit.) estabelecem uma importante relação entre a transparência, accountability e governança corporativa. Neste sentido, preceituam os autores que o dicionários de contabilidade de Iudícibus, Marion e Pereira (IUDÍCIBUS, Sérgio de; MARION, José Carlos; PEREIRA, Elias. Dicionário de termos de contabilidade. 2. ed. São Paulo: Atlas, 2003), além de outros, não mostram definições do termo transparência. Tal fato indica que o tema transparência encontrase em estágio incipiente de desenvolvimento na Ciência Contábil. Todavia, Iudícibus, Marion e Pereira (op. cit., p. 118) quando tratam de governança corporativa mencionam que uma das qualidades da mesma é a transparência, fazendo uma associação direta entre esta com o termo disclosure. Segundo os autores, a governança corporativa representa um sistema que assegura aos proprietários e demais interessados uma gestão organizacional com equidade (fairness), transparência (disclosure), responsabilidade pelos resultados (accountability) e cumprimento de normas (compliance). $\mathrm{O}$ termo disclosure pode ser traduzido como evidenciação. O único dos dicionários de contabilidade consultados a abordar esse termo foi o de Iudícibus, Marion e Pereira (op. cit.). Segundo tais autores (Id. Ibid., p. 102), a evidenciação adequada, também chamada de evidenciação justa ou plena, é o processo de apresentação de informações que permitam a avaliação do sistema patrimonial e das mutações do patrimônio, além de possibilitar que se faça inferências sobre o futuro. Quanto à responsabilidade pelos resultados, Iudícibus, Marion e Pereira (op. cit.) resumem accountability como a "responsabilidade do gestor profissional de prestar contas".
} 
Ruth Richardson, ex-Ministra das Finanças da Nova Zelândia (19901993), oferece a seguinte explicação de accoutability: "o conceito de accountability precisa ser tão fundamental para o setor público quanto o é para o setor privado. Para ter sentido, a accountability precisa envolver níveis específicos de desempenho, liberdade administrativa para buscar os resultados e sanções por falhas. Portanto, uma relação efetiva de accountability exige: especificação antecipada dos níveis de desempenho; autoridade para determinar como os recursos serão empregados para produzir os resultados desejados; um processo de avaliação para saber se os resultados foram obtidos".

Têmis Limberger (2007, p. 258-259) aponta a accountability do direito anglo-saxão como fundamento da Lei de Responsabilidade Fiscal brasileira, lembrando que nos países com maior grau de transparência há níveis mais baixos de corrupção ${ }^{101}$.

Em virtude da amplitude do princípio da transparência, diversos autores desdobram referido princípio, apontando sub-princípios dele decorrentes. Nesta linha, Helio Saul Mileski (2007) define os seguintes princípios como princípios gerais: (i) princípio da definição clara de funções e responsabilidades; (ii) princípio do acesso público à informação estatal; (iii) princípio do acesso aos procedimentos de elaboração, execução e prestação de contas; e (iv) princípio das garantias de integridade das informações fiscais, de maneira semelhante ao contido no Manual sobre transparência fiscal elaborado pelo Fundo Monetário Internacional (FMI), já mencionado.

A respeito do princípio da definição clara de funções e responsabilidades, o autor menciona o dever de definir-se com clareza as funções, a estrutura e as responsabilidades do governo. Sobre o princípio do acesso público à informação estatal, o autor defende que a sociedade deve ser informada sobre os atos da administração, passados, presentes e futuros. Já com relação ao princípio do acesso aos procedimentos de elaboração, execução e prestação de contas do orçamento, o autor entende que é um dos momentos mais importantes para a vida do cidadão, uma vez que o estabelecimento de prioridades será definido por meio do planejamento orçamentário, razão pela qual a participação do cidadão é fundamental, o que só será possível com absoluta transparência. E, por fim, quanto ao princípio das garantias de integridade das informações fiscais, o autor preleciona que há necessidade de qualidade nas informações fiscais, qualidade essa

\footnotetext{
${ }^{101}$ Segundo o autor, "A Lei de Responsabilidade Fiscal se pauta pela transparência como norteadora do direito financeiro. Os artigos 48 e 49 compõem o capítulo da transparência, controle e fiscalização da gestão fiscal. A inspiração do texto legal foi concebida a partir da noção de accountability, do direito anglosaxão. A experiência de direito comparado aponta no sentido de que os países com informação mais
} 
que deve estar refletida na consistência e profundidade das informações, o que ele chama de integridade e confiabilidade.

A indicação de tais sub-princípios reforça a amplitude do conceito de transparência, conhecido como disclosure na doutrina dos países anglo-saxões, que exige do administrador público muito mais do que a simples publicação formal dos atos administrativos.

$\mathrm{Na}$ evolução do conceito desse princípio no Direito Financeiro, a Lei de Responsabilidade Fiscal é o instrumento normativo nacional que melhor absorveu os instrumentos destinados a conferir maior transparência à gestão dos recursos públicos ${ }^{102}$.

Em que pese a consagração da transparência na Lei de Responsabilidade Fiscal e a inegável evolução do Direito brasileiro no sentido de conferir à sociedade instrumentos mais adequados de controle social e até mesmo o constante aprimoramento da democracia nacional, que enseja cada vez maior participação popular e implica maior exigência social por transparência na gestão de recursos públicos, é inegável que muito ainda se pode avançar nessa seara. A garantia de efetividade dos instrumentos de governança republicana é providência que encontra perfeita consonância com a necessidade de que o Poder Público adote práticas cada vez mais transparentes, em benefício de toda a coletividade.

A despeito da universalidade desse princípio, a adoção de práticas transparentes pelo Poder Público não deve ser ilimitada, encontrando, desta feita, certas restrições. Com efeito, além de ser necessária a observância de eventual sigilo que recaia sobre determinadas informações e, ainda, o cuidado na seleção de informações cuja divulgação possa, de alguma forma, colocar em risco a segurança da sociedade ou do Estado $^{103}$. Diante disto, é essencial que exista um crivo sobre o conteúdo, uma vez que a

transparente são os que apresentam menores índices de corrupção. Deste modo, valendo-se dos mecanismos de divulgação eletrônica, os dados estarão disponíveis à população".

${ }^{102}$ Orion Augusto Platt Neto et al. (PLATT NETO, Orion Augusto et al. op. cit.) afirmam que as regras da LRF fundamentam-se em princípios inerentes à democracia, tais como a participação popular e a transparência. Neste sentido, apontam a íntima relação existente entre tais princípios, da seguinte forma: "A LRF fundamenta-se em princípios como o planejamento, a transparência e a participação popular. A participação popular, alicerce do controle social, depende fortemente da transparência das ações governamentais e das contas públicas, pois sem informações as decisões são prejudicadas. A transparência é um conceito mais amplo do que publicidade, isso porque uma informação pode ser pública, mas não ser relevante, confiável, tempestiva e compreensível. Mais do que garantir o atendimento das normas legais, as iniciativas de transparência na administração pública constituem uma política de gestão responsável que favorece o exercício da cidadania pela população. Assim, o presente artigo tem o objetivo de caracterizar a obrigatoriedade e abrangência dos princípios da publicidade e da transparência na administração pública brasileira, com enfoque na divulgação das contas públicas".

${ }^{103}$ Constituição Federal de 1988 - "Inciso XXXIII - todos têm direito a receber dos órgãos públicos informações de seu interesse particular, ou de interesse coletivo ou geral, que serão prestadas no prazo da 
amplitude de aplicação desse princípio não deve comprometer a segurança da sociedade ou do Estado. É óbvio que nessas condições deve haver sopesamento entre os dois princípios aparentemente conflitantes, prevalecendo a segurança da sociedade ou do Estado quando a publicidade do ato governamental os colocar em risco.

Ademais, deve-se considerar a quantidade e a pertinência das informações a serem divulgadas, de modo que a transparência das ações da Administração Pública seja realmente observada, não se divulgando informações inúteis, passíveis de sobrecarregarem e confundirem seus destinatários, impedindo que seja atingida a real finalidade do princípio em comento.

Para a concretização da transparência como prática permanente da gestão pública, Orion Augusto Platt Neto et al. (2007) listam alguns meios possíveis para que a sociedade tome ciência dos atos da Administração: meios presenciais, internet, meios impressos, televisão/rádio e meios inovadores, indicando exemplos de instrumentos passíveis de adoção pelo Poder Público em cada uma das categorias indicadas.

Não há dúvida de que a Internet é hoje a grande ferramenta para a transparência, pois que democratiza o acesso à informação de forma rápida e barata. As ações envolvendo o chamado e-governo já são realidade e tendem a se disseminar rapidamente em todas as esferas da administração pública, permitindo a qualquer cidadão a consulta imediata de informações sobre a gestão e sobre serviços públicos disponíveis.

O e-governo tem sido apontado como o principal fator de mobilização $\operatorname{cidadã}^{104}$ dentre as atuais ferramentas de inclusão participativa, e.g., orçamento participativo de Colônia, na Alemanha - primeira cidade da Europa com mais de 1 milhão de habitantes - que só pode realizá-lo graças à Internet.

Como dito, o avanço da tecnologia eletrônica permite que o processamento e a alocação dos dados sejam realizados e tornados públicos com eficiência e eficácia. É, sem dúvida, o maior golpe contra a assimetria de informações, fomentando a "democracia digital". Com a tecnologia da informação hoje disponível, a Administração

lei, sob pena de responsabilidade, ressalvadas aquelas cujo sigilo seja imprescindível à segurança da sociedade e do Estado;"

${ }^{104} \mathrm{Cf}$. CHADWICK, Andrew; MAY, Christopher. Interaction between States and citizens in the age of internet: e-government in the United States, Britain and the European Union, Governance. An International Journal Policy, Administration and Institutions, Oxford, v. 16, n. 2, p. 1, Abr. 2003. 
pode colocar à disposição do cidadão verdadeiras salas de situação ${ }^{105}$, com o monitoramento em tempo real da execução financeira e orçamentária, vinculadas à implementação das políticas públicas e investimentos ${ }^{106}$.

A despeito de seu potencial, essa nova ferramenta ainda precisa ser universalizada, bem como é preciso que a sociedade saiba que pode encontrar as informações na rede mundial ${ }^{107}$. Sob o aspecto da transparência fiscal, não há dúvida de que a rede mundial é o instrumento mais poderoso à disposição da sociedade.

Apenas como ilustração, pode-se mencionar também o exemplo recente da implantação do Portal dos Convênios do Governo Federal (www.convenios.gov.br), sistema informatizado por meio do qual todos os convênios em âmbito federal deverão ser celebrados, acompanhados, fiscalizados e executados, por força do que dispõe o decreto $\mathrm{n}^{\circ}$

\footnotetext{
${ }^{105}$ Marluce Araújo Assis e Tereza Scatena Villa (ASSIS, Marluce Araújo; VILLA, Tereza Scatena. O controle social e a democratização da informação: um processo em construção. Revista Latino-Americana de Enfermagem, Ribeirão Preto, v. 11, n. 3, maio./jun. 2003) noticiam a iniciativa de implantação de salas de situação na área da saúde pública: "Algumas iniciativas têm sido tomadas para o fortalecimento de uma rede que possibilite disponibilização de informações voltadas ao conhecimento e compreensão da realidade sanitária brasileira (...) As salas de situação retratam essas iniciativas importantes e consiste em instrumento de grande relevância no exercício do controle social, tendo em vista a utilização de instrumentos de ação por meio de dados demográficos, geográficos, epidemiológicos, socioeconômicos, financeiros e de produção de serviços que deverão ser expostos para os Conselhos de Unidades e Municipais de Saúde, trabalhadores de saúde e qualquer cidadão interessado em constituir parte das informações; bem como na construção de home-pages municipais".

${ }^{106}$ Cf. Domingos Castro Poubel e Leice Maria Garcia (CASTRO, Domingos Poubel de; GARCIA, Leice Maria. Contabilidade pública no Governo Federal. São Paulo: Atlas, 2004. p. 92). Nesse campo, uma das iniciativas mais revolucionárias foi a adoção dos sistemas integrados de gestão financeira, tanto na esfera federal (SIAFI), como em outros entes da federação. Tais sistemas permitiram maior agilidade e confiabilidade na gestão fiscal.

${ }^{107}$ Orion Augusto Platt Neto et al. (PLATT NETO, Orion Augusto et al. op. cit.) falam sobre o uso da internet como instrumento de transparência: "A Internet, como meio para o fortalecimento das relações entre o governo e o cidadão, tem sido alvo de muitos estudos atuais. A esse respeito, destaca-se a atuação do Congresso de Informática Pública (CONIP), principal fórum brasileiro de discussão e apresentação de iniciativas de modernização do serviço público, atendimento ao cidadão, gestão administrativa e das finanças públicas.No entanto, menos de $12 \%$ da população brasileira é usuária da Internet, gerando o chamado apartheid digital. E as limitações de acesso à rede não terminam aí. Desses usuários, grande parte ainda desconhece os potenciais da rede mundial de computadores e as páginas governamentais não estão em sua rotina na navegação, mesmo por questões culturais.A primeira iniciativa legal no sentido de incorporar a obrigatoriedade da divulgação de informações das contas públicas na Internet surgiu por meio da Lei $n^{\circ}$ 9.755/98, que criou a página da Internet Contas Públicas (<www.contaspublicas.gov.br>). Nessa página, todas as entidades gestoras de recursos públicos são obrigadas a disponibilizar determinadas informações orçamentárias e financeiras mensalmente. Desse modo, estão abrangidas as entidades públicas das esferas federal, estadual e municipal, da administração direta e indireta, autárquica e fundacional, de todos os Poderes. Para orientar a correta utilização da página Contas Públicas, o Tribunal de Contas da União (TCU), editou a Instrução Normativa $n^{\circ} 28$, de 5 de maio de 1999 e a Portaria n $^{\circ} 275$, de 14 de dezembro de 2000. (...) A divulgação de informações governamentais na Internet está inserida dentro das iniciativas de Governo Eletrônico (E-gov). Particularmente nas relações do tipo governo-cidadão (G2C) e governo-empresa (G2B). Para seus idealizadores, o E-gov pode ser compreendido como uma ferramenta democrática de capacitação política da sociedade. Como iniciativa de E-gov, cita-se o Redegoverno, um portal de serviços e informações do governo brasileiro e o portal Obrasnet (<www.obrasnet.gov.br $>$ ), que disponibiliza diversas informações sobre obras públicas realizadas e em andamento, do Governo Federal, entre outras”.
} 
6.170/07 e a portaria interministerial MP/MF/CGU $n^{\circ}$ 127/08. Insta mencionar que o referido Portal tem por finalidade, também, servir de meio para a realização de chamadas públicas previamente à celebração de convênios e para a divulgação das informações relativas ao ajustes celebrados pela União para toda a sociedade, que poderá acompanhar seu desenvolvimento, constituindo-se, portanto, em efetivo instrumento de transparência na realização de repasses de recursos da União a outros órgãos públicos ou entidades sem fins lucrativos.

A exigência de transparência como forma de assegurar aos cidadãos o exercício de seu direito à participação popular decorrente do modelo de Estado Democrático de Direito também, por si só, pode não produzir os efeitos almejados. É necessário assegurar que o referido princípio seja efetivamente observado e colocado em prática no seio da Administração Pública.

Em função disso, o controle da atividade pública tem também por finalidade fomentar a observância ao princípio da transparência por parte dos gestores públicos e impor sanções àqueles que o descumprirem. Para tal, como qualquer instrumento de governança, não basta a existência de normas legais, mas também de um sistema de controle e responsabilização do agente público que se omitiu nesse dever. Esclarecendo a finalidade da atividade de controle interno e a forma de sua execução, Hélio Mileski (2007, p. 103) explica que

O controle assim realizado permite prevenir riscos e corrigir desvios capazes de afetar o equilíbrio das contas públicas, na medida em que o acompanhamento da gestão fiscal das Administrações Públicas deve ser realizado bimestral, quadrimestral ou semestralmente através de relatórios e demonstrativos parciais, na forma legal regulada. Ao final de cada exercício, haverá a consolidação desses relatórios parciais, resultando na prestação de contas anual da gestão fiscal.

Bem que se diga que a legislação brasileira possui instrumentos aptos a impor a transparência nos atos de gestão fiscal e ainda apresenta diversas sanções por seu descumprimento, de modo a incentivar que os gestores públicos sempre ajam de forma transparente, penalizando aqueles que omitirem informações da sociedade, impedindo que o direito à participação popular seja exercido e, desta forma, o controle social seja realizado. Contudo, deve-se registrar que esses mecanismos de governança republicana, muito embora muito bem posicionados no sistema jurídico vigente, precisam ser 
efetivamente aplicados, tanto pelos três Poderes, como pelo Ministério e principalmente pela sociedade. Dessa forma, têm muito a contribuir para o fomento cada vez maior de respeito ao princípio da transparência e, assim, garantir o controle social sobre os atos de gestão fiscal. 


\section{GESTÃO FINANCEIRA ESTATAL E GOVERNANÇA REPUBLICANA}

O Direito Financeiro, "disciplina jurídica da atividade financeira do Estado", na acepção de Régis de Oliveira (2008, p. 84), regula todos os aspectos da gestão dos recursos públicos, desde o planejamento orçamentário até o controle da execução financeira.

Ives Gandra Martins (2001, p.136) resume afirmando que "[...] finanças públicas é gênero e diz respeito a tudo o que pertine às receitas e despesas públicas [...]”.

$\mathrm{Na}$ definição de Dino Jarach (1996, p.37), “Las finanzas públicas constituyen la actividad económica del sector público con su peculiar estructura que convive con la economia de mercado, en una suerte de asociación biológica o simbiosis".

No âmbito das finanças públicas incluem-se todas as questões relativas, de um lado à obtenção de recursos públicos, abrangendo todas as espécies de receitas, o financiamento público e as transferências intergovernamentais de recursos, e, de outro, os gastos, neles contidos os dispêndios com a prestação de serviços públicos, com a manutenção da máquina administrativa, com investimentos e com o pagamento de juros e principal da dívida pública, além de todas as atividades voltadas ao planejamento e ao controle orçamentário $^{108}$. Para os fins deste capítulo, serão abordadas as questões relativas ao planejamento orçamentário, à eficiência do gasto público e à responsabilidade fiscal, sempre com foco nos instrumentos de governança republicana.

Alberto Deodato (1984, p.15) entende que o papel do Estado é satisfazer as necessidades públicas ou coletivas, sendo a atividade financeira nada mais do que um dos principais instrumentos para o exercício de seus misteres.

\footnotetext{
${ }^{108}$ Cf. Ruy Barbosa Nogueira (NOGUEIRA, Ruy Barbosa. Direito tributário comparado. São Paulo: Saraiva, 1971. p. 33), para quem "O direito financeiro é, pois, o ordenamento jurídico total das atividades financeiras do Estado, as quais compreendem a receita, a despesa, o orçamento e o crédito públicos. O Direito Tributário é um capítulo do Direito Financeiro e ele se refere àquela parte da receita que diz respeito ao fenômeno jurídico da relação entre tesouro público e contribuinte". Também Ricardo Lobo Torres vê o Direito Tributário como um subsistema do Direito Financeiro que foca o lado das receitas. Já o professor Regis de Oliveira entende que não há autonomia do Direito Tributário, que tem normas e princípios pertencentes aos ramos do Direito Administrativo e do Direito Financeiro. Por fim, Dejalma de Campos (CAMPOS, Dejalma de. Direito financeiro e orçamentário. São Paulo: Atlas, 2001) classifica o Direito Tributário como o ramo que "[...] regula uma das atividades financeiras do Estado: a receita pública advinda da arrecadação de tributos".
} 
Em verdade, a atividade financeira do Estado permeia todas as ações da administração pública, pois sem recursos não há investimentos, nem tampouco serviços públicos.

Em um momento de grandes turbulências financeiras no mundo globalizado, como foi a última década do século $\mathrm{XX}$, os organismos internacionais fomentaram a adoção de práticas de boa gestão fiscal como requisito para $o$ desenvolvimento econômico ${ }^{109}$. Em suma, a posição do FMI ${ }^{110}$ reflete-se na "transparency of goverment accounts, the effectiveness of public resource management, and the stability and transparency of the economic and regulatory enviroment for the private sector activity”.

Em 2007, o FMI publicou o "Code of good practices on fiscal transparency” ${ }^{\prime 11}$, uma declaração de princípios iniciada no final do século passado ${ }^{112}$. $\mathrm{O}$ código de boas práticas fiscais ressalta os princípios da governança, quais sejam, o da transparência (disclousure), equidade (fairness), prestação de contas (accountability) e responsabilidade corporativa.

Tomando como base os princípios de governança que norteiam o código de boas práticas fiscais, é possível estabelecer alguns pilares para a interpretação do ordenamento pátrio em matéria de Direito Financeiro, uma vez que estão fundamentados nos mesmos valores de proteção à res publica. Assim, no que tange ao dever de transparência estabelece o código que:

1.2 There should be a clear and open legal, regulatory, and administrative framework for fiscal management.

\footnotetext{
${ }^{109}$ Muitos dos dispositivos da LRF já vinham sendo debatidos por profissionais ligados a organismos financeiros internacionais, como no seminário realizado em 1997 em Brasília, quando Teresa TerMinassian (1997), do FMI, proferiu palestra defendendo o controle abrangente da dívida pública dos governos e também de seus déficits, abordando também questões ligadas à necessidade de transparência fiscal para a credibilidade econômica. O mesmo assunto também foi tratado em artigos do Fundo Monetário Internacional, que editou um código de boas práticas fiscais.

${ }^{110}$ GOOD Governance: the IMF's role, Washington D.C., August, 1997. Disponível em: <https://www.imf.org/external/pubs/ft/exrp/govern/govern.pdf>. Acesso em: 28 out. 2009.

${ }^{111}$ INTERNATIONAL MONETARY FUND. Code of good practices on fiscal transparency, 2007. Disponível em: <http://www.imf.org/external/np/pp/2007/eng/051507c.pdf>. Acesso em: 01 nov. 2009.

${ }^{112}$ INTERNATIONAL MONETARY FUND. Code of good practices on fiscal transparency in monetary and financial policies: declaration of principles, 1999. Disponível em: <http://www.imf.org/external/np/mae/mft/code/index.htm\#goodtrans>. Acesso em: 01 nov. 2009.
} 
Este artigo do mencionado Código ${ }^{113}$ traz a exigência de que as estruturas e funções do governo devem ser claras e precisas, na medida em que as atribuições fiscais dos Poderes da República sejam definidas. Ademais, devem ser relevadas as responsabilidades para que sejam também compartilhadas entre os entes da federação.

Já com relação ao planejamento orçamentário, o código de boas práticas recomenda que:

2.1 Budget preparation should follow an established timetable and be guided by well-defined macroeconomic and fiscal policy objective.

O orçamento deve ser específico e aderir a um cronograma a fim de que seja apreciado pelo Legislativo. Deve ser realístico de modo que seja preparado e apresentado dentro de um contexto macro-econômico a médio prazo que, por sua vez, possa definir metas fiscais proporcionais à condição financeira do Estado em dado momento.

2.2 There should be clear procedures for budget execution, monitoring, and reporting.

A contabilidade pública oficial deve prover uma base instrumental confiável. Mais do que isto, o monitoramento deve acompanhar os resultados produzidos pela Administração, reportando tais controles aos órgãos competentes e especialmente à sociedade.

3.1 The public should be provided with comprehensive information on past, current, and projected fiscal activity and on major fiscal risks.

3.2 Fiscal information should be presented in a way that facilitates policy analysis and promotes accountability.

Por fim, recomenda que há que existir procedimentos de controle permanentes, inclusive o controle externo independente, em nosso ordenamento executado principalmente pelos Tribunais de Contas.

${ }^{113} \mathrm{Cf}$., ainda, INTERNATIONAL MONETARY FUND. Manual on fiscal transparency, Washington D.C., 2007. Disponível em: <http://www.imf.org/external/np/pp/2007/eng/101907m.pdf>. Acesso em: 01 nov. 2009. 
Conclui-se que a gestão financeira do Estado é tema relevante em qualquer país, pois que é um dos fatores determinantes do desenvolvimento social e econômico de uma nação. Assim, no âmbito da atividade financeira do Estado há quatro eixos importantes que serão a seguir: o planejamento orçamentário, a execução orçamentária, a responsabilidade fiscal e, por fim, o controle que será tratado em capítulo à parte.

\subsection{O Planejamento orçamentário}

O orçamento é um importante instrumento de governança republicana, pois que por meio dele, conforme ensina Régis de Oliveira (2008, p. 27), o governante planeja suas ações, "de forma a evidenciar a política econômico-financeira e o programa de trabalho do governo".

Régis de Oliveira (2008, p. 301) observa que “o orçamento não tem caráter meramente contábil”. Na realidade, o planejamento orçamentário deve servir como um instrumento de mitigação do conflito de agência, pelo fato de que possibilita ao cidadão o monitoramento prévio das ações de governo e das prioridades estabelecidas pelo governante.

Nesse sentido é a lição de Sérgio Assoni Filho (2009, p. 80), ao conceituar o orçamento como "a personificação de todo um programa ou plano de atuação governamental para um determinado período, no sentido de que a execução orçamentária expõe, objetivamente, a forma de intervenção do poder político no substrato socioeconômico estatal".

Em consonância, temos a visão de Mauro Santos Silva (2001, p. 1), para quem o orçamento público deve ser entendido, além de peça econômica e política, como

[...] uma peça de natureza legal que identifica a quantidade e a origem dos recursos financeiros disponíveis para uso do setor público governamental e aponta o destino da aplicação das disponibilidades em cada exercício financeiro, segundo programas previamente elaborados [...] uma espécie de matriz global de políticas públicas. 
Não é, pois, coincidência jurídica a posição de destaque do orçamento na Carta Constitucional. Destaca-se a lição de Ricardo Lobo Torres (2005, p. 171), para quem a Constituição de 1988 institui verdadeiramente o Estado Orçamentário, haja vista que

[...] do ponto de vista formal a Constituição Orçamentária brasileira não se esgota na seção II do cap. II do título VI, denominada "Dos Orçamentos" (arts. 165 a 169), pois abrange também as normas de controle da execução orçamentária (arts. 70 a 75), o orçamento do Poder Judiciário (art. 99) e a fiscalização orçamentária dos municípios.

Tratando-se o orçamento de evidenciação do planejamento governamental e da definição das prioridades da gestão, configurando-se em verdadeiro programa de governo $^{114}$, os instrumentos jurídicos que regulam essa atividade não podem ser interpretados seguindo-se mera análise formal-legalista. Não basta o cumprimento formal e burocrático dos dispositivos normativos que tratam do planejamento orçamentário. É preciso que o orçamento e sua execução estejam inteiramente abrangidos pelos mecanismos de governança republicana, sob pena de estarem os cidadãos alijados de seus direitos republicanos, como titulares da res publica.

Seguindo-se essa linha de raciocínio, o processo orçamentário não deve representar apenas o cumprimento de formalidades legais, com a simples remessa de um documento com previsão de receitas e despesas pelo Poder Executivo ao Poder Legislativo. Deve sim ser um processo permanente de planejamento e controle, apto a direcionar a administração pública e oferecer ao cidadão informações precisas sobre o andamento da gestão, com canais para efetiva participação na sua elaboração e também na implementação ${ }^{115}$.

\footnotetext{
${ }^{114}$ Cf. OLIVEIRA, Régis Fernandes de. op. cit., p. 317.

${ }^{115}$ José Antônio de Oliveira (OLIVEIRA, José Antônio de. Desafios do planejamento em políticas públicas: diferentes visões e práticas. Revista de Administração Pública, Rio de Janeiro, v. 40, n. 1, p. 275, mar./abr. 2006) traça o perfil de três escolas de pensamento sobre o planejamento de gastos públicos: a primeira se preocupa essencialmente com planos em sentido de "tomada de decisões políticas, reuniões de discussão, mapas detalhados, modelos matemáticos e cenários, criação de legislação e distribuição de responsabilidades", de modo que o enfoque é desenvolver planos sob ótica mecânica, isto é, com o pressuposto de que de um bom plano decorre um bom resultado. Já a segunda inclui a implementação como um elemento intrínseco. Nesse sentido, ambas as escolas deixam o cidadão e a sociedade excluídos do processo, acarretando distanciamento entre o agente e o principal. Por fim, a terceira escola e mais moderna incorpora completamente a implementação no conceito de planejamento estatal e amplia a participação social. Como consequência, há necessariamente um exame comparativo entre o abstrato em proporção aos resultados obtidos por meio de mecanismos de controle. Dentre estes, incluem-se "monitoramento, auditorias e reuniões técnicas de acompanhamento.".
} 
O processo de planejamento orçamentário obedece a um rito específico, estabelecido na Constituição Federal e em normas infraconstitucionais. Inicia-se com o governante, em seu primeiro ano de mandato, elaborando o plano plurianual ${ }^{116}$ para os quatro próximos exercícios. No plano plurianual são estabelecidos os objetivos, metas e diretrizes de cada esfera da administração pública, com a especificação das despesas de capital e outras delas decorrentes, relativas a programas de duração continuada.

Com base no plano plurianual, o Poder Executivo elabora o projeto de Lei de Diretrizes Orçamentárias (LDO) ${ }^{117}$, que compreenderá as "metas e prioridades da administração pública federal”, mas também das esferas estadual e municipal, incluindo as despesas de capital para o exercício financeiro subsequente. Além disso, a LDO orientará a elaboração da Lei Orçamentária Anual (LOA). Tal documento (LDO) disporá também sobre as alterações na legislação tributária e estabelecerá a política de aplicação das agências financeiras oficiais de fomento.

A Lei Orçamentária Anual $^{118}$, por sua vez, compreende o orçamento fiscal, o orçamento de investimento das empresas (onde a administração pública detenha a maioria do capital social com direito a voto) e o orçamento da seguridade social. A LOA conterá as receitas e despesas discriminadas de forma a evidenciar a política econômicofinanceira e o programa de trabalho do governo.

Deve o administrador público, portanto, considerar o orçamento não só como uma mera formalidade a ser cumprida, mas sim como um instrumento de governança republicana, onde o governante estabelece diretrizes e prioridades na alocação dos recursos públicos e deve ser cobrado pelos resultados alcançados com a sua execução. Essa nova concepção de orçamento coaduna-se com a implementação da gestão por resultados ${ }^{119}$. Conforme Izabela Moreira Corrêa (2007, p. 498),

[...] a gestão pública por resultados foi, assim, desenvolvida como uma estratégia que tem início no momento do planejamento estratégico e vai até o processo de feedback das políticas públicas, podendo ser considerada uma prática de boa governança e desenvolvimento

\footnotetext{
${ }^{116}$ Constituição Federal, artigo 165 , parágrafo $1^{\circ}$.

${ }^{117}$ Constituição Federal, artigo 165, parágrafo $2^{\circ}$.

${ }^{118}$ Constituição Federal, artigo 165 , parágrafo $5^{\circ}$, inciso I.

${ }^{119}$ Cf. Gilmar Ribeiro de Mello et al. (MELLO, Gilmar Ribeiro de; BITENCOURT, Ana Carolina Esteves dos Passos; MAGALHÃES, Arthur Olivare de; SLOMSKI, Valmor. Nível de disclosure do orçamento público federal brasileiro. Revista Enfoque Reflexão Contábil, v. 26, n. 1, p. 43, jan./abr. 2007), que explica que "Em 1999, o orçamento brasileiro passou por reformulação, buscando a modernização dos processos de planejamento e orçamento, visando a administração gerencial voltada para resultados".
} 
institucional, respeitando princípios da distribuição eficiente de recursos públicos e accountability.

Tem-se, assim, que o ciclo orçamentário só se esgota com a completa implementação do programa governamental e a avaliação dos seus resultados.

A partir da premissa de que o orçamento é um instrumento da governança republicana, capaz de atenuar os conflitos de agência entre o cidadão e o agente público, cabe uma reflexão sobre suas consequências lógico-jurídicas. A interpretação dos dispositivos contidos na Constituição Federal, na Lei 4.320/64 e na Lei de Responsabilidade Fiscal deverá ser empreendida de maneira coesa e sistemática, sempre considerando que o planejamento orçamentário espelha as diretrizes governamentais, as quais deverão ser objeto de monitoramento e avaliação da sociedade e das instituições competentes. No entender de Régis de Oliveira (2008, p. 375) "deve-se controlar não só regularidade da entrada e da saída de recursos, como também o comportamento dos agentes e o cumprimento dos objetivos delineados pela Administração Pública”.

Para isso, a classificação didática oferecida por Mauro Santos Silva (2001, p. 3) é útil quando o objetivo é interpretar os dispositivos sob a perspectiva do cumprimento de diretrizes e metas. Segundo tal autor, a execução do orçamento pode ser dividida em i) orçamentária, "comprometimento da dotação disponível"; ii) física, "realização de obra ou serviço ou aquisição do bem previsto na lei orçamentária" e iii) financeira, pagamento de despesa comprometida e líquida. Dessa forma, segundo o autor (2001, p. 3), é possível definir o objeto do cumprimento de diretrizes e metas, a saber: O controle das ações governamentais relativas à execução orçamentária,
física e financeira, envolve o conjunto de procedimentos executados pela
burocracia estatal e ou pela sociedade civil, orientados à obtenção de
informações que permitam o conhecimento dos atos praticados pelo
Poder Público em relação à forma, ao conteúdo e às consequências
produzidas. O controle ex exercido ao longo do ciclo e o seu produto final
é matéria-prima importante para a avaliação do desempenho da gestão
governamental.

Destarte, a passagem do planejamento à efetiva execução não tem somente como fim evitar desvios de comportamento, mas também promove um duplo feedback. Em primeiro lugar, promove um arcabouço de conhecimento comparativo para 
futuras alterações no próprio planejamento e, além disso, funciona como mecanismo de avaliação da eficácia dos governantes, o que, por sua vez, aproxima a sociedade do governo, promovendo a inclusão política do cidadão na gestão pública. Em reforço, Fabiana Rocha e Ana Carolina Giuberti (2007, p. 482) alertam para constatação resultante de pesquisa científica de que países com maior transparência e hierarquia na execução orçamentária produzem melhores resultados em termos de gasto público. Assim, uma melhora na condução da peça orçamentária pode implicar em melhor comportamento fiscal agregado.

Neste momento, fica reforçada a necessidade de integração das normas relativas ao planejamento orçamentário à governança republicana, tendo, esta, a função de servir como vetor de interpretação. Para tal, a moldura constitucional e legal do sistema de proteção à res publica envolve os princípios da Administração Pública e as normas de Direito Financeiro.

No que tange ao monitoramento do planejamento orçamentário e sua execução, é fundamental que a atividade de controle interno também funcione sob a perspectiva da governança republicana. Para tal, a norma constitucional que direciona o gestor público está prevista no artigo $74^{120}$ e seu inciso I, que estabelece, in verbis:

Art. 74 - Os Poderes Legislativo, Executivo e Judiciário manterão, de forma integrada, sistema de controle interno com a finalidade de:

I - avaliar o cumprimento das metas previstas no plano plurianual, a execução dos programas de governo e dos orçamentos da União;

Dentre os dispositivos infraconstitucionais sobre o tema, destaca-se o art. 75 da Lei 4.320/64, cujo teor é o seguinte:

Art. 75. O controle da execução orçamentária compreenderá:

I - a legalidade dos atos de que resultem a arrecadação da receita ou a realização da despesa, o nascimento ou a extinção de direitos e obrigações;

II - a fidelidade funcional dos agentes da administração, responsáveis por bens e valores públicos;

\footnotetext{
${ }^{120}$ Tanto José Afonso da Silva (SILVA, José Afonso da. Curso de direito constitucional positivo. 31. ed. São Paulo: Ed. Revista dos Tribunais, 2008. p. 471), como Ricardo Lobo Torres (TORRES, Ricardo Lobo. Curso de direito financeiro e tributário. 12. ed. São Paulo: Renovar, 2005. p. 199) entendem que tal dispositivo está mal situado na $\mathrm{CF} / 88$, tendo em vista tratar de controle interno em meio a dispositivos relativos ao controle externo.
} 
III - o cumprimento do programa de trabalho expresso em termos monetários e em termos de realização de obras e prestação de serviços.

Além disso, a Lei Complementar nº101/2000, Lei de Responsabilidade Fiscal, ao estabelecer normas para a gestão fiscal responsável, no seu capítulo IX, sobre transparência, controle e fiscalização, determina que será assegurada transparência por meio de incentivo a participação popular no processo de planejamento governamental.

Quanto ao art. 75 da Lei de Orçamentos, Machado Júnior e Heraldo da Costa Reis (2003, p. 165) ${ }^{121}$ trazem um rol exemplificativo de eventuais irregularidades na gestão financeira. Não obstante a relativa clareza e fácil percepção dos desvios contra o "dever de boa administração", há vários desafios à aplicabilidade da norma. Uma delas, apontada por Flávio Toledo Jr. e Sérgio C. Rossi (2005), é a dificuldade que os servidores efetivos de pequenos municípios, que representam $93 \%$ da Federação, têm para desempenhar o controle interno, pois denunciando irregularidades ficarão eles em situação delicada junto ao denunciado; sendo que este, na maioria das vezes, é agente político com relativa influência na comunidade. Tem-se, pois, pelo exemplo acima, que as estruturas de governança republicana, muito embora positivadas no ordenamento jurídico, não são necessariamente colocadas em prática completamente, frustrando-se, portanto, ao menos uma das condições mínimas de transparência, accountability, legalidade, ética, eficiência e eficácia.

Mauro Santos Silva (2001, p. 5) sugere parâmetros para dinamizar o fluxo informacional na atividade de controle, podendo ser aplicada ao planejamento orçamentário, a saber:

- clareza na definição dos procedimentos associados a execução das ações previstas para a política observada;

- disponibilidade de objetivos e metas bem definidos para a política a ser focada pelo controle;

- critérios para avaliação dos resultados mensurados;

\footnotetext{
${ }^{121}$ Os autores apontam (TOLEDO JR., Flávio Correa; ROSSI, Sérgio Ciquera. A Lei 4.320 no contexto da Lei de Responsabilidade Fiscal. 31. ed. São Paulo: NDJ, 2003. p. 165) possíveis desvios: "Se a Administração deixar de fazer o lançamento de receita contra um contribuinte (...) Se a Administração empenhar despesas sem saldo suficiente na dotação ou deixar de empenhar previamente uma despesa (...) De mesma forma, se deixa de providenciar o recebimento de um crédito legal inscrito (...) Se deixa de cumprir os serviços da dívida pública, estará incidindo em falta relativa ao passivo ou às obrigações legalmente constituídas".
} 
- dinâmica ágil e eficiente de processamento e distribuição das informações aos atores interessados e que exercem influência nos processos decisórios; e

- decisões ágeis, de forma a permitir o ajustamento das ações e minimizar os custos das imperfeições observadas.

A interpretação dos dispositivos constitucionais e infraconstitucionais acima citados, combinados com o Princípio da Eficiência previsto no artigo 37 da Constituição Federal, leva inexoravelmente ao controle de eficácia, eficiência e economicidade de todo o ciclo de planejamento orçamentário. De fato, essas dimensões devem estar abrangidas na avaliação de resultados dos programas governamentais e, dessa forma, constituir vetores para a interpretação das normais constitucionais e infraconstitucionais, envolvendo todas as esferas e níveis da gestão pública, desde a alta direção, até os responsáveis pela implementação das políticas públicas ${ }^{122}$. O objetivo, neste caso, é o monitoramento sobre o cumprimento do planejamento, ou seja, verificar, segundo Mauro Santos Silva (2001, p. 5),

[...] se o poder público está executando ações conforme as escolhas públicas manifestadas nos fóruns competentes e materializada na peça orçamentária aprovada pelo Legislativo e promulgada pelo Executivo. Como objetivos derivados do elemento central supramencionado, estão a busca da constatação de que as ações não só estão sendo realizadas conforme as escolhas pública, mas, também, estão sendo conduzidas conforme os preceitos de legalidade, legitimidade, eficiência, eficácia e efetividade (grifo nosso).

E completa Mauro Santos Silva (2001, p. 5), para quem

O controle sobre as ações realizadas pelo setor público governamental é uma função administrativa que envolve um conjunto de procedimentos adotados com o objetivo de acompanhar e identificar se as ações relativas ao ciclo das políticas públicas planejadas são executadas conforme o interesse dos atores sociais interessados e se estão produzindo os resultados esperados, tudo isto dentro do quadro de legalidade definido pelo conjunto de regras em vigor (grifo nosso).

\footnotetext{
${ }^{122}$ Conforme Izabela Moreira Corrêa (CORRÊA, Izabela Moreira. Planejamento estratégico e gestão pública por resultados no processo de reforma administrativa do estado de Minas Gerais. Revista de Administração Pública, Rio de Janeiro, v. 41, n. 3, p. 500, maio/jun. 2007), "Dado o foco no cumprimento de ações definidas, é necessária maior vinculação entre a alta direção e suas "unidades" operativas, para que sejam definidos as responsabilidades e compromissos mutuamente assumidos. Com o objetivo de fortalecer esse vínculo, acordos que estipulam os resultados a serem alcançados são, geralmente, articulados entre as duas partes. Nesse tipo de acordo, as unidades operativas se comprometem a cumprir com as metas previamente estabelecidas, enquanto a alta direção fornece incentivos que favorecem o alcance das metas.”.
} 
Importante aspecto relativo ao planejamento orçamentário diz respeito à participação da sociedade no processo, tema que é objeto de experiências práticas em vários municípios brasileiros, além de estudos acadêmicos.

Em regra, no Brasil tradicionalmente o processo de planejamento orçamentário tem como característica a centralização das decisões, alienando a sociedade das definições e até, em alguns casos, afastando-se das próprias diretrizes estabelecidas no plano plurianual ou no plano de governo proposto à época das eleições. Trata-se, lamentavelmente, de situação comum, em que os interesses da sociedade ficam divorciados das ações governamentais, evidenciando os conflitos de agência entre cidadão e agente público. O planejamento padece, assim, de legitimidade, pois a implementação do planejamento orçamentário sofre com a alienação de seus beneficiários ao distanciá-los desnecessariamente do cotidiano da gestão pública.

Sérgio Assoni Filho (2009, p. 80), discorrendo sobre a relevância do planejamento orçamentário, explica que

A atividade financeira da administração pública representa a procura pelos recursos indispensáveis ao atendimento dos interesses públicos, bem como a sua administração, a fim de que os meios materiais obtidos sejam empregados da melhor maneira possível neste intento. Tal atividade tem como principal espelho o orçamento público, uma vez que, longe de ser uma mera peça de natureza contábil, em que podem ser visualizadas as receitas previstas e as despesas autorizadas, as leis orçamentárias também se apresentam como a personificação de todo um programa ou plano de atuação governamental para um determinado período, no sentido de que a execução orçamentária expõe, objetivamente, a forma de intervenção do poder político no substrato socioeconômico estatal, em última análise, com o escopo de saciar, de fato, aquelas necessidades.

Ao afastar a sociedade das definições do orçamento, atenta-se, principalmente, ao risco de despolitização do orçamento público, tornando-o, como já dito, ato burocrático ou mero cumprimento de obrigação legal.

Uma das respostas encontradas para o divórcio entre a sociedade e o planejamento é o orçamento participativo ${ }^{123}$. Trata-se de mecanismo que expande a participação dos cidadãos, aproximando-os das decisões relativas aos seus interesses

\footnotetext{
${ }^{123}$ Para Sérgio Assoni Filho (ASSONI FILHO, Sérgio. op. cit., p. 154), "Os cidadãos devem ter à sua disposição canais apropriados à manifestação de suas opiniões durante os processos de elaboração e execução dos orçamentos públicos, o que está em perfeita congruência com o ordenamento brasileiro, que institucionalizou o controle social orçamentário, democratizando tanto a destinação das despesas públicas quanto a fiscalização da atividade financeira estatal."
} 
comunitários. Incentiva-se não apenas a definição das prioridades, mas também o acompanhamento de sua execução, até a conclusão do investimento ou política pública.

Sérgio Assoni Filho (2009, p. 81) defende que a participação popular dá publicidade e transparência à atividade financeira estatal. Dessa forma, configura-se como instrumento de governança republicana. A efetiva participação da sociedade incentiva a fiscalização do gasto público, reduzindo-se as possibilidades de malversação de recursos públicos.

Não está no escopo deste trabalho a discussão acerca do processo de orçamento participativo, mas tão somente a importância da participação social como instrumento de governança republicana. Assim, embora não exista fórmula única de participação social, nem tampouco a positivação normativa dessa prática, é certo que a abertura do processo de planejamento orçamentário para participação nas decisões a respeito das definições de prioridades e dos investimentos pode ser denominado de orçamento participativo $^{124}$. Conforme sustenta Sérgio Assoni Filho(2009. p. 154),

Os cidadãos devem ter à sua disposição canais apropriados à manifestação de suas opiniões durante os processos de elaboração e execução dos orçamentos públicos, o que está em perfeita congruência com o ordenamento brasileiro, que institucionalizou o controle social orçamentário, democratizando tanto a destinação das despesas públicas quanto a fiscalização da atividade financeira estatal.

Régis de Oliveira (2008, p. 359) sintetiza os caracteres do orçamento participativo:

- busca a decisão descentralizada;

- cria conselhos populares, o que enseja opinião pública independente;

\footnotetext{
${ }^{124}$ Cf. Pires (PIRES, Roberto R. Orçamento participativo e o planejamento municipal: uma análise neoinstitucional a partir do caso da Prefeitura de Belo Horizonte. Monografia, EG/FJP, Belo Horizonte, 2001. p. 17) e Caldas (CALDAS, Eduardo de Lima. Finanças públicas e orçamento participativo: a experiência municipal brasileira. In: CONGRESO INTERNACIONAL DEL CLAD SOBRE LA REFORMA DEL ESTADO Y DE LA ADMINISTRACIÓN PÚBLICA, 5., Santo Domingo, 24 a 27 Oct. 2000. p. 1), que relatam que "O orçamento participativo é uma prática inovadora iniciada em Vila Velha (ES), em meados dos anos 70, na qual o município era dividido em regiões que recebia pontos de acordo com a população e com a carência regional. Esses pontos, posteriormente eram convertidos em recursos orçamentários. Posteriormente (já no final da década de 80 e início da década de 90) essa prática foi adotada em diversos municípios brasileiros, dentre os quais: Santos (SP), Ribeirão Preto (SP), São José dos Campos (SP), Betim (MG) e Belo Horizonte (MG), dentre outros. Porém, a experiência de Porto Alegre (RS) é a mais bemsucedida e vigora até os dias atuais (ou seja, manteve-se por três gestões administrativas).
} 
- faz com que o cidadão desloque seu centro de atenção para os problemas locais;

- gera consciência de participação;

- dá nascimento a dois focos de poder democrático, um, pelo voto; outro pelas instituições diretas de participação;

- objetiva criar condições para aprovação do orçamento e despertar participação;

- enseja a instauração de um processo aberto de discussão;

- necessita de auto-regulação interna, para disciplina do processo decisório e para que dele não nasça viciado.

É possível concluir que a abertura do processo de planejamento orçamentário à sociedade desloca qualitativamente a participação política do cidadão, que passa de eleitor a partícipe na gestão governamental, estabelecendo protagonismo e compromisso popular com as definições aprovadas ${ }^{125}$. Para Domingues Filho (2004, p. 200-201),

O ideal que torna o orçamento participativo uma peça institucional importante para o desenvolvimento da democracia diz respeito à possibilidade dessa instituição política combinar participação direta com o modelo clássico de democracia (eleição, sufrágio universal, alternância no poder, liberdade de divergir, igualdade de voto dos cidadãos). $\mathrm{O}$ orçamento participativo é considerado, pelos seus entusiastas (inspirados por Jürgen Habermas), como um fórum complementar de participação. Este espaço público de participação direta pode fortalecer a democracia, pois eleva os cidadãos a um grau mais elevado de exercício dos direitos contidos na dimensão de sua cidadania. O que é esperado, como frutos democráticos, do Orçamento Participativo, realmente, é relevante para o desenvolvimento da democracia, em termos de maior eficiência do Estado na realização de suas funções públicas (grifo nosso).

De outro lado, nas palavras de Sérgio Assoni Filho (2009, p. 153),

Os gastos governamentais autorizados no orçamento público servirão como verdadeiros instrumentos a serviço da transparência fiscal, à medida que houver o fomento a um contínuo controle social da atividade financeira do Estado, propiciando que qualquer cidadão verifique se as

\footnotetext{
${ }^{125}$ Nesse sentido, Eduardo Caldas (2000, p. 2) afirma que “o orçamento participativo supera a prática consagrada de elaboração orçamentária. No entanto, apesar do nome, observa-se que não é apenas uma prática ou política específica de planejamento das finanças, mas uma mudança de postura frente à gestão. Também não se trata de um simples mecanismo que contempla a participação popular num determinado assunto, mas exige a atuação e participação da esfera pública durante toda a gestão".
} 
suas preferências, expostas nas discussões e deliberações referentes à aprovação das leis orçamentárias municipais, correspondem ou não aos investimentos efetivamente realizados pelos gestores da coisa pública.

De outro lado, não resta dúvida de que a vinculação da administração pública à peça orçamentária definida com a participação social é muito maior, uma vez que se trata de acordo de corresponsabilidade entre o administrando e os administrados. Muito embora não haja norma que obrigue o Poder Público ao estrito cumprimento do orçamento elaborado com a participação da sociedade, sua modificação sem motivo justo causaria enorme desgaste político, tendo em vista os compromissos que são assumidos durante o processo de definição das prioridades ${ }^{126}$.

A despeito da possibilidade de implantação de mecanismos de participação popular no processo de planejamento orçamentário da União e dos Estados, a prática é mais comum nos municípios, especialmente pela proximidade do cidadão com suas necessidades e demandas locais. De fato, a possibilidade da participação popular garantida pela Constituição Federal é resguardada pela condição ímpar do município no desenho federativo brasileiro. Ademais, regulamentação é oferecida pelo Estatuto da Cidade a fim de agregar eficácia plena e aplicabilidade direta e imediata ${ }^{127}$ das normas constitucionais. Basta tão somente previsão no Plano Diretor Municipal para se configure fator de eficácia e vinculação normativa. A título de exemplo, o Plano Diretor do Município de São Paulo possui previsão de participação popular direta em várias instâncias de planejamento, inclusive o orçamentário ${ }^{128}$.

Um dos aspectos mais importantes para a abertura do processo de planejamento orçamentário à sociedade é a necessidade de forte atuação governamental, que de forma técnica pode traduzir as demandas sociais em providências factíveis. $\mathrm{O}$

\footnotetext{
${ }^{126}$ Cf. FRANZESE, Cibele; PEDROTI, Paula Maciel. Limites e possibilidades do orçamento participativo: para além da retórica. Revista de Administração Pública, Rio de Janeiro, v. 39, n. 2, p. 222, mar./abr. 2005.

${ }^{127}$ Cf. SILVA, José Afonso da. Aplicabilidade das normas constitucionais, cit., p. 101.

${ }^{128}$ Art. 279 - É assegurada a participação direta da população em todas as fases do processo de gestão democrática da Política Urbana da Cidade mediante as seguintes instâncias de participação:

I - Conferência Municipal de Desenvolvimento Urbano;

II - Assembléias Regionais de Política Urbana;

III - Conselho Municipal de Política Urbana;

IV - audiências públicas;

$V$ - iniciativa popular de projetos de lei, de planos, programas e projetos de desenvolvimento urbano;

VI - conselhos reconhecidos pelo Poder Executivo Municipal;

VII - assembléias e reuniões de elaboração do Orçamento Municipal;

VIII - programas e projetos com gestão popular;

IX - Comissão de Legislação Participativa da Câmara Municipal de São Paulo.
} 
diálogo entre governo e sociedade só será qualificado com a presença do Estado, possibilitando que as demandas sejam instrumentadas pela ação estatal ${ }^{129}$.

A aplicação dos instrumentos de governança republicana no planejamento orçamentário deve envolver todo o ciclo da despesa pública, desde sua orçamentação até seu efetivo dispêndio, exigindo avaliação dos resultados alcançados com a efetivação dessa despesa. Assim, fundamental analisar o processo de avaliação da eficiência do gasto público, bem como os mecanismos de monitoramento dos resultados alcançados com a alocação dos recursos públicos.

\subsection{Eficiência do gasto público e avaliação de resultados}

Após cruzar o planejamento estratégico, deve-se atuar sobre sua continuação lógica, o controle de eficiência dos serviços públicos prestados e investimentos realizados. Aqui não se trata do controle de legalidade ou de regularidade formal. O foco analítico volta-se essencialmente aos desvios das funções típicas do aparelho estatal bem como à maximização da eficiência e eficácia destas ações, no que se pode denominar de auditoria de performance.

Os recursos públicos, amealhados mediante ação tributante do poder estatal, são sempre escassos e os critérios para a sua alocação são determinantes para o desenvolvimento econômico e social. Recursos bem aplicados e geridos são, normalmente, sinônimo de desenvolvimento e bem-estar social ${ }^{130}$.

O controle fiscal não é mero conjunto de checks and balances das funções públicas, ou mesmo uma comparação posterior de uma previsão anterior. Ao contrário, o controle fiscal, segundo Humberto Petrei (1998, p. 15), contém quatro pilares fundamentais das atividades estatais:

- mecanismos institucionais que garantam o mínimo possível de desvio entre preferências individuais e ações estatais;

- atividade de controle do Poder Legislativo sobre as atividades do Executivo;

\footnotetext{
${ }^{129}$ Nessa linha, Cibele Franzeze e Paula Pedroti (FRANZESE, Cibele; PEDROTI, Paula Maciel. op. cit., p. 227) e Denis A. Rezende e Clovis Ultramari (2007, p. 267), que entendem que o processo de planejamento participativo deve contar com equipe multidisciplinar para apoio técnico.

${ }^{130}$ Cf. FONSECA, Josefa Pereira da. Controle externo do gasto público sob a ótica da economicidade. 1992. Dissertação (Mestrado) - EAESP/FGV, 1992. p. 17.
} 
- sistema confiável de informações, segundo os quais os agentes políticos mensuram a eficiência sobre a burocracia sob seu trato;

- estímulos para que os indivíduos sejam induzidos a dedicar-se à res publica.

Para tanto, não é mais suficiente que os critérios meramente jurídicos (legalidade) ou procedimentais (formalidade) sejam os únicos ou preponderantes no controle da administração. Nessa linha, segue-se a divisão proposta por Antônio Magalhães Ribeiro (2004, p. 93), segundo o qual os controles oficiais resguardam os atos e fatos administrativos de desvios quanto i) ao planejamento, ii) às condutas probas e, além disso, iii) incumbem-se de adotar as medidas pertinentes para ambos os casos.

As evoluções dos sistemas de controle e monitoramento da administração pública podem ser consideradas como conquistas da sociedade pelos direitos republicanos, assim como as conquistas de outros direitos fundamentais, como os direitos civis e sociais. Régis de Oliveira (2008, p. 393) reforça este raciocínio afirmando que "Muitas foram as lutas para todos aqueles que tocassem no dinheiro público ficassem obrigados a prestar contas."

\section{A International Organization of Supreme Audit Institutions (INTOSAI)} explicita que o próprio conceito e origem da auditoria tangenciam a administração financeira pública, na medida em que representa um elemento de confiança entre administração e administrados ${ }^{131}$.

A gestão pública conta com princípios e respectivos alcances que ultrapassaram o limiar da legalidade, principalmente na atual ordem constitucional. Assim, não há razão para excluir da atividade de controle os aspectos relacionados aos resultados alcançados pela gestão pública ${ }^{132}$, sob o argumento de que a legalidade deve ser a fonte

\footnotetext{
${ }^{131}$ INTERNATIONAL ORGANIZATION OF SUPREME AUDIT INSTITUTIONS (INTOSAI). Lima Declaration of Guidelines on Auditing Precepts. Viena, 2009. p. I-10.: “Audit is not an end in itself but an indispensable part of regulatory system whose aim is to reveal deviations from accepted standards and violations of the principles of legality, efficiency, effectiveness and economy of financial management early enough to make it possible to corrective action in individual cases, to make those accountable accept responsibility, to obtain compensation, or to take steps to prevent - or at least render more difficult - such breaches".

${ }^{132}$ Cf. Luís Henrique Paiva (PAIVA, Luís Henrique. A qualidade do gasto público e a avaliação das políticas sociais: o orçamento do Ministério do Trabalho no período 2000-2006. Revista do Serviço Público, Brasília, v. 57, n. 3, p. 340, jul./set. 2006), que argumenta que "Como, além de expandir fortemente seus gastos ao longo dos últimos 15 anos, o governo central também passou a gerar robustos superávits primários desde 1999, com o objetivo de controlar o aumento da relação dívida pública/PIB, a carga tributária chegou a aproximadamente $37 \%$ do PIB em 2005. Como não poderia deixar de ser, a imposição de uma carga como essa, em um país em desenvolvimento, certamente é responsável pelo maior questionamento da qualidade dos gastos públicos.
} 
preponderante, pois é onde "repousam a essência e fronteira da função administrativa"133.

Em síntese, a maior eficiência no gasto público é pressuposto para que sejam alcançados melhores níveis na alocação de políticas públicas, maior crescimento econômico e aumento da qualidade de vida em geral $^{134}$.

É imperioso, pois, o devido controle sobre as despesas públicas, especialmente visando a parâmetros de boa gestão financeira, a saber: i) desperdícios, ii) abuso administrativo (incluindo a corrupção), iii) desordem administrativa, iv) erros, v) fraudes e vi) outras irregularidades. Nesse sentido, Antônio Magalhães Ribeiro (2004, p. 93) define controle interno como sendo um conjunto orgânico de "normas e procedimentos instituídos pelas organizações com vistas na proteção de seu patrimônio e na elaboração de dados confiáveis em busca da eficácia operacional”. Por outro lado, a INTOSAI (2004, p. 13) o define, em maior harmonia ao objeto deste estudo, como "an integral process effected by an entity's management and personnel and is designed to address risks and to provide reasonable assurance that in pursuit of the entity's mission”.

A transposição de um patamar de controle formalístico e legal para outro em que tão importante quanto a legalidade é a proteção à res publica, ou seja, a tutela dos recursos financeiros em prol do interesse público, demanda a implantação de novos instrumentos gerenciais.

A implementação de uma gestão pública comprometida com a governança republicana requer a adoção de uma série de medidas administrativas transformadoras, envolvendo praticamente todas as dimensões da administração, tais como a incorporação de novas técnicas de gestão, o estabelecimento de metas de desempenho mensuráveis e o comprometimento dos envolvidos, desde funcionários, servidores, prestadores de serviços, até o próprio cidadão.

O primeiro passo para essa mudança de padrão qualitativo na gestão pública passa por uma grande revolução nos seus paradigmas. Uma dessas transformações necessárias é a mudança de enfoque em relação aos resultados produzidos pelo Estado, ou

\footnotetext{
${ }^{133}$ Cf. JARDIM, Eduardo Ferreira. Manual de direito financeiro e tributário. 2. ed. São Paulo: Saraiva, 1994. p. 65.

${ }^{134}$ Cf. Marcos Mendes (MENDES, Gilmar Ferreira; COELHO, Inocêncio Mártires; BRANCO, Paulo Gustavo Gonet. Curso de direito constitucional. 2. ed. São Paulo: Saraiva, 2008).
} 
em outras palavras, fazer com que o foco da atuação estatal seja a "gestão pública por resultados"135.

As demandas sociais avolumam-se a cada dia e o papel do Estado como provedor de serviços públicos acumula-se à sua importância como regulador e até fomentador do desenvolvimento econômico. Face a esses papéis do Estado, cujo desempenho deve necessariamente redundar em atendimento às demandas da população e efetivo desenvolvimento econômico e social, a gestão pública deve focar-se nos resultados, sendo por eles transparentemente avaliada e controlada. Nesse cenário, o gestor público será cobrado e responsabilizado pela performance, tendo como premissa a aplicação eficiente dos recursos públicos, atendendo às demandas da sociedade com rapidez e qualidade, dentro do respeito aos princípios que integram a governança republicana e que compõem o sistema de garantias aos direitos republicanos, em especial a publicidade, a moralidade, a legalidade, a prestação de contas e a responsabilização do agente público.

Foco nos resultado pressupõe a utilização de sistema de avaliação de desempenho, que normalmente são desenvolvidos com a aplicação de indicadores de desempenho gerencial, que além de medir o alcance das metas, pode servir como ferramenta de gestão e correção de $\operatorname{rumos}^{136}$.

A mensuração de resultados na administração pública é muito mais complexa do que na gestão privada. De fato, nas empresas o monitoramento de resultados limita-se quase que exclusivamente aos aspectos econômicos e financeiros. Na gestão pública, nem sempre é possível estabelecer critérios objetivos e mensuráveis para avaliação. Porém, para o cidadão é tão importante medir os gastos quanto medir a qualidade dos serviços prestados. Daí a importância da adoção de indicadores que possam avaliar quantitativa e qualitativamente os serviços públicos prestados pelo Estado. Para Regina Cardoso (1999, p. 13),

Nesse contexto, a adoção de um sistema de indicadores de gestão, que avalie permanentemente, a eficiência, a eficácia e a qualidade dos serviços prestados à comunidade tem um potencial enorme como ferramenta para melhorar a gestão pública.

\footnotetext{
${ }^{135}$ Cf. TROSA, Sylvie. Gestão pública por resultados: quando o Estado se compromete. Tradução Maria Luíza de Carvalho. Rio de Janeiro: Revan; Brasília: ENAP, 2001.

${ }^{136}$ Cf. CORRÊA, Izabela Moreira. op. cit., p. 498.
} 
Além da utilização de indicadores específicos, desenvolvidos para cada política pública implementada, a avaliação de qualidade no gasto público deve, pois, passar necessariamente pela adoção de outros instrumentos de controle e monitoramento que utilizem tecnologia de informação e técnicas contábeis.

Embora as modernas técnicas contábeis e de gestão pública disponham de vários instrumentos de controle gerencial, o método de "apuração do resultado econômico", apresentado por Valmor Slomski (2005, p. 95-107) serve de subsídio para a reflexão sobre a aplicação de novas ferramentas de avaliação da gestão pública.

A apuração do resultado econômico consiste basicamente na comparação entre os custos incorridos na prestação de um determinado serviço público e a renda econômica, consistente no menor preço de mercado para a contratação daquele mesmo serviço ${ }^{137}$. Assim, no exemplo apresentado pelo próprio autor (2005, p. 105), a receita econômica produzida por determinada escola pública seria igual à multiplicação do número de alunos pelo custo de oportunidade ${ }^{138}$. O resultado econômico, então, seria a diferença entre a receita econômica e o total dos custos incorridos para a operação da escola pública.

A comparabilidade gerada pelo cálculo periódico do resultado econômico certamente traria subsídios para o aprimoramento da gestão dos serviços públicos prestados.

O resultado econômico é apenas um exemplo da aplicação de novas ferramentas de monitoramento e avaliação da administração pública. Em verdade, no Brasil há déficit de incentivos à eficiência. Conforme Marcos Mendes (2008, p. 13), existem vários motivos para que a busca pela eficiência no gasto público seja obstada ${ }^{139}, \mathrm{o}$

\footnotetext{
${ }^{137}$ Cf. SLOMSKI, Valmor; CAMARGO, Guilherme Bueno de; AMARAL FILHO, Antônio Carlos Cintra do. Apuração do resultado econômico da Procuradoria Geral do Município de São Paulo. In: ENCONTRO DA ANPAD, 32., 2008. Anais... $\quad$ Disponível em: $<$ http://www.anpad.org.br/evento.php?cod_evento_edicao=38>. Nesse trabalho os autores aplicam o método da apuração do resultado econômico na Procuradoria Geral do Município de São Paulo.

${ }^{138}$ Menor preço de mercado para as mensalidades escolares, considerando-se as características e qualidade da escola em questão.

${ }^{139}$ a) A fonte de recursos e o interesse objetivo do servidor ou gestor público não são congruentes. Os recursos não têm a devida diligência em seu gasto já que o agente não os pagará com o próprio bolso; b) Há pouco investimento em inovação institucional. Não existem planos de carreira que recompensem inovações contributivas; c) A competição só ocorre anteriormente ao exercício da função (concurso), e não durante em virtude da estabilidade e d) Atuação monopolista do Estado em diversos setores (infraestrutura urbana, policiamento, controle de poluição, sistema judiciário). Não há, portanto, pressão por eficiência inter agentes para apresentarem melhores serviços.
} 
que demonstra que a estrutura da administração pública, em regra, não propicia a busca pela eficiência e pela qualidade. Basta lembrar que, ao contrário da administração privada, não há no setor público cultura para a gestão de custos.

Muito embora o artigo 50, parágrafo $3^{\circ}$, da LRF, estabeleça a obrigatoriedade para a manutenção de sistema integrado de custos que permita a avaliação da gestão orçamentária, financeira e patrimonial, boa parte das iniciativas não cumpre o dispositivo legal ${ }^{140}$ na sua integralidade, ou seja, como uma ferramenta de governança republicana.

Como bem observam Cezar Mauss e Marcos Antônio de Souza (2008, p. 2), "mesmo com a legislação direcionando para a obrigação da utilização das informações de custos na administração pública brasileira, isso não tem ocorrido”.

A despeito da defasagem entre o setor privado e o setor público na avaliação e monitoramento da gestão, não se pode mais olvidar em relação a esse aspecto quando se trata da administração dos recursos públicos. O desenvolvimento de novos mecanismos para acompanhamento da gestão financeira que permitam avaliar a eficiência, a eficácia, a economicidade são uma imposição do regime republicano e democrático que vige no país ${ }^{141}$.

Ademais, a ineficiência nos gastos facilita a atuação ilícita de alguns agentes públicos, ocasionando comportamentos desviantes e corrupção ${ }^{142}$. Tal constatação solidifica o entendimento pelo qual a controladoria não deve ter papel passivo. Sua função ultrapassa o limite formal da contabilidade pública e deve possibilitar o aprimoramento permanente da Administração Pública contemporânea. Contudo, o controle interno em si não é garantia para atendimento dos objetivos públicos ${ }^{143}$, uma vez que nenhum sistema

\footnotetext{
${ }^{140}$ Além da LRF, a Lei 4.320/64 (art. 99) e o Decreto-lei 200/67 também dispõem sobre a gestão de custos.

${ }^{141}$ Cf. Cezar Mauss e Marcos Antônio de Souza (MAUSS, Cezar Volnei; SOUZA, Marco Antônio de. Gestão de custos aplicada ao setor público: modelo para mensuração e análise da eficiência e eficácia governamental. São Paulo: Atlas, 2008), que tratam de sistemática de gestão de custos para o setor público brasileiro.

${ }^{142}$ Régis de Oliveira (OLIVEIRA, Régis Fernandes de. op. cit., p. 239) apresenta com muita propriedade alguns exemplos de corrupção.

${ }^{143}$ Sobre o tema, a advertência da INTOSAI (INTERNATIONAL ORGANIZATION OF SUPREME AUDIT INSTITUTIONS (INTOSAI). Guidelines for internal control standards for the public sector. Bruxelas: Internal Control Standards Committee, 2004. p. 16) de que "The benefits of controls must be consequently considered in relation to their costs. Maintaining an internal system that eliminates the risks of loss is not realistic and would probably cost more than is warranted by benefit derived. In determining whether a particular control should be established, the likelihood of risk occurring and the potential effect on the entity are considered along with the related costs of establishing a new control".
} 
pode garantir inexistência total de desvios. Além disso, os mecanismos de controle têm custos para sua implantação e execução, demandando o cotejamento dos benefícios potenciais que dele podem advir.

O controle mais eficaz sobre os gastos públicos é, sem dúvida, a conjunção dos sistemas de controle interno, controle externo e controle da sociedade que, tendo informações à disposição, exercerá monitoramento permanente dos recursos públicos alocados.

A abertura para a participação social no círculo de controle não advém somente dos altos custos de transação ${ }^{144}$ a fim de se alcançar um controle perfeito sobre a dinâmica do Estado. Sua fundamentação reside, prima facie, na insuficiência dos sistemas de controle engendrados na separação de poderes (Régis de Oliveira, 2008, p. 305) teorizada no século XVIII e pelo fato de que a Carta de 1988 estabelece um sistema de ampla participação que ultrapassa os limites da representação democrática indireta. Para Sérgio Assoni Filho (2009, p. 52),

Sem erro pode-se afirmar que a democracia moderna não se sustenta na teoria monstesquiana de fiscalização recíproca entre poderes. Com certeza, aceita-se a premissa de que todo aquele que detém o poder tende a dele abusar. (...) Logo, não só se impõe que o poder controle o poder, mas que o povo o controle também.

Dessa forma, a sociedade deve suprir as lacunas e omissões inerentes aos sistemas tradicionais de controle, atenuando, por meio do monitoramento direto da gestão pública, os conflitos de agência existente entre administrados e administradores.

À luz disso, a Constituinte erigiu a formação de uma esfera pública não estatal, apta a permitir e incentivar a participação social. Contudo, a efetiva participação envolve certos pressupostos, sob pena de tornar-se retórica vazia. Esta legitimidade pode ser organizada por meio conselhos de participação popular, cuja criação e funcionamento deve pressupor autonomia e recursos humanos e materiais, a serem providos pelo Poder Público.

Uma contribuição para que os instrumentos de governança estejam sempre integrados e em efetivo funcionamento seria a criação de um conselho para a governança republicana. Esse conselho, formado por agentes públicos, membros da sociedade civil e de órgãos de controle da Administração, seria criado no âmbito de cada

${ }^{144}$ Cf. COASE, Ronald. op. cit., p. 386-405. 
Poder, com projeções em cada órgão. Uma possibilidade é que esse conselho esteja ligado aos serviços de Ouvidoria, dada sua forte relação com as demandas dos cidadãos. Sua função precípua seria a de acompanhar, incentivar e colaborar na criação e aprimoramento dos instrumentos de governança republicana do Estado.

Para que o conselho possa alcançar suas finalidades, sua composição deve se dar com a participação da sociedade e seus membros devem ter mandato com prazo definido. Mais do que isto, as atribuições do conselho devem ser estabelecidas em norma legal, onde esteja prevista a sua atuação junto aos órgãos públicos envolvidos, monitorando a atuação e auxiliando no aprimoramento dos sistemas de governança pública.

Um dos obstáculos para o exercício dessa modalidade de controle social é a partidarização ou a particularização de interesses mediados por essa sistemática de participação da sociedade. Nos dois casos a atuação com viés político ou particular pode distanciar os resultados dos interesses da sociedade, estabelecendo-se outro conflito de agência exatamente onde se deveria atenuar os conflitos originais entre gestor e cidadão. É o que Marcur Olson (1971) chama de "lógica da ação coletiva", uma abordagem segundo a qual qualquer organização envolve custos, e.g., custos de informação, de oportunidade e custos de fracasso. Dessa forma, tais custos desencorajam grupos de usuários a se organizarem visto que seus benefícios são atomizados na coletividade. Assim, atraem-se formações cartelizadas de interesses por meio das quais o controle social deixa de existir.

Para o conselho de governança republicana proposto anteriormente, a solução possível é a sua institucionalização junto a um terceiro desinteressado, cuja participação seja concretizada pelo trabalho de interlocução entre cidadãos e burocracia estatal, que Marianne Nassuno (1997, p. 31) identifica na pessoa do ombudsman ${ }^{145}$.

Vale reforçar que qualquer iniciativa de controle de eficiência ou monitoramento de resultados deve estar inserido no fenômeno do governo eletrônico ou $e$ governo, como já visto anteriormente.

\footnotetext{
145“'Como exemplo desses mecanismos, pode ser citado o ombudsman (...) A rigor, não tem poderes, apenas atribuições e certos direitos a elas inerentes, como os de solicitar informações e requisitar documentos (...) Mesmo depois de apreciada a queixa e apurada sua procedência, não the cabe rever decisões ou tomar diretamente qualquer medida corretiva. No máximo, sugere ou recomenda alguma providência."
} 


\subsection{Responsabilidade fiscal e governança republicana}

A convergência das matérias tratadas anteriormente consolida-se, sem dúvida, na Lei de Responsabilidade, que não deixa de ser, em última análise, um registro das práticas de governança republicana em matéria de gestão dos recursos públicos. Entretanto, antes da análise de seus dispositivos, cabe a advertência de Kiyoshi Harada (2002, p. 25), para quem a

A Lei de Responsabilidade Fiscal veio à luz para pôr cobro à crise moral que se abateu sobre a Administração Pública Brasileira. Porém, a manutenção da saúde financeira do Estado depende fundamentalmente da competência e da honestidade dos administradores públicos. Não há lei capaz de transformar incompetente e ímprobo em competente e probo, ainda que tutelada por normas penais.

A Lei de Responsabilidade Fiscal (LRF), Lei complementar 101, de 04 de maio de 2000, é um instrumento de governança por excelência, pois tem como objetivos principais o fortalecimento do planejamento, da transparência, do controle, da eficiência, da responsabilidade na gestão dos recursos públicos e da prestação de contas. No Brasil, cabe ainda ressaltar que, após a edição da LRF foi promulgada a Lei 10.028, de 19 de outubro de 2000, tipificando como ilícitos penais uma série de condutas relacionadas à gestão fiscal e sujeitando o administrador público à aplicação de medidas administrativas e penais no caso de descumprimento dos preceitos da lei.

O fundamento da LRF é a própria Constituição Federal, cujo artigo 163 dispõe que:

Art. 163. Lei Complementar disporá sobre:

I-finanças públicas;

II - dívida pública externa e interna, incluída a das autarquias, fundações e demais entidades controladas pelo Poder Público;

III - concessão de garantias pelas entidades públicas;

IV-emissão e resgate de títulos de dívida pública;

$V$-fiscalização financeira da administração pública direta e indireta;

VI - operações de câmbio realizadas por órgãos e entidades da União, dos Estados, do Distrito Federal e dos Municípios; 
VII - compatibilização das funções das instituições oficiais de crédito da União, resguardadas as características e condições operacionais plenas voltadas ao desenvolvimento regional.

A LRF disciplinou os incisos I, II, III e IV do referido artigo, além do artigo 169 da Constituição Federal, conforme mensagem presidencial $\mathrm{n}^{\mathrm{o}} 485$, relativa ao projeto de lei complementar 18/99, que originou a LRF ${ }^{146}$. Régis de Oliveira (2001b, p.271) observa que, "[...] pela leitura dos demais incisos do art. 163, percebe-se, nitidamente, que se cuida de matéria alheia às finanças públicas [...]”, concluindo pela conformidade da lei quanto a este aspecto.

Assim, restou à LRF a definição mais abrangente dos princípios delineadores da gestão das finanças públicas, além das demais matérias previstas nos incisos II, III e IV do artigo 163 e o artigo $169^{147}$.

Responsabilidade fiscal, segundo Kopits, Jiménez e Manoel (2003, p.2),

[...] es un concepto amplio que se puede aplicar por medio de reglas o de una política discrecional. En la práctica, es un sinónimo de reglas fiscales, es decir, restricciones permanentes sobre el déficit fiscal, sobre el stock de deuda pública, o sobre algún otro indicador global de conducta fiscal. Por lo general, tales reglas - que se pueden implantar en diferentes grados de formalidad institucional — están acompañadas por criterios de transparencia y de un marco presupuestario plurianual consistente con revisiones macroeconómicas.

A LRF, em verdade, teve como fundamento a busca pela moralização da gestão fiscal de todos os entes da federação brasileira e pode ser considerada um marco importante para a instituição de um novo paradigma para a administração pública, estabelecendo a transparência, o planejamento e o equilíbrio nas contas públicas como critérios de responsabilidade fiscal.

Muito embora a edição da Lei tenha se dado em um ambiente de crise econômica internacional, onde se impunha a necessidade de equilíbrio fiscal, seu processo de elaboração iniciou-se com a Reforma Administrativa, que em sua tramitação no Congresso teve adicionado um dispositivo determinando que o presidente da República enviasse ao Legislativo, em 180 dias, um projeto de Lei Complementar para a

\footnotetext{
${ }^{146}$ Cf. KOPITS, George; JIMÉNEZ, Juan Pablo; MANOEL, Alvaro. Responsabilidad fiscal a nivel subnacional: Argentina y Brasil. Disponível em: $<$ http://www.bndes.gov.br/SiteBNDES/export/sites/default/bndes_pt/Galerias/Arquivos/bf_bancos/e000111 7.pdf>. Acesso em: 09 nov. 2009.

${ }^{147} \mathrm{Cf}$. CAMARGO, Guilherme Bueno de. op. cit.
} 
regulamentação do artigo 163 da Constituição Federal, o que acabou sendo promulgado com a Emenda Constitucional $n^{0} 19^{148}$. É a partir do disposto na EC $n^{\circ} 19$ que o Poder Executivo Federal iniciou as discussões e os estudos para a elaboração de um projeto de lei complementar para a regulamentação das finanças públicas brasileiras.

A LRF teve inspiração em experiências internacionais, especialmente da Nova Zelândia, que em 1994 editou sua versão para a responsabilidade fiscal ${ }^{149}$. Assim, a Nova Zelândia foi um dos primeiros países a adotar uma legislação específica para a regulamentação da gestão fiscal.

Nesse sentido, Graham Scott (1195, p. 5) ${ }^{150}$ sumariza quatro pontos da discussão ocorrida no processo de promulgação do Fiscal Responsibility Act da Nova Zelândia:
a) estabelecer explicitamente quais são as características de uma gestão fiscal responsável;
b) encorajar uma racionalidade de médio a longo prazo na condução dos assuntos públicos;
c) prover um mecanismo que seja compatível com flutuações a curto prazo;
d) reconhecer que os governos devem partir de diretrizes ou objetivos políticos próprios, mas todas as suas atividades devem ser justificadas, logo transparentes.

Uma das experiências mais significativas da adoção desse novo modelo fiscal vem da Europa, com o Tratado de Maastricht, de 1992, que estabeleceu as diretrizes para a formação da União Europeia. Um dos aspectos abordados no tratado diz respeito às finanças públicas, com ênfase no equilíbrio fiscal dos países membros. Estabelece metas e critérios para indicadores macroeconômicos, endividamento e déficits, os quais devem ser atingidos paulatinamente.

Assim, reza o Tratado que os Estados-membros devem evitar déficits governamentais excessivos, havendo monitoramento constante da situação orçamentária e

\footnotetext{
${ }^{148}$ A Emenda Constitucional 19, que tratou da Reforma Administrativa, iniciou sua tramitação em 1995 na Câmara dos Deputados, com a remessa do projeto pelo Executivo. Lá foi introduzido o dispositivo do artigo 30, in verbis: "Art. 30. O projeto de lei complementar a que se refere o art. 163 da Constituição Federal será apresentado pelo Poder Executivo ao Congresso Nacional no prazo máximo de 180 (cento e oitenta) dias da promulgação desta Emenda".

${ }^{149}$ Fiscal Responsibility Act, de 1994.

${ }^{150}$ SCOTT, Graham. New Zealand's Fiscal Responsibility Act. Agenda, v. 2, n. 1, p. 5, 1995.
} 
situação da participação dívida/PIB, bem como previsão de sanções em caso de descumprimento das metas ${ }^{151}$.

De fato, a preocupação que levou à promulgação da LRF não pode ser vista com um fenômeno exclusivamente brasileiro. A construção de um poder público dissociado de certos vícios ao mesmo passo em que este se torna um espaço de inclusão dos representados é um objetivo mundial.

No sentido de delimitar o objeto proposto neste trabalho, cumpre destacar que a LRF pode ser analisada sob duas perspectivas diversas, porém complementares. A primeira ocupa-se da moldura normativa necessária para o equilíbrio fiscal e a estabilidade macroeconômica. Já a segunda, de forma complementar, trata exatamente de institucionalizar mecanismos de governança republicana, protegendo os interesses da sociedade e dos cidadãos. Trata-se de norma que tem a finalidade de consolidar o engajamento da sociedade civil sob a ótica do Direito Financeiro.

Tendo como objeto a segunda perspectiva da LRF, qual seja, a de refletir-se como um instrumento de governança republicana dirigido aos cidadãos, deve-se destacar quais são as diretivas que interessam para sua interpretação. Entretanto, serão destacados apenas aspectos que, dentro do escopo deste trabalho, tenham a governança republicana como vetor de interpretação.

\section{Do artigo $1^{\circ}$}

Art. $1^{o}$ Esta Lei Complementar estabelece normas de finanças públicas voltadas para a responsabilidade na gestão fiscal, com amparo no Capítulo II do Título VI da Constituição.

$\S I^{o}$ A responsabilidade na gestão fiscal pressupõe a ação planejada e transparente, em que se previnem riscos e corrigem desvios capazes de afetar o equilíbrio das contas públicas, mediante o cumprimento de metas de resultados entre receitas e despesas e a obediência a limites e condições no que tange a renúncia de receita, geração de despesas com pessoal, da seguridade social e outras, dividas consolidada e mobiliária, operações de crédito, inclusive por antecipação de receita, concessão de garantia e inscrição em Restos a Pagar.

\footnotetext{
${ }^{151}$ Uma comissão deve monitorar as finanças públicas de cada membro, propondo, em caso de descumprimento de metas, medidas que vão desde um relatório com recomendações técnicas para ajuste até a obrigatoriedade de o Estado-membro depositar quantia junto à Comunidade até que o déficit seja corrigido.
} 
Nos objetivos enunciados na Lei é possível observar a simetria entre uma gestão fiscal "planejada e transparente" e os princípios da boa governança republicana. Nesse sentido, Régis de Oliveira (2008, p. 399) é enfático ao defender que, com a edição da LRF, "não mais os desmandos, a corrupção, os atos insensatos, o compadrio, o filhotismo, o coronelismo a dar ordens aos agentes públicos”.

Em outras palavras, a boa gestão fiscal fundamenta-se no equilíbrio fiscal, mediante o cumprimento de metas de resultados, conjugado com o requisito da transparência, visando-se à segurança macroeconômica agregada, com a vinculação de todos os entes da federação a esses pressupostos.

\section{Dos artigos $9^{\circ}, \S 4^{\circ}$ e $\S 5^{\circ}, 48$ e 48-A}

Art. $9^{\circ}$ Se verificado, ao final de um bimestre, que a realização da receita poderá não comportar o cumprimento das metas de resultado primário ou nominal estabelecidas no Anexo de Metas Fiscais, os Poderes e o Ministério Público promoverão, por ato próprio e nos montantes necessários, nos trinta dias subsequentes, limitação de empenho e movimentação financeira, segundo os critérios fixados pela lei de diretrizes orçamentárias.

$\S 4^{o}$ Até o final dos meses de maio, setembro e fevereiro, o Poder Executivo demonstrará e avaliará o cumprimento das metas fiscais de cada quadrimestre, em audiência pública na comissão referida no $\S I^{\underline{o}}$ do art. 166 da Constituição ou equivalente nas Casas Legislativas estaduais e municipais.

$\S 5^{\circ}$ No prazo de noventa dias após o encerramento de cada semestre, o Banco Central do Brasil apresentará, em reunião conjunta das comissões temáticas pertinentes do Congresso Nacional, avaliação do cumprimento dos objetivos e metas das políticas monetária, creditícia e cambial, evidenciando o impacto e o custo fiscal de suas operações e os resultados demonstrados nos balanços.

Art. 48. São instrumentos de transparência da gestão fiscal, aos quais será dada ampla divulgação, inclusive em meios eletrônicos de acesso público: os planos, orçamentos e leis de diretrizes orçamentárias; as prestações de contas e o respectivo parecer prévio; o Relatório Resumido da Execução Orçamentária e o Relatório de Gestão Fiscal; e as versões simplificadas desses documentos.

Parágrafo único. A transparência será assegurada também mediante:

I - incentivo à participação popular e realização de audiências públicas, durante os processos de elaboração e discussão dos planos, lei de diretrizes orçamentárias e orçamentos; 
II - liberação ao pleno conhecimento e acompanhamento da sociedade, em tempo real, de informações pormenorizadas sobre a execução orçamentária e financeira, em meios eletrônicos de acesso público;

III - adoção de sistema integrado de administração financeira e controle, que atenda a padrão mínimo de qualidade estabelecido pelo Poder Executivo da União e ao disposto no art. 48-A.

Art. 48-A. Para os fins a que se refere o inciso II do parágrafo único do art. 48, os entes da Federação disponibilizarão a qualquer pessoa física ou jurídica o acesso a informações referentes a:

I - quanto à despesa: todos os atos praticados pelas unidades gestoras no decorrer da execução da despesa, no momento de sua realização, com a disponibilização mínima dos dados referentes ao número do correspondente processo, ao bem fornecido ou ao serviço prestado, à pessoa física ou jurídica beneficiária do pagamento e, quando for o caso, ao procedimento licitatório realizado;

II - quanto à receita: o lançamento e o recebimento de toda a receita das unidades gestoras, inclusive referente a recursos extraordinários.

Esses dispositivos demonstram a preocupação do legislador com o monitoramento permanente da gestão fiscal, possibilitando a correção de rumos para que sejam garantidos os resultados pré-estabelecidos. Em sua essência, tais normas estão englobadas pelas considerações acerca da transparência e da accountability.

Importante aspecto desempenhado pela LRF, como norma norteadora da governança republicana, é o fortalecimento das dimensões de transparência e controle da gestão fiscal, tanto assim o é que o assunto mereceu pormenorização recente pelo legislador (Lei Complementar 131/2009), que alterou a redação dos artigos e incluiu o artigo 48-A.

De fato, o legislador estabeleceu para o gestor público o dever de elaborar e tornar público uma série de relatórios, avaliações e apurações que permitem conhecer os riscos ao equilíbrio fiscal e as repercussões macroeconômicas da gestão financeira estatal. Como já visto anteriormente ao ser abordado o princípio da transparência, os numerosos relatórios, que devem ser elaborados periodicamente pela Administração, facilitam a atividade de controle interno e externo, mas se mostram inadequados para o exercício do controle social. Muito embora não se questione a utilidade dos mesmos, o certo é que tais relatórios não se prestam a informar o cidadão. A uma porque sua publicidade fica, de fato, reservada aos técnicos em razão da complexidade de 
acesso do cidadão comum a elas. A duas porque tais dados e relatórios carecem de "tradução" para a linguagem do leigo, ou seja, do cidadão comum que não conhece, por óbvio, as terminologias e não tem condições de interpretar tais informações por conta própria. Daí a necessidade de que o Poder Público, por meio do conselho de governança proposto anteriormente, cumpra o papel de efetivamente informar a sociedade sobre a gestão fiscal e financeira. Ao fortalecer a necessidade de adoção de uma nova política de transparência, é de se ressaltar que, além das considerações já realizadas acerca desse tema, estes artigos trazem três elementos inovadores nas relações entre Estado e cidadão, a saber: (1) dever de facilitar o acompanhamento da gestão financeira em tempo real; (2) utilização de meios eletrônicos e tecnologia da informação e (3) padrão mínimo de qualidade da informação.

A par dessas inovações, possibilitadas pelas rápidas transformações tecnológicas, é preciso deixar claro que a gestão financeira do Estado não é mais assunto reservado aos gestores públicos, mas questão de interesse da sociedade e de cada cidadão, decorrente dos seus direitos republicanos.

\section{Do art. 59, I}

Art. 59. O Poder Legislativo, diretamente ou com o auxílio dos Tribunais de Contas, e o sistema de controle interno de cada Poder e do Ministério Público, fiscalizarão o cumprimento das normas desta Lei Complementar, com ênfase no que se refere a:

I - atingimento das metas estabelecidas na lei de diretrizes orçamentárias;

Neste dispositivo, a LRF reforça o pilar de controle como fundamento do sistema de governança republicana. Sob esse aspecto, que será melhor abordado no capítulo seguinte, as únicas observações pertinentes são sobre: (1) a abrangência dos sistemas de controle, que pela LRF devem incluir o controle interno de todos os Poderes, o controle externo, desenvolvido pelos tribunais de contas, além do controle exercido pelo Ministério Público e (2) o foco no atingimento de metas, fortalecendo a gestão por resultados. 


\section{Do art. 67}

Art. 67. O acompanhamento e a avaliação, de forma permanente, da política e da operacionalidade da gestão fiscal serão realizados por conselho de gestão fiscal, constituído por representantes de todos os Poderes e esferas de Governo, do Ministério Público e de entidades técnicas representativas da sociedade, visando a:

I - harmonização e coordenação entre os entes da Federação;

II - disseminação de práticas que resultem em maior eficiência na alocação e execução do gasto público, na arrecadação de receitas, no controle do endividamento e na transparência da gestão fiscal;

III - adoção de normas de consolidação das contas públicas, padronização das prestações de contas e dos relatórios e demonstrativos de gestão fiscal de que trata esta Lei Complementar, normas e padrões mais simples para os pequenos Municípios, bem como outros, necessários ao controle social;

IV - divulgação de análises, estudos e diagnósticos.

Este talvez seja um dos dispositivos mais relevantes para as boas práticas de governança republicana até aqui abordadas. Infelizmente, a letra da lei não passou à realidade, de modo que este artigo até o momento não tem eficácia, a despeito da enorme importância para a sociedade. É, pois, o que José Afonso da Silva (2004, p. 126) chama de normas constitucionais de princípios institutivos, ou seja, "aquelas através das quais o legislador constituinte traça esquemas gerais de estruturação e atribuições de órgãos, entidades e institutos, para que o legislador ordinário as estruture em definitivo, mediante lei”.

Em teoria, o Conselho da Gestão Fiscal seria responsável pela guarda de LRF em sua dimensão prática, na medida em que verificaria e proporia soluções para os problemas em sua aplicação. Ademais, por ser um órgão de concentração e organização de informações, também contribuiria para efetivar a transparência e atenuar a assimetria de informações entre Estado e sociedade. Não obstante, também possui a função de criar uma espécie de "laboratório de boas práticas" de gestão fiscal e, por que não, de governança republicana.

Portanto, não resta surpresa na advertência feita por Amir Khair (2006) de que a ausência desse conselho compromete a efetividade da LRF, tornando difícil a 
solução de conflitos quanto à interpretação de seus dispositivos, além de ainda não ser possível utilizar os bons exemplos premiando os bons governantes.

Ademais, considerando-se a proposta de instituição de conselhos de governança vinculados aos diversos órgãos públicos, esse Conselho de Gestão Fiscal poderia ser a instância superior do sistema de governança, estabelecendo diretrizes, traçando orientações gerais e dirimindo eventuais conflitos ${ }^{152}$. Tem-se, pois, que a criação do Conselho de Gestão Fiscal é imprescindível para o completo funcionamento dos mecanismos de governança republicana em matéria de finanças públicas.

\footnotetext{
${ }^{152}$ Amir Khair (KHAIR, Amir. Lei de Responsabilidade Fiscal: avanços e aperfeiçoamento necessários. In: MENDES, Marcos (Org.). Gasto público eficiente: 91 propostas para o desenvolvimento do Brasil. São Paulo: TopBooks, 2006. p. 314-315) ainda elenca uma série de outros problemas que poderiam ser solucionados na aplicação da LRF com a instituição do Conselho de Gestão Fiscal: "a) Simplificação da prestação de contas dos pequenos municípios; b) Padronização das prestações de contas de todos os entes; c) Premiação dos resultados meritórios; d) Definição dos critérios contábeis que ajudariam a reduzir a "contabilidade criativa" e maquiagem de receitas e despesas; e) Coordenação do esforço de implementação da Lei por todos os órgãos envolvidos através de cursos, cartilhas e encontros técnicos; f) Resolução das dificuldades práticas na implementação de procedimento exigidos pela LRF; g) Atenuação dos conflitos de interesses entre os outros fiscais da LRF; h) Vedação do uso de interpretação ad hoc da LRF ao sabor das necessidades momentâneas".
} 


\section{CONTROLE DA ADMINISTRAÇÃO E GOVERNANÇA REPUBLICANA}

O funcionamento de um sistema integrado de controle é requisito essencial para a boa governança republicana.

Conrado Wargas Neto (2006, p. 170) recorda Aliomar Baleeiro, que afirmou que "O regime democrático é o da responsabilidade dos agentes ou titulares dos três Poderes perante os concidadãos, que têm o direito a acesso às fontes de informação sobre os negócios públicos" 153 . É, portanto, atividade inerente ao sistema republicano e característica dos regimes democráticos ocidentais, cujo desenvolvimento institucional se deu a partir do século XVIII, com a divisão de poderes e os sistemas de checks and balances.

Historicamente, uma das mais importantes contribuições para a institucionalização da atividade de controle da Administração Pública como mecanismo inerente aos sistemas democráticos foi a Déclaration des Droits de L’homme et du Citoyen, de 1789. Em seu artigo XV dispõe que "a sociedade tem direito de pedir a todo o agente público a prestação de contas de sua administração"154.

O constitucionalismo contemporâneo tem a característica de ser sistêmico. ${ }^{155}$ Isto porque dele participam, integradamente, o Poder Legislativo (Congresso Nacional, Assembleias Legislativas e Câmaras Municipais, nos correspondentes níveis da Federação), auxiliado pelos Tribunais de Contas, o Executivo e o Judiciário.

E para que o sistema seja equilibrado, é preciso que a atividade de controle, além de integrada, seja ampla, envolvendo, no caso da gestão financeira, os aspectos da governança republicana. Essa concepção de controle da Administração Pública coincide com a dada por Edmir Netto de Araújo (2009, p. 1147), para quem o controle que interessa ao Direito Administrativo não se limita à aferição estrita da legalidade, mas “[...] também da oportunidade/conveniência, interesse público, legitimidade, moralidade, eficiência, impessoalidade e outros princípios [...]".

\footnotetext{
${ }^{153}$ (RTJ 50:249).

154“Article XV: La Société a le droit de demander compte à tout Agent public de son administration"

${ }^{155}$ Cf. TORRES, Ricardo Lobo. Curso de direito financeiro e tributário, cit., p. 202.
} 
Ricardo Lobo Torres (2005, p. 202) ensina que

[...] a palavra controle, que não é portuguesa (em Portugal usa-se controlo), ingressou na linguagem constitucional brasileira a partir de 1964, após a sua universalização no direito orçamentário francês (controle), espanhol (control), americano (control) e alemão (Finanzkontrolle).

Assim, no Brasil a atividade de controle tem fundamento constitucional $^{156}$, observando Benjamin Zymler (1998, p. 36) que,

[...] diferentemente das constituições passadas, a Carta Política de 1988 estatui que os três Poderes da União manterão, de forma integrada, sistema de controle interno dentro de suas respectivas estruturas administrativas. Com isso, foi conferida maior autonomia aos Poderes Legislativo e Judiciário, acentuando as características de harmonia e independência entre os Poderes.

A Constituição Federal dispõe sobre o controle interno e externo dos atos da administração. Foi, porém, com a Constituição de 1967 que, no capítulo dedicado ao Poder Legislativo, introduziu-se uma sessão destinada à fiscalização financeira $e$ orçamentária, tratando de um controle mais abrangente, articulado em interno e externo, com o Poder Executivo tendo de manter sistema de controle interno, com a finalidade de criar condições indispensáveis para assegurar eficácia ao controle externo e regularidade à realização da receita e da despesa; acompanhar a execução de programas de trabalho e a do orçamento; e avaliar os resultados alcançados pelos administradores e verificar a execução dos contratos (art. 71, CF 1967).

O pleno funcionamento de um sistema articulado de controle dos atos da administração é fundamental para a democracia e é indispensável para a garantia dos direitos republicanos. Ademais, os sistemas de controle, além de possibilitarem a prestação de contas e a responsabilização do agente público, podem servir como poderoso instrumento de aprimoramento da gestão, na medida em que os resultados apurados nas

\footnotetext{
${ }^{156}$ Régis de Oliveira (OLIVEIRA, Régis Fernandes de. op. cit., p. 389) relata que "A primeira Constituição republicana, de 24 de fevereiro de 1891, já previa o controle de legalidade por um tribunal de contas", sendo que as demais também continham disposições sobre controle da Administração.
} 
atividades de controle podem servir como subsídio para a tomada de decisões e para ajustes na execução de políticas públicas ${ }^{157}$. Ruy Remy Rech $(2003$, p. 2) entende que

\begin{abstract}
É bom administrador aquele que sabe tirar proveito do controle, pois através dele obtém informações sobre o plano organizacional, quanto à sua dinâmica e eficácia; sobre a execução dos projetos e atividades, se está de conformidade, ou não, com o planejamento; sobre o comportamento dos agentes e promotores da execução de projetos e de atividades, e do seu grau de adesão às políticas da Administração; sobre o comportamento da ação executiva e do nível de consecução das metas estabelecidas; e sobre os resultados obtidos, em confronto com as metas planejadas.
\end{abstract}

Sob a ótica da governança republicana, a atividade de controle é uma das mais importantes para a proteção do interesse público na gestão financeira do Estado. Nesse sentido, Benjamin Zymler (1998, p. 18) entende que o controle da Administração deve ser visto "dentro de uma visão Republicana do Estado Brasileiro, cuja Constituição elege a prestação de contas dos agentes públicos, que cuidam da res publica, como princípio sensível, ou seja, princípio cuja violação enseja a intervenção federal ou estadual (art. 34, VII, d, e art. 35, II)".

Ruy Remy Rech (2003, p. 1) esclarece que "ao complexo de atividades relacionadas com o acompanhamento dos atos e fatos da administração, organizado para assegurar sucesso na realização de seus fins, designa-se Ação de Controle”.

Já para Edmir Netto de Araújo (2009, p. 1148), Controle da Administração é

[...] o conjunto de mecanismos e atividades, jurídicos, jurisdicionais e administrativos, para o exercício da fiscalização e revisão que sobre ela exercem órgãos dos Poderes Judiciário, Legislativo e do próprio Executivo, às vezes como faculdade de vigilância, orientação e correção, outras como poder-dever indisponível, objetivando a conformação da atuação do agente, órgão ou entidade à legalidade, conveniência,

\footnotetext{
${ }^{157}$ Cf. Ruy Remy Rech (RECH, Ruy Remy. Controle interno na administração pública. Diário Eletrônico do Tribunal de Contas do Estado do Rio Grande do Sul, 2003. p. 2. Disponível em: $<$ http://www.tce.rs.gov.br/artigos/pdf/controle-interno-administracao-publica.pdf>. Acesso em: 30 out. 2009) observa que "o controle constitui um dos princípios basilares da Administração, de tal forma que a inexistência dessa função ou as deficiências que apresentar têm reflexos diretos e negativos com a mesma intensidade nas demais funções (organização, planejamento e comando), decretando invariavelmente a frustração parcial ou total dos seus objetivos. Os resultados medíocres ou desastrosos na administração pública ou privada têm sempre como responsáveis as falhas do controle, de igual forma como o sucesso repousa fundamentalmente na sua eficiência".
} 
oportunidade, supremacia do interesse público e outros princípios que decorrem do ordenamento jurídico.

Dado que a Administração submete-se necessariamente a controle, cabe definir quem o exerce.

Pela lógica engendrada na Constituição Federal, a Administração Pública é reciprocamente controlada pelos Poderes Legislativo, Executivo, Judiciário e por si mesma, quando controla seus próprios atos. Nesse sentido, Régis de Oliveira (2008, p. 390) chama a atenção para a amplitude trazida pela Constituição Federal de 1988, que estabeleceu que a fiscalização patrimonial, operacional e financeira abrange as entidades da administração direta e indireta, ao contrário da Constituição anterior, que limitava essa atividade à administração direta da União. No mesmo sentido, Hely Lopes Meirelles (2009, p. 712) garante que "a fiscalização financeira e orçamentária é conferida em termos amplos pelo Congresso Nacional, mas se refere fundamentalmente à prestação de contas de todo aquele que administra bens, valores ou dinheiros públicos"158.

Além disso, embora o controle da Administração seja atribuição do Estado, a Constituição Federal conferiu ao administrado instrumentos para que também dele participe, provocando-o. Pode fazê-lo não só na defesa de interesses individuais, mas também no interesse coletivo. A Emenda Constitucional nº19/98 acrescentou o $§ 3^{\circ}$ do art. 37 da Constituição, que estabelece que

Art. 37.

$\S 3^{\circ}$ - Lei disciplinará as formas de participação do usuário na administração pública direta e indireta, regulando especialmente:

I - as reclamações relativas à prestação dos serviços públicos em geral, asseguradas a manutenção de serviços de atendimento ao usuário e a avaliação periódica, externa e interna, da qualidade dos serviços;

II - o acesso dos usuários a registros administrativos e a informações sobre atos de governo, observado o disposto no art. $5^{\circ}$, X e XXXIII;

III - a disciplina da representação contra o exercício negligente ou abusivo de cargo, emprego ou função na administração pública.

Trata-se, conforme Maria Sylvia Zanella di Pietro (2009, p. 690), do "mais eficaz meio de controle da Administração Pública: o controle popular." O

\footnotetext{
${ }^{158}$ Hely Lopes Meirelles (MEIRELLES, Hely Lopes. op. cit., p. 712) explica que "É decorrência natural da administração como atividade exercida em relação a interesses alheios. Não é, pois, a natureza do órgão ou da pessoa que a obriga a prestar contas; é a origem pública do bem administrado ou do dinheiro gerido que acarreta para o gestor o dever de comprovar seu zelo e bom emprego."
} 
dispositivo em tela reforça a ideia de que o cidadão é o titular da res publica e a garantia de que seu direito republicano será assegurado, ou seja, é a aplicação concreta dos mecanismos de governança republicana estabelecidos no ordenamento pátrio. Lamentavelmente, a lei ainda não foi promulgada, mas seria importante instrumento à disposição do cidadão.

O mecanismo de controle previsto no artigo 37 da Constituição é também denominado de controle vertical ${ }^{159}$, ou seja, aquele realizado diretamente pelo cidadão, que passa a fiscalizar a Administração, tanto nas atividades cotidianas, como nos resultados por ela produzidos, em confronto com as metas e objetivos traçados.

De outra banda, o sistema tradicional de controle institucional, chamado de horizontal, é o controle interno e o externo, realizado pelos Poderes entre si.

Assim, do ponto de vista do órgão que o exerce, o controle pode ser classificado como legislativo, administrativo ou judicial. Conforme o momento pode ser prévio, concomitante ou posterior e, se decorrer de órgão integrante ou não da estrutura em que se encontra o órgão controlado, interno ou externo ${ }^{160}$. Todos os tipos se inserem, sistemicamente, na categoria do que a Constituição Federal amplamente denomina de fiscalização contábil, financeira, operacional e patrimonial.

Sobre a classificação do momento em que se realiza o controle, Maria Sylvia Zanella di Pietro (2009, p. 726) exemplifica o controle concomitante com o acompanhamento da execução orçamentária pelo sistema de auditoria, ao longo do exercício. Já o controle posterior, ainda no campo na gestão financeira, pode ser bem ilustrado com as auditorias internas e externas realizadas nas contas da Administração. Já o controle prévio, no campo do Direito Financeiro, encontra lugar, por exemplo, no exame das formalidades e requisitos para realização de determinada despesa.

\footnotetext{
${ }^{159}$ Têmis Limberger (LIMBERGER, Têmis. Transparência administrativa e novas tecnologias: o dever de publicidade, o direito a ser informado e o princípio democrático. Revista de Direito Administrativo, Rio de Janeiro, v. 244, p. 257, jan./abr. 2007) destaca que "Esta proposição de controles horizontais e verticais foi desenvolvida por Karl Loewenstein. Para o citado autor, os controles horizontais são aqueles que se operam de dentro de um determinado poder (intraorgânico) ou entre diversos detentores de poder (interorgânicos). Os controles horizontais se movem lateralmente, no mesmo aparato de domínio, sendo que os controles verticais funcionam em uma linha ascendente e descendente entre a totalidade dos poderes instituídos e a comunidade, por meio de seus componentes".

${ }^{160}$ Cf. DI PIETRO, Maria Sylvia Zanella. op. cit., p. 725).
} 
Benjamin Zymler (1998, p. 17) ensina que, de modo geral, “o controle desenvolve-se, via de regra, em quatro fases: estabelecimento de metas, observação do desempenho, comparação do desempenho com as metas estabelecidas e ação corretiva".

Ruy Remy Rech (2003, p. 3) aponta que "integrados - controle interno, controle externo e administração -, cumpre-lhes promover a realização do bem público, para permitir a obtenção do resultado máximo, com o mínimo de recursos, sem desvios e desperdícios. A interação de ambos é que forma o denominado "Sistema de Controle". Além disso, para Ruy Remy Rech (2003, p. 3), as finalidades do Sistema de Controle são:

1) assegurar eficácia, eficiência e economicidade na Administração Pública e aplicação dos recursos públicos;

2) evitar desvios, perdas e desperdícios;

3) garantir o cumprimento das normas técnicas, administrativas e legais;

4) identificar erros, fraudes e seus agentes;

5) preservar a integridade patrimonial e

6) propiciar informações para a tomada de decisões.

No que tange à evolução dos sistemas de controle da Administração, pode-se dizer que houve alguma concomitância com as reformas introduzidas na gestão pública. Os sistemas de controle são, por óbvio, reflexo da estrutura jurídica, política e administrativa do Estado $^{161}$. Desse modo, no estágio atual do Estado democrático brasileiro, é natural que as estruturas de controle existentes devam funcionar tendo como prioridade a defesa do interesse público e a participação social no controle.

Hely Lopes Meirelles (2009, p. 712-713) ressalta a importância da atividade de fiscalização da administração financeira e orçamentária, pois que os atos nessa seara têm repercussão imediata no erário e, portanto, na res publica. Por essa razão,

\footnotetext{
${ }^{161}$ Ruy Remy Rech (RECH, Ruy Remy. op. cit., p. 2) recorda que "a modernização do sistema de controle veio com a denominada Reforma Administrativa, introduzida pela Constituição de 1967 e designadamente através do Decreto-Lei ${ }^{\circ} 200$, de 20 de fevereiro do mesmo ano. O novo modelo permitiu, desde então, a utilização da prática de acompanhamento dos atos de gestão e de administração de forma mais ágil, abandonando-se o modelo superado, que, embora minudente, preocupava-se mais com o aspecto formal, revelando-se, por isso, ineficaz e viciado. Passou-se a adotar, então, o processo de auditorias financeiras e orçamentárias". Em seguida, o mesmo autor reconhece que "hoje o controle encontra-se num estágio ainda mais avançado e estrutura-se, basicamente, sobre princípios de comprovada eficiência. Espelha-se nos modelos aplicados aos grandes conglomerados empresariais do mundo desenvolvido".
} 
entende o autor que a Constituição "submeteu a maiores rigores de acompanhamento" os atos envolvendo recursos públicos, determinando o "controle interno pelo Executivo e o controle externo pelo Congresso Nacional auxiliado pelo TCU (artigos 70 a 75). Além dessas normas constitucionais, a Lei 4.320, de 17.3.64, dispõe sobre a elaboração e controle dos orçamentos e balanços da União, dos Estados, dos Municípios e do Distrito Federal".

\subsection{O controle interno}

É a Constituição Federal que determina que os Poderes Legislativo, Executivo e Judiciário manterão, de forma integrada, sistema de controle interno com a finalidade de: avaliar o cumprimento das metas previstas no plano plurianual, a execução dos programas de governo e dos orçamentos da União; comprovar a legalidade e avaliar os resultados, quanto à eficácia e eficiência, da gestão orçamentária, financeira e patrimonial nos órgãos e entidades da administração federal, bem como da aplicação de recursos públicos por entidades de direito privado; exercer o controle das operações de crédito, avais e garantias, bem como dos direitos e haveres da União; apoiar o controle externo no exercício de sua missão institucional (artigo 74 e incisos, CF).

Maria Sylvia Zanella di Pietro (2009, p. 726) ressalta que

[...] o artigo 74 da Constituição inova de várias maneiras: primeiro, ao deixar claro que cada um dos poderes terá um sistema de controle interno; segundo, ao prever que esse sistema se exercerá de forma integrada entre os três Poderes; terceiro, ao estabelecer a responsabilidade solidária dos responsáveis pelo controle quando, ao tomarem conhecimento de irregularidades, deixarem de dar ciência ao Tribunal de Contas $\left(\S 1^{\circ}\right)$; finalmente, ao colocar o Tribunal de Contas como uma espécie de ouvidor geral a quem os cidadãos, partidos políticos, associações ou sindicatos podem denunciar irregularidades ou ilegalidades $\left(\S 2^{\circ}\right)$.

Os avanços na forma como a atividade de controle vem sendo tratada não são tão recentes e, como já dito, coincidem com as reformas que a gestão pública vem sofrendo. Hely Lopes Meirelles (2009, p. 715) aduz que,

[...] é de se observar que desde a Constituição de 1967 vigora no Brasil uma orientação no controle orçamentário e financeiro visando a substituir as meras verificações formais de comprovação da despesa pelo 
acompanhamento efetivo da conduta contábil e financeira da Administração, quer na execução do orçamento, quer no desenvolvimento dos programas de trabalho.

Em sentido amplo, a Administração vinha exercendo alguma forma de controle interno, compreendendo o próprio controle da execução orçamentária. Como uma forma específica de gerenciamento da administração financeira e orçamentária, porém, foi só com a Lei 4.320/64 que o controle interno tomou forma como tal. ${ }^{162}$ Este controle interno da execução orçamentária compreende a legalidade dos atos de que resultem a arrecadação da receita ou a realização da despesa, o nascimento ou a extinção de direitos e obrigações; a fidelidade funcional dos agentes da administração, responsáveis por bens e valores públicos e o cumprimento do programa de trabalho expresso em termos monetários e em termos de realização de obras e prestação de serviços (art. 75, Lei 4.320/64).

Conforme Mileski (2003, p. 158),

[...] essa nova técnica de controle sobre a execução orçamentária, afastando-se da fiscalização formal, passa a dar ênfase aos procedimentos de auditoria, no sentido de efetuar não só o controle de legalidade dos atos do administrador, mas também o acompanhamento dos programas de trabalho e do orçamento, a fim de serem avaliados os resultados da ação administrativa, revelando-se como um verdadeiro controle de eficiência e de produtividade.

É extremamente relevante o destaque dado à ampliação das funções de controle, já que não apenas o controle interno contemplou-se com a lógica de avaliação de resultados, mas também outras formas de controle. É o que se depreende da lógica do sistema de controle constitucionalmente estabelecido, que, nos princípios referentes à Administração Pública, fala não apenas em legalidade, mas também em eficiência (caput do art. 37) e, quanto à fiscalização, refere-se àquele que se realiza sobre a legalidade, a legitimidade e a economicidade (art. 70).

O Banco Interamericano de Desenvolvimento (Rech, 2003, p. 3 - apud Auditoria Interna - ILACIFS, Bogotá, Colômbia, p. 105) conceitua controle interno como

\footnotetext{
${ }^{162}$ Cf. MILESKI, Helio Saul. O controle da gestão pública. São Paulo: Ed. Revista dos Tribunais, 2003. p.
} 157. 
el plan de organización y métodos adoptados dentro de una entidad con el fin de proteger e salvaguardar los activos, dificultando la comisión de fraudes o errores no intencionados que se traduzcan en pérdidas; además de asegurar el grado de confianza de la información contablefinanciera, promover la eficiencia operativa y garatizar la adhesión a la política estabelecida por la entidad.

Vê-se que são abrangentes as finalidades dos sistemas de controle interno $^{163}$, que não devem se limitar apenas à verificação de legalidade, legitimidade e formalidade, mas também à avaliação de resultados, de eficiência, de cumprimento de metas e de planejamento. Além disso, o Direito Financeiro ainda impõe vários outros controles específicos, tais como controle do endividamento, das operações de crédito e tantos outros específicos a cada área da Administração Pública. O controle interno, portanto, deve ser uma verdadeira ferramenta de gestão, a ser aplicada antes, durante e após a execução financeira. Nessa linha, segundo Hely Lopes (2009, p. 713), é na sua plenitude, um controle de legalidade, conveniência, oportunidade e eficiência.

Além desses objetivos, o controle interno também tem como finalidade dar suporte ao controle externo, facilitando a tarefa do Tribunal de Contas ou de eventualmente outro órgão que venha a realizar este mister.

Dada a amplitude que a atividade de controle pode ter dentro de uma organização, este trabalho limitar-se-á aos mecanismos relacionados à gestão orçamentária e financeira do Estado.

Nesse aspecto, seria extremamente conveniente que cada órgão da administração dispusesse de uma unidade interna de controle, que ficasse responsável por toda a coleta e processamento de informações orçamentárias e financeiras ${ }^{164}$. Seguindo-se

\footnotetext{
${ }^{163}$ Cf. Benjamin Zymler (ZYMLER, Benjamin. Questões de controle: controle das finanças públicas no Brasil: visão atual e prospectiva. Revista do Tribunal de Contas da União, Brasília, n. 76, p. 36, abr./jun. 1998). Já José Afonso da Silva (SILVA, José Afonso da. Curso de direito constitucional positivo, cit., p. 751-752) relata que "realmente, são finalidades do controle interno, constitucionalmente estabelecidas (art.74): (1) avaliar o cumprimento das metas previstas no plano plurianual, a execução dos programas de governo e dos orçamentos da União; (2) comprovar a legalidade e avaliar os resultados, quanto à eficácia e eficiência, da gestão orçamentária, financeira e patrimonial nos órgãos e entidades da Administração federal, bem como da aplicação de recursos públicos por entidades de direito privado; (3) exercer o controle das operações de crédito, avais e garantias, bem como dos direitos e haveres da União; e (4) apoiar o controle externo no exercício de sua missão institucional, por isso é que se exige dos responsáveis pelo controle interno que dêem ciência, ao Tribunal de Contas de toda e qualquer irregularidade ou ilegalidade de que vierem a ter conhecimento, sob pena de responsabilidade solidária (art. 74, $\S 1^{\circ}$ )".

${ }^{164}$ Victor Faccioni (FACCIONI, Victor José. Sistema de controle interno da Administração Pública Municipal: proposta para instituir controle interno nas administrações municipais. In: ENCONTRO
} 
a proposta sugerida neste trabalho, essa unidade de controle poderia estar ligada ao conselho de governança, prestando informações não só aos gestores, responsáveis diretos pelos resultados e pela própria atividade de controle ${ }^{165}$, mas também à sociedade.

É fundamental, entretanto, que a execução dessa atividade seja empreendida sob novos paradigmas, utilizando-se de ferramentas de tecnologia da informação, além de modelos contábeis e financeiros que reflitam o desempenho e evolução governamental.

Nessa linha já foram apontadas, no item relativo à eficiência do gasto público, alguns instrumentos de aferição de desempenho e avaliação de eficiência, eficácia, economicidade, tais como a apuração do resultado econômico e a gestão de custos aplicada ao setor público. Além disso, para a gestão focada em resultados é imprescindível que o acompanhamento de desempenho seja aferido por meio de indicadores desenvolvidos especificamente para esta finalidade. Sob o aspecto do controle da gestão financeira, Mauro Santos Silva (2001, p. 8) entende que

O universo de indicadores possíveis de serem aferidos por intermédio dos procedimentos de controle sobre o ciclo orçamentário público, tradicionalmente, tem sido divido em dois segmentos. O primeiro, denominado de controle de procedimentos, refere-se ao acompanhamento da legalidade e da legitimidade dos atos. O segundo, identificado como controle de resultados, tem como foco de atuação a verificação dos níveis de eficiência, eficácia, economicidade e efetividade. Ambos, referentes aos atos praticados por aqueles que assumem a responsabilidade política ou administrativa pela gerência de recursos públicos.

NACIONAL DOS TRIBUNAIS DE CONTAS. Belém, 2001. p. 7. Disponível em: <http://www.tce.rs.gov.br/legislacao/controle_interno/pdf/palestra.pdf>. Acesso em: 04 nov. 2009) avança para propor um modelo para os municípios de Controle Interno que "seria integrado pelo Contador, Procurador-Geral do Município, Secretário da Fazenda e o Diretor-Geral da Câmara de Vereadores. Também integrariam o Controle Interno os Secretários da Educação e Saúde, na medida em que suas pastas têm recursos vinculados, e são considerados, perante a lei, gestores. A nomeação destes Secretários, para integrar o Controle Interno, facilitaria o acompanhamento das deficiências destas Secretarias e da aplicação dos seus recursos"

${ }^{165}$ Cf. Ruy Remy Rech (RECH, Ruy Remy. op. cit., p. 5) que entende que "a organização do sistema de controle interno e o seu funcionamento eficiente é da inteira responsabilidade do Administrador, como corolário do dever de bem administrar e de prestar contas. Incumbe ao Administrador, primeiramente, gerir o patrimônio e os recursos a ele confiados com proficiência, sem desperdícios e desvios; em segundo lugar, cumpre-lhe prover as condições para demonstrar a prática da boa administração e permitir a verificação, por parte dos órgãos de controle externo, de que agiu com correção e competência. Uma vez organizado o controle interno, há que mantê-lo sob permanente vigilância e avaliação, pois se sabe que as falhas de seu funcionamento trazem reflexos inevitáveis nos resultados da administração, podendo comprometê-la irremediavelmente". 
Da interpretação do ordenamento pátrio em matéria de Direito Financeiro, é forçoso concluir que há dois aspectos fundamentais ainda pouco aplicados na atividade de controle interno realizada pela Administração. A primeira é que essa atividade deve ser executada de modo a buscar evidências sobre o desempenho governamental, alcançando as dimensões de eficiência, eficácia, rapidez, qualidade e satisfação do cidadão. A segunda é que a atividade de controle deve estar voltada também para a sociedade. $\mathrm{O}$ cidadão deve ser um dos destinatários das informações levantadas pelos órgãos de controle da administração, especialmente as que envolvem a gestão dos recursos públicos. A omissão em uma dessas facetas da atividade de controle deve sujeitar o administrador à responsabilização, pois a este cabe não apenas bem gerir a res publica, mas também prestar contas diretamente ao cidadão. É também o entendimento de Ruy Remy Rech (2003, p. 6), para quem

[...] as falhas originadas de deficiências ou da ausência das funções relacionadas com os sistemas de controle interno, que embaracem a realização das suas finalidades, poderão sempre ser levadas a responsabilidade dos respectivos administradores, na apreciação e julgamento das suas contas pelos órgãos de controle a que estão sujeitos: corporações legislativas, Tribunal de Contas, Ministério Público ou Judiciário.

O Poder Público, quando realiza o controle interno, o faz de diversas formas: auditorias, a fiscalização, o processamento de recursos administrativos, as inspeções, as correições, a supervisão. Hoje há, em algumas esferas, as ouvidorias, que são instituídas para ser um canal direto entre a população e o Poder Público. Além disso, toda e qualquer ação sistematizada de coleta de informação com o objetivo de aferir o desempenho, a legalidade, a legitimidade e os requisitos dos atos da gestão pública pode ser considerada como atividade de controle interno. Ademais, o Poder Público tem o poder-dever de anular seus próprios atos, desde que estejam eivados de ilegalidade ou revogá-los, considerando-se critérios de conveniência e oportunidade ${ }^{166}$. Trata-se, portanto, de uma prerrogativa muito importante para ficar adstrita ao mero controle formal. Deve, pois, o controle interno da Administração, atuar como verdadeiro garantidor da governança republicana, tornando acessível aos cidadãos a apuração do desempenho global da gestão.

\footnotetext{
${ }^{166}$ Cf. Benjamin Zymler (ZYMLER, Benjamin. op. cit., p. 21), que explica que "O poder-dever de autotutela da Administração sobressai da Súmula $n^{\circ} 473$ do Supremo Tribunal Federal, segundo a qual 'A Administração pode anular seus próprios atos, quando eivados de vícios que os tornem ilegais, porque deles não se originam direitos; ou revogá-los, por motivos de conveniência ou oportunidade, respeitados os direitos adquiridos, e ressalvada, em todos os casos, a apreciação judicial”.
} 


\subsection{O controle externo}

O controle externo da Administração é aquele realizado por órgãos alheios aos que realizaram o ato ou ação. Em outras palavras, se o controle é exercido por órgão estranho àquele que é controlado, trata-se de controle externo. Ele compreende o controle parlamentar direto, o controle exercido pelo Tribunal de Contas e o controle jurisdicional.

$\mathrm{Na}$ experiência estrangeira, uma instituição interessante de controle externo é o Conseil d'État francês. Seu papel, segundo Bresser Pereira (2009, p. 140141), é claramente o de defensor da res publica: além de aconselhar o governo, essa organização do Estado constitui um juízo de última instância, embora de caráter administrativo, quando o Estado está envolvido. Ao julgar ações contra o Estado, a abordagem do Conseil d'État é proteger o interesse público; o princípio da supremacia do interesse público é integralmente adotado.

Reforçando a ideia de que, no sistema instituído pela Constituição brasileira, a atividade de controle é fundamental, José Afonso da Silva (2008, p. 752) sustenta que "a fiscalização contábil, financeira, orçamentária, operacional e patrimonial, mediante controle externo, é coerente com Estado Democrático de Direito". Ainda segundo o eminente jurista (2008, p. 752),

Tem por objetivo, nos termos da Constituição, a apreciação das contas do Chefe do Poder Executivo, o desempenho das funções de auditoria financeira e orçamentária, a apreciação da legalidade dos atos e admissões de pessoal, bem como o julgamento das contas dos administradores e demais responsáveis por bens e valores públicos. Em suma, verificar da legalidade, da legitimidade e da economicidade dos atos contábeis, financeiros, orçamentários, operacionais e patrimoniais da administração direta e indireta da União.

Os sistemas de freios e contrapesos adotado na divisão dos Poderes demanda a existência de mecanismo de controle externo. Nessa linha, Francisco Almeida (1999, p. 33-34) considera que, dentre os fundamentos do controle externo, encontram-se tanto o "Pleno Estado Democrático de Direito e seus princípios basilares" como o "direito do homem como cidadão e contribuinte, beneficiário legítimo da receita e da despesa". No mesmo sentido, José Maurício Conti (2006, p. 109) defende que "os sistemas de controle 
constituem-se em importante mecanismo de limitação dos poderes do Estado, colaborando no sistema de freios e contrapesos e evitando que ocorra abuso de poder".

De fato, apenas o controle interno, realizado pelo mesmo agente responsável pelas ações, não é suficiente para a garantia de governança republicana. Assim, órgãos externos que avaliem a gestão propiciam o equilíbrio necessário e a segurança na gestão dos recursos públicos, resguardando o interesse público.

Para Francisco Almeida (1999, p. 18), os objetivos perseguidos pelo controle externo dos atos de gestão são:

a) avaliar a legalidade, legitimidade, economicidade, eficiência, eficácia e efetividade dos atos praticados pelos gestores e demais agentes políticos e administrativos dos órgãos/entidades públicos;

b) examinar, informar e julgar todos os atos e fatos relativos à captação (receitas) e alocação (despesas) de recursos públicos, determinando ou recomendando a adoção das medidas necessárias à efetiva observância dos princípios da moralidade, impessoalidade, publicidade, legalidade, legitimidade, economicidade, eficiência, eficácia e efetividade na administração pública.

Do ponto de vista dos seus destinatários, tanto a administração direta como a indireta estão sujeitas ao controle. É amplo o leque de órgãos e entidades fiscalizados e controlados, alcançando, inclusive, as empresas públicas e as sociedades de economia mista.

Além disso, todo aquele que for responsável por dinheiros, bens e valores públicos da administração direta e indireta estão sujeitos ao controle externo ${ }^{167}$.

Há muitas divergências sobre quem exerce o controle externo ${ }^{168}$. José Afonso da Silva (2008, p. 752-753) assevera que

[...] o controle externo é, pois, função do Poder Legislativo, sendo de competência do Congresso Nacional no âmbito federal, das Assembleias Legislativas nos Estados, da Câmara Legislativa do Distrito Federal e das Câmaras Municipais nos Municípios com o auxílio dos respectivos Tribunais de Contas. Consiste, assim, na atuação da função fiscalizadora

\footnotetext{
${ }^{167}$ Constituição Federal, artigo 70, inciso II.

${ }^{168}$ Celso Antônio Bandeira de Melo (MELLO, Celso Antônio Bandeira de. op. cit., p. 930) leciona que "o controle externo compreende (I) o controle parlamentar direto, (II) o controle exercido pelo Tribunal de Contas (órgão auxiliar do Legislativo nesta matéria) e (III) o controle jurisdicional".
} 
do povo, através de seus representantes, sobre a administração financeira e orçamentária.

Régis de Oliveira (2008, p. 393) também atribui apenas ao Poder Legislativo, com auxílio do Tribunal de Contas, a tarefa de exercer o controle externo. Já Benjamin Zymler (1998, p. 22) entende que "O controle externo pode ser exercido pelo Poder Judiciário e pelo Poder Legislativo". Essa também a posição de Edmir Netto de Araújo (2009, p. 1169), para quem o controle externo pode ser exercido diretamente pelo Poder Legislativo, pelo Tribunal de Contas, em auxílio ao Poder Legislativo e pelo Poder Judiciário, por meio do controle jurisdicional.

Embora o controle jurisdicional tenha extrema relevância no regime democrático vigente, a atuação do Poder Judiciário deve ser impulsionada pelo interessado, inclusive o Ministério Público. Celso Antônio Bandeira de Melo (2009, p. 926) considera que "dentre todos os controles o mais importante, evidentemente, é o que se efetua, a pedido dos interessados, por meio do Poder Judiciário".

Para Hely Lopes Meirelles (2009, p. 715-716), “controle judiciário ou judicial é o exercido privativamente pelos órgãos do Poder Judiciário sobre os atos administrativos do Executivo, do Legislativo e do próprio Judiciário quando realiza atividade administrativa”. Trata-se de importante meio de preservação dos direitos individuais ou coletivos, pois é o mecanismo judicial de correção de eventuais desvios ou de preservação de direitos. No entanto, a análise desses aspectos não está no objeto deste trabalho.

Pelo modelo institucional construído a partir da Constituição Federal de 1988, o Ministério Público possui importante papel no controle da Administração. Nessa mesma linha, Marcus Vinicius Rios Gonçalves (2009, p. 207) descreve que a CF incluiu o Ministério Público entre os órgãos que exercem funções essenciais à justiça. Para o autor, "O art. 127 atribui a ele a defesa da ordem jurídica, do regime democrático e dos interesses sociais e individuais indisponíveis".

Aspecto importante das competências do Ministério Público é a prevista no artigo 129, inciso III, da Constituição Federal, que atribui legitimidade para a 
propositura de ação civil pública para a proteção do patrimônio público e social, do meio ambiente e de outros interesses difusos e coletivos ${ }^{169}$.

Em relação à atividade de controle externo, a atuação do Ministério Público junto aos Tribunais de Contas é de extrema relevância. Embora a Constituição Federal não tenha especificado que tal atividade fosse exercida por instituição própria, mas tão somente dispôs sobre membros do Ministério Público junto aos Tribunais de Contas, o certo é que o Supremo Tribunal Federal teve entendimento de que deve haver um “Ministério Público especial junto às Cortes de Contas, ainda que sem a mesma autonomia institucional dos demais Ministérios Públicos, pois 'integra a organização administrativa do Tribunal de Contas da União, ainda que privilegiado por regime jurídico especial" (Hugo Nigro Mazzilli, 2008, p. 81)”. Para Hugo Mazzilli (2008, p. 81), “os membros do Ministério Público junto aos Tribunais de Contas têm atuação restrita a esses tribunais, dando pareceres e oficiando como custos legis nos procedimentos e processos respectivos".

Ainda com fundamento na lição de Hugo Mazzilli (2009, p. 75-81), cabe relacionar uma série de medidas judiciais e administrativas que podem ser propostas pelo Ministério Público na defesa da res publica: 1) ação civil pública para a proteção do patrimônio público (art. 129, III); 2) ação de sequestro e de perda de bens na defesa do patrimônio público (Lei n. 8.429/92, arts $7^{\circ}$ e 16); 3) ação de reparação de danos em defesa do patrimônio público (Lei n. 8.429/91, arts 17 e 19); 4) ação para responsabilização do agente público ou de terceiros, em decorrência de decisões do Tribunal de Contas da União (Lei n. 8.443/92, art. $16, \S 3^{\circ}$ ); 5) ação para declaração de nulidade de atos ou contratos geradores do endividamento externo de ente público (LC n. 75/93, art. 6º XVII, b); 6) ação de defesa da ordem financeira (Lei n. 8.884/94, art. 12, parágrafo único; LC n. 75/93, art. $6^{\circ}$, XIV, b) e 7) ação para defesa de interesses difusos ou coletivos decorrentes de responsabilidade por danos patrimoniais e morais causados por infração da ordem econômica (Lei n. 8.884/94, art. 88), entre outras.

Conclui-se, portanto, que, no campo da defesa da res publica e do fortalecimento dos instrumentos de governança republicana, o Ministério Público tem legitimidade para atuar na defesa da boa gestão financeira por parte da Administração

\footnotetext{
${ }^{169}$ Cf. Marcus Vinicius Rios Gonçalves (GONÇALVES, Marcus Vinicius Rios. Novo curso de direito processual civil. São Paulo: Saraiva, 2009. p. 212) que afirma: "toda vez que ficar evidenciada a existência de interesse público - que não se confunde com interesse do Estado ou da Fazenda Pública - o juiz determinará a abertura de vista ao Ministério Público".
} 
Pública. Hugo Nigro Mazzilli (2009, p. 139) defende que "como a Emenda Constitucional n. 19/98 incluiu a eficiência entre os princípios da Administração Pública, se houver desvio dessa meta, sujeita-se o administrador a controle até mesmo jurisdicional". Nesse raciocínio, cabe controle externo e atuação do Ministério Público quando houver desvio dos princípios que regem a Administração, inclusive os princípios da eficiência e da moralidade, uma vez que o afastamento da gestão pública desse princípio compromete o patrimônio público e, consequentemente, o interesse público ${ }^{170}$.

Além disso, Hugo Nigro Mazzilli (2009, p. 193) leciona que "quaisquer atos de improbidade administrativa podem ser objetivo de investigação por parte do Ministério Público ${ }^{171}$, ou seja, tanto os que importem enriquecimento ilícito de agentes públicos, como os que provoquem lesão ao erário, como, enfim, os que atentem contra os princípios da administração (artigos $9^{\circ}$ a 11 da Lei n. 8.429/92) ${ }^{172}$."

\footnotetext{
${ }^{170}$ Hugo Nigro Mazzilli (MAZZILLI, Hugo Nigro. A defesa dos interesses difusos em juízo. São Paulo: Saraiva, 2009. p. 192) indica um exemplo de quebra do princípio da moralidade: "a previdência nacional existe, teoricamente, para prestar ou pagar benefícios previdenciários a partir de seu custeio atuarial. Mas se ela se transforma numa máquina de arrecadar dinheiro, financiar o governo e só pagar miseravelmente os supostos benefícios apenas depois de esgotar os meios de furtar-se à sua obrigação, então teremos a imoralidade administrativa implantada no sistema. $\mathrm{O}$ aposentado, principalmente se pobre, bate-se contra uma verdadeira muralha quando quer buscar seus benefícios: se o sistema cria todas as dificuldades para uma pessoa se aposentar mesmo que tenha esse direito, e se o sistema cria absurdas exigências para the conceder o benefício mesmo quando devido, isso será imoralidade administrativa. Não se trata de uma questão de hipotética moralidade 'jurídica' ou 'moralidade abstrata ou média'."

${ }^{171}$ Celso Antônio Bandeira de Melo (MELLO, Celso Antônio Bandeira de. op. cit., p. 928) também consigna que "de transcendente importância é a Lei 8.429, de 2.6.92, a qual arrola uma cópia de comportamentos qualificados como de 'improbidade administrativa', cuja prática sujeita o agente, de, fora parte sanções penais, civis ou administrativas, contempladas na legislação competente, a uma série de consequências gravosas previstas em seu art. 12, tais as de: ressarcimento integral do dano se houver; perda de função pública; suspensão dos direitos políticos; multa civil e proibição, por tempo determinado, de contratar com o Poder Público ou receber benefícios ou incentivos fiscais ou creditícios, direta ou indiretamente, ainda que por intermédio de pessoa jurídica da qual seja sócio majoritário. Qualquer pessoa pode representar à autoridade administrativa competente para que seja instaurada investigação destinada à apuração de tais ilícitos, sem prejuízo de representar também ao Ministério Público (arts. 14 e 22)".

${ }^{172}$ Hugo Nigro Mazzilli (MAZZILLI, Hugo Nigro. op. cit., p. 196-197) relata que, "quanto à segunda categoria de atos sancionados na Lei n. 8.429/92, considera esta constituir improbidade administrativa que causa lesão ao erário, qualquer ação ou omissão, dolosa ou culposa, que enseje perda patrimonial, desvio, apropriação, malbaratamento ou dilapidação dos bens ou haveres das entidades referidas no art. $1^{\circ}$ da Lei $n$. 8.429/92, e, notadamente:

1. Facilitar ou concorrer por qualquer forma para a incorporação ao patrimônio particular, de pessoa física ou jurídica, de bens, rendas, verbas ou valores integrantes do acervo patrimonial das entidades mencionadas no art. $1^{\text {o; }}$

2. Permitir ou concorrer para que pessoa física ou jurídica privada utilize bens, rendas, verbas ou valores integrantes do acervo patrimonial das entidades mencionadas no art. $1^{\circ}$, sem a observância das formalidades legais ou regulamentares aplicáveis à espécie;

3. Doar à pessoa física ou jurídica bem como ao ente despersonalizado, ainda que de fins educativos ou assistenciais, bens, rendas, verbas ou valores do patrimônio de qualquer das entidades mencionadas no art. $1^{\circ}$, sem a observância das formalidades legais e regulamentares aplicáveis à espécie;

4. Permitir ou facilitar a alienação, permuta ou locação de bem integrante do patrimônio de qualquer das entidades referidas no art. $1^{\circ}$, ou ainda a prestação de serviço por parte delas, por preço inferior ao de mercado;
} 
Para Hugo Nigro Mazzilli (2009, p. 215),

[...] a atuação do Ministério Público em defesa do patrimônio público deve mesmo ocorrer, mas deve ser exercida de forma responsável, seja porque sua legitimação é excepcional, porque extraordinária, seja porque, se não for preciso e adequado na sua ação, ao cometer erros, abusos ou injustiças, verá crescer contra ele as iniciativas de cercear-se sua atuação funcional. Entretanto, quando o sistema de legitimação ordinária falhar, não há outro caminho efetivo a não ser a ação responsável do Ministério Público, que deverá propor perante o Poder Judiciário as ações que a Constituição e as leis puseram em suas mãos ${ }^{173}$.

Já o controle externo realizado pelo Poder Legislativo tem duas vertentes: uma de caráter político, realizada diretamente pela atuação parlamentar e outra técnica, com auxílio do Tribunal de Contas ${ }^{174}$.

Para José Afonso da Silva (2008, p. 753), a fiscalização externa realizada pelo Poder Legislativo "É, portanto, um controle de natureza política, no Brasil, mas sujeito à prévia apreciação técnico-administrativa do Tribunal de Contas competente, que, assim, se apresenta como órgão técnico [...]. No mesmo sentido, Hely Lopes Meirelles (2009, p. 713) entende que o controle externo "É, por excelência, um controle político de legalidade contábil e financeira, o primeiro aspecto a cargo do Legislativo; o segundo do Tribunal de Contas".

5. Permitir ou facilitar a aquisição, permuta ou locação de bem ou serviço por preço superior ao de mercado;

6. Realizar operação financeira sem observância das normas legais e regulamentares ou aceitar garantia insuficiente ou inidônea;

7. Conceder benefício administrativo ou fiscal sem a observância das formalidades legais e regulamentares aplicáveis à espécie;

8. Frustrar a licitude de processo licitatório ou dispensá-lo indevidamente;

9. Ordenar ou permitir a realização de despesas não autorizadas em lei ou regulamento;

10. Agir negligentemente na arrecadação de tributo ou renda, bem como no que diz respeito à conservação do patrimônio público;

11. Liberar verba pública sem a estrita observância das normas pertinentes ou influir de qualquer forma para a sua aplicação irregular;

12. Permitir, facilitar ou concorrer para que terceiro se enriqueça ilicitamente;

13. Permitir que se utilize, em obra ou serviço particular, veículos, máquinas, equipamentos ou material de qualquer natureza, de propriedade ou à disposição de qualquer da entidades mencionadas no art. $1^{\circ}$, bem como o trabalho de servidor público empregados ou terceiros contratados por essas entidades."

${ }^{173}$ Hugo Nigro Mazzilli (MAZZILLI, Hugo Nigro. op. cit., p. 215) relata que, "enfim, após bastante controvérsia, embora sem maior razão à vista do claro mandamento constitucional (CR, art. 129, III), os tribunais mais recentemente têm passado a admitir a legitimidade do Ministério Público para a defesa do patrimônio público, por meio da ação civil pública."

Súmula 329 do STJ: "O Ministério Público tem legitimidade para propor ação civil pública em defesa do patrimônio público". O STF também assim entende.

${ }^{174}$ Cf. ZYMLER, Benjamin. op. cit., p. 22. 
Dada a relevância e a proximidade da fiscalização externa realizada pelos Tribunais de Contas, o tema passa a ser analisado no item seguinte.

\subsubsection{O controle externo realizado pelos Tribunais de Contas}

O Tribunal de Contas desempenha a função constitucional de dar auxílio ao Congresso Nacional no exercício de seu mister de controle da "Administração direta e indireta, exercendo fiscalização contábil, financeira, orçamentária, patrimonial e operacional, quanto à legalidade, legitimidade, economicidade, aplicação das subvenções e renúncias de receitas" (art. $70, \mathrm{CF})^{175}$. A Corte de Contas, portanto, possui atribuições amplíssimas. ${ }^{176}$

${ }^{175}$ Os Tribunais de Contas têm competência para (art. 71 e incisos):

a) apreciar as contas prestadas anualmente pelo Presidente da República, mediante parecer prévio que deverá ser elaborado em sessenta dias a contar do seu recebimento. As contas do Presidente são os documentos relativos à gestão que este é obrigado a exigir (balanços, demonstrativos e anexos, nos termos do art. 191 da Lei 4.320/64). Mas, além destes, para cuja análise concorrem os aspectos formais, são também documentos "que concernem aos atos ou indevidas omissões próprios e específicos do Chefe do Poder Executivo, de responsabilidade pessoal dele, vale dizer, que lhe sejam direta e pessoalmente imputáveis e que, estas sim, terão de passar por um crivo substancial. Por isto, é curto o prazo de que dispõe o Tribunal de Contas para apreciá-las".

b) julgar as contas dos administradores e demais responsáveis por dinheiros, bens e valores públicos da administração direta e indireta, incluídas as fundações e sociedades instituídas e mantidas pelo Poder Público federal, e as contas daqueles que derem causa a perda, extravio ou outra irregularidade de que resulte prejuízo ao erário público;

c) apreciar, para fins de registro, a legalidade dos atos de admissão de pessoal, a qualquer título, na administração direta e indireta, incluídas as fundações instituídas e mantidas pelo Poder Público, excetuadas as nomeações para cargo de provimento em comissão, bem como a das concessões de aposentadorias, reformas e pensões, ressalvadas as melhorias posteriores que não alterem o fundamento legal do ato concessório;

d) realizar, por iniciativa própria, da Câmara dos Deputados, do Senado Federal, de Comissão técnica ou de inquérito, inspeções e auditorias de natureza contábil, financeira, orçamentária, operacional e patrimonial, nas unidades administrativas dos Poderes Legislativo, Executivo e Judiciário, e demais entidades referidas no inciso II;

e) fiscalizar as contas nacionais das empresas supranacionais de cujo capital social a União participe, de forma direta ou indireta, nos termos do tratado constitutivo;

f) fiscalizar a aplicação de quaisquer recursos repassados pela União mediante convênio, acordo, ajuste ou outros instrumentos congêneres, a Estado, ao Distrito Federal ou a Município;

g) prestar as informações solicitadas pelo Congresso Nacional, por qualquer de suas Casas, ou por qualquer das respectivas Comissões, sobre a fiscalização contábil, financeira, orçamentária, operacional e patrimonial e sobre resultados de auditorias e inspeções realizadas;

h) aplicar aos responsáveis, em caso de ilegalidade de despesa ou irregularidade de contas, as sanções previstas em lei, que estabelecerá, entre outras cominações, multa proporcional ao dano causado ao erário;

i) assinar prazo para que o órgão ou entidade adote as providências necessárias ao exato cumprimento da lei, se verificada ilegalidade;

j) sustar, se não atendido, a execução do ato impugnado, comunicando a decisão à Câmara dos Deputados e ao Senado Federal;

k) representar ao Poder competente sobre irregularidades ou abusos apurados.

${ }^{176}$ Cf. MELLO, Celso Antônio Bandeira de. op. cit., p. 933. 
Ao analisar dados históricos do controle de contas, Hélio Mileski (2003, p. 177-178) conclui haver uma classificação que melhor apresenta os organismos de controle do Estado Moderno. Este controle, historicamente, ou é feito de forma individual (sistema de controladoria) ou de maneira colegiada (sistema de Tribunais de Contas). Ambos têm origem europeia e influenciaram suas colônias. O Tribunal de Contas predomina em países latinos, de influência francesa e portuguesa, ao passo que a controladoria predomina nos sistemas de controle que seguem a tradição inglesa.

$\mathrm{Na}$ Inglaterra, cujo exemplo é sempre citado no que se refere ao controle e à limitação do Poder por razões históricas, surgiu a fiscalização financeira do governo por meio do Comptroller General of the Receipt and Issue of His Majesty's Exchequer ${ }^{177}$.

Também nos Estados Unidos adota-se o sistema de controladoria. O controle é exercido pelo Congresso, auxiliado por uma Comissão de Fiscalização denominada General Accounting Office - GAO, que, conforme afirma Hélio Mileski (2003, p. 178), “dispõe de poderes para se opor à ação administrativa, mediante apreciação do mérito e da legalidade da despesa a ser efetuada, cuja direção é exercida pelo Comptroller-general, o Controlador-Geral, nomeado pelo Presidente americano, mediante aprovação do Senado".

Na Austrália existe o ANAO - Australian National Audit Office que presta serviços de auditoria para o Parlamento australiano e entidades do setor público. Dá, assim, suporte técnico ao Auditor Geral, que é um funcionário independente do Parlamento. Trata-se de uma instituição já com mais de 100 anos (foi criada em 1901) e reformada pelo Audit General Act, de 1997, que fortaleceu as competências da instituição. $^{178}$

O sistema de Tribunal de Contas, porém, é um sistema diferente, por ser colegiado. Assim que na França, mesmo com uma filosofia absolutista de Estado, o

\footnotetext{
${ }^{177}$ Neste sistema de fiscalização, segundo Alfredo Cecílio Lopes (LOPES, Alfredo Cecílio. Ensaio sobre o Tribunal de Contas. São Paulo, 1947. p. 55), “o contrasteamento constitucional distingue-se do administrativo, confiado a um 'Paymaster-General', pagador-geral, incumbido de organizar a sua escrituração pelo método das partidas dobradas, tanto em relação às contas gerais como às auxiliares ou elementares. A fiscalização judiciária está entregue ao 'Auditor General', o qual, pelo 'Exchequer and Audit Acto of 1866', que consolidou e modernizou as velhas leis e costumes da atividade financeira, se é um órgão distinto do 'Comptroller', é exercido pela mesma pessoa. Suas funções são as de fiscalizar o bom emprego dos dinheiros públicos e apurar as responsabilidades dos funcionários que agirem em detrimento dos interesses do tesouro."

${ }^{178}$ As informações podem ser verificadas no sítio da instituição, HISTORY of the Anao. Disponível: em: $<$ ttp://www.anao.gov.au/director/aboutus/history.cfm>.
} 
monarca contava com um sistema requintado de escrituração das contas reais (o método das partidas dobradas), desde Luiz IX. Com este rei estabeleceram-se, em 1256, normas rígidas de gestão financeira do reino, o que é por muitos considerada a criação de uma verdadeira Corte de Contas. ${ }^{179}$ Mas foi Felipe IV, o Belo, que, em 1309, instituiu a Chambre de Comptes. O instituto evoluiu até que, em 16 de setembro de 1807, Napoleão criou a Cour des Comptes, composta de sete membros, escolhidos pelo Senado, cuja estrutura permanece ainda hoje e é o sistema que prevalece em diversos países, como o Brasil. $^{180}$

A doutrina ${ }^{181}$ aponta três tipos fundamentais de Tribunais de Contas: o francês, o belga e o italiano.

O sistema francês assenta-se, conforme Batista Ramos (1980, p. 194), "numa Corte de Contas (ou Câmara de Contas), tribunal independente de grande prestígio, com funções de caráter jurisdicional, mas isso não significa inexistência de um controle interno dos órgãos administrativos e de outro, final, realizado pelo parlamento." A fiscalização exercida pela Corte de Contas francesa é a posteriori, com atribuições tanto administrativas como jurisdicionais.

O sistema belga sofreu influência do francês, mas inovou substancialmente o sistema de fiscalização jurisdicional, já que a Lei Orgânica de 21 de junho de 1820, "regulamentando a Câmara de Contas dos Países Baixos, estabelecera que nenhum pagamento do Estado poderia ser feito, se a despesa não fosse previamente verificada e liquidada pela Câmara de Contas, reservada ao poder real, entretanto, a faculdade ilimitada de autorizar pagamentos provisórios, ou adiantamentos", conforme relata Alfredo Cecílio Lopes (1947, p. 181).

Também o sistema italiano tem influência francesa, mas a Corte dei Conti envolve três funções: de controle, jurisdicional e administrativa. Sua jurisdição se aplica às matérias de contabilidade pública e em outras especificadas em lei.

De fato, órgãos de controle com composição colegiada, como o Tribunal de Contas brasileiro, existem em Portugal, na Espanha, Itália, Alemanha e França. Insta,

\footnotetext{
${ }^{179}$ Cf. MILESKI, Helio Saul. op. cit., p. 179 e LOPES, Alfredo Cecílio. op. cit., p. 38.

${ }^{180}$ Cf. MILESKI, Helio Saul. op. cit., p. 179.

${ }^{181}$ Cf. GUALAZZI, Eduardo Lobo Botelho. Regime jurídico dos Tribunais de Contas. São Paulo: Ed. Revista dos Tribunais, 1992. p. 59.
} 
ainda, mencionar a existência da INTOSAI - International Organization os Supreme Audit Institutions, órgão vinculado à Organização das Nações Unidas - ONU, com sede em Viena e com o objetivo de promover a troca, entre as instituições afiliadas, de experiências na área de auditoria e fiscalização, ao qual o Brasil é filiado.

A exemplo desta instituição, foram criadas diversas organizações internacionais que congregam instituições de fiscalização e auditoria de diversos países, em âmbito continental ou regional, tais como AFROSAI (países africanos), ASOSAI (países asiáticos), ARABOSAI (países árabes), CAROSAI (países do Caribe), EUROSAI (países europeus), OLACEFS (países da América Latina e do Caribe) e SPASAI (países do Pacífico Sul) ${ }^{182}$.

Na América Latina, possuem Tribunais de Contas apenas o Brasil e o Uruguai. Outros países possuem controladorias, em alguns casos vinculadas ao Poder Legislativo e, em outros, ao Executivo; como exemplo, pode-se citar Argentina, Equador, México, Venezuela, Paraguai, Bolívia, Colômbia, Peru e Chile ${ }^{183}$.

No Brasil, até a proclamação da República era precária a fiscalização da atividade financeira do Estado. Algumas medidas de natureza político-administrativas foram tomadas desde a época da colônia, entretanto. Assim, relata José Leonardo Andriolo (2000, p. 195) que

[...] a oficialização do Vice-Reino do Brasil, em 1720, foi uma das medidas tomadas para exercer maior fiscalização sobre as finanças da Colônia, haja vista que o controle exercido por Portugal era bastante precário. Com a chegada da família real ao Rio de Janeiro, no dia 7 de março de 1808, o Brasil passava de simples colônia à condição de sede do governo português, sendo organizados os serviços de governo e administração, sendo criado, também, o Erário Régio, responsável pela guarda dos tesouros reais. Na mesma época, foi instituído o Conselho da Fazenda, a quem coube o controle dos gastos públicos, embora operasse de maneira ineficaz, devido à desorganização financeira do país e aos saques da nobreza lusitana ao Erário.

À época do Império, ilustres juristas como Pimenta Bueno, em 1857, e José de Alencar, em 1861, defenderam a criação de um Tribunal de Contas no país. O primeiro o exigiu como condição de ser assegurada a correta aplicação dos recursos públicos. Em discurso na Câmara dos Deputados, José de Alencar defendeu que se criasse

\footnotetext{
${ }^{182}$ Cf DECOMAIN, Pedro Roberto. Tribunais de Contas no Brasil. São Paulo: Dialética, 2006.

${ }^{183}$ Cf. FERNANDES, Jorge Ulisses Jacoby. Tribunais de Contas no Brasil: jurisdição e competência. Belo Horizonte: Fórum, 2003.
} 
uma Corte de Contas, no que foi seguido pelo Ministro da Fazenda Gaspar Silveira Martins, em 1878, em relatório ao Poder Legislativo. Outros ministros desta pasta, como o Visconde de Ouro Preto, em 1879, e o último do Império, João Alfredo, em 1889, também o fizeram. Anteriormente, a ideia já fora proposta ao Congresso em 1826, pelos Senadores Visconde de Barbacena e José Inácio Borges, em 1826, e por Manoel Alves Branco, em 1845. O Império passou suas quase sete décadas, porém, sem um órgão de controle das contas públicas. ${ }^{184}$

De qualquer forma, embora a origem dos Tribunais de Contas remonte aos primórdios da República, a Constituição brasileira de 1824 já continha, em seu texto, normas de administração financeira e a disposição de que incumbia a um tribunal, denominado Thesouro Nacional, a realização de receitas e despesas do Império. Todavia, a este "tribunal" competia atuação executiva e não o controle da realização de receitas e despesas.

A criação do Tribunal de Contas no Brasil, como órgão fiscalizador, deuse com o decreto $\mathrm{n}^{\circ}$ 966-A, de 07.11.1890, de iniciativa de Ruy Barbosa, inspirado no Tribunal de Contas italiano ${ }^{185}$ e pela Constituição de $1891^{186}$. Na Constituição de 1934, a competência do Tribunal de Contas brasileiro aproximou-se ainda mais do italiano ao se prever a necessidade de registro prévio junto ao Tribunal de quaisquer contratos que interessassem à receita ou à despesa nacional, sob pena de suspensão da execução do referido contrato, função esta extinta pouco depois, com a Constituição de 1937.

A Constituição de 1946, por sua vez, ampliou novamente o rol de atribuições do Tribunal de Contas, a quem caberia: acompanhar e fiscalizar diretamente, ou por delegações criadas em lei, a execução do orçamento; julgar as contas dos responsáveis por dinheiros e outros bens públicos, e as dos administradores das entidades autárquicas; julgar da legalidade dos contratos e das aposentadorias, reformas e pensões. Ademais, os contratos que, por qualquer modo, interessassem à receita ou à despesa só se reputariam perfeitos depois de registrados pelo Tribunal de Contas. A recusa do registro suspenderia a execução do contrato até que se pronunciasse o Congresso Nacional. Qualquer ato da Administração Pública de que resultasse obrigação de pagamento ao Tesouro deveria ser

\footnotetext{
${ }^{184}$ Cf. LOPES, Alfredo Cecílio. op. cit., p. 214-217; José Afonso da Silva (SILVA, José Afonso da. Curso de direito constitucional positivo, cit., p. 752-754).

${ }^{185}$ Cf. DECOMAIN, Pedro Roberto. op. cit.

${ }^{186}$ Constituição de 1891 assim dispôs: "É instituído um Tribunal de Contas para liquidar as contas da receita e despesa e verificar a sua legalidade, antes de serem prestadas ao Congresso".
} 
sujeito ao registro prévio ou posterior no Tribunal de Contas. As Contas que o Presidente da República devesse anualmente prestar ao Congresso Nacional deveriam ser objeto de um relatório prévio do Tribunal de Contas (art. 77, Constituição de 1946).

A Constituição de 1967 reduziu substancialmente estes poderes, que foram novamente recuperados com a atual Constituição de 1988. É que os Tribunais de Contas sempre acompanham o que acontece ao Poder Legislativo, como se manifesta José Afonso da Silva (2008, p. 753). Se este perde suas atribuições básicas, isto também se passa com seu órgão auxiliar de controle. Porém, o Tribunal de Contas manteve a competência para apresentação de parecer às contas do Presidente da República, antes de sua apreciação pelo Congresso Nacional, bem como de julgar as contas dos responsáveis por dinheiros e outros bens públicos. Não obstante, a Carta permitiu que o Tribunal de Contas sustasse a execução de atos em que verificasse ilegalidade se esta não fosse sanada no prazo assinalado aos responsáveis.

No que concerne a contratos, a competência do Tribunal de Contas resumia-se apenas a solicitar ao Congresso Nacional que determinasse a sustação de sua execução ou adotasse as providências que entendesse adequadas. Em caso de determinação da suspensão de atos não contratuais, o Presidente da República poderia ordenar sua execução, ad referendum do Congresso Nacional.

Tais funções foram mantidas com a Emenda Constitucional $\mathrm{n}^{\circ} 01$, de 1969. Naquela oportunidade, contudo, foi prevista a criação de Tribunais de Contas pelos Estados-membros da Federação. A criação de tais órgãos não foi expressamente determinada no texto constitucional, mas aparecia implícita quanto ao auxílio dos Tribunais de Contas estaduais no controle externo das contas públicas municipais ${ }^{187}$. Em que pese a previsão constitucional tenha surgido apenas em 1969, alguns Estados já haviam criado seus Tribunais de Contas anteriormente, mesmo sem permissão da Constituição de $1946^{188}$. Na ocasião, também foi permitida a criação de Tribunais de

\footnotetext{
${ }^{187}$ Neste sentido, Pedro Roberto Decomain (DECOMAIN, Pedro Roberto. op. cit.) afirma que "A grande novidade da Emenda Constitucional n ${ }^{\circ}$ 1, de 1969, em tema de Tribunais de Contas, reside na previsão de que fossem criados pelos Estados. De acordo com seu art. 13, inciso IX, deveriam aplicar-se aos membros dos Tribunais de Contas dos Estados as regras dos incisos I a III, do art. 114 da mesma Emenda Constitucional. Não havia, na Emenda, a previsão expressa da criação dos Tribunais de Contas dos Estados, mas essa referência significava a consagração implícita da necessidade de que existissem, contendo também um disciplinamento mínimo do estatuto de seus componentes, cujo número, de acordo com o mesmo dispositivo, não poderia exceder a sete".

${ }^{188}$ Cf. CRETELLA JÚNIOR, José. Curso de direito administrativo. 18. ed. Rio de Janeiro: Forense, 2003.
} 
Contas nos municípios que tivessem população e arrecadação tributária mínimas, respectivamente, de dois milhões de habitantes e quinhentos milhões de cruzeiros novos.

A Constituição Federal Brasileira de 1988 prevê, em seus artigos 71 a 73, o controle externo da Administração Pública mediante fiscalização contábil, orçamentária, financeira, operacional e patrimonial, e estabelece como responsáveis por esta fiscalização os Tribunais de Contas, nos âmbitos federal e estadual, na qualidade de órgãos auxiliares e de orientação ao Poder Legislativo, embora a ele não subordinados.

Em sua atuação, conforme disposição da Carta Constitucional de 1988, os Tribunais de Contas são responsáveis (i) pela fiscalização financeira dos atos que importem receita ou despesa à Administração Pública, (ii) pela apresentação de parecer prévio sobre as contas prestadas anualmente pelo chefe do Poder Executivo, (iii) por prestar informações ao Poder Legislativo, na qualidade de seu auxiliar, pelo julgamento de contas de administradores e demais responsáveis por dinheiros, bens e valores públicos e daqueles que derem causa à perda, extravio ou outra irregularidade que cause prejuízo ao erário, (iv) pela aplicação das sanções cabíveis aos responsáveis por ilegalidade de despesas ou irregularidade de contas, (v) pela determinação de prazo para que o órgão fiscalizado adote providências para sanar eventual irregularidade, sob pena de sustar a execução de referido ato e (vi) por receber denúncias de irregularidades e ilegalidades praticadas no seio do Poder Público ${ }^{189}$.

Com relação à sua composição, trata-se, o Tribunal de Contas, de órgão composto de nove membros, com mais de 35 e menos de 65 anos de idade, idoneidade moral e reputação ilibada. É também requisito de investidura dispor de notórios conhecimentos jurídicos ou contábeis, econômicos, financeiros ou de administração pública, além de contar com mais de dez anos de exercício de função ou efetiva atividade profissional exigente da espécie de conhecimentos referidos (art. 73 e $\S 1^{\circ}$ ). Os titulares do cargo têm as mesmas garantias, prerrogativas, impedimentos, vencimentos e vantagens dos Ministros do Superior Tribunal de Justiça (art. 73, $\S 3^{\circ}$ ).

A nomeação de um terço dos membros é feita pelo Presidente da República, sob aprovação do Senado Federal, dentre os nomes constantes de lista tríplice composta pelo próprio Tribunal e integrada por auditores e membros do Ministério Público

\footnotetext{
${ }^{189}$ Maria Sylvia Di Pietro (DI PIETRO, Maria Sylvia Zanella. op. cit.) elenca tais atribuições como funções de fiscalização financeira, consulta, informação, julgamento, sancionatórias, corretivas e de ouvidor.
} 
junto ao Tribunal, escolhidos na conformidade de critérios de antiguidade e merecimento. Os outros dois terços são designados pelo Congresso Nacional $\left(\operatorname{art.} 73, \S 2^{\circ}\right.$ ).

No exercício de suas funções, o Tribunal de Contas é competente para apreciar a constitucionalidade das leis ou dos atos da Administração Pública, consoante reconhece o Supremo Tribunal Federal, na súmula $347^{190}$.

Em que pese a ampliação significativa da esfera de competência dos Tribunais de Contas no Brasil, a Constituição Federal de 1988 vedou a criação de Tribunais ou Conselhos de Contas municipais, em seu artigo 31, $\S 4^{\circ}$. Esta disposição, analisada em conjunto com o artigo 75 da Carta Magna, implica o reconhecimento que, embora haja vedação expressa quanto à criação de novos Tribunais de Contas municipais, a Constituição permite que os Tribunais existentes até sua entrada em vigor permaneçam em atividade, não determinando, assim, sua abolição ${ }^{191}$.

Muito embora a posição dos tribunais de contas na estrutura do Estado já tenha sido objeto de reflexão ${ }^{192}$, o certo é que sua configuração encontra fundamento na Constituição Federal.

É necessário observar como o texto constitucional trata do tema. E na Constituição, apesar do art. 73 da Constituição aplicar ao Tribunal de Contas as atribuições judiciais previstas no art. 96, ele não é mencionado como órgão do Poder Judiciário. Estas atribuições referem-se ao poder de eleger seus órgãos diretivos e elaborar seu próprio regimento interno, além de organizar seus serviços, prover os seus cargos e propor a criação e a extinção de cargos e a remuneração de seus membros e serviços auxiliares. Por outro lado, a visão de que o Tribunal de Contas constitui um quarto poder ${ }^{193}$ não encontra absolutamente nenhum respaldo constitucional ${ }^{194}$. Deveras, a Constituição Federal diz

\footnotetext{
190“ $O$ Tribunal de Contas, no exercício de suas atribuições, pode apreciar a constitucionalidade das leis e dos atos do Poder Público”.

${ }^{191}$ Neste sentido, DECOMAIN, Pedro Roberto. op. cit.

${ }^{192}$ O Conselheiro Anhaia Mello manifestou-se no seguinte sentido: “(...) me encanta a idéia de um Tribunal de Contas inserido na órbita do Poder Judiciário, como uma Justiça Especial, a par da eleitoral, da trabalhista, da agrária, como uma Justiça de Contas", exibindo predileção por sua colocação na órbita do Poder Judiciário (CITADINI, Antônio Roque. O controle externo da administração pública. São Paulo: Max Limonad, 1995. p. 24). Por sua vez, Pontes de Miranda (MIRANDA, Pontes de. Comentários à Constituição de 1967, com a Emenda n. 1, de 1969. 2. ed. rev. São Paulo: Ed. Revista dos Tribunais, 1970. p. 249), pondera que "o texto constitucional de 1967 pôs no Poder Legislativo o Tribunal de Contas". Para sua definição como um quarto poder, ver COSTA, Sylo. O quarto poder. Revista do Tribunal de Contas do Estado de Minas Gerais, ano 25, v. 4, p. 45-64, out./dez. 1997.

${ }^{193}$ Cf. COSTA, Sylo. op. cit.

${ }^{194}$ Helio Saul Mileski (MILESKI, Helio Saul. op. cit., p. 203) defende que "a teoria de que o Tribunal de Contas constitui um $4^{\circ}$ Poder retrata mais uma vontade de que assim se proceda do que uma possibilidade
} 
expressamente quais são os Poderes do Estado em seu art. $2^{\circ}$ : são Poderes da União, independentes e harmônicos entre si, o Legislativo, o Executivo e o Judiciário.

$\mathrm{O}$ art. 71 da Carta Magna é vazado com o seguinte teor: "o controle externo, a cargo do Congresso Nacional, será exercido com o auxílio do Tribunal de Contas da União (...)". Desta forma, como a maior parte da doutrina brasileira expressa, o Tribunal de Contas é um órgão que auxilia o Poder Legislativo, embora o referido artigo constitucional, em certa medida, enseje interpretações errôneas de que há um sentido de subordinação entre o órgão de controle de contas e o Poder Legislativo. Trata-se de um órgão autônomo que presta auxílio, e não de um órgão auxiliar hierarquicamente subordinado àquele Poder ${ }^{195}$.

Ricardo Lobo Torres (2000, p. 487) faz a seguinte ponderação:

O Tribunal de Contas, a nosso ver, é órgão auxiliar dos Poderes Legislativo, Executivo e Judiciário, bem como da comunidade e de seus órgãos de participação política: auxilia o Legislativo no controle externo, fornecendo-lhe informações, pareceres e relatórios; auxilia a Administração e o Judiciário na autotutela da legalidade e no controle interno, orientando a sua ação e controlando os responsáveis por bens e valores públicos.

Ainda em relação à peculiar posição do Tribunal de Contas na estrutura do Estado, não é ele um órgão que exerce função legislativa formal, já que seus atos não têm eficácia genérica de lei. De outra banda, é mais difícil, porém, a questão da sua função jurisdicional, levando àquilo que Pontes de Miranda (1970, p. 254) identificou como uma "função judicialforme do Tribunal de Contas". Em sentido material, este órgão exerce atos típicos da função jurisdicional, pois que, consoante entendimento de Ricardo Lobo Torres (2000, p. 489), “julga as contas dos administradores e responsáveis com todos os requisitos

constitucional de assim se entender. Embora seja muito interessante e seduza-me a idéia de ser criado um $4^{\circ}$ Poder, intitulado Poder Fiscalizador, constituído de dois organismos, o Ministério Público e o Tribunal de Contas, um como fiscal da lei e defensor da ordem jurídica, do regime democrático e dos interesses sociais e individuais indisponíveis e outro como fiscal da atividade financeira do Estado, cuja ação ocorre em nome do interesse coletivo, inexiste espaço constitucional e muito menos convencimento nacional, em nível técnico, jurídico e político, para tal idéia ser concretizada".

${ }^{195}$ Cf. Odete Medauar (MEDAUAR, Odete. Controle da administração pública pelo Tribunal de Contas. Revista Informação Legislativa, Brasília, ano 27, n. 108, p. 124, out./dez. 1990), para quem é "muito comum é a menção do Tribunal de Contas como órgão auxiliar do Poder Legislativo, o que acarreta ideia de subordinação. Confunde-se, desse modo, a função com a natureza do órgão. A Constituição Federal, em artigo algum, utiliza a expressão 'órgão auxiliar'; dispõe que o controle externo do Congresso Nacional será exercido com o auxílio do Tribunal de Contas; a sua função, portanto, é de exercer o controle financeiro e orçamentário da Administração em auxílio do poder responsável, em última instância, por esta fiscalização (...). Se a sua função é atuar em auxílio ao Legislativo, a sua natureza, em razão das próprias normas da Constituição, é a de órgão independente, desvinculado da estrutura de qualquer dos três Poderes. A nosso ver, por conseguinte, o Tribunal de Contas configura instituição estatal independente. 
materiais da jurisdição: independência, imparcialidade, igualdade processual, ampla defesa, produção plena das provas e direito a recurso." Mas, de um ponto de vista formal, ainda segundo Ricardo Lobo Torres (2000, p. 489), "não detém qualquer parcela da função jurisdicional, tendo em vista que as suas decisões não produzem a coisa julgada e podem ser revistas pelo Judiciário, ainda quando versarem sobre matéria contábil”. Para Ricardo Lobo Torres (2000, p. 490), os atos praticados pelo Tribunal de Contas têm a natureza formalmente administrativa, pois, em verdade,

[...] São pareceres, informações, relatórios, registros e decisões suscetíveis de aprovação ou de reforma pelo Legislativo, pelo Judiciário e pelo Executivo, conforme o caso. Importantíssima a função de aconselhamento dos Poderes, inclusive para a melhoria da qualidade da legislação e da jurisprudência.

As funções do Tribunal de Contas têm, portanto, caráter administrativo, mas não apenas isso, já que apresentam alguns aspectos materialmente jurisdicionais. Maria Sylvia Zanella di Pietro (1996, p. 23) defende que as decisões do Tribunal de Contas não são puramente administrativas nem tampouco jurisidicionais, estando, portanto, “em meio caminho entre uma e outra" ${ }^{\prime 196}$.

A função de fiscalização das contas segue as variações do sistema político, conforme se viu no breve histórico anteriormente apresentado. Se o Estado brasileiro qualifica-se constitucionalmente como Estado Democrático de Direito, a solidez das instituições de controle de contas é imprescindível, com o correspondente aperfeiçoamento de suas funções. Conforme Antônio Roque Citadini (1995, p. 114), um Estado sem fiscalização "[...] é Estado antidemocrático, que esconde de seus cidadãos os atos de gestão de dinheiro público". A Constituição Federal brasileira, no que é acompanhada pelas Constituições estaduais, segue tendência internacional de democratização. Nessa linha, conferiu ao Tribunal de Contas diversas atribuições de modo a fazer com que a atuação governamental seja controlada para agir no interesse da coletividade. Conforme Hélio Saul Mileski (2003, p. 213), entendendo o órgão como peça

\footnotetext{
${ }^{196}$ Para Hélio Saul Mileski (MILESKI, Helio Saul. op. cit., p. 211), o Tribunal exerce propriamente uma jurisdição administrativa: “[...] sendo o Tribunal de Contas um órgão integrante da estrutura do Estado, com função de fiscalização sobre a atividade financeira do Estado e, nessa circunstância, procedendo ao julgamento das contas daqueles que as devem prestar, não se pode negar que o mesmo exerce uma jurisdição administrativa, na medida em que possui o poder de dizer o direito, consoante as regras do ordenamento jurídico vigente, no sentido de fazer com que a Administração tenha uma atuação financeira dirigida ao interesse público, com atendimento dos princípios constitucionais da legalidade, legitimidade e economicidade, a fim de ser assegurado o bom e regular emprego dos dinheiros públicos. Esta é a função que a Constituição destinou ao Tribunal de Contas, determinando como atribuição o exercício de uma jurisdição administrativa, a qual não deve ser negada ou alterada."
} 
imprescindível aos regimes democráticos, afirma que "o Tribunal de Contas é o olho do povo, na medida em que verifica se há o regular e legal emprego dos dinheiros públicos e se a sua aplicação está direcionada ao interesse coletivo".

A par das funções emanadas pela Constituição da República ao Tribunal de Contas, evidencia-se que o órgão exerce função de auxiliar à própria sociedade, à medida que protege o patrimônio público. Esta posição tem fundamento na medida em que a Constituição alargou os instrumentos de participação popular no controle do patrimônio público e na defesa de direitos difusos. Constitui-se, assim, em órgão de defesa da res publica e de fortalecimento da governança republicana.

Isto aponta para uma relação entre as funções dos Tribunais de Contas e a efetivação de direitos fundamentais. Ricardo Lobo Torres (2000, p. 501) compreende que,

[...] cabendo ao Tribunal de Contas, de acordo com o art. 70 da Constituição Federal, a fiscalização contábil, financeira, orçamentária, operacional e patrimonial da União e das entidades da administração direta e indireta, quanto à legalidade, legitimidade e economicidade, segue-se que passa ele a exercer papel de suma importância no campo das garantias da liberdade.

Segundo Ricardo Lobo Torres (2000, 497), "Ernst Rudolf Huber atribui inicialmente ao controle de contas (Rechnungsprüfung) a característica de 'garantia institucional da Constituição' (institutionelle Verfassungsgarantie), por se basear em três princípios jurídicos: a) legalidade, que o vincula exclusivamente à lei; b) independência, que o separa do executivo; e c) ausência de lacuna, que proíbe os espaços livres de controle.

Nesse raciocínio, para Ricardo Lobo Torres (2000, p. 498),

[...] o controle da legalidade não se exaure na fiscalização formal, senão que se consubstancia no próprio controle das garantias normativas ou da segurança dos direitos fundamentais; o da economicidade tem, sobretudo, o objetivo de garantir a justiça e o direito fundamental à igualdade dos cidadãos; o da legitimidade entende com a própria fundamentação ética da atividade financeira. De modo que o estudo sobre os princípios do controle deve iniciar necessariamente pelo exame do relacionamento entre as finanças públicas e os direitos fundamentais. 
Assim, conclui, Ricardo Lobo Torres (2000, p. 502), que “o Tribunal de Contas que, como vimos, está essencialmente ligado aos direitos fundamentais, aparece na Constituição Federal de 1988 como uma das garantias institucionais da liberdade, a que o cidadão tem acesso através das garantias processuais”. Ainda reforça (2000, p. 496) que nossa Constituição, no que tange à fiscalização contábil, financeira e orçamentária, está entre as mais avançadas do mundo ${ }^{197}$.

Para melhor empreender a análise, podem ser identificados alguns aspectos, portanto, das funções de controle de contas: aqueles ligados às características formais de regularidade e respeito à lei, que conferem segurança aos direitos fundamentais, e outros referentes à eficiência e a legitimidade dos atos controlados. Trata-se de uma distinção que a Constituição Federal de 1988 trouxe ao referir, no art. 70, que o controle se exercerá quanto à legalidade, à legitimidade e à economicidade.

O Tribunal de Contas atua em defesa do princípio da legalidade ao exercer o controle da validade formal de atos necessários à execução do orçamento. Entretanto, o controle da legalidade não se esgota neste sentido estrito, já que existe também a finalidade de se garantir a segurança jurídica dos direitos fundamentais. Conforme Lobo Torres (2000, p. 506), “o controle da legalidade implica, em uma primeira acepção, o exame da adequação da gestão financeira ao orçamento e às leis materiais dos tributos e da despesa pública, o que compreende inclusive o controle dos atos normativos da Administração".

Além deste, o controle de economicidade, como já visto, é também previsto pelo artigo 70 da Constituição Federal. É neste sentido que o controle da

\footnotetext{
${ }^{197}$ Cf. Ricardo Lobo Torres (TORRES, Ricardo Lobo. Tratado de direito constitucional financeiro $e$ tributário: orçamento na Constituição. Rio de Janeiro: Renovar, 2000. v. 5, p. 497) que relata que "As Constituições da Alemanha (1949, reformulada em 1967 e 1969), da Itália (1947) e da Espanha (1978) já haviam trazido inúmeros aperfeiçoamentos no campo do controle de contas. Na década de 80 foram introduzidas modificações substanciais nas legislações de vários países (Suécia, Inglaterra, Suíça, Estados Unidos, Canadá) e ainda continua, em outros, a discussão sobre a necessidade de reforma. A perspectiva oferecida pelo direito comparado torna-se, pois, relevante para o exame do novo papel da Corte de Contas". Afirma ainda que nossa Constituição "encontrou uma primeira inspiração no art. 114 da Constituição de Bonn: '2. O Tribunal Federal de Contas, cujos membros possuem a independência judicial, controlará as contas assim como a economicidade e a legalidade da gestão orçamentária e econômica' "O autor também acredita que nosso sistema "aproxima-se, também, da Constituição da Itália: 'Art. 100: O Tribunal de Contas (Corte dei Conti) exerce o controle preventivo quanto à legitimidade dos atos do Governo, como também sobre a exatidão do balanço do Estado"”. Por fim, Ricardo Lobo Torres (Tratado de direito constitucional financeiro e tributário: orçamento na Constituição, cit., p. 497-498) ainda defende que "tem pontos de contato, igualmente, com o art. 31 da Constituição da Espanha: '2. El gasto público realizará una asignación equitativa de los recursos públicos, y su programación y ejecución responderán a los criterios de eficiencia y economia'”.
} 
Administração exercido pelo Tribunal de Contas pode também ser direcionado à verificação de adequação dos gastos e receitas com os fins a que se deveriam destinar - e esta adequação, que evita o desperdício de recursos e almeja a solução mais eficiente, exatamente no sentido que se dá à boa governança do setor público. O exercício deste controle, de outra parte, também favorece que os diversos Poderes e, principalmente, a sociedade, tenham informações suficientes sobre $\mathrm{o}$ andamento dos programas governamentais, não somente nos seus aspectos burocrático-formais, mas de efetividade de seu alcance, o que confere maior accountability e transparência ao agente executor e programador do ato e à própria Administração. O controle de economicidade é, portanto, um instrumento legítimo que a Constituição coloca à disposição da sociedade para que ela conheça melhor e, conhecendo, exija que quem determinou a execução de determinada despesa assuma as devidas responsabilidades pelos resultados efetivamente obtidos.

Neste sentido, cumpre registrar que o Regimento Interno do Tribunal de Contas da União estabelece, em seu artigo 197:

Art. 197. Diante da omissão no dever de prestar contas, da não comprovação da aplicação dos recursos repassados pela União na forma prevista no inciso VIII do art. $5^{\circ}$, da ocorrência de desfalque ou desvio de dinheiros, bens ou valores públicos, ou, ainda, da prática de qualquer ato ilegal, ilegítimo ou antieconômico de que resulte dano ao erário, a autoridade administrativa competente, sob pena de responsabilidade solidária, deverá imediatamente adotar providências com vistas à instauração de tomada de contas especial para apuração dos fatos, identificação dos responsáveis e quantificação do dano.

Verifica-se, destarte, que a inobservância do princípio da economicidade enseja a instauração de tomada de contas especial contra o agente responsável pela aplicação dos recursos públicos, sob pena de responsabilização daquele que não proceder à sua instauração.

A tomada de contas especial, portanto, consiste em procedimento próprio instaurado perante o Tribunal de Contas competente pela avaliação da gestão e da aplicação dos recursos públicos em dada esfera de atuação, e que legitima a atuação da Corte de Contas na aferição da economicidade da aplicação de tais recursos por parte do agente responsável. 
Não obstante, consoante mencionado anteriormente, a aferição da economicidade na prática de atos administrativos também pode ser realizada pelos Tribunais de Contas por meio de auditorias, em sua maioria, operacionais. Neste sentido, Homero Santos (1998, p. 24) destaca que

\begin{abstract}
Com relação às auditorias promovidas pelo Tribunal, um aspecto importante a destacar é a questão da economicidade dos atos administrativos. A nossa experiência tem revelado que fraude e corrupção no serviço público estão invariavelmente associadas a um mal ainda maior: o desperdício. $\mathrm{O}$ descaso para com a coisa pública cria um ambiente fértil para o extravio de recursos, seja ele doloso ou não. Por isso, é fundamental que os sistemas de controle saiam da esfera da simples apreciação da legalidade, da observação das formalidades, e alcancem a esfera da economicidade, da eficiência e da eficácia da ação dos administradores públicos. Impõe-se que o setor público seja cobrado por abusos de custos, por desperdícios, e não apenas por desvios comportamentais.
\end{abstract}

Com efeito, Magno Antônio da Silva (2008, p. 71-84) aduz que a preocupação com a economicidade e com a eficiência, no âmbito do governo federal, não é algo recente. Na verdade, assenta o autor, nos últimos quarenta anos, o fator custo (economicidade), ao longo da evolução do aparato legal, tem sido uma tônica.

Magno Antônio da Silva (2008, p. 71-84) ainda recorda que a Lei $n^{\circ}$ 4.320, de 17 de março de 1964, responsável pela edição de normas gerais de direito financeiro para elaboração e controle dos Orçamentos e Balanços da União, ainda vigente, estabelece, no artigo 22, inciso IV, que nos programas especiais de trabalho custeados por dotações globais, no que diz respeito às metas visadas, seja especificada a decomposição "em estimativa do custo das obras a realizar e dos serviços a prestar, acompanhadas de justificação econômica, financeira, social e administrativa”. Assim, consoante anteriormente mencionado, a economicidade constitui elemento essencial para a aferição da eficiência nos atos praticados pela Administração Pública.

Retomando a lição de Magno Antônio da Silva, ao analisar o Princípio Constitucional da Eficiência sob a ótica das Licitações Públicas, pode-se constatar facilmente o relacionamento conceitual entre eficiência e economicidade. Isto porque, segundo o autor (2008, p. 79): 
[...] tanto neste como naquele conceito prevalece, entre outras coisas, a ideia de menor custo de aquisição ou contratação, percebido como a diferença monetária entre o valor estimado ou de referência (valor mercado), base para o julgamento das propostas comerciais e o valor homologado pelo Ordenador de Despesas, ou seja, valor efetivamente contratado [...] Estritamente a eficiência se sustenta nos pilares da economicidade, da celeridade e da qualidade. Desta forma, não há eficiência na condução de um certame quando um dos pilares, por exemplo, a economicidade, é inobservado.

Reforçando a importância da fiscalização da economicidade, Adhemar Paladini Ghisi $\left(2000\right.$, p. 327-337) ${ }^{198}$ relata as práticas aplicadas por outros países, em especial no Reino Unido, o que demonstra que a defesa da coisa pública em sua maior abrangência é tendência internacional.

Com respaldo de Paulo Bugarin (1998, p. 44-45), conclui-se com segurança que, embora o princípio da economicidade não esteja expresso dentre aqueles que regem a Administração Pública, previstos no artigo 37 da Constituição, ele deve ser vetor para a boa gestão e para a interpretação das normas de Direito Financeiro. Bento José Bugarin (2000, p. 338-352), por sua vez, acrescenta, sobre a atuação do Tribunal de Contas quanto à observância ao princípio da economicidade, in verbis:

Quanto à economicidade, o Tribunal aprecia se a Administração agiu da forma mais econômica possível, atendendo a uma aceitável relação de custo-benefício. Não se quer com isso que a Administração aufira lucro pelos serviços que presta às custas do cidadão. $\mathrm{O}$ que se tem em vista é a relação custo-benefício, algumas vezes displicentemente desprezada pelo administrador em suas decisões.

\footnotetext{
198،Novamente a título exemplificativo, menciono que o National Accounting Office (NAO), Entidade de Fiscalização Superior do Reino Unido, tem como seu principal indicador a quantificação de recursos economizados em relação à quantidade de recursos despendidos pela Instituição. A meta fixada pela Instituição, que girava em torno de 7 para 1 (sete unidades monetárias economizadas para cada uma unidade monetária despendida pelo NAO), encontra-se em vias de ser reformulada, passando de 9 para 1. Registre-se, por oportuno, que esse tipo de indicador, embora possa ser considerado como "ideal" para medir o desempenho das Entidades de Fiscalização Superior que adotem os modelos de Controladorias ou Auditorias Gerais, não pode ser presumido como o mais indicado para a medição do desempenho dos Tribunais e Cortes de Contas, que possuem outras funções, além daquela simplesmente destinada a verificar a economicidade e a eficácia da aplicação dos recursos públicos. De fato, no bojo do processo democrático, os Tribunais de Contas possuem, também, a função de dizer à sociedade acerca da legalidade das despesas realizadas e da correção dos atos de uma gestão. Nesse sentido, observo que podem ocorrer atos praticados de forma contrária àquela prescrita em lei, que não tenham necessariamente conduzido ao desperdício de recursos públicos (citem-se como exemplos, no caso brasileiro, a contratação de servidores públicos sem a realização de prévio concurso público e a realização de compras sem a existência de procedimento licitatório). O trabalho dos Tribunais e Cortes de Contas destinado à detecção de atos dessa espécie não entrariam na quantificação apresentada pelo referido indicador, adotado pelo NÃO.”
} 
O papel do tribunal de Contas em relação à governança republicana fica explicitado com as palavras de Paulo Bugarin (1998:44-45), que conclui que

\begin{abstract}
Ante todo o exposto, infere-se que o princípio constitucional da economicidade da gestão de recursos e bens públicos autoriza o ente político-administrativo encarregado do específico e peculiar afazer hermenêutico constitucional - in casu, o TCU, ao exame, pari passu, dos elementos de fato informadores dos diversos processos subjetivos de tomadas de decisão de gastos/investimentos públicos vis-à-vis o conjunto objetivo dos resultados alcançáveis, qualificando-os, efetiva ou potencialmente, como ganhos ou perdas sociais, evitando-se, deste modo, a despesa pública antieconômica e a consequente perpetração do, muitas vezes irremediável, prejuízo social.
\end{abstract}

Nesta linha, o Tribunal de Contas é um dos guardiões do patrimônio público e tem papel fundamental na estrutura de governança republicana instituída a partir de 1988, pois que recebeu competência para a fiscalização do cumprimento, por parte dos gestores de recursos públicos, dos pilares que sustentam a defesa da res publica e é sob essa ótica que essa corte de contas deve aplicar o Direito Financeiro.

O mesmo se pode dizer, mas em outros termos, a respeito da fiscalização que ocorre em termos de legitimidade. Esta é uma forma de controle que, segundo Ricardo Lobo Torres (2008, p. 508), não se limita ao exame de formalidades e requisitos legais, "senão que exige também o controle de gestão, a análise de resultados e a apreciação da justiça e do custo-benefício, a ver se o cidadão realmente obtém a contrapartida do seu sacrifício econômico".

Trata-se, portanto, de uma atuação mais voltada à avaliação de performance, que se aproxima da ideia de justiça e de racionalidade no exercício da atividade financeira (Helio Mileski, 2003, p. 248).

Muito salutar é o exercício do controle de legitimidade já que, num contexto de uma nova administração do setor público, ele confere a possibilidade de que o órgão de controle verifique a adequação da atuação administrativa às suas finalidades e, assim, corrigir os comportamentos desviantes. Mais eficiente, porém, é essa atuação se chega a prevenir que tais atos lesivos ocorram, no exercício de um controle preventivo, o que será posteriormente analisado quando se verificarem as competências específicas do Tribunal de Contas. 
A moralidade administrativa também tem sido constante objeto de análise dos Tribunais de Contas, ao avaliar a regularidade na aplicação dos recursos públicos, uma vez que, consoante mencionado anteriormente, a probidade administrativa é uma espécie de moralidade administrativa qualificada e, ainda, a boa gestão de recursos públicos é inerente à prática de atos administrativos em conformidade com a moralidade administrativa.

Neste sentido, pode-se citar o entendimento de Caio Tácito (1992, 4553), que aponta ser o Tribunal de Contas um meio preventivo de "garantia da boa gestão orçamentária" e que o órgão atuará "como fiscal da exação nas obrigações financeiras assumidas pelo Poder Público”.

Ademais, destaca o autor (RDA n ${ }^{\circ}$ 190, 45-53), "na moldura da nova Constituição, a lei que a regulamenta fortalece o Tribunal de Contas na atitude de seu novo papel de pleno defensor da regular gestão dos dinheiros e bens públicos e, sobretudo, na moralidade administrativa”.

Outro aspecto relativo aos Tribunais de Contas diz respeito ao controle de eficiência, inserido na Constituição Federal a partir da Emenda Constitucional $\mathrm{n}^{\circ} 19$, conforme já visto.

Consoante anteriormente mencionado, o Tribunal de Contas da União tem se utilizado bastante de auditorias operacionais para aferição da eficiência na implantação de programas governamentais e na gestão e aplicação de recursos públicos.

Contudo, mesmo em sua atividade cotidiana de auditoria contábil e de julgamento de representações relativas a despesas públicas em geral, a ótica da eficiência tem sido constantemente utilizada pelo Tribunal de Contas da União em sua atividade de controle.

À guisa de exemplo, colacionado por Dalton Santos Morais (2004, p. 190), pode-se transcrever o seguinte trecho de julgado do Tribunal de Contas da União, em que a aplicação do princípio da eficiência foi fiscalizada: "esta aliás, tem sido a tendência moderna deste Tribunal (TCU, rel. Min. Fernando Gonçalves, DOU de 9.12.1992, p. 26.244): evitar as preocupações excessivas e cuidar mais da correta aplicação dos recursos públicos, combatendo o desperdício e a corrupção”. 
Hélio Santiago Ramos Júnior (2009, p. 148), ao tratar da importância do “governo eletrônico" para o controle pela sociedade das práticas governamentais através da rede mundial de computadores, afirma que "o princípio da eficiência está relacionado com o exercício da cidadania”. Realmente a eficiência da gestão pública é um dos pilares da governança republicana, pois que garante ao cidadão que os dinheiros públicos serão aplicados da melhor forma, trazendo os resultados planejados na execução das políticas públicas e investimentos.

Para a efetiva atuação com base nesse novo paradigma de fiscalização contábil, financeira e orçamentária, onde a performance passa a ser objeto de investigação e controle, é preciso que os tribunais de contas contem com estrutura técnica compatível com os novos desafios. Sobre as formas de controle da Administração Pública e a profissionalização de seus agentes, em um histórico do controle exercido pelo Tribunal de Contas, Bruno Wilhelm Speck (2000:152) noticia, em sua obra, que:

Uma das grandes modificações no processo de modernização do corpo administrativo ligado ao poder político foi a profissionalização dos agentes do Estado, e a sucessiva racionalização dos seus procedimentos, descritas e propagadas por autores como Wilson, Taylor e Weber no início do século. Como a meta principal do comportamento dos agentes públicos era o cumprimento de determinadas regras formais de procedimento, durante longo tempo os processos de controle também se limitavam à verificação do cumprimento dessas metas. Os dois critérios principais de averiguação eram os princípios da contabilidade e da adequação dos gastos realizados à legislação orçamentária. Esses dois critérios de controle, durante longo tempo, imprimiram um caráter uniforme à assessoria que o Tribunal de Contas presta ao parlamento. Como uma empresa de auditoria, o Tribunal revisava, como órgão independente, o balanço financeiro da União.

Ademais, as Cortes de Contas têm uma função pedagógica. A Constituição obrigou que União, Estados e Municípios mantenham escolas de governo para a formação e o aperfeiçoamento dos servidores públicos (art. 39, §2 ${ }^{\circ}$ ). Os órgãos de controle externo podem colaborar muito neste sentido. Como bem expressa Hélio Saul Mileski (2003, p. 326), para quem

Os Tribunais de Contas brasileiros, como órgãos de controle, têm o privilégio de contar com um corpo de servidores altamente qualificado e preparado para o exercício da função, com formação universitária eclética (direito, contabilidade, economia, administração, engenharia etc.) e atualização permanente em sua formação profissional e na sua atividade 
de controle, inclusive com cursos de especialização, mestrado e doutorado.

\subsubsection{A efetividade das decisões dos Tribunais de Contas}

Outra faceta importante na execução das atribuições do tribunal de Contas é a efetividade de suas decisões. De nada adiantaria que o Tribunal exercesse o controle amplo dos atos da Administração se não houvesse consequências jurídicas ao agente público que se desviou da boa gestão dos recursos financeiros do Estado. Dessa forma, é fundamental que, no julgamento das contas dos responsáveis por dinheiros, bens e valores públicos e das contas daqueles que derem causa a perda, extravio ou outra irregularidade de que resulte prejuízo ao patrimônio público, e nos demais atos de fiscalização, os Tribunais de Contas exerçam efetivamente sua competência para aplicar aos responsáveis, em caso de ilegalidade de despesa ou irregularidade de contas, as sanções previstas em lei, dentre as quais é prevista multa proporcional ao dano causado ao erário e reparação pecuniária, consoante estabelece o artigo 71, VIII, da Constituição Federal.

De fato, dispõe a Constituição Federal ${ }^{199}$ que aos Tribunais de Contas compete

julgar as contas dos administradores e demais responsáveis por
dinheiros, bens e valores públicos da administração direta e indireta,
incluídas as fundações e sociedades instituídas e mantidas pelo Poder
Público federal, e as contas daqueles que derem causa a perda, extravio
ou outra irregularidade de que resulte prejuízo ao erário público, bem
como aplicar aos responsáveis, em caso de ilegalidade de despesa ou
irregularidade de contas, as sanções previstas em lei, que estabelecerá,
entre outras cominaçôes, multa proporcional ao dano causado ao erário.

A Lei Orgânica do Tribunal de Contas da União ${ }^{200}$, ao dispor sobre a competência do referido órgão, repete a disposição constitucional em seu artigo $1^{\circ}$, I e IX.

No Estado de São Paulo, a Lei Orgânica do Tribunal de Contas estadual $^{201}$ também prevê referidas competências, em seu artigo $2^{\circ}$, III e XII. O Tribunal de

\footnotetext{
${ }^{199} \mathrm{Cf}$. artigo 71, II e VIII.

${ }^{200}$ Lei Federal no 8.443, de 16.07.1992.

${ }^{201}$ Lei Complementar Estadual no 709 , de 14.01.1993.
} 
Contas do Município de São Paulo também possui as mesmas competências que os correspondentes em âmbito federal e estadual, considerando a disposição contida no artigo 75 da Constituição Federal, que determina que as normas ali estabelecidas sejam aplicadas, no que couber, aos Tribunais de Contas estaduais e municipais remanescentes ${ }^{202}$.

$\mathrm{Na}$ esfera federal, a Lei $\mathrm{n}^{\circ} 8.443 / 92$, em seu artigo $5^{\circ}$, dispõe que a jurisdição administrativa do Tribunal de Contas da União recai sobre qualquer pessoa física, órgão ou entidade que utilize, arrecade, guarde, gerencie ou administre dinheiros, bens e valores públicos ou pelos quais a União responda, ou que, em nome desta assuma obrigações de natureza pecuniária, bem como sobre aqueles que lhe devam prestar contas ou cujos atos estejam sujeitos à sua fiscalização por expressa disposição de lei; além dos responsáveis pela aplicação de quaisquer recursos repassados pela União, mediante convênio, acordo, ajuste ou outros instrumentos congêneres, a Estado, ao Distrito Federal ou a Município, entre outras pessoas físicas e jurídicas ali elencadas ${ }^{203}$.

\footnotetext{
${ }^{202}$ Consoante entendimento do Supremo Tribunal Federal, a Constituição Federal é clara ao determinar, em seu art. 75, que as normas constitucionais que conformam o modelo federal de organização do Tribunal de Contas da União são de observância compulsória pelas Constituições dos Estados-membros (ADIN 3715MC - Relator Min. Gilmar Mendes, DJU 25.08.1006.

${ }^{203}$ Art. $5^{\circ}$ A jurisdição do Tribunal abrange:

I - qualquer pessoa física, órgão ou entidade a que se refere o inciso I do art. $1^{\circ}$ desta lei, que utilize, arrecade, guarde, gerencie ou administre dinheiros, bens e valores públicos ou pelos quais a União responda, ou que, em nome desta assuma obrigações de natureza pecuniária;

II - aqueles que derem causa a perda, extravio ou outra irregularidade de que resulte dano ao erário;

III - os dirigentes ou liquidantes das empresas encampadas ou sob intervenção ou que de qualquer modo venham a integrar, provisória ou permanentemente, o patrimônio da União ou de outra entidade pública federal;

$I V$ - os responsáveis pelas contas nacionais das empresas supranacionais de cujo capital social a União participe, de forma direta ou indireta, nos termos do tratado constitutivo.

$V$ - os responsáveis por entidades dotadas de personalidade jurídica de direito privado que recebam contribuições parafiscais e prestem serviço de interesse público ou social;

$V I$ - todos aqueles que lhe devam prestar contas ou cujos atos estejam sujeitos à sua fiscalização por expressa disposição de lei;

VII - os responsáveis pela aplicação de quaisquer recursos repassados pela União, mediante convênio, acordo, ajuste ou outros instrumentos congêneres, a Estado, ao Distrito Federal ou a Município;

VIII - os sucessores dos administradores e responsáveis a que se refere este artigo, até o limite do valor do patrimônio transferido, nos termos do inciso XLV do art. $5^{\circ}$ da Constituição Federal;

IX - os representantes da União ou do Poder Público na assembléia geral das empresas estatais e sociedades anônimas de cujo capital a União ou o Poder Público participem, solidariamente, com os membros dos conselhos fiscal e de administração, pela prática de atos de gestão ruinosa ou liberalidade à custa das respectivas sociedades.

Neste sentido, o Supremo Tribunal Federal já se pronunciou: Embora a entidade seja de direito privado, sujeita-se à fiscalização do Estado, pois recebe recursos de origem estatal, e seus dirigentes hão de prestar contas dos valores recebidos; quem gere dinheiro público ou administra bens ou interesses da comunidade deve contas ao órgão competente para a fiscalização. (MS no 21.644, Rel. Min. Néri da Silveira, DJU de 08.11.96). Natureza autárquica do Conselho Federal e dos Conselhos Regionais de Odontologia. Obrigatoriedade de prestar contas ao Tribunal de Contas da União. (MS no 21.797, Rel. Min. Carlos Velloso, DJU de 18.05.01). Ainda no mesmo sentido: MS nº 22.643, Rel. Min. Moreira Alves, DJU de 04.12.98.
} 
Destarte, é forçoso concluir que todo aquele que receba, gaste ou apenas guarde recursos públicos deve prestar contas ao Tribunal de Contas e está sujeito à sua análise e julgamento ${ }^{204}$. Cumpre, ainda, destacar que a recusa em prestar contas ao Tribunal de Contas constitui ato de improbidade administrativa ${ }^{205}$, nos termos da lei $\mathrm{n}^{\mathrm{o}} 8.429 / 92^{206} \mathrm{e}$ sujeita aquele que estiver obrigado a prestá-la às sanções previstas na referida lei.

Não obstante, a omissão quanto à prestação de contas por parte dos chefes do Poder Executivo da União ${ }^{207}$, dos Estados e do Distrito Federal ${ }^{208}$ e dos Municípios $^{209}$ constitui crime de responsabilidade e, como tal, também sujeita o infrator às sanções previstas na lei. Com efeito, a decisão a respeito da regularidade ou não das contas prestadas por gestores de recursos públicos proferida pelos Tribunais de Contas tem natureza administrativa e está sujeita à revisão junto ao Poder Judiciário ${ }^{210}$.

Judicialmente, o Supremo Tribunal Federal já reconheceu que o Tribunal de Contas, no exercício de sua atividade, detém competência para apreciar a constitucionalidade das leis e dos atos do poder público ${ }^{211} \mathrm{e}$, também, que possui legitimidade para figurar no polo passivo de mandado de segurança, mas apenas quando o ato impugnado estiver revestido de caráter impositivo ${ }^{212}$.

No julgamento das contas e para a aplicação de sanções, a emissão de decisões de caráter impositivo pelo Tribunal de Contas deve decorrer de regular processo administrativo e respeitar os princípios constitucionais da ampla defesa e do contraditório $^{213}$, com a intimação dos responsáveis para oitiva e apresentação de defesa ${ }^{214}$.

\footnotetext{
${ }^{204}$ Cf. DECOMAIN, Pedro Roberto. op. cit.

${ }^{205} \mathrm{Cf}$. artigo 11, VI da lei $\mathrm{n}^{\circ} 8.429$, de 02.06.1992.

${ }^{206}$ As sanções estão previstas no artigo 12 do referido diploma legislativo.

${ }^{207} \mathrm{Cf}$. artigo $9^{\circ}$ da lei ${ }^{\circ} 1.079$, de 10.04.1950.

${ }^{208} \mathrm{Cf}$. artigo 74 da lei $\mathrm{n}^{\mathrm{o}} 1.079 / 50$ e artigo $1^{\circ}$ da lei $\mathrm{n}^{\mathrm{o}} 7.106$, de 28.06.1986.

${ }^{209} \mathrm{Cf}$. artigo $1^{\mathrm{o}}$, VI, do Decreto-lei $\mathrm{n}^{\mathrm{o}} 201$, de 27.02.1967.

${ }^{210} \mathrm{Cf}$. JUSTEN FILHO, Marçal. Comentários à lei de licitações e contratos administrativos. 11. ed. São Paulo: Dialética, 2005. p. 653-658.

${ }^{211}$ Conforme súmula 347.

${ }^{212}$ Neste sentido, ver MS no 25.009, Relator Min. Carlos Velloso, DJU de 24.11.2004 e MS no 26.381-AgR, Relator Min. Eros Grau, DJU de 10.08.07.

${ }^{213}$ Cf. artigo 31 da Lei no 8.443/92 e artigo 51 da Lei Complementar Estadual no 709/93.

${ }^{214}$ Neste sentido, o Supremo Tribunal Federal se pronunciou da seguinte maneira: A incidência imediata das garantias constitucionais referidas dispensariam previsão legal expressa de audiência dos interessados; de qualquer modo, nada exclui os procedimentos do Tribunal de Contas da aplicação subsidiária da lei geral de processo administrativo federal (Lei 9.784/99), que assegura aos administrados, entre outros, o direito a 'ter ciência da tramitação dos processos administrativos em que tenha a condição de interessado, ter vista dos autos (art. $3^{\circ}$, II), formular alegações e apresentar documentos antes da decisão, os quais serão objeto de consideração pelo órgão competente'. A oportunidade de defesa assegurada ao interessado há de ser prévia à decisão, não lhe suprindo a falta a admissibilidade de recurso, mormente quando o único admissivel é o de reexame pelo mesmo plenário do TCU, de que emanou a decisão. (MS $\mathrm{n}^{\circ} 23.550$, Rel. Min. Sepúlveda Pertence, DJU 31.10.01).
} 
Há, ainda, previsão da possibilidade de recurso, na esfera administrativa, das decisões dos Tribunais de Contas $^{215}$. Não obstante, na falta de normas específicas, aplica-se, subsidiariamente, o Código de Processo Civil aos procedimentos dos Tribunais de Contas $^{216}$.

A Lei Orgânica do Tribunal de Contas da União prevê, em seus artigos 10 a 16, o procedimento de decisão nas tomadas e prestações de contas, determinando a citação do responsável pelas contas consideradas irregulares para apresentação de defesa ou recolhimento dos valores devidos.

Caso as contas sejam julgadas irregulares, o Tribunal de Contas da União deverá remeter cópias dos autos ao Ministério Público da União, para o ajuizamento das ações civis e penais cabíveis. Não obstante, havendo débito, o Tribunal condenará o responsável ao pagamento da dívida atualizada monetariamente, acrescida dos juros de mora devidos, podendo, ainda, aplicar-lhe multa. Não havendo débito, mas caso seja comprovado: i) omissão no dever de prestar contas, ii) prática de ato de gestão ilegal, ilegítimo, antieconômico ou infração à norma legal ou regulamentar de natureza contábil, financeira, operacional ou patrimonial, ou iii) dano ao erário decorrente de ato de gestão ilegítimo ou antieconômico, o Tribunal também deverá aplicar a multa prevista na legislação vigente.

No Estado de São Paulo, o procedimento da tomada de contas é previsto nos artigos 27 a 31 da Lei Orgânica do Tribunal de Contas Estadual e o artigo 36 da referida lei, da mesma forma que no Tribunal de Contas da União, prevê que, julgadas irregulares as contas e havendo débito, o Tribunal de Contas condenará o responsável ao recolhimento da dívida atualizada monetariamente, acrescida dos juros de mora devidos, podendo, ainda, aplicar-lhe multa. Não havendo débito, mas caso seja comprovado (i) omissão no dever de prestar contas, (ii) infração à norma legal ou regulamentar, (iii) dano ao erário decorrente de ato de gestão ilegítimo ou antieconômico ou (iv) desfalque, desvio de bens ou valores públicos, o Tribunal de Contas aplicará ao responsável a multa prevista no artigo 104 da referida lei.

A aplicação de sanções pelos Tribunais de Contas encontra previsão expressa na Constituição Federal. Além das sanções previstas em lei, consistentes, em sua grande maioria, em multa proporcional ao dano causado pelo agente punido, os Tribunais

\footnotetext{
${ }^{215} \mathrm{Cf}$. artigos 32-35 da Lei no 8.443/92 e artigos 52-55 da Lei Complementar Estadual no 709/93.

${ }^{216} \mathrm{~A}$ súmula 103 do Tribunal de Contas da União dispõe que na falta de normas legais regimentais específicas, aplicam-se, analógica e subsidiariamente, no que couber, a juízo do Tribunal de Contas da União, as disposições do Código de Processo Civil.
} 
de Contas são também responsáveis pela determinação, ao agente responsável, de recomposição material dos prejuízos causados à Administração Pública.

Em sua essência, a aplicação de sanções pelo Tribunal de Contas tem natureza administrativa. Consoante observado, compete a este órgão provocar o Ministério Público para a adoção das providências cabíveis, na esfera judicial, buscando a responsabilização dos agentes públicos.

Todavia, deve-se admitir que a determinação da recomposição do patrimônio público lesado pelo agente sancionado tem natureza de indenização decorrente de responsabilização civil. E na ausência da possibilidade de determinação, pelos Tribunais de Contas, da reparação dos danos causados ao erário, a aplicação de sanção administrativa consistente em multa, por si só, restaria inócua ${ }^{217}$.

A outorga, aos Tribunais de Contas, de competência para a aplicação de sanções decorre da necessidade de dotar suas determinações de um caráter coercitivo, de modo que sejam efetivamente adotadas. Não havendo previsão de sanção, correr-se-ia o risco das determinações de os Tribunais de Contas possuírem caráter de meras recomendações, o que anularia por completo sua eficácia prática ${ }^{218}$ e afastaria o órgão de sua missão de guardião da res publica.

Consoante mencionado, a maior parte das sanções previstas para aplicação dos Tribunais de Contas consiste em imposição de multa aos responsáveis pelas irregularidades encontradas. Com efeito, a Lei Orgânica do Tribunal de Contas da União prevê, em seus artigos 57 e 58, multa de até cem por cento do dano causado ao erário. De forma equivalente, o Tribunal de Contas do Estado de São Paulo prevê imposição de multas nos artigos 102 e 104 de sua Lei Orgânica. Não obstante, os Tribunais de Contas sob análise preveem outras duas espécies de sanções aplicáveis aos responsáveis por desvio ou malversação de dinheiro público.

\footnotetext{
${ }^{217}$ Cf DECOMAIN, Pedro Roberto. op. cit. Da mesma forma, pronunciou-se o Supremo Tribunal Federal: $a$ tomada de contas especial não consubstancia procedimento administrativo disciplinar. Tem por escopo a defesa da coisa pública, buscando o ressarcimento do dano causado ao erário. MS nº 25.880, Rel. Min. Eros Grau, DJU de 16.03.07.

${ }^{218}$ Cf. DECOMAIN, Pedro Roberto. op. cit. Neste sentido, também pronunciou-se o Supremo Tribunal Federal: não é possível, efetivamente, entender que as decisões das Cortes de Contas, no exercício de sua competência constitucional, não possuam teor de coercibilidade. Possibilidade de impor sanções, assim como a lei disciplinar. Certo está que, na hipótese de abuso no exercício dessas atribuições por agentes da fiscalização dos Tribunais de Contas, ou de desvio de poder, os sujeitos passivos das sanções impostas possuem os meios que a ordem jurídica contém para o controle de legalidade dos atos de quem quer que exerça parcela de autoridade ou poder, garantidos, a tanto, ampla defesa e o devido processo legal. (RE $\mathrm{n}^{\circ}$ 190.985, Rel. Min. Néri da Silveira, DJU de 24.08.01).
} 
O artigo 60 da Lei Orgânica do Tribunal de Contas da União prevê que, sem prejuízo das demais sanções, sempre que o Tribunal, por maioria absoluta de seus membros, considerar grave a infração cometida, o responsável ficará inabilitado, por um período que variará de cinco a oito anos, para o exercício de cargo em comissão ou função de confiança no âmbito da Administração Pública. Igualmente estabelece o artigo 106 da Lei Orgânica do Tribunal de Contas do Estado de São Paulo.

Finalmente, os Tribunais de Contas em comento preveem a declaração de inidoneidade para participar de licitação na Administração Pública, por até cinco anos, ao licitante que tiver obtido vantagem mediante fraude à licitação, consoante dispõem o artigo 46 da Lei Orgânica do Tribunal de Contas da União e o artigo 108 da Lei Orgânica do Tribunal de Contas do Estado de São Paulo.

Para análise da atuação efetiva dos Tribunais de Contas quanto à responsabilização civil de agentes públicos que tenham causado danos ao erário pelos atos cometidos, optou-se, no presente trabalho, por examinar as decisões do Tribunal de Contas da União.

O Tribunal de Contas da União tem se mostrado atuante na defesa do interesse público, com decisões bastante divulgadas na mídia. Em muitos casos, o Tribunal de Contas da União expede recomendações aos órgãos cujas contas e despesas são por ele analisadas, não só destinadas a corrigir ilegalidades, mas com intuito de evitar eventuais irregularidades na continuidade dos projetos executados. Não cabe aqui avaliação de eventual caráter político desse posicionamento, nem tampouco serão analisadas as questões de mérito envolvidas. O objetivo é apenas o de ilustrar a atuação dos tribunais de contas em relação à responsabilização dos agentes públicos.

Como exemplos de recomendações expedidas pelo Tribunal de Contas da União, podem-se citar as recomendações quanto às obras de construção da nova sede do Tribunal Superior Eleitoral ${ }^{219}$, quanto à melhor avaliação do sistema de formação de agentes de saúde junto ao Ministério da $\operatorname{Saúde}^{220}$ e quanto ao leilão da usina de Santo

\footnotetext{
${ }^{219} \mathrm{Na}$ ocasião, o TCU indicou medidas para que o TSE anule o contrato com o consórcio responsável pelas obras, mas admitiu que aquele Tribunal decida pela continuidade da obra, desde que aplique medidas saneadoras, recomendando, ainda, que as práticas consideradas eivadas de irregularidades não sejam repetidas no futuro. Informações obtidas em BLOG do Frederico Vasconcelos: uma aposta arriscada. Disponível em: <http://www1.folha.uol.com.br/folha/brasil/ult96u348138.shtml>. Acesso em: 23 nov. 2007. Uma aposta arriscada. Disponível em: <http://blogdofred.folha.blog.uol.com.br/arch2007-1118_2007-11-24.html\#2007_11-23_00_40_49-126390611-0>. Acesso em: 23 nov. 2007.

${ }^{220}$ Cf. TCU questiona ações do Ministério da Saúde no combate ao mosquito da dengue. Disponível em: <http://noticias.terra.com.br/brasil/interna/0,,OI2097890-EI306,00.html>. Acesso em: 23 nov. 2007.
} 
Antônio, no rio Madeira, que importaram na redução do preço máximo da tarifa cobrada pela energia a ser futuramente gerada ${ }^{221}$.

O Tribunal de Contas da União, além de expedir recomendações, atua de forma incisiva junto aos órgãos por ele fiscalizados, proferindo, também, determinações no limite de suas competências. Neste sentido, pode-se citar a determinação dirigida à Caixa Econômica Federal para suspender pregão eletrônico de fornecimento de cartuchos para impressoras por irregularidades no edital ${ }^{222}$, bem como a determinação para revogação, no prazo de quinze dias, da licitação para a construção de novo terminal de passageiros no aeroporto internacional de Cumbica, em São Paulo, diante da constatação de sobrepreço de inúmeros serviços ${ }^{223}$. Embora não sejam tão recentes quanto as determinações citadas anteriormente, é possível indicar também a emissão de determinações expressas quanto à realização das obras do metrô de Salvador, no Estado da Bahia, no Acórdão TCU n ${ }^{\circ}$ 370/2004 - Plenário.

Na imputação de responsabilidade aos responsáveis por desvios ou mau uso de recursos públicos, a atuação do Tribunal de Contas da União também é muito constante.

Com efeito, o Tribunal de Contas da União, no Acórdão n ${ }^{\circ} 02 / 1997^{224}$, de sua Segunda Câmara, ressaltou a profundidade da análise por ele realizada no que tange à responsabilização dos agentes públicos. Na oportunidade, foi imputada responsabilidade solidária aos representantes legais das empresas que se beneficiaram de empréstimos sem a observância das normas internas do Banco da Amazônia S.A., em conjunto com os servidores considerados responsáveis e o Tribunal determinou o recolhimento das quantias devidas a título de prejuízos causados ao Banco em questão, autorizando sua cobrança

\footnotetext{
${ }^{221}$ Cf. PREÇO máximo da energia do Madeira será de R\$122/MWh. Disponível em: <http://www1.folha.uol. com.br/folha/dinheiro/ult91u341283.shtml>. Acesso em: 15 nov. 2007 e TCU autoriza Aneel a publicar edital do leilão de Santo Antônio. Disponível em: <http://www.canalenergia. com.br/zpublisher/ materias/Busca.asp?id=61475>. Acesso em: 23 nov. 2007.

${ }^{222}$ Cf. TCU determina suspensão de pregão eletrônico da Caixa. Disponível em: <http://www1.folha.uol. com.br/folha/brasil/ult96u343496.shtml>. Acesso em: 15 nov. 2007.

${ }^{223}$ Cf. TCU barra licitação para obra em Cumbica. Disponível em: <http://www1.folha.uol. com.br/folha/cotidiano/ult95u343789.shtml>. Acesso em: 15 nov. 2007; TCU determina revogação de licitação para obras no aeroporto de Guarulhos (SP). Disponível em: $<$ http://www2.tcu.gov.br/portal/page?_pageid=33,634516\&_dad=portal\&_schema=PORTAL\&p_semdata= 1\&p_itemid=2933326\&p_back_url=\%2Fportal\%2Fpage\%3F_pageid\%3D33\%2C2294654\%26_dad\%3Dpo rtal\%26_schema\%3DPORTAL>. Acesso em: 15 nov. 2007 e Acórdão TCU no 2350/2007 - Plenário.

${ }^{224}$ Ementa do acórdão em questão, originado nos autos do processo n ${ }^{\circ}$ 001.535/1990-0: Tomada de contas especial.BASA. Concessão de empréstimo à empresa sem observância das normas internas do banco. Pagamento de comissões, a servidores e agenciadores, por parte dos mutuários. Acolhimento das alegações de defesa de um responsável e rejeição das justificativas dos demais responsáveis. Ausência de fatos novos na interposição de recurso de reconsideração contra decisão que rejeitou defesa. Contas irregulares. Débito solidário.
} 
judicial e assentou, citando a decisão $n^{\circ}$ 120/95 - Plenário, relacionada ao mesmo evento $^{225}$.

Importa frisar que, de fato, o Tribunal de Contas detém competência para analisar a legitimidade e a economicidade dos atos praticados por agentes públicos que importem receitas ou despesas à Administração Pública, ao contrário do Poder Judiciário, a quem compete única e exclusivamente a apreciação da conformidade legal destes atos. A análise das Cortes de Contas, contudo, não atinge o mérito dos atos administrativos. Todavia, a apreciação de legitimidade e economicidade dos atos, ainda que pretensamente objetiva, aproxima-se muito da análise da conveniência e oportunidade quanto à prática dos atos examinados pelo Tribunal.

Ademais, no que concerne à responsabilização dos agentes públicos, o Tribunal de Contas da União entende que sua atuação visa, precipuamente, ao ressarcimento dos prejuízos causados aos cofres públicos, com a determinação de recomposição dos danos sofridos pelo erário, o que se coaduna perfeitamente com a responsabilização civil por danos materiais, consoante já demonstrado. Já a imposição de multa, penalidade de cunho eminentemente administrativo, possui caráter acessório, o que gerou o raciocínio de que o lapso prescricional ao qual se sujeita a execução das penalidades impostas pelo Tribunal de Contas é o previsto na legislação civil e não o prazo quinquenal aplicável às dívidas passivas, consoante afirmado no Acórdão TCU n⿳亠 683/2001 - Segunda Câmara 226.

\footnotetext{
225 “....) Urge reconhecer que a natureza jurídica das decisões administrativas do TCU que condenam em débito gestor de bens ou dinheiros públicos não pode ser assimilada "in totum” àquele que apura, no juízo cível, a responsabilidade patrimonial decorrente de ato ilícito. A esta última será, inevitavelmente, agregado um plus, de natureza administrativa, vinculado ao juízo de mérito sobre a atuação do referido agente, conquanto a Constituição Federal, em seu artigo 70, "caput”, determina que o juízo a ser formulado em sede de fiscalização contábil, orçamentária, operacional e patrimonial da União e das entidades da administração direta e indireta deve subsumir-se não apenas ao princípio da legalidade, mas deverá ser igualmente considerado quanto à sua legitimidade e economicidade, aspectos que escapam ao controle efetuado pelo Poder Judiciário. (...)”

226“(... a) as dividas passivas da União, dos Estados e dos Municípios, bem assim de toda e qualquer ação contra a Fazenda federal, estadual ou municipal, sujeitam-se à prescrição quinquenal;b) as dívidas ativas da União, dos Estados e Municípios, bem assim toda e qualquer ação movida pela Fazenda federal, estadual ou municipal, regem-se pela prescrição vintenária Entendimento reiterado no Acórdão $n^{\circ}$ 05/2003 - Segunda Câmara.

Sob a égide do Código Civil de 2002, o prazo prescricional a ser considerado é o decenal. Neste sentido, Acórdãos TCU no 53/2005 - Segunda Câmara e no 1467/2005 - Plenário, este último assevera que: Outrossim, a alegada prescrição quinquenal é sem razão. Pois o presente feito não se trata de contas e de 'rombos contábeis' anteriores ao ano de 1994, mas se refere ao desvio de recursos públicos ocorridos nos dias 22 e 26/12/1994, com condenação ao ressarcimento do dano em 26/5/2004. A jurisprudência desta Casa, com base no Código Civil de 1916, é no sentido de que a cobrança dos créditos da União tenha prescrição vintenal. Contudo, em decorrência do advento do Novo Código Civil, a teor do seu art. $205 \mathrm{c} / \mathrm{c}$
} 
No exercício de sua função de responsabilizar os agentes causadores de prejuízos ao erário federal, apenas no mês de nvembro de 2007 , entre os dias $1^{\circ}$ e 23 , o Tribunal de Contas da União noticiou, em seu site na internet, trinta e duas condenações e quatro imposições de multas a responsáveis por recebimento, gestão, aplicação e prestação de contas de recursos federais, entre os quais diversos prefeitos municipais e a presidente de uma Organização Não Governamental (ONG).

Esta constatação denota a atuação do Tribunal de Contas da União voltada, efetivamente, ao ressarcimento dos cofres públicos, o que implica a responsabilização civil dos agentes cujas contas são julgadas irregulares por tal órgão.

Neste diapasão, pode-se citar a decisão que implicou a responsabilização pessoal de ex-prefeitos e ex-secretários de Saúde de Imperatriz, no Estado do Maranhão, condenando-os a devolver à União os recursos repassados pelo Fundo Nacional de Saúde (FNS) para ações do Programa de Incentivo ao Combate às Carências Nutricionais (ICCN) e também impôs multa aos responsáveis ${ }^{227}$.

E importa frisar, também, a condenação de responsáveis por omissão na prestação de contas de recursos recebidos da União, consoante anteriormente mencionado, e sua sujeição aos efeitos da revelia no âmbito do Tribunal de Contas da União. Sobre o

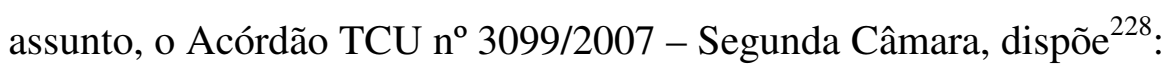

Tomada de contas especial. Omissão no dever de prestar contas. Citação. Revelia. Contas irregulares. Condenação em débito da responsável. Aplicação de multa. Autorização para cobrança judicial da dívida, caso não atendida a notificação. Remessa da documentação pertinente ao Ministério Público da União.

A omissão no dever de prestar contas de recursos públicos federais oriundos de convênio enseja o julgamento pela irregularidade das contas.

o art. 2.028, o prazo prescricional no caso em análise é de 10 anos; tendo em vista que não havia transcorrido mais da metade do tempo estabelecido na lei anterior. Ressalte-se que a prescrição decenal começa a partir do dia 11/1/2003 - data da vigência do Novo Código Civil.

${ }^{227}$ Acórdão no 3317/2007 - Primeira Câmara: Tomada de contas especial. Recursos do FNS. Não execução do objeto conveniado em sua integralidade. Irregularidade das contas. A execução parcial do convênio autoriza a rejeição das alegações de defesa e a irregularidade das contas, com a imputação do respectivo débito aos responsáveis.

${ }^{228}$ No mesmo sentido, ver Acórdão TCU no 3211/2007 - Segunda Câmara. 
Por fim, cumpre trazer à colação tema de grande relevo e polêmica, que consiste na responsabilização de advogados responsáveis pela emissão de pareceres jurídicos no âmbito dos órgãos responsáveis pela utilização dos recursos públicos, em caso de constatação de irregularidades pelos Tribunais de Contas.

O Tribunal de Contas da União, reiteradamente, manifesta entendimento no sentido de que tais profissionais são passíveis de responsabilização perante as Cortes de Contas, tanto na esfera civil quanto administrativa. No que tange à imposição de multa a tais profissionais, deve-se citar o Acórdão TCU no 190/2001 - Plenário ${ }^{229}$.

\section{O Supremo Tribunal Federal mantinha entendimento em sentido} contrário, favorável à imunidade do advogado perante o Tribunal de Contas ${ }^{230}$. Recentemente, contudo, demonstrou ter relativizado tal entendimento, não para admitir a responsabilização dos advogados signatários de pareceres em quaisquer circunstâncias, mas admitindo, sim, que tais profissionais respondam por seus pareceres nos casos em que a consulta tenha caráter vinculante ou em caso de aprovação ou ratificação de minuta de contrato ou convênios, consoante noticiado no Informativo STF n ${ }^{\circ} 475$, de 06 a 10 de agosto de $2007^{231}$ :

\footnotetext{
${ }^{229}$ Auditoria. DNER. Obras de restauração da BR-020 e BR-050 GO. Contratação irregular de empresa para rever projeto de engenharia e realizar supervisão da obra. Pareceres jurídicos autorizaram a prática das irregularidades. Razões de justificativa do ex-diretor geral rejeitadas. Razões de justificativas dos exprocuradores rejeitadas. Multa. Desconto em folha de pagamento. Determinação. Ciência ao Congresso Nacional, MPF e Ministério dos Transportes - Prática de irregularidades amparadas por parecer jurídico. Análise da matéria.

${ }^{230}$ Advogado de empresa estatal que, chamado a opinar, oferece parecer sugerindo contratação direta, sem licitação, mediante interpretação da lei das licitações. Pretensão do Tribunal de Contas da União em responsabilizar o advogado solidariamente com o administrador que decidiu pela contratação direta: impossibilidade, dado que o parecer não é ato administrativo, sendo, quando muito, ato de administração consultiva, que visa a informar, elucidar, sugerir providências administrativas a serem estabelecidas nos atos de administração ativa. Celso Antônio Bandeira de Mello, Curso de Direito Administrativo, Malheiros Ed., $13^{a}$ ed., p. 377. O advogado somente será civilmente responsável pelos danos causados a seus clientes ou a terceiros, se decorrentes de erro grave, inescusável, ou de ato ou omissão praticado com culpa, em sentido largo: Cód. Civil, art. 159; Lei 8.906/94, art. 32. (MS n 24.073, Rel. Min. Carlos Velloso, DJU de 31.10.03).

${ }^{231}$ Em conclusão de julgamento, o Tribunal, por maioria, denegou mandado de segurança impetrado contra ato do Tribunal de Contas da União - TCU que determinara a audiência de procuradores federais, para apresentarem, como responsáveis, as respectivas razões de justificativa sobre ocorrências apuradas na fiscalização de convênio firmado pelo INSS, em virtude da emissão de pareceres técnico-jurídicos no exercício profissional - v. Informativos 328, 343, 376 e 428. Entendeu-se que a aprovação ou ratificação de termo de convênio e aditivos, a teor do que dispõe o art. 38 da Lei 8.666/93, e diferentemente do que ocorre com a simples emissão de parecer opinativo, possibilita a responsabilização solidária, já que o administrador decide apoiado na manifestação do setor técnico competente (Lei 8.666/93, art. 38, parágrafo único: "As minutas de editais de licitação, bem como as dos contratos, acordos, convênios ou ajustes devem ser previamente examinadas e aprovadas por assessoria jurídica da Administração."). Considerou-se, ainda, a impossibilidade do afastamento da responsabilidade dos impetrantes em sede de mandado de segurança, ficando ressalvado, contudo, o direito de acionar o Poder Judiciário, na hipótese de virem a ser declarados responsáveis quando do encerramento do processo administrativo em curso no TCU. Vencidos os Ministros Eros Grau, Gilmar Mendes e Cármen Lúcia, que deferiam a ordem. MS 24584/DF, rel. Min. Marco Aurélio, 9.8.2007.
} 
Embora esta indicação de novo entendimento por parte do Supremo Tribunal Federal seja muito recente e ainda sujeita a diversos questionamentos em virtude de sua polêmica, pode-se acreditar que, cada vez mais, os Tribunais de Contas exercerão sua competência sancionatória em desfavor dos agentes públicos, ainda que não diretamente responsáveis pela malversação de recursos públicos, ampliando, assim, a extensão de sua competência quanto à responsabilização civil e administrativa dos agentes públicos em sentido largo.

Verifica-se que a atuação dos Tribunais de Contas tornou-se cada vez mais importante e, em decorrência disto, sua competência, mais alargada.

Assim, ao fiscalizar a aplicação de recursos públicos, o Tribunal de Contas possui competência para responsabilizar os agentes causadores de danos ao erário, seja determinando a restituição dos valores devidamente corrigidos, como aplicando multas pecuniárias, seja adicionalmente à recomposição do patrimônio público, seja isoladamente em caso de ausência de prejuízos materiais. Para a imposição de tais sanções, os Tribunais de Contas adotam procedimento próprio, assegurando aos responsáveis as garantias de ampla defesa e do contraditório.

Respondem perante os Tribunais de Contas quaisquer agentes responsáveis pelo recebimento, aplicação, gerenciamento, guarda e prestação de contas de recursos públicos, sejam eles pertencentes à esfera pública ou privada.

O Tribunal de Contas destaca-se por sua fiscalização constante em favor da proteção do patrimônio público e dirige sua atuação à reparação de quaisquer danos causados ao erário federal, o que se observa com o grande número de condenações proferidas por tal órgão, em função das mais diversas razões.

Em razão da intensificação cotidiana dos trabalhos dos Tribunais de Contas, conforme assinalado, e a indicação do Supremo Tribunal Federal da possibilidade de responsabilização de advogados públicos pela emissão de pareceres jurídicos em casos cuja irregularidade for constatada posteriormente pelos órgãos de controle externo, pode-se concluir que a atuação das Cortes de Contas, no Brasil, permanece em ascensão.

A imposição de sanções diante das irregularidades encontradas fortalece ainda mais os Tribunais de Contas no país como instituições respeitadas e até mesmo temidas pelos agentes públicos no desempenho de suas funções. 


\subsubsection{A governança republicana e os Tribunais de Contas}

Governança republicana é uma ideia indissociável da participação. Corresponde a um estágio de desempenho das atividades administrativas em que as autoridades públicas prestam contas de seu desempenho, permitindo aos diversos stakeholders (no caso, os cidadãos e a sociedade) o conhecimento do modo como são dirigidas e organizadas. Também já se disse que seus princípios fundamentais são transparência, integridade e responsabilidade em prestar contas.

Isto não é de modo algum novo. Como já visto, previa a Declaração de Direitos do Homem e do Cidadão, de 1789, que "a sociedade tem o direito de pedir conta a todo agente público por sua administração" (art. 15). Os Tribunais de Contas têm papel relevante na governança republicana e no controle social sobre a atividade financeira do Estado.

É possível verificar, no Tribunal de Contas da União, a presença que tem o tema do controle social em sua agenda institucional. Trata-se da tendência de incorporar a sociedade civil para, segundo Jane Carvalho Breder (2006, p. 195), "prevenir a corrupção e o desperdício e desenvolver, em cada cidadão, uma postura de corresponsabilidade no controle da coisa pública". As portarias $n^{\circ} .59 / 2003$ e $n^{\circ}$ 02/2006, que trazem os Planos Estratégicos do TCU, têm o objetivo de incentivar o controle social.

Há outros objetivos estratégicos, entretanto, que também estão fortemente relacionados com a governança republicana, que se referem ao poder do Tribunal de Contas de induzir comportamentos desejáveis dos diversos órgãos da Administração. Isso inclui o estreitamento das relações dos Tribunais de Contas com o Poder Legislativo e com a sociedade. Neste sentido, o incentivo do controle social pelo Tribunal de Contas passa pelo fortalecimento de institutos como a Ouvidoria do Tribunal, que se coloca como um canal permanente para a apresentação de denúncias e esclarecimento de dúvidas sobre a aplicação de recursos públicos. E da maneira mais clara, aberta e célere possível, para o atendimento do princípio constitucional da transparência.

É importante que, neste sentido, os Tribunais de Contas atuem para suprir insuficiências dos modelos de controle de outros poderes ou da sociedade, possibilitando 
que as desigualdades existentes nos níveis de informação e de capacitação técnica de cada uma dessas instâncias sejam diminuídas. ${ }^{232}$

Enxergando o Tribunal de Contas como um órgão a serviço do interesse social e da proteção à coisa pública, Jane Carvalho Breder (2006, p. 198) afirma que

[...] o fortalecimento do controle social e a consolidação da democracia participativa no Brasil têm, pela frente, muitos degraus a serem superados e uma longa jornada a ser cumprida, mormente em face da luta travada entre aqueles que buscam tirar proveito pessoal da res publica e entre aqueles que trabalham para que a transparência no seu trato e a garantia do interesse público sejam parte da cultura nacional. Cabe ao Tribunal, diante da magnitude do desafio, buscar soluções criativas que possam contribuir para o desenvolvimento da cidadania e para a consolidação de uma sociedade verdadeiramente democrática, onde o desenvolvimento econômico se harmonize com a justiça social.

Para que o papel de defesa dos interesses sociais na proteção aos recursos públicos seja efetivamente desempenhado, é preciso que os Tribunais de Contas sejam instrumentos para a accountability dos gestores públicos.

Uma das formas de tradução do termo accountability, tão recorrentes nas questões relacionadas à governança corporativa e também à governança republicana, é responsabilização por desempenho. $\mathrm{O}$ debate sobre a responsabilidade do administrador público observa, de maneira geral, seu crescimento em importância ${ }^{233}$. Observa-se, entretanto, que nos paíse que adotam os sistemas de controladoria houve mais facilidade em adequar-se a novas diretrizes do New Public Management, desenvolvendo a auditoria de desempenho e a avaliação de resultados, ao passo que em países com maior tradição no Direito Administrativo e com maior arcabouço legal há mais dificuldades na estruturação de um sistema de controle voltado à aferição do desempenho, associado às demandas sociais ${ }^{234}$.

Embora a eficiência seja reconhecida como um princípio constitucional, os mecanismos de avaliação de resultados obtidos pela Administração não são tão claros quanto aqueles que analisam a legalidade, isto é, a questão da compliance.

\footnotetext{
${ }^{232}$ Cf. RICCI, Rudá. Contradições na implementação das ações de participação. Revista Espaço Acadêmico, n. 36, maio 2004. Disponível em: <http://www.espacoacademico.com.br>. Acesso em: 10 nov. 2009.

${ }^{233} \mathrm{Cf}$. FERLIE, Ewan et al. A nova administração pública em ação. Brasília: Ed. da Universidade de Brasília, 1999.

${ }^{234}$ Cf. LIMA, Dagomar Henriques. Responsabilização por desempenho e controle externo da administração pública. Revista do TCU, n. 111, p. 36, jan./abr. 2008.
} 
Em relação às deficiências da atividade de controle no Brasil, Francisco Almeida (1999, p. 50) adverte para o fato de que

[...] inobstante o Congresso Nacional não tenha acolhido nenhuma das propostas de alteração do órgão federal de controle externo (durante a Constituinte), as mais radicais preconizavam a sua extinção, são cada vez mais visíveis e acentuados os indicadores do clamor do conjunto da sociedade exigindo mudanças nos entes públicos incumbidos de gerir e fiscalizar o patrimônio público, entre estes os Tribunais de Contas, com o propósito de assegurar que os dinheiros públicos cumpram precipuamente sua função social. Forçoso é reconhecer que a transformação é inevitável e que o resultado desta mudança deve refletir a participação proativa dos órgãos de controle. Estes devem assumir o papel de condutores desta transformação refletindo os anseios da sociedade.

Segundo Ronaldo Coutinho Garcia (2001, p. 66), algumas causas para esse descompasso podem ser identificadas: (1) a falta do exercício de um controle social, representado pela contínua exigência que os cidadãos fazem por informações do governo; (2) a agenda do controle acaba por se concentrar nos graves e numerosos casos de corrupção; (3) a falta de previsão legal clara; (4) o predomínio do Poder Executivo sobre o Poder Legislativo; (5) a insuficiência de trabalhos técnicos publicados sobre o controle de resultados e (6) a falta de uma base de conhecimento para a aferição de tais resultados.

Um primeiro comentário é que os meios de controle da legalidade, que comparam a conduta do administrador com os padrões legais, são insuficientes para a análise dos resultados obtidos por esta mesma conduta. Conferir tratamento igual a estes dois tipos de controle é um erro, pois, segundo Michael Barzelay (1997, p. 237-239), “eles diferem em pelo menos sete dimensões: as posições estratégicas adotadas pelas EFS (entidades de fiscalização superior); os critérios usados pelos auditores; as técnicas aplicadas; as habilidades necessárias aos auditores; o relacionamento entre o auditado e a EFS; as questões que se desejam responder e os incentivos para os gestores; o público interessado na informação".

De fato, as funções dos Tribunais de Contas na defesa da res publica ultrapassam, em muito, o mero exame formal e legal. De acordo com Pollitt et al. (1999, p. 105-108), 
[...] as entidades de fiscalização superior (no caso, os Tribunais de Contas) podem atuar em quatro diferentes posições estratégicas. Como representações similares do Poder Judiciário, as Cortes de Contas proferem decisões, fazem julgamentos sobre a conformidade legal dos atos de gestão pública e impõem sanções. Numa segunda posição, os Tribunais de Contas podem ser auditores contábeis, garantindo a fidedignidade das informações sobre a situação financeira e patrimonial das organizações públicas. Podem ser também pesquisadores e consultores administrativos. Numa quarta posição, ainda, estes órgãos agem como economistas ou cientistas sociais, revelando informações sobre os efeitos das políticas públicas.

De maneira geral se pode dizer, com fundamento na análise acima, que os Tribunais de Contas avançam para uma atuação mais ampla, como verdadeiros consultores administrativos. É, portanto, um arranjo bem diferente daquele referente ao controle procedimental.

Outra característica da análise de desempenho é que ela ocorre num ambiente menos previsível e padronizado do que aquele referente ao controle de legalidade. Isto porque é a criatividade e a liderança do gestor público que poderão assegurar a melhor aplicação dos recursos escassos da sociedade, de modo a obter os melhores resultados. Embora os procedimentos burocráticos ainda sejam relevantes, como forma de se garantir o cumprimento às leis, o atingimento dos fins não ocorre de forma completamente padronizável, já que envolve a evolução tecnológica, dos costumes, a circulação de informações etc. (Lima, 2008, p. 38).

Releva observar que o Tribunal de Contas não pode substituir os Poderes Executivo e Legislativo na escolha pública ou na sua realização. Por esta razão é também insuficiente que sua atuação no controle do desempenho se dê como a de um juiz que pune a corrupção ou que observa um desvio com relação ao padrão legal. O relevante deste tipo de auditoria é que ela contribua para um melhor desempenho da Administração Pública, assumindo a forma de recomendações transparentes, que sejam de acesso a todos (população, imprensa, governos etc.). Desta maneira, os Tribunais de Contas podem obter aliados estratégicos no Legislativo, na sociedade e na mídia, de modo que suas contribuições possam ser efetivamente utilizadas.

Uma posição cooperativa entre auditores e gestores, portanto, é um elemento indispensável de novos padrões de governança na relação entre entes 
fiscalizadores e executores de determinada política. Isto significa transformações com relação às auditorias tradicionais.

Essa cooperação, no interesse da sociedade, pode se dar pela transparência, à medida que o Tribunal de Contas coloque à disposição dos cidadãos, de forma sistematizada e simplificada, as informações relativas aos resultados apurados nos trabalhos de fiscalização e auditoria, inclusive com informações sobre custos, produtividade, performance, qualidade e agilidade. A ciência, por parte da sociedade, do desempenho da gestão pública irá mobilizar a Administração, não apenas para aprimoramento dos resultados, mas também para a realização de controles internos prévios, a fim de antecipar-se aos resultados dos Tribunais de Contas, corrigindo desvios e ineficiências no curso da execução de suas políticas. Conforme Dagomar Henriques Lima (2008, p. 39), "Más notícias sobre desempenho podem gerar ações saneadoras no sentido de reforçar o programa, considerando que ele seja importante para a solução de um problema social relevante. O objetivo da avaliação de desempenho é, portanto, o aprimoramento dos resultados". 


\section{CONCLUSÕES}

A gestão pública vem passando por diversas e profundas transformações ao longo dos últimos anos. De uma estrutura arcaica, lenta e distante dos cidadãos, a nova gestão pública deve, a partir de agora, pautar-se integralmente pelo interesse público e pelo efetivo atendimento das demandas da sociedade, em perfeita consonância com o espírito da Constituição Federal de 1988.

Assim como nas sociedades anônimas, onde a propriedade das ações está normalmente dissociada da administração do negócio, mas os interesses dos sócios devem ser preservados, na gestão dos recursos públicos os interesses da sociedade devem ser protegidos e ao gestor desses recursos cumpre adotar comportamento estritamente pautado pelo interesse público.

A adoção de mecanismos de governança corporativa foi a resposta encontrada nas sociedades por ações, onde a propriedade está pulverizada entre milhares de acionistas, para a proteção dos interesses dos sócios. Trata-se de uma série de instrumentos e mecanismos de controle, monitoramento, transparência e prestação de contas que atenuam os eventuais conflitos de interesse entre o administrador e o proprietário, denominados na teoria econômica de conflitos de agência.

Para a salvaguarda do interesse público na gestão financeira do Estado, a Constituição Federal estabeleceu um complexo sistema institucional, aqui denominado de governança republicana, que direciona o agente público para uma atuação transparente e eficiente, com ampla prestação de contas e respectiva responsabilização pelos atos de gestão.

Da mesma forma que na gestão privada a governança corporativa visa à proteção dos direitos de propriedade do titular das ações, na administração pública a governança republicana visa a proteger o direito do cidadão à boa gestão da res publica, direito esse que decorre do Princípio Republicano insculpido na Constituição Federal. O cidadão é o titular da coisa pública e por essa razão a gestão dos recursos públicos, angariados compulsoriamente pelo poder tributante do Estado, deve ser realizada exclusivamente em prol do interesse da sociedade. Nessa linha, os princípios constitucionais que regem a administração pública, assim como as normas de Direito 
Financeiro, devem ser aplicadas tendo como foco o perfeito funcionamento dos instrumentos de proteção da res publica.

A governança republicana deve pautar todos os ciclos da gestão financeira do Estado. Nesse sentido, tanto o planejamento orçamentário, como a efetiva execução financeira devem estar pautados pela legalidade, ética, moralidade, transparência, eficiência, economicidade e participação social. Por outro lado, a accountability e os sistemas de controle e monitoramento devem ser aptos a prevenir e corrigir desvios, além de responsabilizar os agentes públicos. De fato, a atividade de controle é elemento indispensável à concretização de uma efetiva governança republicana.

Os Tribunais de Contas exercem um importante papel na concretização da governança republicana como sistema de proteção ao interesse público. Por essa razão, a Constituição de 1988 recuperou a valorização aos Tribunais de Contas que a Constituição de 1946 dera, mas que a Constituição de 1967 retirara, transformando esses órgãos em instrumentos democráticos de fiscalização, permitindo que a sociedade conheça e aprecie os atos de seus agentes.

O fortalecimento do controle social pode encontrar forte apoio nos Tribunais de Contas, criando uma cultura de corresponsabilização da Administração e da sociedade pela gestão da coisa pública.

Ainda no sentido de aprimorar a sistemática de proteção à sociedade na gestão de recursos públicos, propõe-se a criação de conselhos de governança republicana, formados por agentes públicos e com participação da sociedade civil. Seu papel seria o de defender e acompanhar o efetivo cumprimento de todos os aspectos da governança republicana, garantindo que o cidadão tenha acesso às informações relativas à gestão financeira e à performance do governo em confronto com o planejamento estabelecido.

Por fim, sugere-se que os Tribunais de Contas, além de exercer o controle de performance, tornem disponível à sociedade o resultado de suas auditorias. Não basta a publicação no Diário Oficial. É preciso que a informação esteja à disposição do cidadão de forma simples e didática, compreensível tanto para o especialista em finanças e gestão pública, mas também para o cidadão comum. À medida que essas informações sejam repassadas ao cidadão, o gestor público tratará de desenvolver seus sistemas de controle para antecipar-se a essa divulgação. 


\section{REFERÊNCIAS BIBLIOGRÁFICAS}

ABRUCIO, Fernando Luiz. Os avanços e os dilemas do modelo pós-burocrático: a reforma da administração pública à luz da experiência internacional recente. In: BRESSER PEREIRA, Luiz Carlos; SPINK, Peter. Reforma do Estado e administração pública gerencial. 7. ed. São Paulo: FGV, 2006.

- Finanças públicas, democracia e accountability. In: BIDERMAN, Ciro; ARVATE, Paulo. Economia do setor público no Brasil. Rio de Janeiro: Elsevier; FGV, 2004.

AKDERE, Mesut; AZEVEDO; Ross E. Agency theory implications for efficient contracts in organization development. Organization Development Journal, Chesterland, v. 24, n. 2, p. 43-54, Summer 2006.

ALLARDT, Erik. Representative government in a bureaucratic age. The MIT Pres on behalf of American Academy of Arts \& Sciences. Disponível em: <http://www.jstor.org/stable/20024906>. Acesso em: 14 set. 2009.

ALMEIDA. Francisco Carlos Ribeiro de. O controle dos atos de gestão e seus fundamentos básicos. Revista do Tribunal de Contas da União, Brasília, n. 80, abr./jun. 1999.

ANAO, Australian National Audit Office. Corporate governance in commonwealth authorities and companies. Discussion Paper, 1999. Disponível em: $<$ http://www.anao.gov.au>. Acesso em: 03 jul. 2009.

ANDERSON, Charles W. The place of principles in policy analysis. The American Political Science Review, v. 73, n. 3, p. 711-723, Sep. 1979.

ANDRADE, Adriana; ROSSETTI, José Paschoal. Governança corporativa: fundamentos, desenvolvimento e tendências. 3. ed. São Paulo: Atlas, 2007.

ANDRIOLO, Leonado José. Rui Barbosa: uma visão do controle do dinheiro público. Brasília: Tribunal de Contas da União, Instituto Serzedello Corrêa, 2000.

ARAGÃO, Alexandre Santos de. O princípio da eficiência. Revista de Direito Administrativo, Rio de Janeiro, n. 237, jul./set. 2004.

ARAGÃO, Cecília Vescovi de. Burocracia, eficiência e modelos de gestão pública: um ensaio. Revista do Serviço Público, Brasília, ano 48, n. 3, set./dez. 1997. 
ARAÚJO, Edmir Netto de. Curso de direito administrativo. 4. ed. São Paulo: Saraiva, 2009.

ASSIS, Marluce Araújo; VILLA, Tereza Scatena. O controle social e a democratização da informação: um processo em construção. Revista Latino-Americana de Enfermagem, Ribeirão Preto, v. 11, n. 3, maio./jun. 2003.

ASSONI FILHO, Sérgio. Transparência fiscal e democracia. Porto Alegre: Nuria Fabris, 2009.

ÁVILA, Humberto. Estatuto do contribuinte: conteúdo e alcance. Revista Diálogo Jurídico, ano 1, v. 1, n. 3, jun. 2001.

- Teoria dos princípios: da definição à aplicação dos princípios jurídicos. São Paulo: Malheiros Ed., 2009.

BARRET, Pat. Achieving better practice corporate governance in the public sector. Austrália, 2002. Disponível em: $<$ http://anao.gov.au/uploads/documents/Achieving_Better_Practice_Corporate_Governanc e_in_the_Public_Sector1.pdf>. Acesso em: 29 jun. 2009.

. Corporate governance in the public sector context. Canberra, 2001. Disponível em:<http://www.anao.gov.au/uploads/documents/Corporate_Governance_in_the_Public_S ector_Context.pdf>. Acesso em: 29 jun. 2009.

BARROSO, Luís Roberto. Curso de direito constitucional contemporâneo. 1. ed. 3. tir. São Paulo: Saraiva, 2009.

BARZELAY, Michael. Central audit institutions and performance auditing: a comparative analysis of organizational strategies in the OECD. Governance: an international journal of policy and administration, v. 10, n. 3, p. 237-239, Jul. 1997.

BASTOS, Frederico Augusto. Competências acrescidas: economicidade e operacionalidade. In: CONGRESSO DOS TRIBUNAIS DE CONTAS DO BRASIL: OS TRIBUNAIS DE CONTAS E AS NOVAS NORMAS CONSTITUCIONAIS, 15. Anais... São Paulo: Tribunal de Contas do Estado de São Paulo, 1989.

BENTO, Leonardo Valles. Governança e governabilidade na reforma do Estado. Barueri: Manole, 2003.

BEVIR, Mark; RHODES, Rod; WELLER, Patrick. Traditions of governance: interpreting the changing role of the public sector. Public Administration, v. 81, n. 1, 2003. 
BHATTA, Gambhir. Post-NPM themes in public sector governance. State Services Commission. p. 1-16, $2003 . \quad$ Dept. $<$ http://www.ssc.govt.nz/upload/downloadable_files/Post-

NPM_Themes_In_Public_Sector_Governance.pdf>. Acesso em: 20 maio 2009.

BITTAR, Eduardo Carlos B. Moral, justiça e direito na teoria de Hans Kelsen. Disponível em: <http://www.mundodosfilosofos.com.br/bittar.htm>. Acesso em: 26 out. 2009.

BLOG do Frederico Vasconcelos: uma aposta arriscada. Disponível em: $<$ http://www1.folha.uol.com.br/folha/brasil/ult96u348138.shtml>. Acesso em: 23 nov. 2007.

BREDER, Jane Carvalho. Controle social: um modelo em construção: contribuições do Tribunal de Contas da União. In SOUSA Jr., José Geraldo (Org.). Sociedade democrática, direito público e controle externo. Brasília: Tribunal de Contas da União, 2006.

BRESSER-PEREIRA, Luiz Carlos. Cidadania e res publica: a emergência dos direitos republicanos. 1997. (ENAP - Textos para Discussão. $\mathrm{n}^{\circ} 15$ ).

Da administração pública burocrática à gerencial. In: ; SPINK, Peter. Reforma do Estado e administração pública gerencial. 7. ed. São Paulo: FGV, 2006.

Construindo o Estado republicano: democracia e reforma da gestão pública. Rio de Janeiro: FGV, 2009.

Instituições, bom Estado, e reforma da gestão pública. Revista Eletrônica sobre a reforma do Estado. Disponível em: <www.direitodoestado.com.br>. Acesso em: 05 nov. 2009.

Uma nova gestão para um novo Estado: liberal, social e republicano. Revista do Servidor Público, ano 52, n. 1, jan./mar. 2001.

- Reforma do Estado para a cidadania: a reforma gerencial brasileira na perspectiva internacional. São Paulo: Ed. 34; Brasília: ENAP, 1998.

A reforma gerencial do Estado de 1995. Revista de Administração Pública, v. 34, n. 4, p. 55-72, jul. 2000.

. Reforma da nova gestão pública: agora na agenda da América Latina, no entanto... Revista do Servidor Público, ano 53, n. 1, jan./mar. 2002.

BRIGHAM, Eugene F.; HOUSTON, Joel F. Fundamentos da moderna administração financeira. Tradução de Maria Imilda da Costa e Silva. Rio de Janeiro: Campus, 1999. 
BRUDNEY, Jeffrey L.; WRIGHT, Deil S. Revisiting administrative reform in the American States: the status of reinventing government during the 1990s. Public Administration Review, v. 62, n. 3, May/Jun. 2002.

BUGARIN, Bento José. O controle externo no Brasil: evolução, características e perspectivas. Revista do Tribunal de Contas da União, Brasília, n. 86, out./dez. 2000.

BUGARIN, Paulo Soares. O princípio constitucional da economicidade na jurisprudência do Tribunal de Contas da União. Belo Horizonte: Fórum, 2004.

Reflexões sobre o princípio constitucional da economicidade e o papel do TCU. Revista do Tribunal de Contas da União, Brasília, n. 78, out./dez. 1998.

BUTLER, Brendan. Corporate governance in the public sector. In: ANNUAL PUBLIC SECTOR SYMPOSIUM, 4. June, 1999. Disponível em: <http://www.cmc.qld.gov.au>. Acesso em: 03 jul. 2009.

CADBURY COMMITTEE. Report of the committee on the financial aspects of corporate governance. $\quad 1992 . \quad$ Disponível em: $<$ http://www.econsense.de/_CSR_INFO_POOL/CORP_GOVERNANCE/images/cadbur y_report.pdf>. Acesso em: 13 mar. 2009.

CALDAS, Eduardo de Lima. Finanças públicas e orçamento participativo: a experiência municipal brasileira. In: CONGRESO INTERNACIONAL DEL CLAD SOBRE LA REFORMA DEL ESTADO Y DE LA ADMINISTRACIÓN PÚBLICA, 5., Santo Domingo, 24 a 27 Oct. 2000.

CAMARGO, Guilherme Bueno de. A guerra fiscal à luz da Lei Complementar 101, de 4 de maio de 2000. 2005. Dissertação (Mestrado) - Faculdade de Direito, Universidade de São Paulo, São Paulo, 2005.

CAMPOS, Dejalma de. Direito financeiro e orçamentário. São Paulo: Atlas, 2001.

CANADÁ. Department of Finance. Federal Budget. Disponível em <http://www.fin.gc.ca>. Acesso em: 03 jul. 2009.

CARDOSO, Regina Luna Santos. Elaboração de indicadores de desempenho institucional e organizacional no setor público: técnicas e ferramentas. São Paulo: FPFL-CEPAM, 1999.

CARRAZZA, Roque Antonio. Curso de direito constitucional tributário. 12. ed., São Paulo: Malheiros Ed., 1999. 
CARVALHO, Antônio Gledson de. Governança corporativa no Brasil em perspectiva. Revista de Administração, São Paulo, v. 37, n. 3, p. 19-32, jul./set. 2002.

CARVALHO, Raquel Melo Urbano de. Curso de direito administrativo. Salvador: Juspodivm, 2008.

CARVAlHO FILHO, José dos Santos. Manual de direito administrativo. São Paulo: Lumen Iuris, 2008.

CASTRO, Domingos Poubel de; GARCIA, Leice Maria. Contabilidade pública no Governo Federal. São Paulo: Atlas, 2004.

CERDA, Alvaro Clarke de la. Tender offers, takeovers and corporate governance: the Latin America Corporate Governance Roundtable. São Paulo, Apr. 2000. Disponível em: <http://www.oecd.org/dataoecd/56/59/1922420.pdf>. Acesso em: 22 jul. 2009.

CHADWICK, Andrew; MAY, Christopher. Interaction between States and citizens in the age of internet: e-government in the United States, Britain and the European Union, Governance. An International Journal Policy, v. 16, n. 2, Abr. 2003.

CIPFA. Good governance standards for public services. Londres: CIPFA, 2004. Disponível em <http://www.lfhe.ac.uk/governance/govpublications/goodgov.pdf>. Acesso em: 17 out. 2009.

CITADINI, Antônio Roque. O controle externo da administração pública. São Paulo: Max Limonad, 1995.

CLAPP, Gordon P.. A new enphasis in personnel administration. Annals of the American Academy of Political and Social Science, v. 189, p. 111-118, Jan. 1937.

COASE, Ronald. The nature of the firm. Economica, [S.1.], v. 4, p. 386-405, 1937.

COMISSÃO DE VALORES MOBILIÁRIOS (CVM). Cartilha de Recomendações da CVM sobre Governança Corporativa - 2002. In: DEODATO, Alberto. Manual de ciência das finanças. São Paulo: Saraiva, 1984. Disponível em: <www.cvm.gov.br>.

CONTI, José Maurício. A autonomia financeira do Poder Judiciário. São Paulo: MP Ed., 2006.

(Coord.). Orçamentos públicos: a Lei 4.320/1964 comentada. São Paulo: Revista dos Tribunais, 2008.

CORRÊA, Izabela Moreira. Planejamento estratégico e gestão pública por resultados no processo de reforma administrativa do Estado de Minas Gerais. Revista de Administração Pública, Rio de Janeiro, v. 41, n. 3, p. 487-504, maio/jun. 2007. 
COSTA, Sylo. O quarto poder. Revista do Tribunal de Contas do Estado de Minas Gerais, ano 25, v. 4, p. 45-64, out./dez. 1997.

CPA Austrália, Excellence governance for local government. Melbourne: CPA Austrália, 2005. Disponível em: <http://www.cpaaustralia.com.au/cps/rde/xchg/SID-3F57FECB1A59978E/cpa/hs.xsl/722_11885_ENA_HTML.htm>. Acesso em: 15 out. 2009.

CRETELLA JÚNIOR, José. Curso de direito administrativo. 18. ed. Rio de Janeiro: Forense, 2003.

DAR-Government Audit Policy Directorate/The Netherlands Ministry of Finance. Government Governance: Corporate Governance in the public sector, why and how? Hague: DAR, 2000. Disponível em <http//www.minfin.nl>. Acesso em: 14 out. 2009.

DECOMAIN, Pedro Roberto. Tribunais de Contas no Brasil. São Paulo: Dialética, 2006.

DELGADO, José Augusto. A vinculação dos aspectos financeiros contemporâneos com o princípio da economicidade e os tribunais de contas. Disponível em: <http://www.ibsweb.com.br/delgado>. Acesso em: 06 out. 2009.

DEODATO, Alberto. Manual de ciência das finanças. São Paulo: Saraiva, 1984.

DI PIETRO, Maria Sylvia Zanella. Coisa julgada: aplicabilidade a decisões do Tribunal de Contas da União. Revista do TCU, 27/70/23, out./dez. 1996.

Direito administrativo. São Paulo: Atlas, 2009.

DINIZ, Eli. Governabilidade, governance e reforma do Estado: considerações sobre o novo paradigma. Revista do Serviço Público, Brasília, ano 47, v. 120, n. 2, p. 5-21, maio/ago. 1996.

DOMINGUES FILHO, João Batista. Orçamento participativo: inovação institucional? Caminhos de Geografia, v. 5, n. 11, p. 186-198, fev. 2004.

EIMICKE, William B., COHEN, Steven. Ethics and the public administrator. Annals of the American Academy of Political and Social Science, v. 537, p. 96-108, Jan. 1995.

EISENHARDT, Katheleen M. Agency theory: an assessment and review. Academy of Management Review, v. 14, n. 1, p. 57-74, 1989.

EXPOSIÇÃO DE MOTIVOS No 37, DE 18.8.2000. Aprovado em 21.8.2000. Câmara dos Deputados. Disponível em: <http://www.planalto.gov.br/ccivil_03/Codigos/codi_conduta/Cod_conduta.htm>. 
FACCIONI, Victor José. Sistema de controle interno da Administração Pública Municipal: proposta para instituir controle interno nas administrações municipais. In: ENCONTRO NACIONAL DOS TRIBUNAIS DE CONTAS. Belém, 2001. Disponível em: $<$ http://www.tce.rs.gov.br/legislacao/controle_interno/pdf/palestra.pdf>. Acesso em: 04 nov. 2009.

FALZONE, Guido. Il dovere di buona amministrazione. Milano: Giuffrè, 1953.

FAMA, Eugene; JENSEN, Michael. Separation of ownership and control. Journal of Law and Economics. [S.1.], v. 26, p. 301-327, June, 1983.

FERLIE, Ewan et al. A nova administração pública em ação. Brasília: Ed. da Universidade de Brasília, 1999.

FERNANDES, Jorge Ulisses Jacoby. Tomada de contas especial: processo e procedimento nos tribunais de contas e na Administração Pública. Brasilía: Ed. Brasília Jurídica, 1996.

2003

Tribunais de Contas no Brasil: jurisdição e competência. Belo Horizonte: Fórum,

FONSECA, Josefa Pereira da. Controle externo do gasto público sob a ótica da economicidade. 1992. Dissertação (Mestrado) - EAESP/FGV, 1992.

FORTHCOMING, Oct. 1997. Disponível em: <http://cog.kent.edu/lib/turnbull4.html>. Acesso em: 10 abr. 2009.

FRANÇA. Déclaration des Droits de l'Homme et du Citoyen de 1789. Disponível em: <http://www.assemblee-nationale.fr/histoire/dudh/1789.asp>. Acesso em: 16 out. 2009.

FRANÇA, Vladimir Rocha. Eficiência administrativa na Constituição Federal. Revista de Direito Administrativo, Rio de Janeiro, n. 220, p. 165-177, abr./jun. 2000.

FRANCO SOBRINHO, Manoel de Oliveira. O controle da moralidade administrativa. São Paulo: Saraiva, 1974.

Do princípio da moralidade administrativa. Revista de Direito Administrativo, Rio de Janeiro, n. 190, p. 247-252, out./dez. 1992.

FRANZESE, Cibele; PEDROTI, Paula Maciel. Limites e possibilidades do orçamento participativo: para além da retórica. Revista de Administração Pública, Rio de Janeiro, v. 39, n. 2, p. 207-231, mar./abr. 2005.

FURTADO, José de Ribamar Caldas. Elementos de direito financeiro. Belo Horizonte: Fórum, 2009. 
GABARDO, Emerson. Princípio constitucional da eficiência administrativa. São Paulo, Dialética, 2002.

GARCIA, Ronaldo Coutinho. Subsídios para organizar avaliações da ação governamental. Brasília: IPEA, 2001. (Texto para Discussão / Ipea, n. 776).

GASPARINI, Diógenes. Direito administrativo. São Paulo: Saraiva, 2004.

GHISI, Adhemar Paladini. Desempenho das entidades fiscalizadoras superiores e indicadores de rendimento. Revista do Tribunal de Contas da União, Brasília, n. 86, p. 327-337, out./dez. 2000.

GIACOMUZZI, José Guilherme. A moralidade administrativa: história de um conceito. Revista de Direito Administrativo, Rio de Janeiro, n. 230, p. 291-303, out./dez. 2002.

GONÇALVES, Marcus Vinicius Rios. Novo curso de direito processual civil. São Paulo: Saraiva, 2009.

GOOD Governance: the IMF's role, Washington D.C., August, 1997. Disponível em: $<$ https://www.imf.org/external/pubs/ft/exrp/govern/govern.pdf>. Acesso em: 28 out. 2009.

GOUVÊA, Gilda Portugal. Burocracia e elites burocráticas no Brasil. São Paulo: Paulicéia, 1994.

GRAHAM, John; AMOS, Bruce; PLUMPTRE, Tim. Principles for good governance in the 21st century. Policy Brief, n. 15, august/2003. Disponível em: <http://www.iog.ca/publications/policybrief15.pdf>. Acesso em: 22 ago. 2008.

GRINDLE, Merilee S. Good enough governance: poverty reduction and reform in developing countries. Governance: an international journal of policy, v. 17, n. 4, p. 525548, 2004.

Good enough governance revisited. Development Policy Review, v. 25, n. 5, p.553-574, 2007.

GUALAZZI, Eduardo Lobo Botelho. Regime jurídico dos Tribunais de Contas. São Paulo: Ed. Revista dos Tribunais, 1992.

HARADA, Kiyoshi. Responsabilidade fiscal: Lei Complementar 101/2000 comentada e legislação correlata anotada. São Paulo: Juarez de Oliveira, 2002.

HARTLEY, Jean. Innovation in governance and public services: past and present. Public Money \& Management, v. 25, n. 1, p. 27-34, Jan. 2005. 
HISTORY of the Anao. Disponível: em: $<$ ttp://www.anao.gov.au/director/aboutus/history.cfm>.

HITT, Michael A.; IRELAND, R. Duane; HOSKISSON, Robert E. Administração estratégica. Tradução José Carlos Barbosa dos Santos e Luiz Antonio Pedroso Rafael. São Paulo: Thomson, 2002.

; __ _ Strategic management: competitiveness and globalization. Cincinnati: Thomson; South-Western, 1999.

HUTHER, Jeff; SHAH, Anwar. Applying a simple measure of good governance to the debate on fiscal decentralization. Social Science Research Network, Nov. 1999. Disponível em: <http://papers.ssrn.com/sol3/papers.cfm?abstract_id=620584>. Acesso em: 20 jul. 2009.

IANNOTTA, Lucio. Princípio di legalitá e ammnistrazione di risultato. In: AMMINISTRAZIONE e legalità: fonti normativi e ordinamenti (Atti del Convegno, Macerata, 21 e 22 de maio de 1999). Milano: Giuffrè, 2000.

INSTITUTO BRASILEIRO DE GOVERNANÇA CORPORATIVA (IBGC). Código das melhores práticas de governança corporativa. 3. ed. São Paulo, 2004. Disponível em: $<$ http://www.ibgc.org.br/CodigoMelhoresPraticas.aspx>. Acesso em: 23 jun. 2009.

Uma década de governança corporativa: história do IBGC, marcos e lições da experiência. São Paulo: Saint Paul Instituto of Finance; Saraiva, 2006.

INTERNATIONAL FEDERATION OF ACCOUNTANTS - IFAC. Governance in the public sector: a governing body perspective. New York: 2001. Disponível em: $<$ http://www.ifac.org/Members/DownLoads/Study_13_Governance.pdf>. Acesso em: 24 mar. 2009.

INTERNATIONAL MONETARY FUND, Code of good practices on fiscal transparency, 2007. Disponível em: <http://www.imf.org/external/np/pp/2007/eng/051507c.pdf>. Acesso em: 01 nov. 2009.

. Code of good practices on transparency in monetary and financial policies: declaration of $1999 . \quad$ Disponível em: $<$ http://www.imf.org/external/np/mae/mft/code/index.htm\#goodtrans $>$. Acesso em: 01 nov. 2009.

Manual on fiscal transparency, Washington D.C., 2007. Disponível em: <http://www.imf.org/external/np/pp/2007/eng/101907m.pdf>. Acesso em: 01 nov. 2009. 
INTERNATIONAL ORGANIZATION OF SUPREME AUDIT INSTITUTIONS (INTOSAI). Guidelines for internal control standards for the public sector. Bruxelas: Internal Control Standards Committee, 2004.

Lima Declaration of Guidelines on Auditing Precepts. Viena, 2009.

IUDÍCIBUS, Sérgio de; MARION, José Carlos; PEREIRA, Elias. Dicionário de termos de contabilidade. 2. ed. São Paulo: Atlas, 2003.

JARACH, Dino. Finanzas públicas y derecho tributario. 2. ed. Buenos Aires: AbeledoPerrot, 1996.

JARDIM, Eduardo Ferreira. Manual de direito financeiro e tributário. 2. ed. São Paulo: Saraiva, 1994.

JENKINS, Kate. A reforma do serviço público no Reino Unido. In: BRESSER PEREIRA, Luiz Carlos; SPINK, Peter. Reforma do Estado e administração pública gerencial. 7. ed. São Paulo: FGV, 2006.

JENSEN, Michael; MECKLING, William. Theory of the firm: managerial behavior, agency costs and ownership structure. Journal of Financial Economics, [S.1.], v. 3, n. 4, p. 305-360, Oct. 1976.

JUCÁ, Francisco Pedro. Direito administrativo. In: TANAKA, Sônia Yuriko Kanashiro. Direito administrativo. São Paulo: Malheiros Ed., 2008.

JUSTEN FILHO, Marçal. Comentários à lei de licitações e contratos administrativos. 11. ed. São Paulo: Dialética, 2005.

A responsabilidade do Estado. In: FREITAS, Juarez (Org.). Responsabilidade civil do Estado. São Paulo: Malheiros Ed., 2006.

KANGIS, Peter; KAREKLIS, Peter. Governance and organizational controls in public and private banks. Corporate Governance. International Journal of Business in Society, v. 1, n. 1, p. 31-38, 2001.

KELLY, Joanne; WANNA, John. A nova gestão pública e as políticas de programação orçamentária do governo. Revista do Serviço Público, Brasília, ano 52, n. 3, jul./set. 2001.

KHAIR, Amir. Lei de Responsabilidade Fiscal: avanços e aperfeiçoamento necessários. In: MENDES, Marcos (Org.). Gasto público eficiente: 91 propostas para o desenvolvimento do Brasil. São Paulo: TopBooks, 2006. 
KOPITS, George; JIMÉNEZ, Juan Pablo; MANOEL, Alvaro. Responsabilidad fiscal a nivel subnacional: Argentina y Brasil. Disponível em: $<$ http://www.bndes.gov.br/SiteBNDES/export/sites/default/bndes_pt/Galerias/Arquivos/bf _bancos/e0001117.pdf>. Acesso em: 09 nov. 2009.

KRAMER, Fred A.. Public management in the 1980s and beyond. Implementing Governmental Change. Annals of the American Academy of Political and Social Science, v. 466, p. 91-102, mar. 1983.

LA PORTA, Rafael et al. Investor protection and corporate governance. Journal of Financial Economics. [S.1.], v. 58, p. 3-27, Oct., 2000.

Law and finance. Journal Political Economy, Chicago, v. 106, n. 6, p. 1113-1155, 1998.

LEHMANN, Erik; WARNING, Susanne; WEIGAND, Jürgen. Governance structures, multidimensional efficiency and firm profitability. Journal of Management \& Governance, Dordrecht, v. 8, n. 3, p. 279-304, 2004.

LEITE, Rosimeire Ventura. O princípio da eficiência na administração pública. Revista de Direito Administrativo, Rio de Janeiro, n. 226, p. 251-263, out./dez. 2001.

LIMA, Dagomar Henriques. Responsabilização por desempenho e controle externo da administração pública. Revista do TCU, n. 111, jan./abr. 2008.

LIMA, Gustavo Massa Ferreira. O princípio constitucional da economicidade e o controle de desempenho da Administração Pública exercido pelos Tribunais de Contas. Recife: [s.n.], 2008. Disponível em: <http://www.bdtd.ufpe.br/tedesimplificado>. Acesso em: 06 out. 2009.

LIMBERGER, Têmis. Transparência administrativa e novas tecnologias: o dever de publicidade, o direito a ser informado e o princípio democrático. Revista de Direito Administrativo, Rio de Janeiro, v. 244, p. 248-263, jan./abr. 2007.

LOPES, Alfredo Cecílio. Ensaio sobre o Tribunal de Contas. São Paulo, 1947.

LYNN JR., Laurence E.; HEINRICH, Carolyn J.; HILL, Carolyn J. Studying governance and public management: challenges and prospects. Journal of Public Administration Research and Theory, v. 10. n. 2, p. 233-261, 2000.

LYON, Patricia. Partnership for Good Governance in the 21st Century. Australian Journal of Public Administration, v. 59, n. 3, p. 87-93, Sep. 2000. 
MACÊDO, Fabrício de Queiroz. Adesão aos níveis de governança corporativa da Bovespa e a percepção de risco pelo investidor. São Paulo, 2006. Dissertação (Mestrado em Ciências Contábeis) - Faculdade de Economia, Administração e Contabilidade da Universidade de São Paulo, São Paulo, 2006.

MACHADO JR, J. Teixeira; REIS, Heraldo da Costa. A Lei 4.320 comentada e a Lei de Responsabilidade Fiscal. 31. ed. Rio de Janeiro, IBAM, 2003.

MAGALHÃES, Arthur Olivare de; SLOMSKI, Valmor. Nível de disclosure do orçamento público federal brasileiro. Revista Enfoque Reflexão Contábil, v. 26, n. 1, p. 42-53, jan./abr. 2007.

MANGANARO, Francesco. Principio di legalità e semplificazione dell'attività amministrativa: i profili critici e principi ricostruttivi. Napoli: Edizioni Scientifiche Italiane, 2000.

MARINI, Caio. Gestão pública no Brasil: temas preservados e temas emergentes na formação da agenda. In: CONGRESSO DA ASSOCIAÇÃO DE ESTUDOS BRASILEIROS BRASA - Brazilian Studies Association, 7., jun. 2004. Disponível em: <http://institutopublix.com.br/docs/brasa-brasil.pdf>. Acesso em: 01 jul. 2009.

Gestão pública: o debate contemporâneo. Salvador: FLEM, 2003. (Cadernos da Fundação Luís Eduardo Magalhães).

MARQUES, Maria da Conceição da Costa. Aplicação dos princípios da governança corporativa ao sector público. Revista de Administração Contemporânea, São Paulo, v. 11, n. 2, abr.jun. 2007.

Corporate governance in the public sector in Portugal: principles, elements and conceptual framework. Califórnia: An International Meeting of the American Accounting Association, 2005.

MARTINS, Ives Gandra. Os fundamentos constitucionais da Lei de Responsabilidade Fiscal. In: ROCHA, Valdir de Oliveira (Coord.) Aspectos relevantes da Lei de Responsabilidade Fiscal. São Paulo: Dialética, 2001. p. 165-175.

MAUSS, Cezar Volnei; SOUZA, Marco Antônio de. Gestão de custos aplicada ao setor público: modelo para mensuração e análise da eficiência e eficácia governamental. São Paulo: Atlas, 2008.

MAXIMILIANO, Carlos. Hermenêutica e aplicação do direito. Rio de Janeiro: Forense, 2008. 
MAZZILLI, Hugo Nigro. A defesa dos interesses difusos em juízo. São Paulo: Saraiva, 2009.

. Introdução ao Ministério Público. São Paulo: Saraiva, 2008.

MEDAUAR, Odete. Controle da administração pública pelo Tribunal de Contas. Revista Informação Legislativa, Brasília, ano 27, n. 108, p. 101-127 out./dez. 1990.

Direito administrativo moderno. São Paulo: Ed. Revista dos Tribunais, 2006.

MEDEIROS, Paulo Henrique Ramos; GUIMARÃES, Tomás de Aquino. Contribuições do governo eletrônico para a reforma administrativa e a governança no Brasil. Revista do Serviço Público, Brasília, v. 56, n. 4, p. 449-464, out./dez. 2005.

MEIRELLES, Hely Lopes. Direito administrativo brasileiro. São Paulo: Malheiros Ed., 2009.

MELlO, Celso Antônio Bandeira de. Curso de direito administrativo. São Paulo: Malheiros Ed., 2009.

MELLO, Gilmar Ribeiro de. Governança corporativa no Governo Federal brasileiro. São Paulo, 2006. Dissertação (Mestrado em Ciências Contábeis) - Faculdade de Economia FEA, Universidade de São Paulo, São Paulo, 2006.

MELTON, Presley W.. Administration in a Federal Government Bureau. American Political Science Association, v. 33, n. 5, p. 835-840, out. 1939.

MENDES, Gilmar Ferreira; COELHO, Inocêncio Mártires; BRANCO, Paulo Gustavo Gonet. Curso de direito constitucional. 2. ed. São Paulo: Saraiva, 2008.

MENDES, Marcos. Eficiência do gasto público: o governo focado na solução das "falhas de mercado". In: CICLO DE PALESTRAS DA ESCOLA DE GOVERNO, 1. 2008. Disponível em: <http://www.Escolade governo.gov.br/contentproducao/aplicação/search_escola/arquivos/pdf/paper_eficienciagas topublico_m mendes.pdf>. Acesso em: 06 jul. 2009.

MILESKI, Helio Saul. O controle da gestão pública. São Paulo: Ed. Revista dos Tribunais, 2003.

- Transparência do poder público e sua fiscalização. Revista Interesse Público Especial, ano 4, v. esp. 2002. Responsabilidade Fiscal.

MIRANDA, Pontes de. Comentários à Constituição de 1967, com a Emenda n. 1, de 1969. 2. ed. rev. São Paulo: Ed. Revista dos Tribunais, 1970. 
MIRANDA, Raimundo Augusto Cardoso de. Novos formatos na relação Estado e sociedade e a promoção do desenvolvimento. Adcontar, Belém, v. 5, n. 1. p. 15-34, jun. 2004.

MOISÉS, Rodrigo Gabriel. Reforma do estado e os novos modelos. Revista Eletrônica Faculdade Montes Belos, Goiás, v.1, n.2, p. 51-61, nov. 2005.

MORAIS, Dalton Santos. Os custos da atividade administrativa e o princípio da eficiência. Revista de Direito Administrativo, Rio de Janeiro, n. 237, jul./set. 2004.

MORCK, Randal. Corporations. Discussion paper - Harvard Institute of Economy Research. Cambridge: HIER, n. 2101, Jan. 2006. Disponível em: <http://www.economics.harvard.edu/journals/hier2006>. Acesso em: 14 set. 2009.

MOREIRA NETO, Diogo de Figueiredo. Administração pública gerencial. Revista Direito, Rio de Janeiro, v. 2, n. 4, jul./dez. 1998.

. Curso de direito administrativo. 15. ed. Rio de Janeiro: Forense, 2009.

Curso de direito administrativo: parte introdutória, parte geral e parte especial. Rio de Janeiro: Ed. Forense, 2005.

NAGEL, José. Normas gerais sobre fiscalização e julgamento a cargo do TCU. Revista do Tribunal de Contas da União, Brasília, n. 74, p. 31-50, out./dez. 1998.

NASSUNO, Marianne. Organização de usuários, participação na gestão e controle das organizações sociais. Revista do Serviço Público, Brasília, v. 48, n. 1, jan./abr. 1997.

NEVES, Marcelo. Entre Têmis e Leviatã: uma relação difícil. 2. ed. São Paulo: Martins Fontes, 2008.

NOGUEIRA, Ruy Barbosa. Direito tributário comparado. São Paulo: Saraiva, 1971.

NSWAO, New South Wales Audit Office. Performance audit report on corporate governance. $\quad$ Sydney, $1997 . \quad$ v. $1 . \quad$ Disponível em $<$ http://www.audit.nsw.gov.au/publications/reports/performance/1997/crpg1/crpg197.pdf>. Acesso em: 03 jul. 2009.

OKIMURA, Rodrigo Takashi. Estrutura de propriedade, governança corporativa, valor e desempenho das empresas no Brasil. São Paulo, 2003. Dissertação (Mestrado em Administração) - Faculdade de Economia, Administração e Contabilidade, Universidade de São Paulo, São paulo, 2003.

OLIVEIRA, Cristina Godoy Bernardo de; BARBOSA, Suzana Mesquita; BAGNOLI, Vicente. História do direito. Rio de Janeiro: Elsevier, 2009. 
OLIVEIRA, José Antônio de. Desafios do planejamento em políticas públicas: diferentes visões e práticas. Revista de Administração Pública, Rio de Janeiro, v. 40, n. 1, p. 273-288, mar./abr. 2006.

OLIVEIRA, Paulo Affonso Martins de. Competências acrescidas: economicidade e operacionalidade. In: CONGRESSO DOS TRIBUNAIS DE CONTAS DO BRASIL: OS TRIBUNAIS DE CONTAS E AS NOVAS NORMAS CONSTITUCIONAIS, 15. Anais... São Paulo: Tribunal de Contas do Estado de São Paulo, 1989.

OLIVEIRA, Régis Fernandes de. Curso de direito financeiro. 2. ed. São Paulo: Ed. Revista dos Tribunais, 2008.

. Responsabilidade fiscal. São Paulo: Ed. Revista dos Tribunais, 2001.

; HORVATH, Estevão. Manual de direito financeiro. São Paulo: Ed. Revista dos Tribunais, 1990.

OLSON, Marcur. The logic of collective action: public goods and the theory of groups. 2 . Ed. Massachusetts: Harvard Press, 1971.

ORGANIZAÇÃO DAS NAÇÕES UNIDAS. Benchmarking e-government: a global perspective. New York: United Nations - Division for Public Economics and Public Administration; American Society for Public Administration, 2002.

ORGANIZATION FOR ECONOMIC CO-OPERATION AND DEVELOPMENT (OECD). OECD principles of corporate governance - 2004. Disponível em: <http://www.oecd.org/dataoecd/1/42/33931148.pdf>. Acesso em: 13 jun. 2009.

OSBORNE, David; GAEBLER, Ted. Reinventando o governo: como o espírito empreendedor está transformando o setor público. Trad. de Sérgio Fernando Guarischi Bath e Ewandro Magalhães Jr. 9. ed. Brasília: MH Comunicação, 1997.

OSZLAK, Oscar. Building capacities for governance in Argentina. Asian Review of Public Administration, v. 11, n. 1, Jan./June 2000.

PAIVA, Luís Henrique. A qualidade do gasto público e a avaliação das políticas sociais: o orçamento do Ministério do Trabalho no período 2000-2006. Revista do Serviço Público, Brasília, v. 57, n. 3, jul./set. 2006.

PALLOT, June. New public management reform in New Zealand: the collective strategy phase. International Public Management Journal, v. 1, n. 1, p. 1-18, 1998. 
PARENTE, Lygia Bandeira de Mello. Participação social como instrumento para a construção da democracia: a intervenção social na administração pública brasileira. In SOUZA JUNIOR, José Geraldo de (Org.). Sociedade democrática: direito público e controle externo. Brasília: Tribunal de Contas da União, 2006. p. 203-212.

PEDREIRA, Emerson Bazilio; SANTOS, José Odálio dos. Análise da relação entre o índice de governança corporativa e o preço das ações de empresas do setor de papel e celulose. In: CONGRESSO USP CONTROLADORIA E CONTABILIDADE, 4. São Paulo. Anais. São Paulo: FEA/USP, 2004.

PEREZ, Marcos Augusto. A administração pública democrática: institutos de participação popular na administração pública. Belo Horizonte: Fórum, 2004.

PETREI, Humberto. Budget and control: reforming the public sector in Latin America. Washington: Inter-American Development Bank, 1998.

PINDYCK, R. S.; RUBINFELD, D. L. Microeconomia. Tradução de Pedro Catunda e revisão técnica de Roberto Luis Troster. São Paulo: Makron Books, 1994.

PIRES, Roberto R. Orçamento participativo e o planejamento municipal: uma análise neoinstitucional a partir do caso da Prefeitura de Belo Horizonte. Monografia, EG/FJP, Belo Horizonte, 2001.

PLATT NETO, Orion Augusto et al. Publicidade e transparência das contas públicas: obrigatoriedade e abrangência desses princípios na administração pública brasileira. Contabilidade Vista \& Revista, Belo Horizonte, v. 18, n. 1, p. 75-94, jan./mar. 2007.

POLLIT, Christopher. Managerialism and the public service. 2. ed. Oxford: Blackwell, 1993.

et al. Performance or compliance?: performance audit and public management in five countries. Oxford: Oxford University Press, 1999.

PREÇO máximo da energia do Madeira será de R\$122/MWh. Disponível em: $<$ http://www1.folha.uol. com.br/folha/dinheiro/ult91u341283.shtml>. Acesso em: 15 nov. 2007.

PRZERWORSKI, Adam. Sobre o desenho do Estado: uma perspectiva agent x principal. In: BRESSER-PEREIRA, Luiz Carlos; SPINK, Peter (Orgs.). Reforma do Estado $e$ administração pública gerencial. 7. ed. Rio de Janeiro: FGV, 2006.

QAO, Quensland Audit Office. Corporate governance: beyond compliance, a review of certain government departments. QAO Report, Brisbane, n. 7. 1999. Disponível em: <http://www.qao.qld.gov.au>. Acesso em: 03 jul. 2009. 
RAMOS, J. Baptista. Tribunal de Contas: princípio de legalidade e legalidade da despesa. Rio de Janeiro: Forense, 1980.

RAMOS JÚNIOR, Hélio Santiago. Princípio da eficiência e governo eletrônico no Brasil: o controle da administração pública pelo cidadão brasileiro. Revista Democracia Digital e Governo Eletrônico. Disponível em: $<$ http://www.buscalegis.ufsc.br/revistas/index.php/observatoriodoegov>. Acesso em: 27 nov. 2009.

RECH, Ruy Remy. Controle interno na administração pública. Diário Eletrônico do Tribunal de Contas do Estado do Rio Grande do Sul, 2003. Disponível em: $<$ http://www.tce.rs.gov.br/artigos/pdf/controle-interno-administracao-publica.pdf>. Acessado em: 30 out. 2009.

REZENDE, Denis; ULTRAMARI, Clóvis. Plano diretor e planejamento estratégico municipal: introdução teórico-conceitual. Revista de Administração Pública, Rio de Janeiro, v. 41, n. 2, mar./abr. 2007.

RIBEIRO, Antônio Magalhães. Corrupção e controle na administração pública brasileira. São Paulo: Atlas, 2004.

RIBEIRO, Renato José Brown. Administração financeira e orçamentária. Brasília: Vestcon, 2003.

RICCI, Rudá. Contradições na implementação das ações de participação. Revista Espaço Acadêmico, n. 36, maio 2004. Disponível em: <http://www.espacoacademico.com.br>. Acesso em: 10 nov. 2009.

RICHARDSON, Ruth. As reformas no setor público da Nova Zelâdia. In: BRESSERPEREIRA, Luiz Carlos; SPINK, Peter. Reforma do Estado e administração pública gerencial. 7. ed. São Paulo: FGV, 2006.

ROCHA, Fabiana; GIUBERTI, Ana Carolina. Composição do gasto público e crescimento econômico: uma avaliação macroeconômica da qualidade dos gastos dos Estados brasileiros. Economia Aplicada, São Paulo, v. 11, n. 4, p. 463-485, out./dez. 2007.

ROSS, Stephen A.; WESTERFIELD, Randolph W.; JORDAN Bradford. Princípios de administração financeira. Tradução de Antônio Zoratto Sanvicente. São Paulo: Atlas, 1998.

ROZO, José Danúbio. Relação entre mecanismos de governança corporativa e medidas de performance econômica das empresas brasileiras integrantes do Índice Brasil da Bolsa de Valores de São Paulo. 2003. Tese (Doutorado em Controladoria e Contabilidade) Faculdade de Economia, Administração e Contabilidade, Universidade de São Paulo, São Paulo, 2003. 
RUA, Maria das Graças. Desafios da administração pública brasileira: governança, autonomia, neutralidade. Revista do Serviço Público, Brasília, ano 48, n. 3, set./dez. 1997.

RYAN, Christine; NG Chew. Public sector corporate governance disclosure: an examination of annual reporting practices in Queensland. Australian Journal of Public Administration, (S.1.), v. 59, p. 11-23, June, 2000.

SANTISO, Carlos. Good governance and aid effectiveness: the world bank and conditionality. The Georgetown Public Policy Review, v. 7, n. 1, p.1-22, 2001.

SANTOS, Homero. O controle da administração pública. Revista do Tribunal de Contas da União, Brasília, n. 74, p. 17-26, out./dez. 1997.

SANTOS, Lílian Regina dos. A governança empresarial e a emergência de um novo modelo de controladoria. 2004. Dissertação (Mestrado em Controladoria e Contabilidade) - Faculdade de Economia, Administração e Contabilidade da Universidade de São Paulo, São Paulo, 2004.

SANTOS, Luciana de Almeida Araújo; LEMES, Sirlei. A Lei Sarbanes-Oxley: uma tentativa de recuperar a credibilidade do mercado de capitais norte-americano. In: CONGRESSO USP DE CONTROLADORIA E CONTABILIDADE, 4. São Paulo: USP/EAC. Disponível em <www.congressousp.fipecafi.org/artigos12004/299.pdf>. Acesso em: 13 set. 2009.

SANTOS, Márcia Walquíria Batista dos. Curso de direito administrativo econômico. São Paulo: Malheiros Ed., 2006.

SCOTT, Graham. New Zealand's Fiscal Responsibility Act. Agenda, v. 2, n. 1, 1995.

; BUSHNELL, Peter; SALLEE, Nikitin. Reform of the core public sector: New Zealand experience. Governance, v. 3, n. 2, p. 138-167, Apr. 1990.

SHIER, Adriana da Costa Ricardo. Administração pública: apontamentos sobre os modelos de gestão e tendências atuais. In: HARGER, Marcelo (Coord.). Curso de direito administrativo. Rio de Janeiro: Forense, 2007.

SHLEIFER, Andrei; VISHNY, Robert W. A survey of corporate governance. The Journal of Finance, [S.1.], n. 2, v. 52, p. 737-783, Jun. 1997.

SILVA, José Afonso da. Aplicabilidade das normas constitucionais. 6. ed. São Paulo: Malheiros Ed., 2004.

Curso de direito constitucional positivo. 31. ed. São Paulo: Ed. Revista dos Tribunais, 2008. 
SILVA, Magno Antônio da. O conceito de eficiência aplicado às licitações públicas: uma análise teórica à luz da economicidade. Revista do Tribunal de Contas da União, Brasília, n. 113, set./dez. 2008.

SILVA, Mauro Santos. Orçamento público e controle: uma primeira leitura da experiência do Fórum Popular do Orçamento do Rio de Janeiro. In: CONGRESO INTERNACIONAL DEL CLAD SOBRE LA REFORMA DEL ESTADO Y DE LA ADMINISTRACIÓN PÚBLICA, 6. Buenos Aires, Argentina, nov. 2001.

SILVEIRA, Alexandre di Miceli. Governança corporativa e estrutura de poder. São Paulo: Saint Paul Ed., 2006.

- Governança corporativa, desempenho e valor da empresa no Brasil. 2002. Dissertação (Mestrado em Administração) - Faculdade de Economia, Administração e Contabilidade da Universidade de São Paulo, São Paulo, 2002.

SLOMSKI, Valmor. Controladoria e governança na gestão pública. São Paulo: Atlas, 2005 .

Manual de contabilidade pública: um enfoque na contabilidade municipal. 2. ed. São Paulo: Atlas, 2003.

Teoria do agenciamento no Estado: uma evidenciação da distribuição de renda econômica produzida pelas entidades públicas de administração direta. 1999. Tese (Doutorado em Ciências Contábeis) - Faculdade de Economia, Administração e Contabilidade, Universidade de São Paulo, São Paulo, 1999.

; CAMARGO, Guilherme Bueno de; AMARAL FILHO, Antônio Carlos Cintra do. Apuração do resultado econômico da Procuradoria Geral do Município de São Paulo. In: ENCONTRO DA ANPAD, 32., 2008. Anais... Disponível em: $<\mathrm{http}: / /$ www.anpad.org.br/evento.php?cod_evento_edicao=38>.

; MELLO, Gilmar Ribeiro de; TAVARES FILHO, Francisco e MACÊDO, Fabrício de Queiroz. Governança corporativa e governança na gestão pública. São Paulo: Atlas, 2008 .

SMITH, Theodore M. Stimulating performance in the Indonesian bureaucracy: gap in the administrator's tool Kit. Economic Development and Cultural Change, v. 23, n. 4, p. 719738, jul. 1975.

SPECK, Bruno Wilhelm. Inovação e rotina no Tribunal de Contas da União: o papel da instituição superior de controle financeiro no sistema político-administrativo do Brasil. São Paulo: Fundação Konrad Adenauer, 2000. 
STAUB, Irineu Dario; MARTINS, Henrique Cordeiro; RODRIGUES, Suzana Braga. Governança Corporativa e Criação de valor para os acionistas: da teoria à prática, os impactos organizacionais e financeiros. Revista Economia \& Gestão - PUC Minas, Belo Horizonte, v. 2, n. 3, p. 36-55, jan./jun. 2002.

STILLMAN II, Richard J. Twenty-first century United States governance: statecraft as reform craft and the peculiar governing paradox it perpetuates. Public Administration, v. 81, n. 1, p. 19-40, 2003.

STREIT, Rosalvo Ermes; KLERING, Luís Roque. Governança pública sob a perspectiva dos sistemas complexos. São Paulo: ENAPG, 2004.

SUPREMO TRIBUNAL FEDERAL. ADPF/MC 45 - DF. Rel. Min. Celso de Mello. J. 29.4.2004. Informativo de Jurisprudência STF, Brasília, n. 345, 26-30 abr. 2004. Disponível em: <www.stf.gov.br>.

TÁCITO, Caio. A moralidade administrativa e a nova lei do Tribunal de Contas da União. Revista de Direito Administrativo, Rio de Janeiro, n. 190, out./dez. 1992.

TAVARES FILHO, Francisco. Rentabilidade e valor das companhias no Brasil: uma análise comparativa das empresas que aderiram aos níveis de governança corporativa da Bovespa. 2006. Dissertação (Mestrado em Ciências Contábeis) - Faculdade de Economia, Administração e Contabilidade, Universidade de São Paulo, São Paulo, 2006.

TCU autoriza Aneel a publicar edital do leilão de Santo Antônio. Disponível em: $<$ http://www.canalenergia.com.br/zpublisher/ materias/Busca.asp?id=61475>. Acesso em: 23 nov. 2007.

TCU barra licitação para obra em Cumbica. Disponível em: <http://www1.folha.uol. com.br/folha/cotidiano/ult95u343789.shtml>. Acesso em: 15 nov. 2007.

TCU determina revogação de licitação para obras no aeroporto de Guarulhos (SP). Disponível em: <http://www2.tcu.gov.br/portal/page?_pageid=33,634516\&_dad=portal\&_schema=PORT AL\&p_semdata=1\&p_itemid=2933326\&p_back_url=\%2Fportal\%2Fpage\%3F_pageid\%3 D33\%2C2294654\%26_dad\%3Dportal\%26_schema\%3DPORTAL>. Acesso em: 15 nov. 2007.

TCU questiona ações do Ministério da Saúde no combate ao mosquito da dengue. Disponível em: <http://noticias.terra.com.br/brasil/interna/0,,OI2097890-EI306,00.html>. Acesso em: 23 nov. 2007. 
TEIXEIRA, Vilmar Agapito. O controle da corrupção: desafios e oportunidades para o TCU. In: SOUZA JUNIOR, José Geraldo de (Org.). Sociedade democrática, direito público e controle externo. Brasília: Tribunal de Contas da União, 2006. p. 333-356.

TIMMERS, Hans. Government Governance: corporate governance in the public sector, why and how? The Netherlands Ministry of Finance. $9^{\text {th }}$ Fee Public Sector Conference. Nov. 2000. Disponível em: <http://www.ecgi.org/codes/documents/public_sector.pdf>. Acesso em: 29 jun. 2009.

TOLEDO JR, Flávio Correa; ROSSI, Sérgio Ciquera. A Lei 4.320 no contexto da Lei de Responsabilidade Fiscal. São Paulo: NDJ, 2005.

TORRES, Ricardo Lobo. Curso de direito financeiro e tributário. 12. ed. São Paulo: Renovar, 2005.

- O princípio da transparência no direito financeiro. Revista de Direito da Associação dos Procuradores do Estado do Rio de Janeiro, Rio de Janeiro, v. 8, p. 133$156,2001$.

O princípio da transparência no direito financeiro. Revista Eletrônica da AGU. Disponível em: <www.agu.gov.br>.

- Tratado de direito constitucional financeiro e tributário: orçamento na Constituição. Rio de Janeiro: Renovar, 2000. v. 5.

TRIBUNAL DE CONTAS DA UNIÃO. Manual de Auditoria de Natureza Operacional, 2000.

MMA - possibilidade de introdução de modificações em contrato administrativo já pactuado (consulta). Revista do Tribunal de Contas da União, Brasília, n. 74, p. 157-188, out./dez. 1998.

. Tribunal de Contas - controle de economicidade - auditoria operacional (processo n ${ }^{o}$ 625.282/89-2). Revista de Direito Administrativo, Rio de Janeiro, n. 177, p. 109-120.

TROSA, Sylvie. Gestão pública por resultados: quando o Estado se compromete. Tradução Maria Luíza de Carvalho. Rio de Janeiro: Revan; Brasília: ENAP, 2001.

TURNBULL, Shann. Corporate Governance: its scope, concern and theories. Corporate Governance: an international review, Blackwood, v. 5, n. 4, p. 180-205.

UMA aposta arriscada. Disponível em: <http://blogdofred.folha.blog.uol.com.br/arch200711-18_2007-11-24.html\#2007_11-23_00_40_49-126390611-0>. Acesso em: 23 nov. 2007. 
WARGAS NETO, Conrado. A Inelegibilidade e os Tribunais e Conselhos de Contas. In: SOUZA JUNIOR, José Geraldo de (Org.). Sociedade democrática, direito público e controle externo. Brasília: Tribunal de Contas da União, 2006.

WATSON, Elizabeth. Public-sector corporate governance: British Columbia's bestpractices reforms. Ivey Business Journal, Mar./Apr. 2004.

WITHERELL, William. Corporate governance: a basic foundation for the global economy. OECD Observer, Paris, n. 221-222, Summer 2000. Disponível em: <http://www.oecdobserver.org/news/fullstory.php/aid/317>. Acesso em: 22 jun. 2009.

WORLD Bank. Governance and development. Washington-DC: World Bank Publications, 1992.

YAMAMOTO, Marina Mitiyo. Teoria da divulgação aplicada ao mercado de capitais brasileiro sob a perspectiva da governança corporativa. 2005. Tese (Livre Docência) Faculdade de Economia, Administração e Contabilidade, Universidade de São Paulo, São Paulo, 2005.

; PRADO, José Estevam de Almeida. Governança e o valor das empresas. Revista

Bovespa, São Paulo out./dez. 2003. Disponível em: $<$ http://www.bovespa.com.br/InstSites/RevistaBovespa/88/Tendencias.shtml>. Acesso em: 23 jun. 2009.

ZYMLER, Benjamin. Questões de controle: controle das finanças públicas no Brasil: visão atual e prospectiva. Revista do Tribunal de Contas da União, Brasília, n. 76, abr./jun. 1998. 